UNIVERSIDADE DE SÃO PAULO INSTITUTO DE GEOCIENCIAS

\title{
ESTRATIGRAFIA E SEDIMENTAÇÃO DOS DEPÓSITOS CONTINENTAIS CENOZÓICOS DA PLANÍCIE COSTEIRA DO ESTADO DO PARANÁ
}

Oduvaldo Bessa Junior

Orientador: Prof. Dr. Kenitiro Suguio

DISSERTAÇÃO DE MESTRADO

Programa de Pós-Graduação em Geologia Sedimentar 


\section{UNIVERSIDADE DE SĀO PAULO INSTITUTO DE GEOCIENCIAS}

\section{ESTRATIGRAFIA E SEDIMENTAÇĀO DOS DEPÓSITOS CONTINENTAIS CENOZÓICOS DA PLANÍCIE COSTEIRA DO ESTADO DO PARANÁ}

Oduvaldo Bessa Junior

Orientador: Prof. Dr. Kenitiro Suguio

DISSERTAÇÃO DE MESTRADO

COMISSÃO JULGADORA

nome

Presidente:

Examinadores:
Prof. Dr. Kenitiro Suguio

Prof. Dr. Vicente José Fulfaro

Prof. Dr. Mario Sérgio Melo ass.

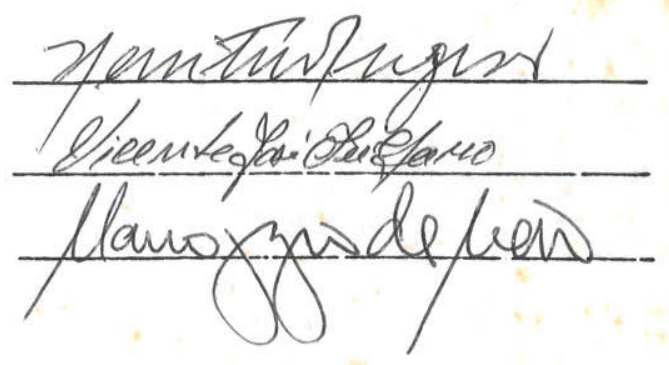

SĀO PAULO

1996 
UNIVERSIDADE DE SĀO PAULO INSTITUTO DE GEOCIENCIAS

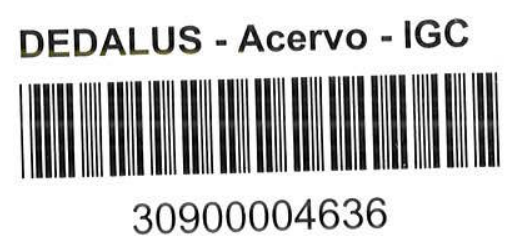

\section{ESTRATIGRAFIA E SEDIMENTAÇĀO DOS DEPÓSITOS CONTINENTAIS CENOZÓICOS DA PLANÍCIE COSTEIRA DO ESTADO DO PARANÁ}

Oduvaldo Bessa Junior

Orientador: Prof. Dr. Kenitiro Suguio

DISSERTAÇÃO DE MESTRADO

Programa de Pós-Graduação em Geologia Sedimentar

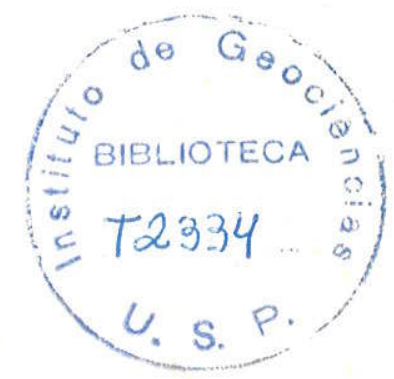

SĀO PAULO

1996 
A Oduvaldo Bessa

in memoriam 


\section{AGRADECIMENTOS}

Sinceros agradecimentos ao Professor Doutor Kenitiro Suguio pela orientação, incentivo e atenção durante a realização do trabalho.

Agradecimento especial ao Professor Doutor Rodolfo José Angulo (Dep. Geologia - UFPR), pela incentivo, sugestões e dedicação na leitura crítica do trabalho.

Ao .Professor Doutor Paulo Cesar Giannini (Dep. Gelogia - UFPR) pelas sugestões e discussões das análises granulométricas e medições de seixos.

Aos colegas do IPARDES Maria Lúcia Sugamosto, Mariane Barberi, Lucrécia Zaninelli Rocha, Luis Viveros Súnico, Renate Winz e João Jorge de Andrade pela colaboração na elaboração dos mapas.

À colega do IPARDES Stella Maris Gazziero Araujo pela colaboração na elaboração dos gráficos.

Ao Professor Doutor Jean-Pierre Ybert (ORSTOM - UFRJ) pelos estudos palinológicos.

A Jaqueline Silveira Kogut (pós-graduanda do Dep. Geologia - UFPR) pela identificação de minerais pesados.

A Maria Cristina de Souza (pós-graduanda do Dep. Geologia - UFPR) e Marcia Salete Bernini (laboratorista - CEM) pela colaboração nas análises granulométricas.

A Katia Norma Siedlek (geóloga - MINEROPAR) pelas análises de minerais de argila.

Ao Miguel Ângelo Moretti (técnico em mineração - MINEROPAR) pela colaboração nos trabalhos de campo.

A Ana Claudia de Paula Müller (pós-graduanda do Dep. Zoologia - UFPR) pelo incentivo e auxílio na elaboração do abstract.

Ao colega do IPARDES Alceu Henrique Bornancim pela revisão do abstract. 
A minha mulher Thânya Sales Jacob e a minha filha Camila Sales Jacob Bessa pelo incentivo e paciência.

E, finalmente, ao Instituto Paranaense de Desenvolvimento Econômico e Social - IPARDES, à Coordenação de Aperfeiçoamento de Pessoal de Nível Superior CAPES, à Fundação de Amparo à Pesquisa do Estado de São Paulo - FAPESP e à Minerais do Paraná S.A - MINEROPAR que, através da colaboração e apoio financeiro, possibilitaram a realização deste trabalho. 


\section{SUMÁRIO}

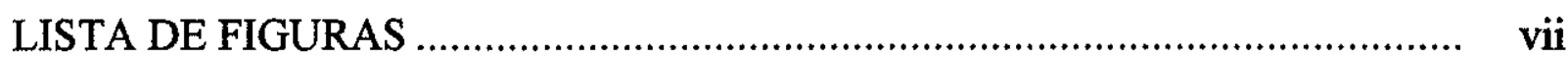

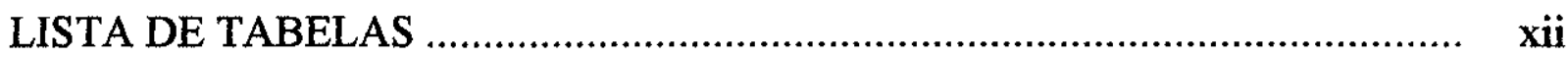

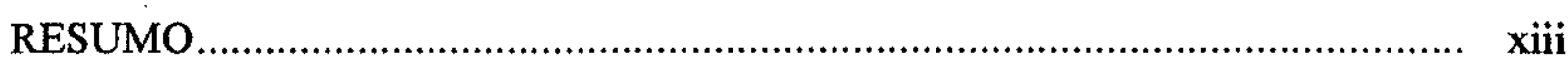

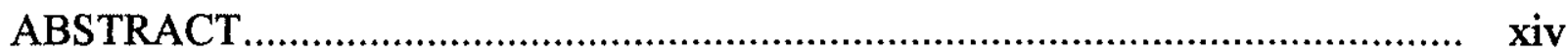

1. INTRODUÇÃ

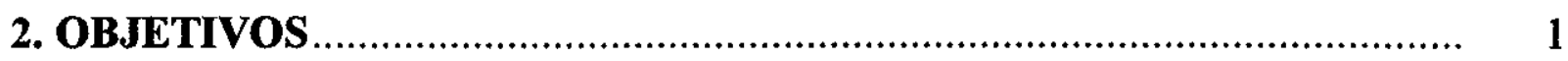

3. MATERIAIS E MÉTODOS ............................................................... 2

3.1 PESQUISA BIBLIOGRÁFICA.......................................................... 2

3.2 FOTOINTERPRETAÇÃO PRELIMINAR …….............................................. 4

3.3 TRABALHOS DE CAMPO .....................................................................

3.4 TRABALHOS DE LABORATÓRIO....................................................... 7

4. CARACTERIZAÇÃO GERAL ....................................................... 9

4.1 LOCALIZAÇÃO E ACESSO …………………....................................... 9

4.2 ASPECTOS GEOMÓRFICOS ............................................................ 11

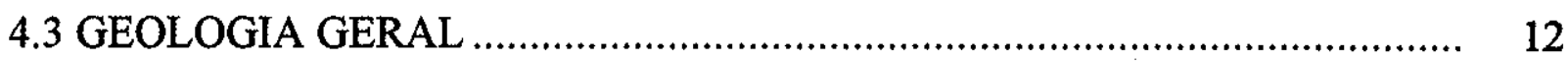

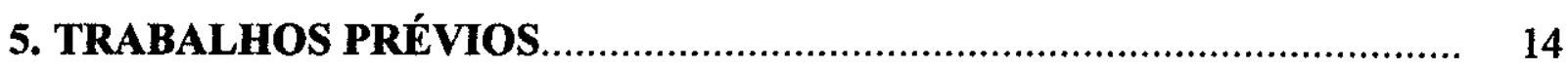

5.1 FORMAÇÃO ALEXANDRA …........................................................... 14

5.2 LEQUES E CONES ALUVIAIS QUATERNÁRIOS …............................... 17

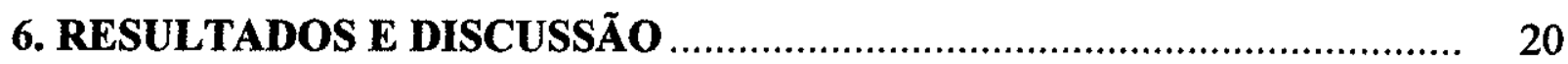

6.1 CLASSIFICAÇÃO.............................................................................. 20

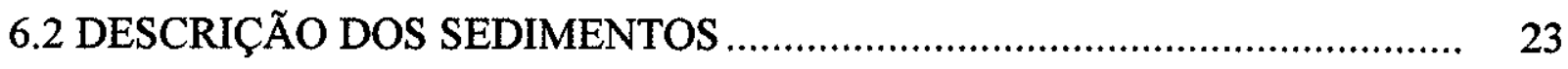

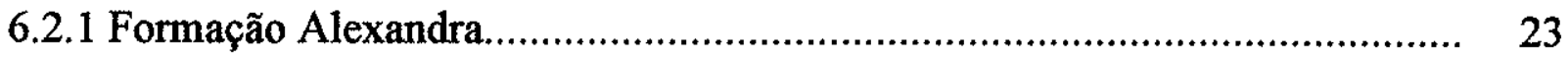

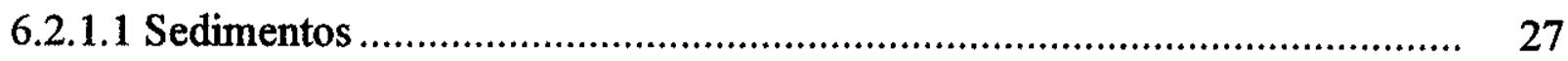

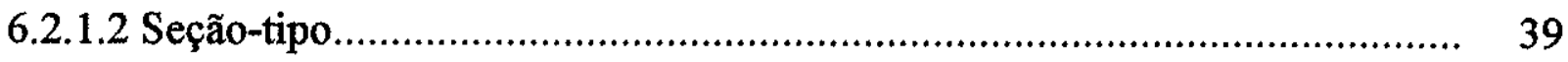

6.2.2 Leques Aluviais Quaternários.................................................................. 44

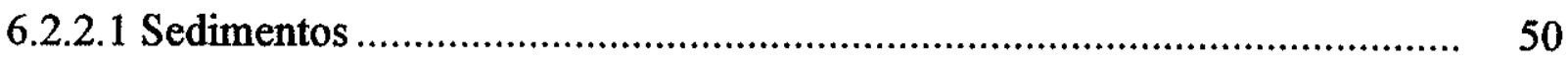

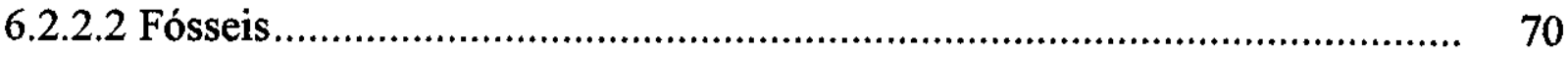




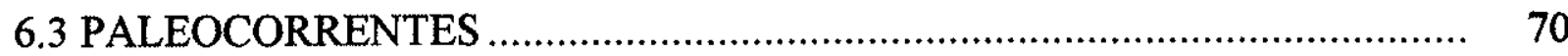

6.4 ESTUDOS SEDIMENTOLÓGICOS....................................................... 74

6.4.1 Análises Granulométricas ...................................................................... 74

6.4.1.1 Parâmetros de Folk \& Ward .................................................................... 75

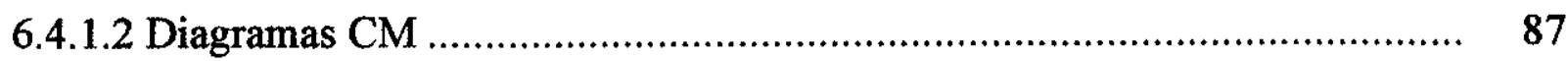

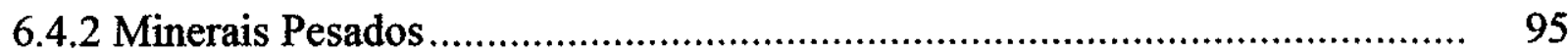

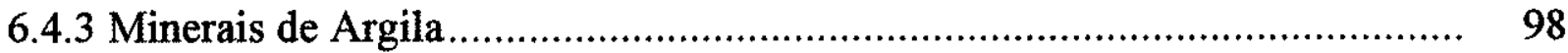

6.5 INTERPRETAÇÃO SEDIMENTOLÓGICA E ESTRATIGRÁFICA ............. 100

6.5.1 Formação Alexandra.............................................................................. 100

6.5.1.1 Ambiente Deposicional e Paleoclima....................................................... 100

6.5.1.2 Relações Estratigráficas....................................................................... 102

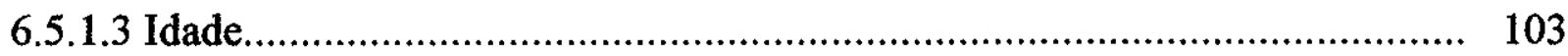

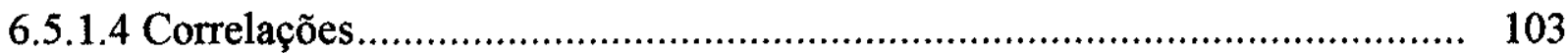

6.5.2 Leques Aluviais Quaternários............................................................... 104

6.5.2.1 Ambiente Deposicional e Paleoclima.................................................... 104

6.5.2.2 Relações Estratigráficas .................................................................... 107

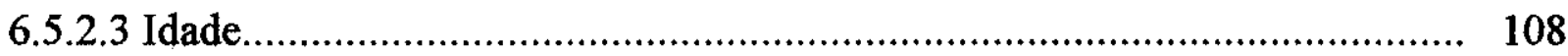

6.5.2.4 Correlações.............................................................................................. 109

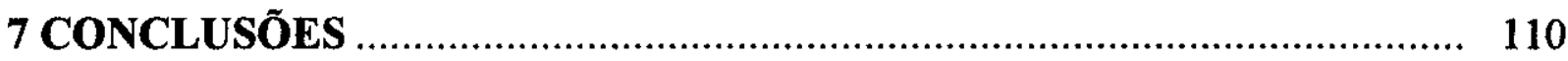

7.1 EVOLUÇÃO PALEOGEOGRÁFICA …................................................ 113

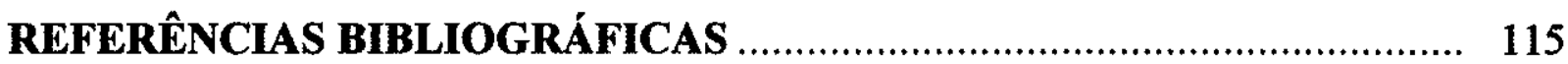

ANEXO 1 RELAÇÃO DAS AMOSTRAS COLETADAS E RESULTADOS DAS ANÁLISES GRANULOMÉTRICAS ................... 120

ANEXO 2 ANÁLISES PALINOLÓGICAS.............................................. 129

ANEXO 3 MEDIDAS DE ORIENTAÇÃO E CARACTERÍSTICAS MORFOSCÓPICAS DOS SEIXOS ..................................... 136 


\section{LISTA DE FIGURAS}

Figura 1: Detalhe do aparelho utilizado para medição de seixos....................................6

Figura 2: Mapa de localização e acesso à área pesquisada.......................................10

Figura 3: Seção-tipo da Formação Alexandra.............................................................16

Figura 4: Mapa de articulação dos mapas geológicos...................................................24

Figura 5: Mapa geológico para os sedimentos continentais cenozóicos

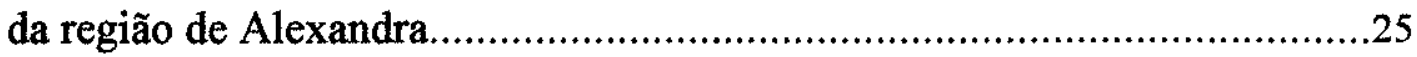

Figura 6: Mapa geológico para os sedimentos continentais cenozóicos da região de Guaraqueçaba.

Figura 7: Areia arcoziana intercalada com camadas de lamas da Formação Alexandra.

Figura 8: Lama da Formação Alexandra com marcas de tubos....................................28

Figura 9: Topo de camada de lama da Formação Alexandra......................................29

Figura 10: Areia arcoziana da Formação Alexandra contendo estratificações cruzadas tabulares e de escavação e preenchimento..

Figura 11: Camadas de areia arcoziana e lamas da Formação Alexandra apresentando estruturas de boudinage sedimentar.

Figura 12: Depósito com ocorrência de rudáceos e areia arcosiana da Formação Alexandra sobre granito alterado.

Figura 13: Depósito de cascalho sustentado por clastos da Formação Alexandra apresentando imbricações e estratificações cruzadas tabulares........35

Figura 14: Depósito de cascalho sustentado por clastos da Formação Alexandra, contendo lente de lama.

Figura 15: Depósitos da Formação Alexandra compostos de areias arcozianas e lamas intercaladas com cascalhos sustentados.

Figura 16: Depósitos de areia arcoziana e lama da Formação Alexandra, apresentando lobos de areia em meio à lama...........................................38

Figura 17: Detalhe da figura anterior, mostrando lobo arenoso sobre a lama...............39

Figura 18: Esquema das camadas de topo da seção-tipo da Formação Alexandra.......40

Figura 19: Camada do topo da seção-tipo da Formação Alexandra, apresentando estrutura de escavação e preenchimento e pelotas de argila.

Figura 20: Camada de areia arcoziana depositada em paleocanal na camada de lama 
Figura 21: Depósitos intercalados de lamas e areias arcozianas da Formação Alexandra.

Figura 22: Depósitos sedimentares da Formação Alexandra, com camadas de lamas e areias arcozianas intercaladas com cascalhos sustentados por clastos.

Figura 23: Mapa geológico do leque aluvial Colônia Pereira. .45

Figura 24: Mapa geológico dos leques aluviais Camabará/Cachoeirinha.....................46

Figura 25: Mapa geológico do leque aluvial Cubatão................................................47

Figura 26: Mapa geológico dos leques aluviais Brejatuba e Pombas..........................48

Figura 27: Mapa geológico do leque aluvial Morretes...........................................49

Figura 28: Depósito de areia arcoziana do leque aluvial Colônia Pereira apresentando estrutura de escavação e e preenchimento com estratificações cruzadas e plano-paralelas..

Figura 29: Depósito de areia arcoziana do leque aluvial Colônia Pereira apresentando estratificações plano-paralelas sub-horizontais

Figura 30: Bloco de lama deformada no meio de areia arcoziana do leque aluvial Colônia Pereira.

Figura 31: Depósito de lama do leque aluvial Colônia Pereira apresentando paleocanal preenchido com areia arcoziana. .54

Figura 32: Depósito de cascalho sustentado por matriz do leque aluvial Colônia Pereira

Figura 33: Depósito de cascalho sustentado por clastos do leque aluvial Colônia Pereira com estruturas de escavação e preenchimento e granocrescência ascendente.

Figura 34: Depósito de silte arenoso contendo vegetais fósseis do leque aluvial Colônia Pereira. .56

Figura 35: Afloramento característico do leque aluvial Colônia Pereira .57

Figura 36: Esquema dos depósitos sedimentares do leque aluvial Colônia Pereira.

Figura 37: Detalhe da granocrescência ascendente em areia arcoziana do leque aluvial Cambará/Cachoeirinha.

Figura 38: Detalhe de pelotas de argila em areia arcoziana do leque aluvial Cambará/Cachoeirinha (ponto 23.1.92-01).

Figura 39: Depósitos de cascalhos sustentados por matriz do leque aluvial Cambará/Cachoeirinha

Figura 40: Esquema apresentando as camadas sedimentares do leque aluvial Cambará/Cachoeirinha. 
Figura 41: Depósito de areia arcoziana do leque aluvial Cubatão, apresentando estratificações cruzadas e estruturas de escavação e preenchimento.

Figura 42: Depósito de cascalho sustentado por clastos do leque aluvial Morretes, apresentando imbricações de seixos e estratificações cruzadas.

Figura 43: Sedimentos do leque aluvial Morretes, apresentando paleocanal na base do conglomerado.

Figura 44: Cascalho sustentado por matriz do leque aluvial Caovi, apresentando clastos alterados de granito que se confundem com a matriz.

Figura 45: Blocos de cascalhos sustentados por matriz que ocorrem na superficie do leque aluvial Brejatuba.

Figura 46: Detalhe de lama encontrada no leque aluvial Brejatuba, mostrando grânulos e seixos de fragmentos líticos.

Figura 47: Camada de areia arcoziana sobre lama no leque aluvial Brejatuba

Figura 48: Diagrama de roseta para medições de seixos da Formação Alexandra.

Figura 49: Diagrama de roseta para medições de seixos da Formação Alexandra

Figura 50: Diagrama de roseta para medições de seixos do leque aluvial Morretes 72

Figura 51: Frequências porcentuais médias das classes texturais por unidade estratigráfica.

Figura 52: Valores médios dos parâmetros de Folk \& Ward (1957) por unidades estratigráficas

Figura 53: Parâmetros estatísticos médios de Folk \& Ward (1957) da Formação Alexandra para diâmetro médio $x$ mediana de amostras da região de Alexandra.

Figura 54: Parâmetros estatísticos médios de Folk \& Ward (1957) da Formação Alexandra para mediana $\mathrm{x}$ assimetria de amostras da região de Alexandra

Figura 55: Parâmetros estatísticos médios de Folk \& Ward (1957) da Formação Alexandra para diâmetro médio $\mathrm{x}$ mediana de amostras da região de Guaraqueçaba.

Figura 56: Parâmetros estatísticos médios de Folk \& Ward (1957) da Formação Alexandra para mediana $\mathrm{x}$ assimetria de amostras da região de Guaraqueçaba. 
Figura 57: Parâmetros estatísticos médios de Folk \& Ward (1957) da Formação Alexandra para diâmetro médio $\mathrm{x}$ mediana para todas as amostras analisadas

Figura 58: Parâmetros estatísticos médios de Folk \& Ward (1957) da Formação Alexandra para mediana $\mathrm{x}$ assimetria de todas as amostras analisadas.

Figura 59: Parâmetros estatísticos médios de Folk \& Ward (1957) do leque aluvial Colônia Pereira para diâmetro médio $\mathrm{x}$ mediana

Figura 60: Parâmetros estatísticos médios de Folk \& Ward (1957) do leque aluvial Colônia Pereira para mediana $\mathrm{x}$ assimetria.

Figura 61: Parâmetros estatísticos médios de Folk \& Ward (1957) dos leques aluviais Cambará e Cachoeirinha para diâmetro médio $\mathbf{x}$ mediana

Figura 62: Parâmetros estatísticos médios de Folk \& Ward (1957) dos leques aluviais Cambará e Cachoeirinha para mediana $\mathrm{x}$ assimetria.

Figura 63: Parâmetros estatísticos médios de Folk \& Ward (1957) do leque aluvial Cubatão para diâmetro médio $\mathrm{x}$ mediana.

Figura 64: Parâmetros estatísticos médios de Folk \& Ward (1957) do leque aluvial Cubatão para mediana $\mathbf{x}$ assimetria.

Figura 65: Parâmetros estatísticos médios de Folk \& Ward (1957) dos leques aluviais para diâmetro médio $x$ mediana.

Figura 66: Parâmetros estatísticos médios de Folk \& Ward (1957) dos leques aluviais para mediana $x$ assimetria

Figura 67: Parâmetros estatísticos médios de Folk \& Ward (1957) dos le ques aluviais Brejatuba, Pombas, Caovi e Miranda para diâmetro médio $\mathrm{x}$ mediana

Figura 68: Parâmetros estatísticos médios de Folk \& Ward (1957) dos leques aluviais Brejatuba, Pombas, Caovi e Miranda para mediana $x$ assimetria.

Figura 69: Valores Médios de CM (Passega, 1957) por Unidade Estratigráfica.

Figura 70: Diagrama CM (Passega, 1957) para sedimentos da Formação Alexandra na região de Alexandra .88

Figura 71: Diagrama CM (Passega, 1957) para sedimentos da Formação Alexandra na região de Guaraqueçaba.

Figura 72: Diagrama CM (Passega, 1957) para todas as amostras da Formação Alexandra 
Figura 73: Diagrama CM (Passega, 1957) para sedimentos do leque aluvial Colônia Pereira.

Figura 74: Diagrama CM (Passega, 1957) para sedimentos do leque aluvial Cambará

Figura 75: Diagrama CM (Passega, 1957) para sedimentos do leque aluvial Cachoeirinha.

Figura 76: Diagrama CM (Passega, 1957) para sedimentos do leque aluvial Morretes

Figura 77: Diagrama CM (Passega, 1957) para sedimentos do leque aluvial Cubatão.

Figura 78: Diagrama CM (Passega, 1957) para sedimentos de todos os leques luviais

Figura 79: Diagrama CM (Passega, 1957) para sedimentos dos leques aluviais Brejatuba, Pombas, Caovi e Miranda.

Figura 80: Porcentagens médias de ocorrência dos minerais pesados opacos e transparentes por unidades estratigráficas.

Figura 81: Porcentagens médias dos tipos de minerais pesados transparentes por unidades estratigráficas.

Figura 82: Frequiências médias de ocorrência dos minerais pesados transparentes por unidades estratigráficas.

Figura 83: Gráfico de ATD mostrando o comportamento da argila do leque aluvial Morretes. .99

Figura 84: Gráfico de ATD mostrando o comportamento da argila do leque aluvial Cambará. 99 


\section{LISTA DE TABELAS}

Tabela 1: Classificação dos sedimentos em campo. 


\section{RESUMO}

O trabalho teve como objetivo o estudo sedimentológico e estratigráfico da Formação Alexandra e de outros sedimentos continentais cenozóicos que ocorrem na região litorânea do Estado do Paraná. Além de uma caracterização geral, com abordagem dos aspectos geomórficos, o trabalho conta com apresentação dos resultados de estudos sedimentológicos e discussão dos possíveis modelos deposicionais desses depósitos.

Os afloramentos de sedimentos da Formação Alexandra ocorrem em duas regiões: uma nas proximidades da estrada Alexandra - Matinhos e outra nas proximidades do rio Guaraqueçaba. As características sedimentológicas dos depósitos são diferentes para cada região, com predomínio de areia e lama na primeira região e predomínio de cascalhos sustentados por clastos na outra. O modelo deposicional admitido para esta formação é de fácies distal de leque aluvial, dividindo-se em fácies de fluxos de lama, de rios entrelaçados com canais confinados e de rios entrelaçados com canais não-confinados.

Também foram mapeados sedimentos continentais, associados às vertentes da Serra do Mar, que apresentaram características sedimentológicas e geomórficas características de leques aluviais, presumivelmente quaternários. Foram descritos nove leques aluviais na planície costeira do Estado do Paraná, com predomínio de sedimentos arenosos. O modelo deposicional interpretado para estas unidades foi de fácies proximal e distal de leques aluviais, sendo esta dividida em fácies de fluxos de lama, de rios entrelaçados com canais não-confinados, de rios entrelaçados com canais confinados e lagos. 


\begin{abstract}
The present work purposes the sedimentologic and stratigraphic studies of Alexandra Formation and other cenozoic continental sediments. Besides general survey, this work includes the results of sedimentological studies and discussions about possible depositional models.

The occurence of Alexandra Formation sediments were mapped in two regions: near from PR 508 (Alexandra - Matinhos road) and in Guaraqueçaba region, near from PR 404 road. Sedimentological caracterization of these deposits are diferent to each region. Near from PR 508 was registered the predomination of sand and mud; and near from PR 404 it was registered the predomination of gravel clasts suported.

Continental sediments associated to slopes of Serra do Mar with sedimentological and geomorphological caracteristics of alluvial fans, probably from Quaternary, were also mapped.
\end{abstract}

Were described the presence of nine alluvial fans on the coastal plain of Paraná State, with predomination of sandy deposits. 


\section{INTRODUÇÃO}

Apesar de terem sido realizados numerosos trabalhos geológicos na região litorânea do Estado do Paraná, principalmente nas décadas de 50 e 60 (Bigarella et al., 1959; Ab’Sáber \& Bigarella, 1961; Bigarella, 1965), houve um decréscimo no número de publicaçðes para as duas últimas décadas. Os trabalhos geológicos mais recentes são de Cunha Neto (1984a; 1984b), Martin \& Suguio (1986), Tessler \& Suguio (1987), Martin et al. (1988) e Lima \& Angulo (1990) e Angulo (1992).

No que se refere aos sedimentos continentais cenozóicos, os trabalhos realizados na região são muito escassos. Apenas nesta década é que se realizaram estudos para melhor reconhecimento dos sedimentos continentais na região da planície costeira do estado do Paraná, tais como Lima \& Angulo (1990), Angulo (1992) e Angulo (1995). Também nestes estudos mais recentes é que houve a preocupação em realizar uma melhor interpretação sobre os ambientes deposicionais e o posicionamento estratigráfico destas unidades.

\section{OBJETIVOS}

O objetivo geral deste trabalho é a caracterização sedimentológica e estratigráfica, juntamente com uma interpretação paleoambiental da Formação Alexandra e dos leques e cones aluviais associados à Serra do Mar. Pretende-se que este trabalho seja uma contribuição à evolução dos estudos geológicos e paleogeográficos cenozóicos do litoral paranaense.

Para atingir os objetivo proposto foram estudados os tipos de fácies, as relações estratigráficas e de contato, os sistemas deposicionais e a cronologia das unidades sedimentares. 


\section{MATERIAIS E MÉTODOS}

Para a realização dos estudos sedimentológicos e estratigráficos dos depósitos encontrados, houve uma seqüência de etapas que envolveram diversos métodos e técnicas de trabalho e podem ser divididas da seguinte forma:

- pesquisa bibliográfica;

- fotointerpretação preliminar;

- trabalhos de campo;

- trabalhos de laboratório;

\subsection{PESQUISA BIBLIOGRÁFICA}

Foi realizada catalogação e pesquisa do material bibliográfico sobre trabalhos já efetuados no litoral paranaense, trabalhos realizados em áreas similares e trabalhos teóricos sobre sedimentos continentais. A leitura deste material foi feita em paralelo às outras etapas. Os temas analisados envolvidos com o escopo do trabalho são os seguintes:
a) Formação Alexandra - caracterização, idade e ambiente deposicional;
b) Comparação com outras unidades similares à Formação Alexandra;
c) Caracterização sedimentológica, faciológica e deposicional dos sedimen- tos de leques aluviais;
d) Caracterização de depósitos sedimentares relacionados a fluxos gravitacio-nais, na porção paranaense da Serra do Mar;
e) Aloestratigrafia e caracterização de modelos sedimentares aloestratigráfi- cos no Brasil;
f) Classificação de rochas sedimentares;
g) Evolução tectônica e fisiográfica da região sudeste do Brasil;
h) Análises laboratoriais (sedimentologia, mineralogia de minerais pesados, morfoscopia e análise termodiferencial - ATD);
i) Trabalhos sobre determinação da orientação de seixos. 
Sobre a Formação Alexandra, procurou-se abranger todas as informações relativas a essa unidade, desde os trabalhos pioneiros até os trabalhos mais recentes. Isto permitiu que se fizesse uma análise prévia sobre as atividades e interpretações já desenvolvidas para a referida formação.

Também analisando a bibliografia sobre outros depósitos sedimentares com modelos genéticos similares à Formação Alexandra, procurou-se entender qual foi o procedimento utilizado para o estudo desses depósitos e como se chegou à interpretação genética e aos seus modelos deposicionais.

Pesquisou-se a bibliografia sobre os leques aluviais, tendo em vista que este era o sistema deposicional dominante nas áreas estudadas, tanto da Formação Alexandra como de depósitos mais recentes.

Procurou-se estudar toda a documentação existente sobre depósitos sedimentares originados por fluxos gravitacionais na região paranaense da Serra do Mar. É necessário frisar que nos documentos sobre a geologia da região litorânea do Paraná, a Formação Alexandra é a única unidade relacionada à modelos de leques aluviais.

Pesquisou-se sobre aloestratigrafia, baseando-se nos códigos de classificação estratigráfica e em trabalhos realizados no Brasil. A pesquisa deste tema teve como objetivo a tentativa de classificação aloestratigráfica para as unidades sedimentares com idades quaternárias.

$\mathrm{Na}$ classificação das rochas sedimentares procurou-se a que melhor se adaptasse às características dos depósitos encontrados, tentando viabilizar uma interação entre as observações de campo e as interpretações dos paleoambientes.

Com relação à evolução tectônica e fisiográfica da região sudeste do Brasil, deve-se levar em conta que o tema está estreitamente relacionado à história geológica dos sedimentos estudados, assim como de unidades correlatas como, por exemplo, a Formação Pariqüera-Açu. 
As diversas análises laboratoriais foram tema de estudo para se entender e selecionar as formas de obtenção de dados que pudessem auxiliar nas interpretações das unidades envolvidas.

Os trabalhos para determinação de orientação de seixos foram feitos em função da característica de alguns depósitos encontrados que possibilitaram a obtenção de dados sobre as paleocorrentes.

\subsection{FOTOINTERPRETAÇÃO PRELIMINAR}

Esta etapa, além de servir como base para realização do mapa geológico, também auxiliou nos trabalhos de campo, através do conhecimento preliminar sobre a área. Foram utilizadas fotos nas escalas 1:70.000 de 1963 e 1:25.000 de 1980, as quais foram emprestadas do Setor de Meio Ambiente do Instituto Paranaense de Desenvolvimento Econômico e Social - IPARDES. Também foram emprestadas junto a este setor, as cartas topográficas nas escalas 1:50.000 e 1:100.000 do Ministério do Exército (DSG), que recobrem toda a região do litoral paranaense. Nesta cartas foram plotados os afloramentos descritos nos trabalhos de campo.

$\mathrm{Na}$ fotointerpretação foi traçada a rede de drenagem mais importante da região, passando em seguida à análise das feições geomórficas que mais interessavam à pesquisa dos sedimentos continentais da planície costeira paranaense.

\subsection{TRABALHOS DE CAMPO}

Esta etapa foi realizada com o apoio da fotointerpretação preliminar e teve os seguintes procedimentos: descrição dos afloramentos com identificação da litologia, texturas, estruturas sedimentares e suas atitudes, tipos de matriz, forma, arredondamento, tamanho e composição dos clastos e outras observações que se fizessem necessárias. Em afloramentos com melhor exposição, foram realizados perfis onde foram anotadas as espessuras das camadas, suas litologias e os tipos de estruturas com suas atitudes. 
A amostragem foi feita em todos os afloramentos descritos, tendo sido coletados em torno de dois quilos de sedimento por amostra. Nos sedimentos em que ocorriam raizes fósseis, troncos e folhas preservadas, foram coletados com bastante cuidado para que se pudessem realizar possíveis classificações e datações.

Form percorridos cerca de $6.500 \mathrm{Km}$ e descritos 74 afloramentos em toda a área estudada, a maior parte nas imediações da estrada Alexandra-Matinhos. Ao todo, foram coletadas 203 amostras que foram levadas aos laboratórios de sedimentologia do Departameno de Geologia e do Centro de Estudos do Mar (CEM), ambos da UFPR, para análise granulométrica.

Para a Formação Alexandra foram descritos e coletados sedimentos de 21 afloramentos, sendo que deste total 12 afloramentos são novos. Também foram descritos e amostrados sedimentos de 9 cones e leques aluviais.

Também foi realizada a medição de orientação de seixos em afloramentos que continham cascalhos com seixos imbricados. São quatro afloramentos que apresentam estas características, sendo que tres deles referem-se à Formação Alexandra: dois afloramentos na estrada entre a PR 405 e a localidade de Batuva e um afloramento na PR 405 próximo à estrada para Batuva. O outro afloramento faz parte do Leque Marumbi e se localiza próximo à cidade de Morretes no rio Marumbi. O aparelho utilizado para a medição (Fig. 1B) foi projetado pelo Prof. João José Bigarella (Becker, 1976), sendo que para cada afloramento procurou-se realizar no mínimo 30 medições. A vantagem da utilização deste aparelho está na praticidade de fazer as medições em campo, evitando coletar os seixos para fazer as medições em laboratório.

O processo da medição com este aparelho, descrito por Becker (1976), consiste no seguinte: coloca-se o tripé com o aparelho junto ao afloramento e na altura que se queira efetuar as medições. Desloca-se o tubo interno até que as hastes (Fig. 1A) consigam atingir o seixo em três pontos não colineares, que deverão ser marcados com um lápis. Em seguida retrai-se o tubo sem movimentar o resto do conjunto. $O$ 
seixo é retirado do afloramento e imediatamente adaptado aos ponteiros, como quando encontrava-se no depósito.

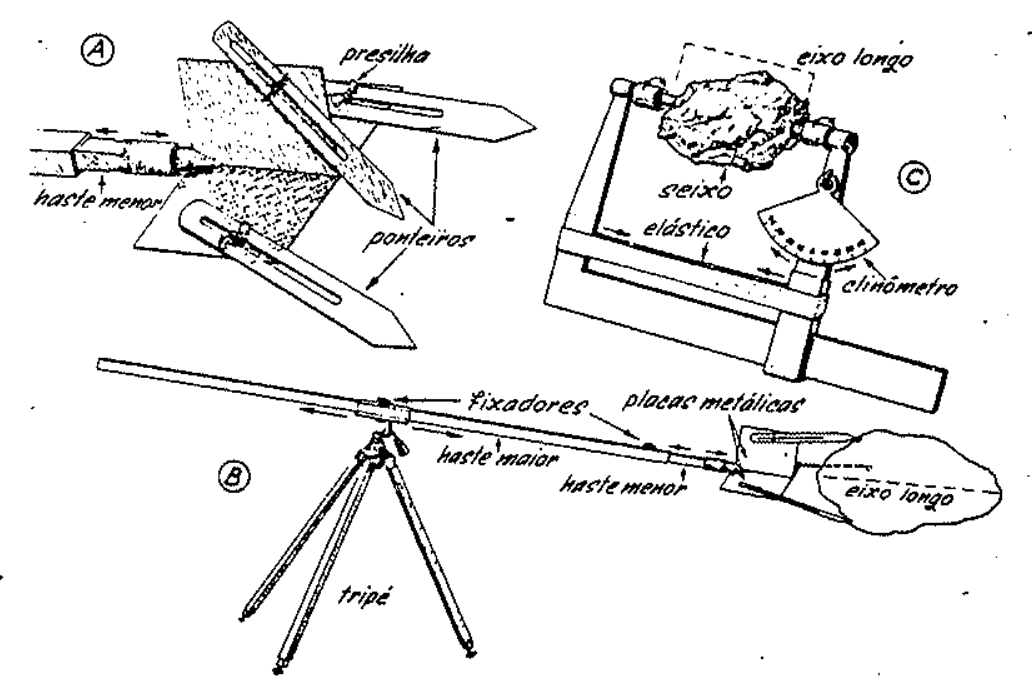

Figura 1: Detalhe do aparelho utilizado para medição de seixos (Becker, 1976).

Nesta posição adapta-se o clinômetro ao eixo longo do seixo (Fig. 1C), medindo-se o ângulo de inclinação e com uma bússola mede-se o sentido da inclinação. Também foi realizada a medição de comprimento dos três eixos e identificada a litologia.

A representação dos dados de orientação dos seixos seguiu os procedimentos de Suguio (1973), optando-se pelo diagrama em roseta. Os vetores resultantes do sentido de inclinação e do fator de consistência (F.C.) foram calculados a partir das seguintes fórmulas (Collinson \& Thompson, 1989), respectivamente:

$$
\operatorname{tg} \theta=\frac{\sum \operatorname{sen} \theta}{\sum \cos \theta} \quad \text { F.C. }=\frac{\sqrt{\left(\sum \operatorname{sen} \theta\right)^{2}+\left(\sum \cos \theta\right)^{2}}}{n}
$$

onde $\theta$ refere-se ao ângulo médio do sentido de inclinação, $\Sigma \operatorname{sen} \theta$ e $\Sigma \cos \theta$ somatórias de senos e cossenos de cada medida e $n$ o número de medidas realizadas. 


\subsection{TRABALHOS DE LABORATÓRIO}

As análises que foram realizadas em laboratório são as seguintes: análises granulométricas, datação com $\mathrm{C}^{14}$, análise termodiferencial (ATD) e análises palinológicas:

Depois do acondicionamento e transporte das amostras aos laboratórios de sedimentologia do Departamento de Geologia e do Centro de Estudos do Mar, ambos da Universidade Federal do Paraná, passou-se aos procedimentos das análises granulométricas que se basearam no método convencional de peneiramento e pipetagem, segundo Suguio (1973).

O material retido nas peneiras 0,125 e $0,062 \mathrm{~mm}$, passou pelo processo de separação das frações de "leves" e "pesados", através do bromofórmio. Na fração de "pesados" foi realizada a identificação mineralógica por petrografia microscópica. Para a montagem das lâminas que serviram à identificação de minerais pesados foram utilizados procedimentos usuais do laboratório de sedimentologia da UFPR, que referem-se à escolha das frações das peneiras menores que $0,250 \mathrm{~mm}$ e que estivessem abaixo da moda (Armando Marcio Coimbra - USP, comunicação pessoal apud Giannini, 1993). Este procedimento procurou selecionar a fração da amostra com maior concentração de minerais pesados, sendo que a maioria das lâminas (80\%) foi montada com partículas do intervalo $0,125-0,062 \mathrm{~mm}$. Os minerais pesados transparentes foram identificados através de observações das lâminas sob microscópio petrográfico de luz transmitida. Para a média de todos os grãos contados foi feita a discriminação em grupos de minerais transparentes e minerais opacos, sendo que estes não puderam ser identificados. Quanto aos minerais transparentes, foram divididos conforme a classificação de Pettijohn (1975): ultra estáveis (ZTR - zircão, turmalina e rutilo), estáveis (estaurolita, apatita e monazita), moderadamente estáveis (granada, cianita, sillimanita e pistachita) e instáveis (hornblenda, hiperstênio e andaluzita). 
Junto a esta etapa, foi feita a separação de amostras que foram encaminhadas para outros exames, como análise termodiferencial (ATD) e análise palinológica. O método de ATD teve como objetivo a identificação dos tipos de argila dos depósitos pesquisados e foi realizado no laboratório da Minerais do Paraná S.A. (MINEROPAR). Para esse método foram selecionadas 22 amostras de argila, sendo 8 amostras da Formação Alexandra e 14 amostras de leques aluviais quaternários, através do método de adsorção do azul de metileno, para determinação da capacidade de troca de cátions (CTC) dos argilominerais. Segundo Chen et al.(1974), o cátion azul de metileno substitui os cátions $\mathrm{Na}^{2+}, \mathrm{K}^{+}, \mathrm{Ca}^{2+}, \mathrm{Mg}^{2+}$ e $\mathrm{H}_{3} \mathrm{O}^{+}$adsorvidos aos argilominerais. Para este processo foi feito o peneiramento das amostras na peneira $0,062 \mathrm{~mm}$. Com o material que passou na peneira foi realizada uma solução com água para depois acrescentar azul de metileno em diversas etapas. Em cada etapa colocou-se uma gota da solução do azul de metileno em um papel de filtro. Se nesta gota apareceu apenas uma mancha escura o resultado foi considerado negativo e continuouse a adicionar azul de metileno, colocando novas gotas da solução no papel de filtro; até que aparecesse uma auréola clara em volta da mancha escura. Desta forma, o resultado foi considerado positivo e o teste encerrado. Em seguida, mediu-se o volume de azul de metileno utilizado para que pudesse ser incluído na seguinte fórmula:

$$
\mathrm{CTC}=\frac{\mathrm{V} \times \mathrm{C} \times 100}{\mathrm{M}} \text { onde, }
$$

$\mathrm{V}=$ volume da solução de azul de metileno gasta $(\mathrm{ml})$;

$\mathrm{C}=$ concentração da solução de azul de metileno (normalidade);

$\mathrm{M}=$ massa do solo seco $(\mathrm{g})$.

As amostras com resultados de CTC mais representativos foram selecionadas para realização do método de análise termodiferencial (ATD).

Foram enviadas 9 amostras de depósitos de leques aluviais presumivelmente quaternários ao Prof. Dr. Jean-Pierre Ybert, do Departamento de Botânica da UFRJ. 
Os resultados serviram como subsídio para interpretações paleoambientais, principalmente paleoclimáticas.

Duas amostras contendo restos vegetais, coletadas próximo aos rios Colônia Pereira e Cambará, foram encaminhadas ao Laboratório do Centro de Energia Nuclear na Agricultura (CENA) da USP em Piracicaba-SP, para datação pelo método do ${ }^{14} \mathrm{C}$.

O resultado de todas as análises mencionadas subsidiou a caracterização sedimentológica das unidades que foram pesquisadas, assim como a interpretação dos paleoambientes e gênese dos depósitos.

\section{CARACTERIZAÇÃo GERAL}

\subsection{LOCALIZAÇÃO E ACESSO}

A área pesquisada situa-se na região litorânea do Estado do Paraná, entre os meridianos $48^{\circ} 00^{\prime}-49^{\circ} 00^{\prime} \mathrm{W}$ e os paralelos $24^{\circ} 06^{\prime}-26^{\circ} 00^{\prime} \mathrm{S}$. Os municípios que dela fazem parte são: Paranaguá, Guaratuba, Matinhos, Antonina, Morretes e Guaraqueçaba, totalizando área de aproximadamente $5.600 \mathrm{Km}^{2}$ (Fig. 2).

As campanhas foram feitas, tanto em estradas pavimentadas como vicinais, utilizando-se veículos como caminhonete Toyota ou Volkswagen, cedidos pela MINEROPAR - Minerais do Paraná S.A.. Em alguns locais, principalmente nas partes de declives mais acentuados da Serra do Mar, não foi possível a continuação da campanha por automóvel, tendo sido feito o restante do percurso à pé, em trilhas de palmiteiros ou exploradores lenha.

As estradas pavimentadas que tornaram possível a locomoção por automóvel foram: a BR 277 que liga Curitiba-Paranaguá; a PR 408 que liga a BR 277 a Morretes e Antonina; a PR 411 que liga Morretes a Bairro Alto; a PR 410 que liga a PR 408 a BR 116, a PR 340 que liga a PR 408 à Usina Parigot de Souza, a PR 405 que liga a PR 340 à cidade de Guaraqueçaba, a PR 508 que liga a BR 277 à cidade de Matinhos e a PR 407 que liga a BR 277 ao Balneário de Praia de Leste. 


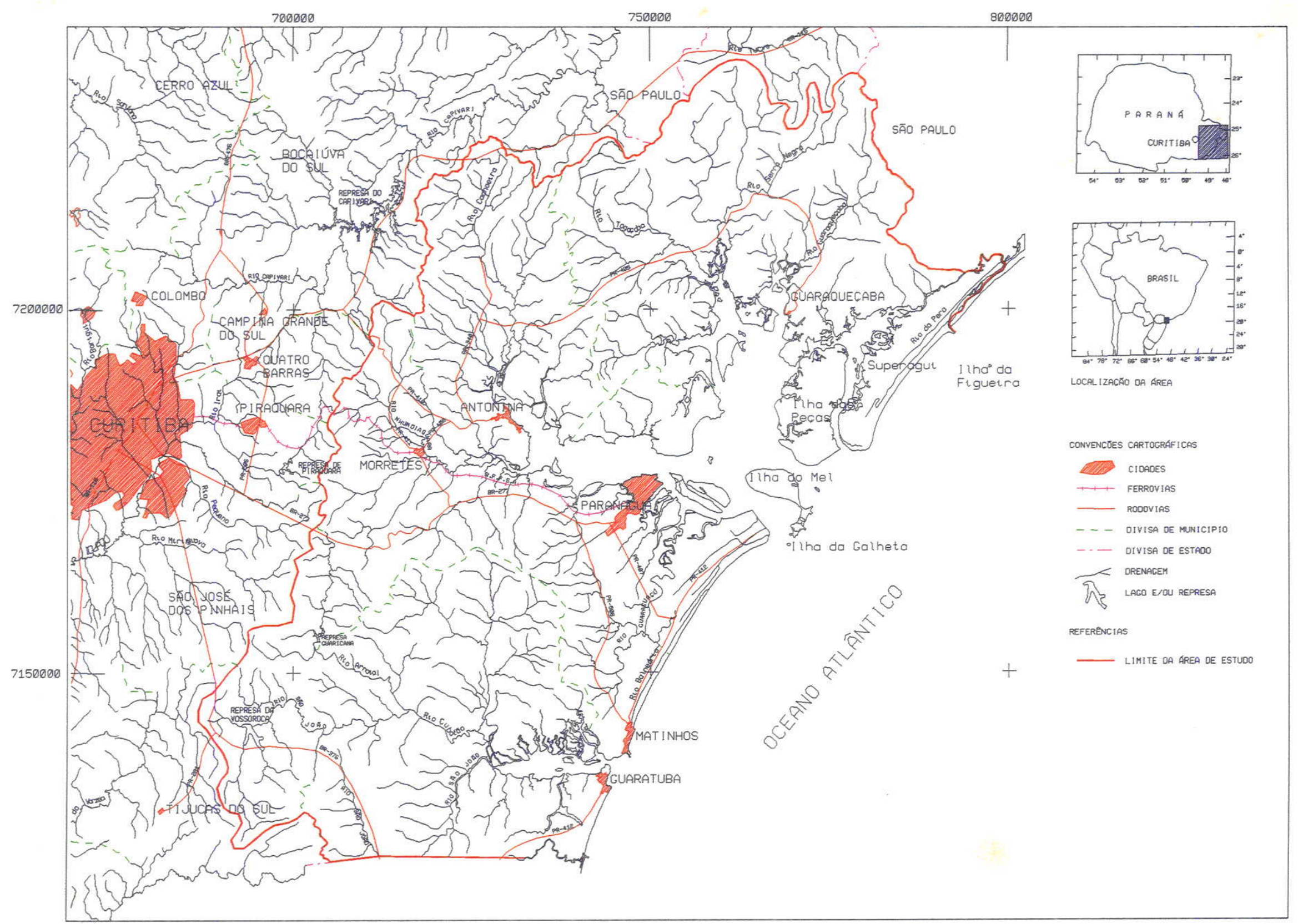

FIGURA 2 : MAPA DE LOCALIZAÇĀO E ACESSO A ÁREA PESOUISADA (MODIF. DE ANGULO, 1992) 
Entre as estradas vicinais percorridas destacam-se a que liga a cidade de Garuva (em Santa Catarina) e o rio Cubatão, a da Colônia Pereira que segue pelo rio do mesmo nome, a que segue os rios Cambará e Cachoeirinha, a que leva à localidade de América de Cima (nas proximidades de Morretes) e a que vai até a localidade de Batuva (próximo à cidade de Guaraqueçaba). Estas estradas são citadas devido aos bons afloramentos encontrados nos seus percursos.

\subsection{ASPECTOS GEOMÓRFICOS}

Segundo IPARDES (1989), a área em que se concentraram os estudos sedimentológicos está compreendida na Sub-região Planície Litorânea e na interface desta com a Sub-região Montanhosa Litorânea. Nesta ocorrem as seguintes Unidades Ambientais Naturais (U.A.N.'s): Serras, Áreas Coluviais e Planícies Aluviais. Na Subregião das Planícies Litorâneas encontram-se as U.A.N.'s de Planícies Aluviais, Planícies de Restingas, Morros, Áreas Coluviais, Colinas e Mangues.

Os afloramentos da Formação Alexandra que foram descritos ocorrem na Sub-região Planície Litorânea, mais especificamente em Unidades Ambientais Naturais - UANs - do tipo colinas, que se caracterizam pela baixa altitude e declividade bem menos acentuada que as da serra. As colinas diferenciam-se dos morros por estes serem mais altos e mais ígremes, com declividades superiores a $45 \%$ e geralmente sustentados por rochas do embasamento (IPARDES, 1989).

Os sedimentos continentais mais modernos que os da Formação Alexandra, como os leques e cones aluviais, foram encontrados nas áreas adjacentes à Sub-região Montanhosa Litorânea e em transição com a Sub-região Planície Litorânea. Encontram-se nas partes baixas das vertentes, onde ocorreram processos de acumulação de sedimentos provenientes das partes altas da Serra do Mar. 


\subsection{GEOLOGIA GERAL}

A área pesquisada situa-se na Região do Litoral Paranaense (IPARDES, 1989), que no contexto geológico divide-se em dois grupos principais: rochas do Embasamento Cristalino e sedimentos de idade cenozóica.

As rochas do Embasamento estão relacionadas às unidades geomórficas da Serra do Mar e de morros isolados na planície litorânea. Segundo o trabalho realizado pela MINEROPAR (1989), estas unidades subdividem-se em nove grupos litoestratigráficos principais:

a) Complexo Granulítico Serra Negra - mais antigo (acima de 2.500 m.a.), composto por quartzitos, xistos, gnaisses, metabasitos, metarenitos, metarcósios e granulitos gnáissicos;

b) Complexo Máfico-ultramáfico de Pien - rochas calcossilicáticas anfibolíticas;

c) Complexo Gnáissico-migmatítico Costeiro - com idade em torno de 2.200 m.a., estando representado por granitos (Granito Cachoeira), granitosgnaisses, anatexitos, migmatitos, embrechitos e quartzitos;

d) Suíte Gnáissica Morro Alto - biotita gnaisses com intercalação de micaxistos e quartzitos;

e) Formação Rio das Cobras - xistos, quartzitos e metaultrabásicas;

f) Suíte Granítica Foliada - granitos e granitóides embrechíticos;

g) Suíte Granítica-cornubianítica brasiliana:

g.1) Granito a Sienito-granito Alto Turvo - idade em torno de 630 m.a.;

g.2) Granitos subalcalinos a alcalinos - conjunto composto pelos granitos Graciosa (513 m.a.), Marumby (495 m.a.), Morro Redondo (506 m.a.) e Serra da Igreja;

h) Formação Guaratubinha - riolitos e piroclastitos ácidos com andesitos e dacitos que possuem idade entre 530 e 550 m.a.; 
i) Intrusivas Básicas, representadas por diques básicos que compreendem dioritos e traqui-andesitos, com idades entre 113 e 136 m.a..

A origem da Serra do Mar está relacionada ao Rifte Continental do Sudeste do Brasil (Riccomini, 1989), com feição alongada e deprimida, desenvolvida entre as cidades de Curitiba (PR) e Niterói (RJ), numa extensão de aproximadamente $800 \mathrm{Km}$. A origem da depressão inicial encontra-se no Paleógeno e estaria relacionada ao campo de esforços extensionais NNW-SSE, imposto pelo basculamento termomecânico na Bacia de Santos. A reativação de antigas zonas de cisalhamento brasilianas proporcionou a formação de hemi-grábens que receberam espessuras consideráveis de sedimentos, tais como os depósitos da Formação Pariqüera-Açu no litoral paulista e Formação Alexandra no litoral paranaense (Riccomini, op. cit.).

Quanto aos sedimentos da planície litorânea do Paraná, Martin et al. (1988) apresentam, em Mapa Geológico do Quaternário Costeiro do Estado do Paraná e Santa Catarina, dados geológico-estratigráficos para esta região, dividindo os depósitos sedimentares da seguinte forma:

Holoceno - sedimentos argilo-arenosos, ricos em matéria orgânica dos mangues atuais; - sedimentos argilosos e arenosos de lagunas e baías podendo conter conchas de moluscos e/ou ser cobertos por uma camada de turfa;

- sedimentos argilo-arenosos flúvio-lagunares;

- sedimentos continentais indiferenciados, mal selecionados: coluviões de pé-de-relevo e aluviões fluviais.

Pleistoceno - areias marinhas litorâneas bem selecionadas, podendo apresentar cor escura devida à presença de matéria orgânica de origem secundária.

Quaternário Indiferenciado - sedimentos continentais indiferenciados, mal selecionados:

coluviões de pé-de-relevo e aluviões fluviais.

Plioceno - sedimentos continentais mal selecionados do tipo bajada depositados em condições de clima semi-árido. 


\section{TRABALHOS PRÉVIOS}

\subsection{FORMAÇÃO ALEXANDRA}

Esta formação foi proposta por Bigarella et al. (1959) e descrita como uma seqüência de depósitos sedimentares encontrados próximos à localidade homônima, junto à estrada Curitiba-Paranaguá. Os autores atribuiram uma origem possivelmente tectônica para a Formação Alexandra, relacionada à fase final de formação da Serra do Mar (Terciário).

A espessura máxima observada em afloramento é de aproximadamente 24 metros, predominando depósitos rudáceos na base e apresentando lentes e camadas de arcósios e argilas na parte superior (Bigarella et al, op. cit.). Os autores também correlacionaram os depósitos da Formação Alexandra aos sedimentos da Formação Guabirotuba (Bacia de Curitiba), baseados na similaridade litológica.

Fuck et al. (1969), esboçaram um mapeamento preliminar do litoral e também correlacionaram os argilitos e arcósios da Formação Alexandra com os sedimentos da Formação Guabirotuba.

Dividindo a planície sedimentar do estado do Paraná, Bigarella (1978) novamente refere-se às características litológicas da Formação Alexandra.

Martin et al. (1988), incluem a Formação Alexandra em seus trabalhos sobre a planície litorânea entre o Paraná e Santa Catarina. Relacionam esta formação ao Plioceno e descrevem-na como sedimentos mal selecionados do tipo bajada, depositados em condições de clima semi-árido.

Apeasar de vários ambientes de sedimentação já terem sido referidos à Formação Alexandra, como flúvio-lacustre (Bigarella et al., 1961), bajada e playa- 
lake em clima semi-árido (Ab'Sáber \& Bigarella, 1961) e fluvial (Silva et al., 1981), o ambiente de leque aluvial foi proposto pela maioria dos autores que a estudou e, portanto, indicado como ambiente de sedimentação mais característico desta formação.

Silva et al. (1981) incluiram os sedimentos encontrados próximo à cidade de Guaraqueçaba na Formação Alexandra pela similaridade litológica com os depósitos característicos desta formação.

Lima \& Angulo (1990) encontraram camada de argila carbonosa com bastante matéria vegetal na parte média do afloramento localizado no encontro da $\mathrm{BR}$ 277 (Curitiba - Paranaguá) com a PR 508 (Alexandra - Matinhos). O resultado das análises palinológicas mostrou a presença de algas, fungos, esporos e pólen, destacando-se como valor estratigráfico: Pseudoschizea circula, Cyatheacidites annulatus, Crassoretitriletes vanraadshooveni, Verrucatosporites usmensis, Monoporites annulatus, Areolipolis vespiformes (= Multiareolites formosus) $e$ Retitricolporites hispidus. O conjunto dessas espécies permitiu atribuir à Formação Alexandra uma idade correspondente à parte alta do Mioceno inferior.

Com relação ao paleoclima, Lima \& Angulo (op. cit.) atribuem a presença da camada de argila carbonosa a um clima com capacidade de manter um corpo permanente de água, mesmo que restrito. A vegetação local estaria bem adaptada a essas condições (abundância de algas, fungos, pteridófitas e angiospermas aquáticas). Entretanto, a vegetação regional sugere predominância de elementos herbáceos ou arbustivos (labiadas, gramíneas e compostas) sobre os elementos arbóreos, que esse seria sugestiva de clima mais seco.

Segundo Melo (1990), os depósitos da Formação Pariqüera-Açu seriam correlacionáveis aos da Formação Alexandra, não só pela similaridade litológica, mas também pelo comportamento topográfico de ambos depósitos e pela situação possivelmente contemporânea dessas unidades com nível marinho mais baixo que o atual. 


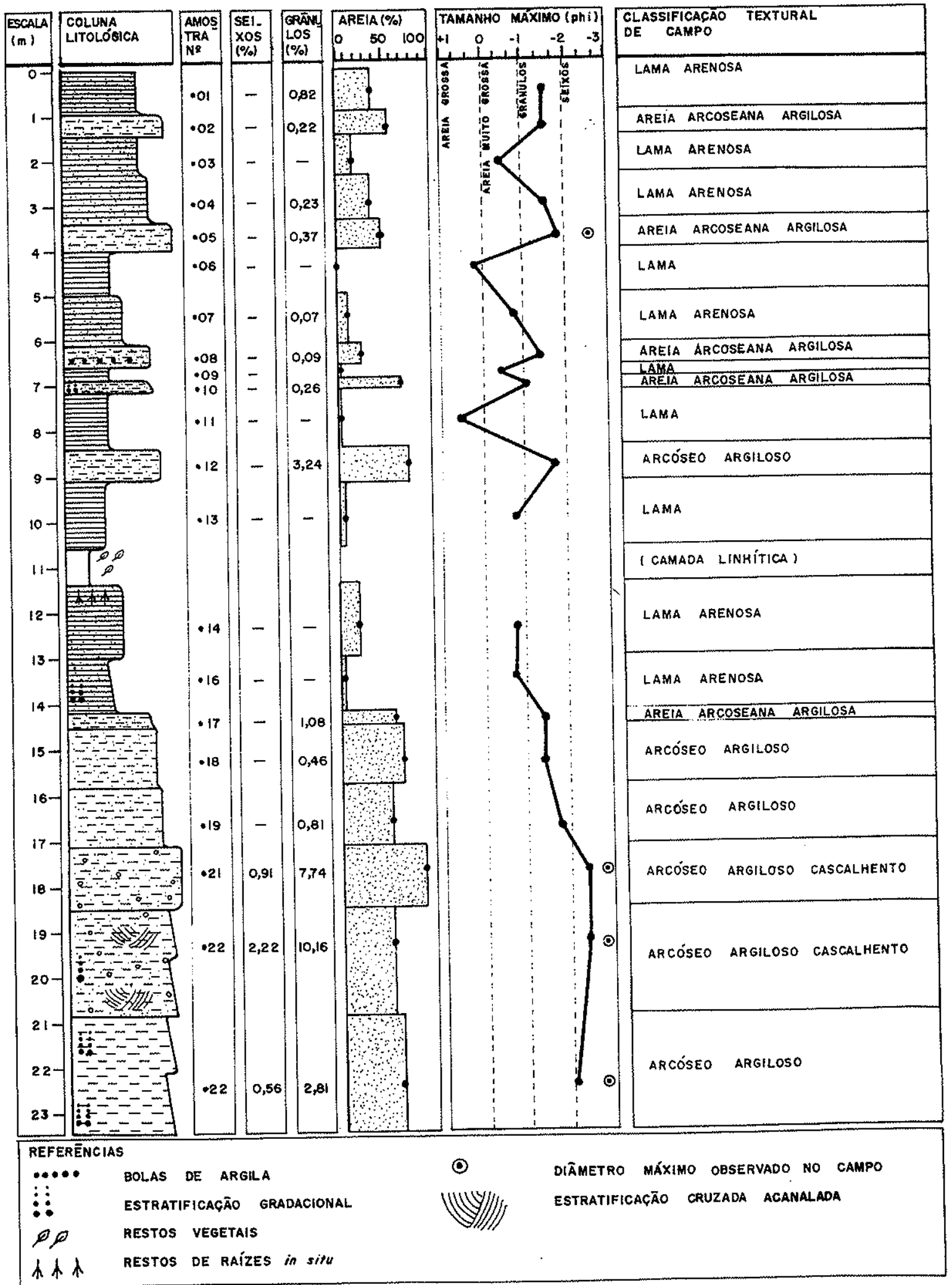

Figura 3: Seção-tipo da Formação Alexandra (Angulo, 1995). 
Angulo (1995) cria uma seção-tipo para a Formação Alexandra que se situa no cruzamento da BR 277 com a PR 508 (Fig. 3). O autor exclui desta formação parte dos depósitos que foram encontrados próximos à cidade de Guaraqueçaba por Silva $e t$ al. (1981), referindo-se à falta de evidências para incluí-los nesta formação. Para o autor estes depósitos teriam se originado de terraços fluviais mais recentes e mais baixos que os encontrados na Formação Alexandra.

Usando a classificação de Folk (1954), Angulo (1995) descreve os sedimentos encontrados, com predomínio de lama arenosa pouco cascalhenta (25\%) e areia lamosa pouco cascalhenta (22\%), seguidas de areia lamosa cascalhenta (14\%) e argila arenosa $(14 \%)$. Os feldspatos encontravam-se muito alterados, aumentando com isso os teores de silte e argila. Desta foi feita difração de raios-X dando como resultado a presença de moscovita e caulinita.

Quanto ao ambiente deposicional, Angulo (1992 e 1995) divide os depósitos da Formação Alexandra em dois tipos de fluxos gravitacionais: fluxo de detritos, que é representado por conglomerados sustentados pela matriz e corrida de lama, composto por lamas e lamas arenosas. O clima durante a deposição da Formação Alexandra teria sido úmido, entretanto, mais seco que o atual e com maior abundância de arbustos e plantas herbáceas.

\subsection{LEQUES ALUVIAIS QUATERNÁRIOS}

Segundo Blissembach (1954), os leques aluviais possuem três segmentos geomórficos bem definidos: fácies proximal (fanhead), que é a área de convergência para o ápice do leque; fácies mediana do leque (midfan), que é a área entre a fácies proximal e as margens inferiores do leque e a fácies distal (base) que pode gradar para zonas de coalescência com outros leques. Para Reineck \& Singh (1980), o ângulo de inclinação dos leques raramente excede $10^{\circ}$, estando normalmente entre 3 e $6^{\circ}$, sendo que o raio varia de poucas centenas de metros para $100 \mathrm{~km}$ ou mais. Quanto às características sedimentológicas, Rust \& Koster (1984) descrevem que o tamanho dos grãos diminuem rapidamente do ápice para a base dos leques, mas em contrapartida, 
ocorre aumento no grau de arredondamento e na proporção de fácies de granulometria fina.

Os leques aluviais preservados que ocorrem na região do litoral paranaense, tiveram os mais diversos tipos de denominações em trabalhos anteriores, tais como os que seguem abaixo.

Bigarella (1946) refere-se à "depósitos de piemonte" como o material resultante da decomposição de rochas do embasamento e que foi transportado até a base das encostas da Serra do Mar, originando os "cones de detritos de piemonte".

Para Maack (1947), as formas que se apresentam em "amontoados de blocos e detritos" na Serra do Mar, foram originadas numa época de clima semi-árido do Quaternário antigo, através da desagregação mecânica das rochas das encostas.

$\mathrm{Na}$ divisa dos estados do Paraná e Santa Catarina, Bigarella et al. (1961) descobriram depósitos de seixos e matacões nas encostas das serras de Iquererim e São João e também no vale do rio São João, na estrada Curitiba-Joinville. Estes depósitos foram denominados pelos autores de Formação Iquererim e referem-se a eles como pedimentos detríticos muito grosseiros que se formaram em duas fases de pedimentação com clima semi-árido relacionadas ao Pleistoceno.

Bigarella (1965) refere-se à "depósitos terrígenos", de natureza coluvial que se fazem presentes na interface da Serra do Mar com a planície litorânea. O material encontrado possui uma textura síltico-argilosa, pouco arenosa.

Estudando a geologia da região de Morretes, Cordani \& Girardi (1967) verificaram a presença de pedimentos remanescentes encontrados nas fraldas das serras Graciosa e Marumbi, que mergulham sobre os sedimentos aluviais da planície litorânea. Estes depósitos são compostos de material rudáceo, sem seleção ou estrutura e foram correlacionados aos depósitos da Formação Iquererim. Entretanto, essa correlação carece defundamentos, pois os próprios autores verificaram a falta das fases de pedimentação atribuídas aos depósitos de Garuva (Bigarella et al.,1961), justificando que devido à retrabalhamentos as superfícies originais não teriam sido preservadas. 
Nos estudos da Comissão da Carta Geológica do Paraná, Fuck et al. (1969) separaram os depósitos da vertente da Serra do Mar em depósitos de talus, cones de dejeção e coluviões. Provavelmente, os leques e cones aluviais foram à época englobados no que os autores denominaram de cones de dejeção, os quais seriam formados, segundo os autores, por "torrentes e apresentam-se como uma mistura de blocos, seixos, areias e argila".

A Minerais do Paraná S.A. - MINEROPAR, realizou pesquisas prospectivas de ouro em duas áreas próximas à cidade de Morretes (Cunha Neto, 1984a,b). A pesquisa na área I concentrou-se em depósitos detríticos de material grosso, extremamente mal selecionado, procedente de amplos leques aluviais que foram originados pela coalescência dos depósitos desenvolvidos das escarpas de falha. Para a área II que está inserida no Complexo Migmatítico da Serra do Mar, foram estudados os depósitos de tálus e de cones aluviais, que são constituídos por material fanglomerático de idade quaternária.

Bigarella (1978) refere-se aos movimentos de massa ocorridos em episódios semi-áridos do Pleistoceno, principalmente durante as transições entre climas úmidos e semi-áridos, quando foram formadas grandes quantidades de depósitos de corridas de lama.

Martin \& Suguio (1986), estudando as planícies costeiras dos estados do Paraná e Santa Catarina, descreveram ocorrências de depósitos coluviais terrígenos de diferentes origens e idades, que representariam episódios de movimentos de massa generalizados e teriam sido formados em condições de clima semi-árido.

Em mapeamento geológico realizado por Martin et al. (1988), para as planícies costeiras do Paraná e Santa Catarina, os depósitos de leques e cones aluviais foram incluídos em grupo de "sedimentos continentais indeferenciados, mal selecionados: coluviões de pé de relevo e aluviões fluviais". Tentando posicionar cronológicamente estes depósitos, os autores os relacionam ao Quaternário Indiferenciado. 
Angulo (1995) considera como leques e cones aluviais as várias unidades que estão associadas às vertentes da Serra do Mar e que são compostas, principalmente, por rochas graníticas e migmatíticas. $O$ autor observa que sedimentologicamente essas unidades assemelham-se aos depósitos da Formação Alexandra, com grande variabilidade granulométrica e falta de estruturas sedimentares hidrodinâmicas.

Baseando-se no aspecto geomórfico dos leques, Angulo (1995) dividiu-os em dois tipos principais: o que corresponde ao leque do rio Cubatão e o que representa todos os outros leques aluviais. As características principais do leque do rio Cubatão é a declividade baixa (menor que $1^{\circ}$ ) e a existência de numerosos meandros e canais abandonados que se distribuem por sua superficie. Nos outros leques a declividade média varia entre $2^{\circ} \mathrm{e} 20^{\circ}$.

Baseando-se no nível de preservação dos leques e relevo semelhante ao atual, Angulo (1995) sugere idades recentes para origem dessas unidades, mas os leques mais dissecados teriam provável idade plio-pleistocênica e os menos dissecados idades peistocênica à holocênica.

\section{RESULTADOS E DISCUSSÃO}

\subsection{CLASSIFICAÇÃO}

Para os sedimentos aqui estudados foi adotada uma terminologia que se baseou na que foi utilizada por Melo (1990) e por Angulo (1995) para classificação dos sedimentos em campo (tabela 1).

Para a caracterização granulométrica, utilizou-se a classificação de Shepard (1954), através do programa LABSE2. Detalhes da classificação dos sedimentos em campo são apresentados abaixo. 
FINOS: Este termo foi utilizado para sedimentos com composição predominante de silte e argila com até $15 \%$ de partículas maiores. Tal como descrito por Melo (1990), esses sedimentos refletem principalmente regime de suspensão com deposição êm corpos de água tranquila.

LAMAS: São sedimentos com mais de $50 \%$ de matriz (silte+argila) e mais de $15 \%$ de partículas maiores que ocorrem dispersas aleatoriamente na matriz. Estão relacionados a processos de fluxos densos, podendo ser depósitos mais distais de leques aluviais ou representar falta de suprimento de partículas maiores que viriam formar os cascalhos sustentados por matriz.

AREIAS: Este termo foi utilizado em depósitos com frações de areia predominantes nos sedimentos. As areias grossas possuem mais de $15 \%$ de areia média e grossa, menos de $50 \%$ de areia fina a muito fina e foram originados em regime de tração por correntes aquosas de alta energia.

O termo areia fina foi utilizado em sedimentos com mais de $50 \%$ de areia fina a muito fina, menos de $15 \%$ de areia média e grossa e representam depósitos que se formaram em regime de tração por correntes aquosas de baixa energia.

AREIAS ARCOZIANAS: Este termo serviu para designar sedimentos com mais de $15 \%$ e menos de $25 \%$ de feldspatos. Os feldspatos normalmente são angulosos e alterados. Texturalmente podem ser semelhantes às areias grossas ou lamas. Essa semelhança também está relacionada aos processos de formação, ou seja, podem ter-se originado em regime de tração em correntes de alta energia (semelhante à areia grossa), ou por processos de fluxos densos (semelhante às lamas). 
RUDÁCEOS: Estes depósitos foram divididos em cascalhos sustentados por clastos e cascalhos sustentados por matriz (Rust \& Koster, 1984). Os cascalhos sustentados por clastos possuem menos de $15 \%$ de matriz, têm clastos imbricados, arredondados e foram depositados por correntes aquosas de alta energia. Os cascalhos sustentados por matriz possuem mais de $15 \%$ de matriz (silte+argila), os clastos geralmente são angulosos e estão dispersos aleatoriamente na matriz; tendo sido depositados por fluxos densos.

Tabela 1: Classificação dos sedimentos em campo

\begin{tabular}{|l|l|l|}
\hline \multicolumn{2}{|l|}{ SEDIMENTOS } & CARACTERÍSTICAS \\
\hline Finos (argila e/ou silte) & Até 15\% de partículas grossas (areia, grânulos, \\
etc.)
\end{tabular}

A classificação aqui apresentada foi adotada, tanto para os depósitos da Formação Alexandra, como para os depósitos das unidades mais modernas (leques aluviais quaternários). 


\subsection{DESCRIÇÃO DOS SEDIMENTOS}

\subsubsection{Formação Alexandra}

Além das ocorrências já conhecidas através de Bigarella et al. (1959) Silva et al. (1981) e Angulo (1995), neste trabalho foram encontrados doze afloramentos da Formação Alexandra, até agora desconhecidos.

Angulo (op. cit.) havia excluído parte dos depósitos encontrados próximos ao rio Guaraqueçaba e que haviam sido incluídos à Formação Alexandra por Silva et al. (1981), alegando serem depósitos de terraços fluviais mais modernos que a referida formação. Entretanto, optou-se por reincluí-los na Formação Alexandra, pois neste trabalho foram encontradas sequências de areias arcozianas e lamas, muito representativas desta formação, em meio aos cascalhos sustentados por clastos naquela localidade. Também nesta região, especificamente às margens da estrada que leva à cidade de Guaraqueçaba, foram encontradas várias ocorrências de depósitos de lamas e areias arcozianas.

Angulo (1995) incluiu à Formação Alexandra depósitos encontrados cerca de $5 \mathrm{~km}$ à noroeste da vila de Alexandra. Entretanto, em trabalhos de campo verificou-se apenas a ocorrência de granitos alterados, não tendo sido encontrados depósitos sedimentares neste local e, desta forma, foram excluídos da referida formação.

Quanto aos outros depósitos incluídos nesta formação, tanto em superficie (Rivereau et al., 1969) como subsuperficie (Bigarella \& Becker, 1975 e Bigarella, 1978), concorda-se com Angulo (1995), que descreve as características dos depósitos de superfície como depósitos de planície costeira com cordões litorâneos, enquanto que para os depósitos encontrados em subsuperfície deveriam ser feitas estudos sedimentológicos e estratigráficos mais detalhados para que possam ser incluídos na Formação Alexandra.

Assim sendo, nas análises realizadas para a Formação Alexandra, foram consideradas duas regiões distintas do litoral paranaense: das proximidade com a vila de Alexandra (Fig. 5) e da região próxima à cidade de Guaraqueçaba (Fig. 6). 


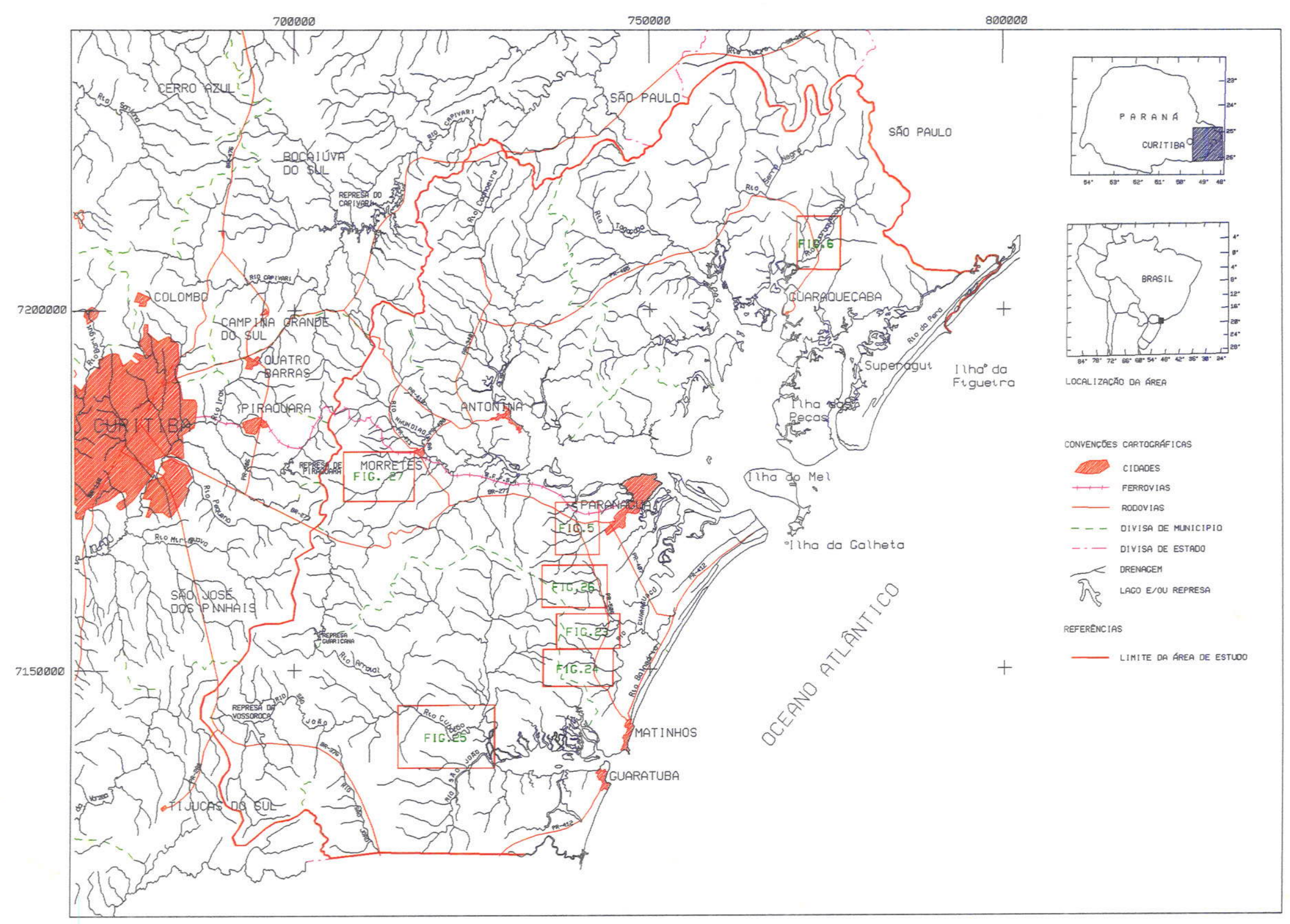

FIGURA 4 : MAPA DE ARTICULACÃO DOS MAPAS GEOLÓGICOS 


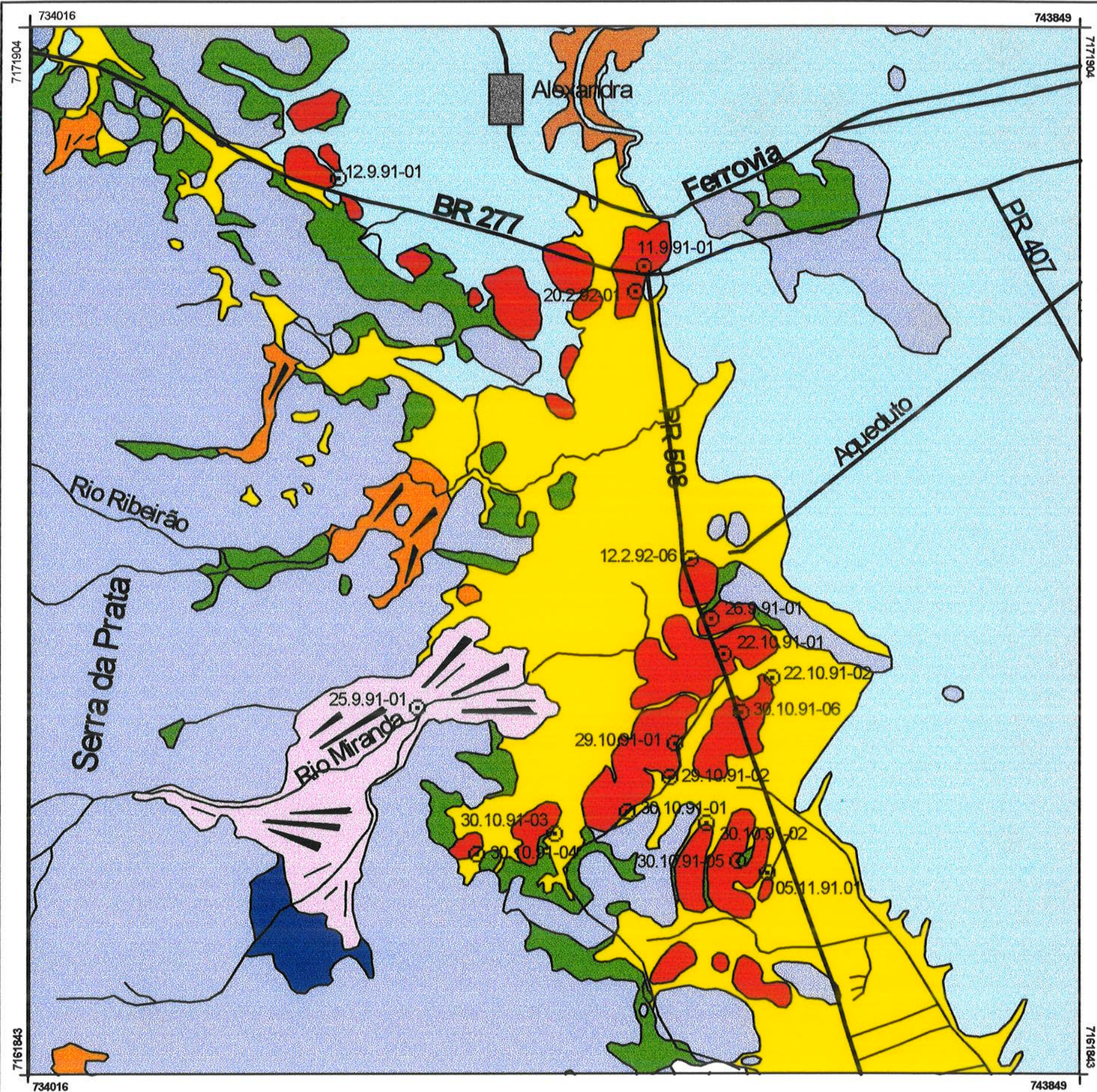

\section{LEGENDA}

\section{SEDIMENTOS}

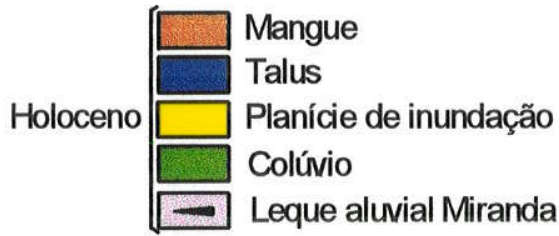

Quaternário Indiferenciado Leques e cones aluviais

Sedimentos de ambientes costeiros

Mioceno Inferior $\square$ Formação Alexandra

\section{OUTRAS REFERÊNCIAS}

(-) Pontos de descrição e coleta de sedimentos

$>$ Rios, córregos e canais

— Estradas

Embasamento cristalino pré-cenozóico
Escala Gráfica

$500 \quad 0 \quad 5001000$ Metros 


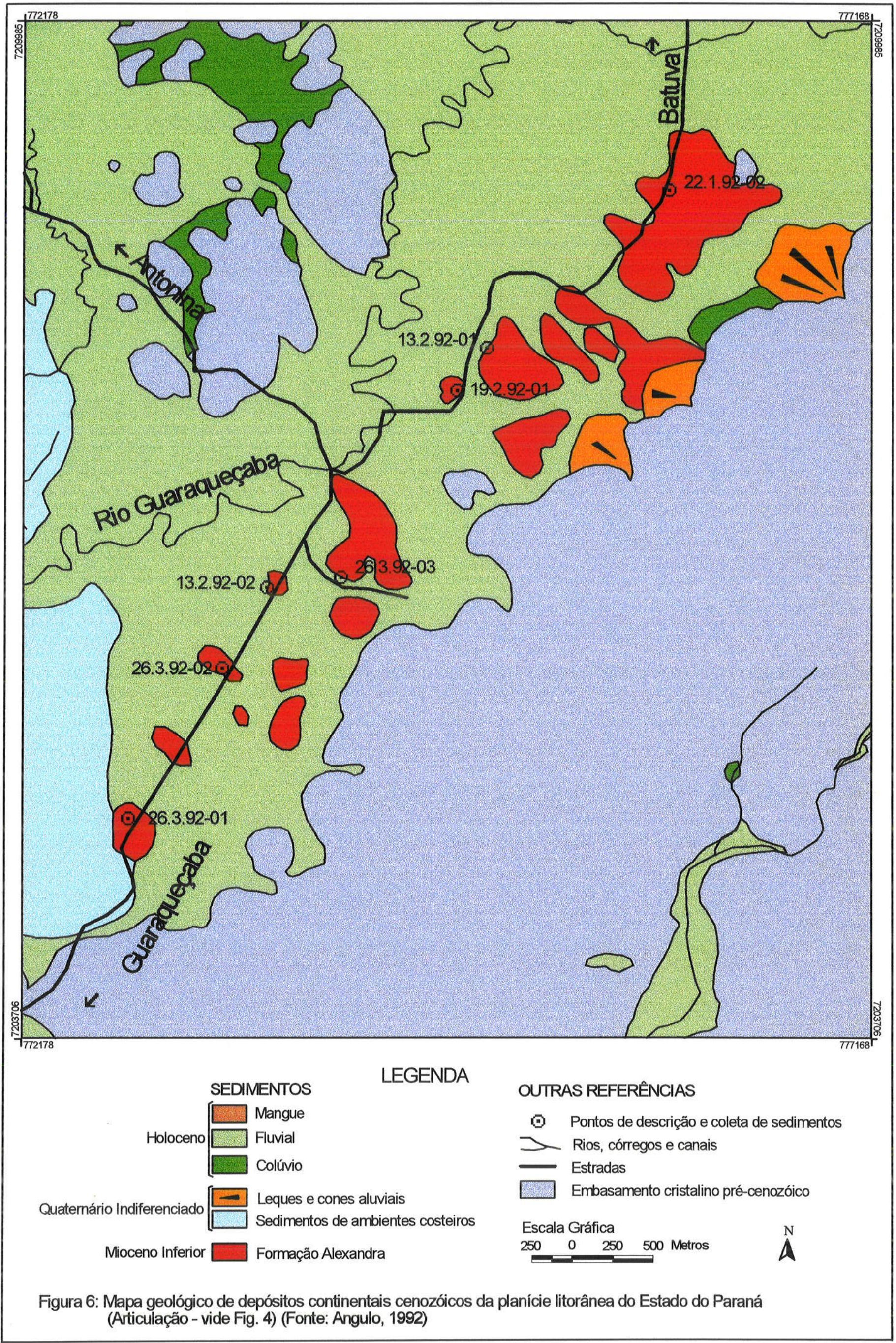




\subsubsection{Sedimentos}

Tal como descrito por Angulo (1992), os depósitos da Formação Alexandra ocorrem em colinas isoladas, com altitudes que não chegam a ultrapassar 30 metros. Essas elevações são muito similares as que são constituídas por rochas metamórficas do embasamento cristalino.

Reconhecidas as ocorrências de afloramentos da Formação Alexandra em duas regiões distintas, conforme o item anterior, verificou-se que nas proximidades da PR 508 (região de Alexandra), predominam lamas, ocorrendo subsidiariamente areia arcoziana e areia grossa. Raramente são encontrados finos e areia fina e apenas em um afloramento constatou-se a presença de cascalho sustentado por clastos. A cor cinza predomina nesses afloramentos e em menor proporção aparecem as cores violeta e amarela, sendo também comum as cores variegadas.

As lamas apresentam-se geralmente em camadas que variam de alguns centímetros até 1,50 metros. Normalmente ocorrem intercaladas com camadas mais arenosas (areia arcoziana ou areia grossa). No topo das camadas de lamas ocorrem canais escavados e preenchidos por areias, indicando processo erosivo pós-deposicional nestas camadas (Fig. 7). Internamente as lamas não apresentam estruturas, entretanto, no ponto 12.2.92-06 foram encontradas marcas de tubos (Fig. 8).

Grânulos de quartzo e feldspato bastante angulosos e algumas vezes subarredondados ocorrem dispersos aleatoriamente na argila. Os feldspatos geralmente estão bastante alterados. Em alguns afloramentos foi possível constatar a presença de muita mica branca, minerais pesados e muito raramente clastos de granito.

As areias arcozianas e areias grossas são muito semelhantes quanto ao aspecto textural, diferenciando apenas pela presença ou não de feldspatos. Os grãos de quartzo ocorrem angulosos a subarredondados e no caso das areias arcozianas, os feldspatos encontrados apresentam-se bastante alterados, já caulinizados, com granulometria de grânulos a seixos.

Micas e minerais pesados com proporções acima de $5 \%$ foram encontrados em alguns depósitos, sendo rara a ocorrência de clastos de granito. 


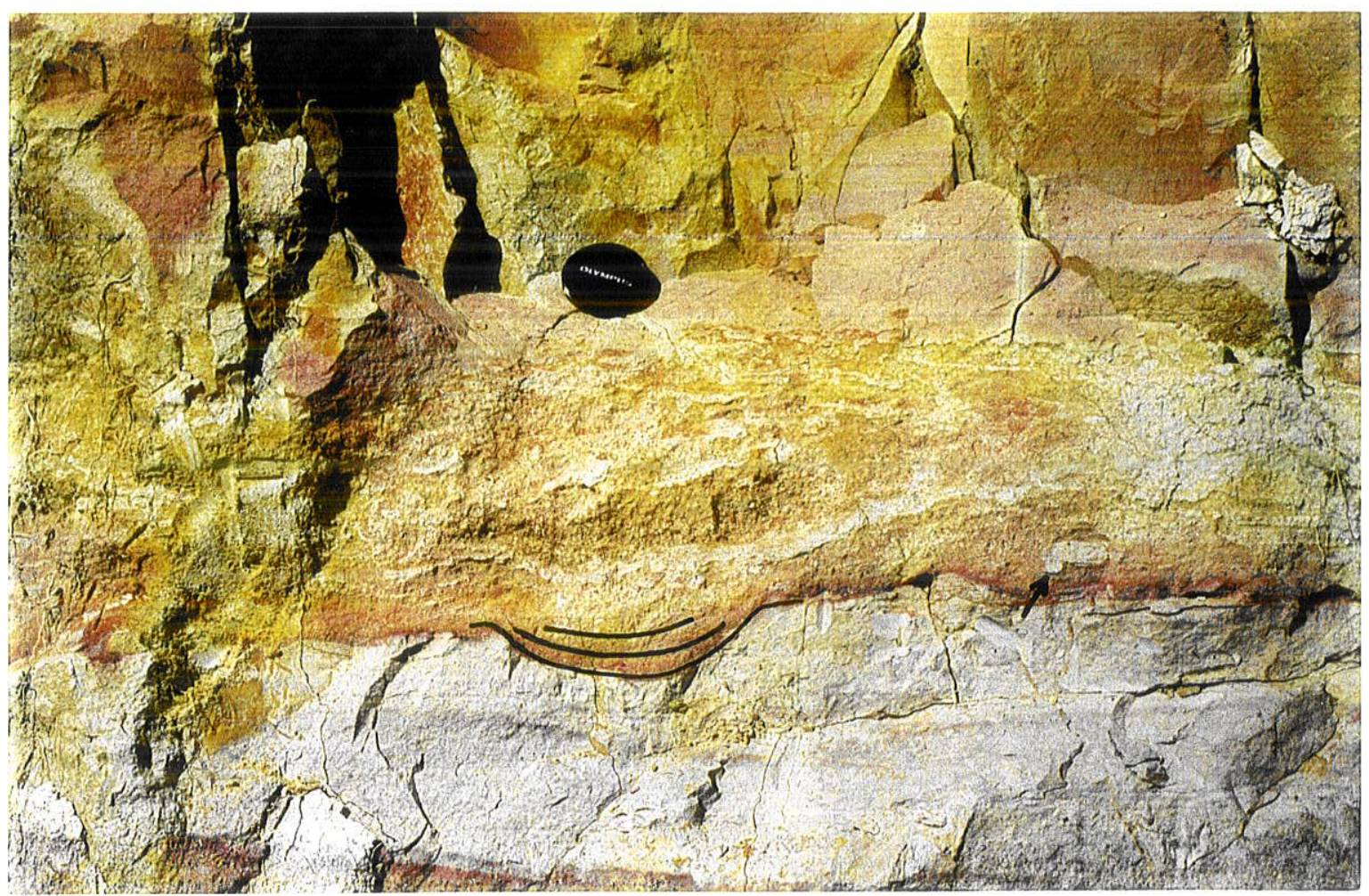

Figura 7: Areia arcoziana intercalada com camadas de lamas da Formação Alexandra. No topo da camada inferior de lama verifica-se a presença de canal e pelota de argila. Afloramento situado em frente à seção-tipo (ponto 20.2.92-01)

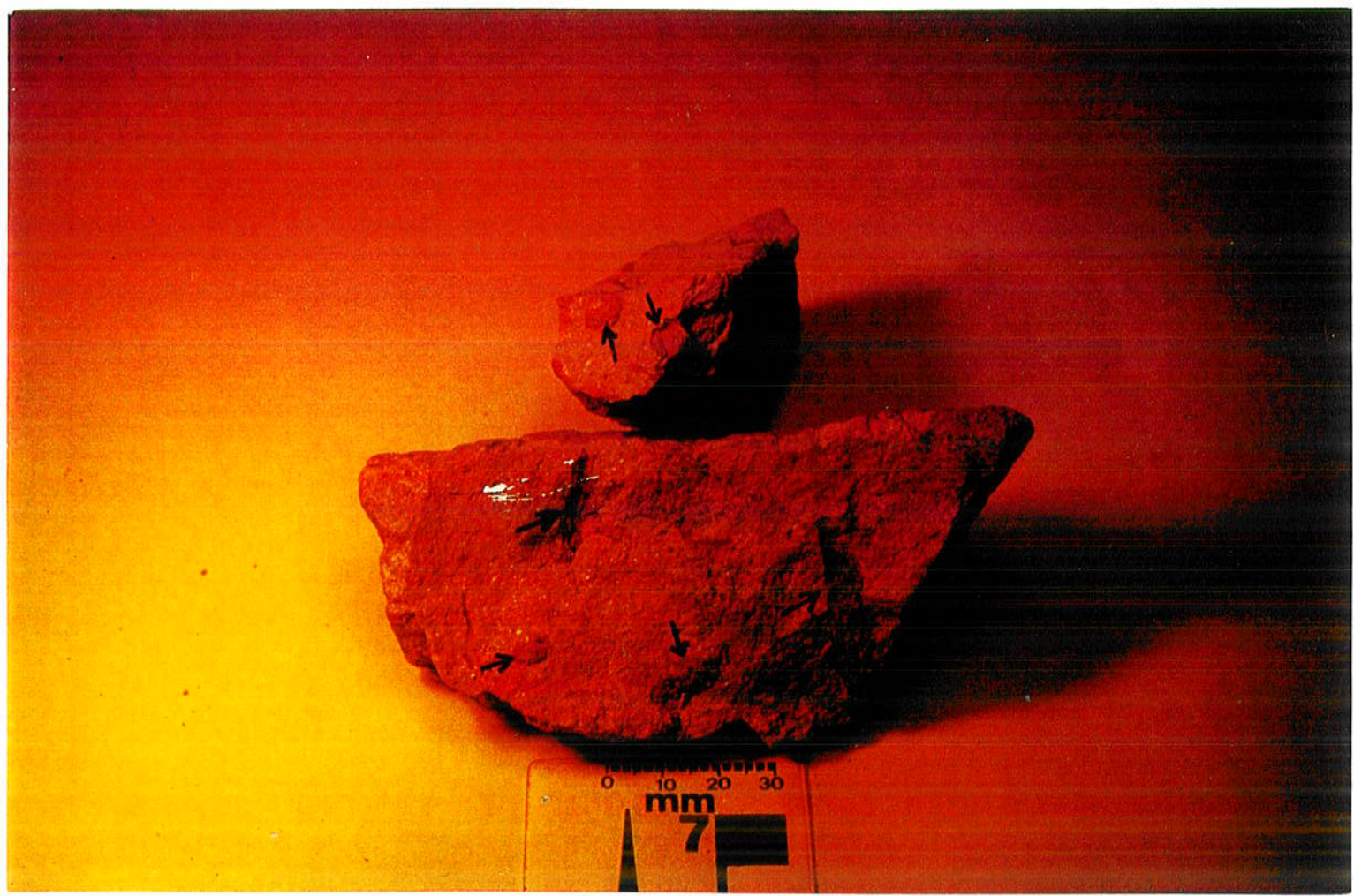

Figura 8: Lama da Formação Alexandra com marcas de tubos. Afloramento situado nas proximidades da PR 508 (ponto 12.2.92-06) 

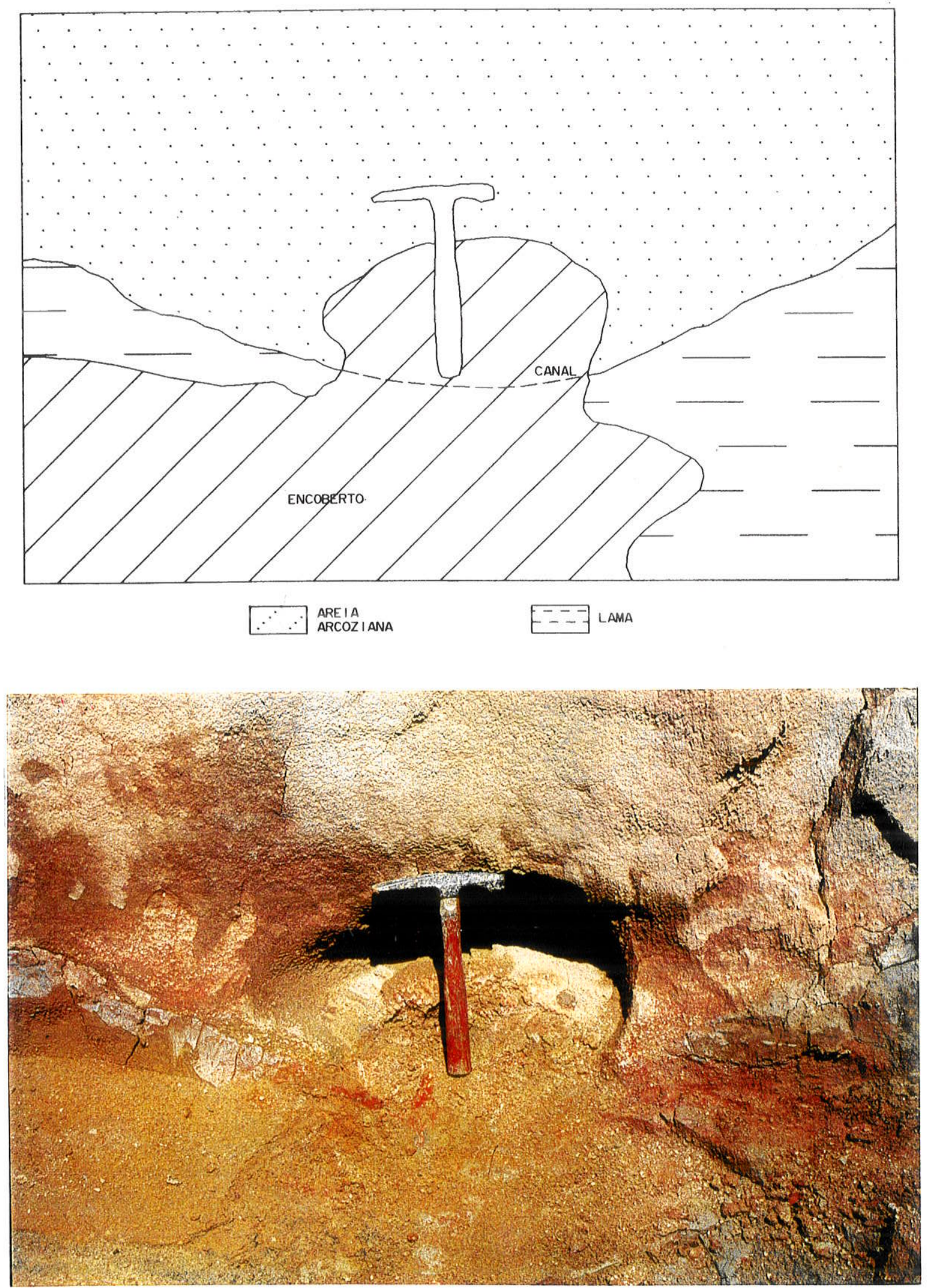

Figura 9: Topo de camada de lama da Formação Alexandra contendo canal raso preenchido por areia arcoziana. Afloramento situado próximo à PR 508 (ponto 29.10.91-02) 
Como as lamas, as areias também podem ser encontradas em camadas de poucos centímetros até 1,50 metros, ou preenchendo canais no topo das camadas argilosas (Fig. 9). Como estruturas sindeposicionais, aparecem estratificações planoparalelas ou incipientes cruzadas tabulares e de escavação e preenchimento (Fig. 10). Normalmente ocorre granodecrescência ascendente nessas camadas, em alguns casos gradando até areia fina ou argila. Estruturas erosivas como canais puderam ser encontradas nos contatos de camadas de areia com lama, onde é muito comum a presença de pelotas de argila na base das camadas arenosas, quase no contato com a camada inferior argilosa, indicando processo de canibalismo.

Em afloramento localizado à frente da seção-tipo (Fig. 11), foram encontradas algumas estruturas de boudinage sedimentar que podem ter sido originadas por escorregamento ou deslizamento pós-deposicionais (Suguio, 1980). Pode-se notar nesta figura o rompimento por tensão de algumas camadas mais argilosas (lamas).

Os finos apresentam-se como um material bastante plástico, de cor cinza e sem estruturas visíveis. É comum a presença de micas e minerais pesados e apesar de não ocorrerem grânulos de quartzo ou feldspatos, como nos lamas, sua origem deve ser a mesma desses sedimentos, pois a fração areia é abundante nos finos (cerca de $20 \%$ - vide ANEXO 1), o que implicaria em competência de transporte, como no fluxo de lama.

Próximo a região de Alexandra, há uma única ocorrência de rudáceos (ponto 12.2.92-06, Fig. 12). Trata-se de cascalho sustentado por clastos, onde predominam seixos de quartzo, bastante arredondados, imbricados e com granodecrescência ascendente. A matriz é composta predominantemente de areia arcoziana, com granulometria média a grossa, de grãos pobremente selecionados e com pouca argila. Em meio ao cascalho ocorre uma lente de finos. O conglomerado é a camada basal deste pacote sedimentar que ocorre sobre o granito bastante alterado. 


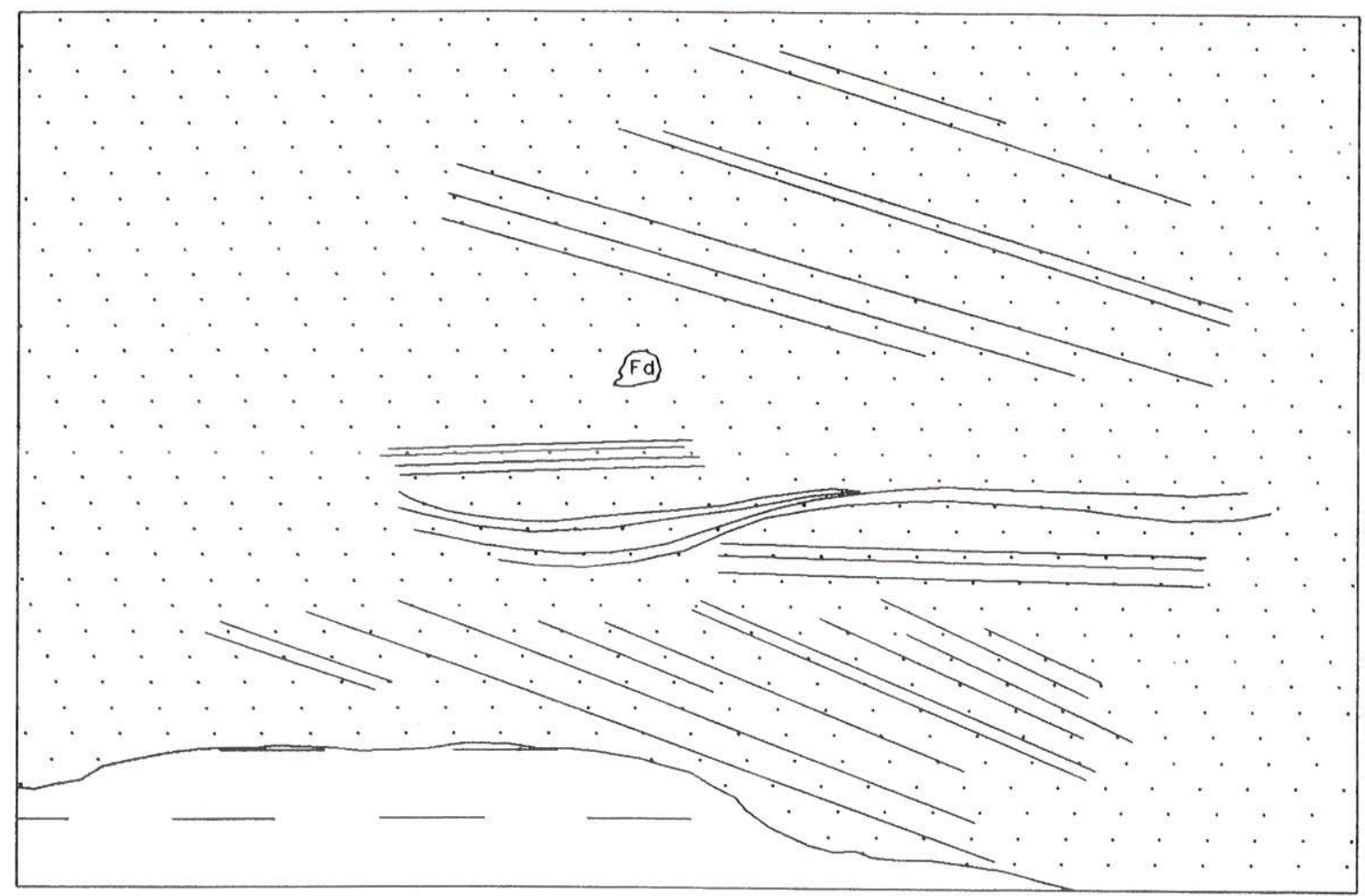

$\therefore$ AREIA

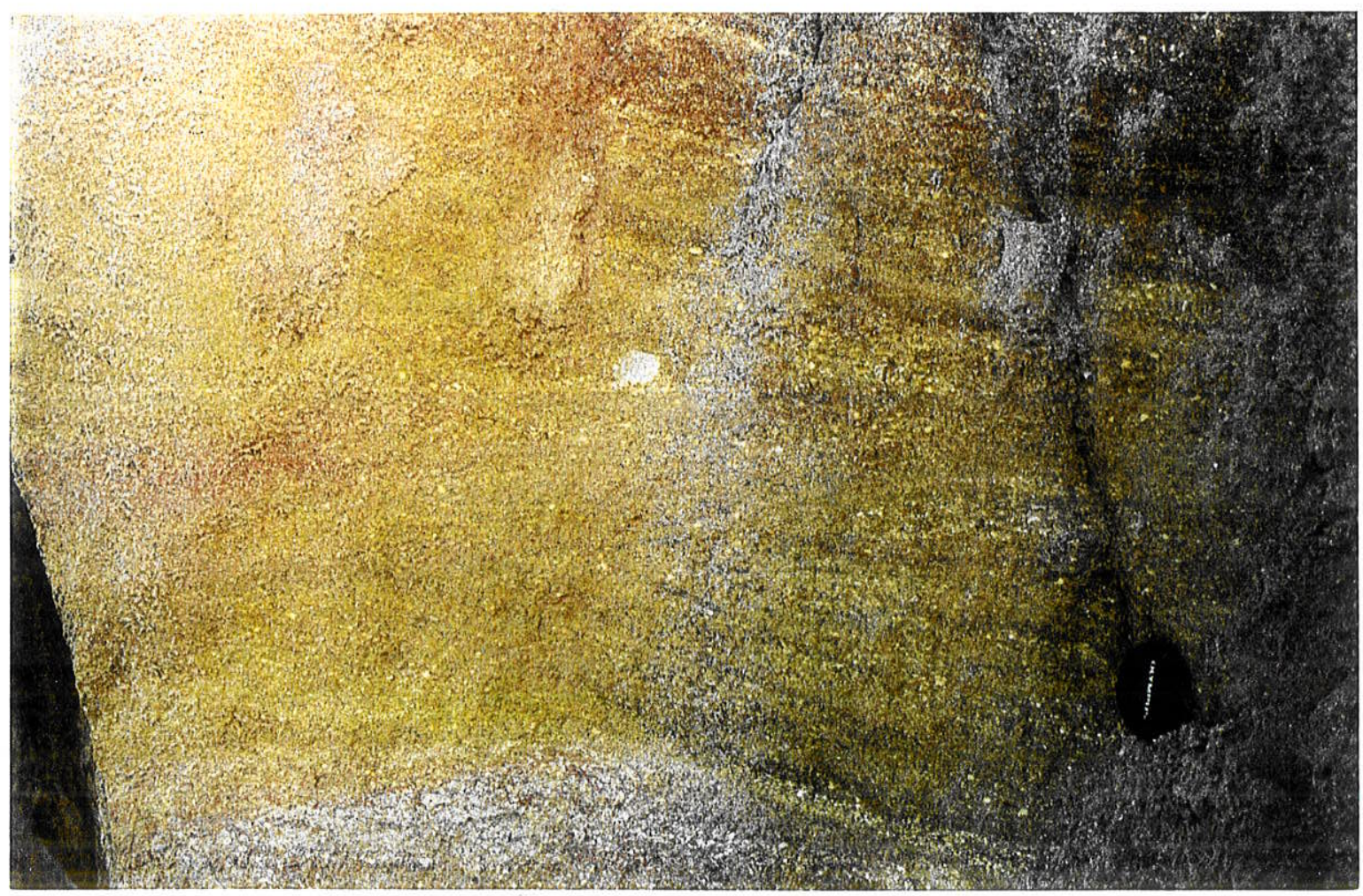

Figura 10: Areia arcoziana da Formação Alexandra contendo estratificações cruzadas tabulares e de escavação e preenchimento. Afloramento às margens da PR 508 (ponto 22.10.91-02) 

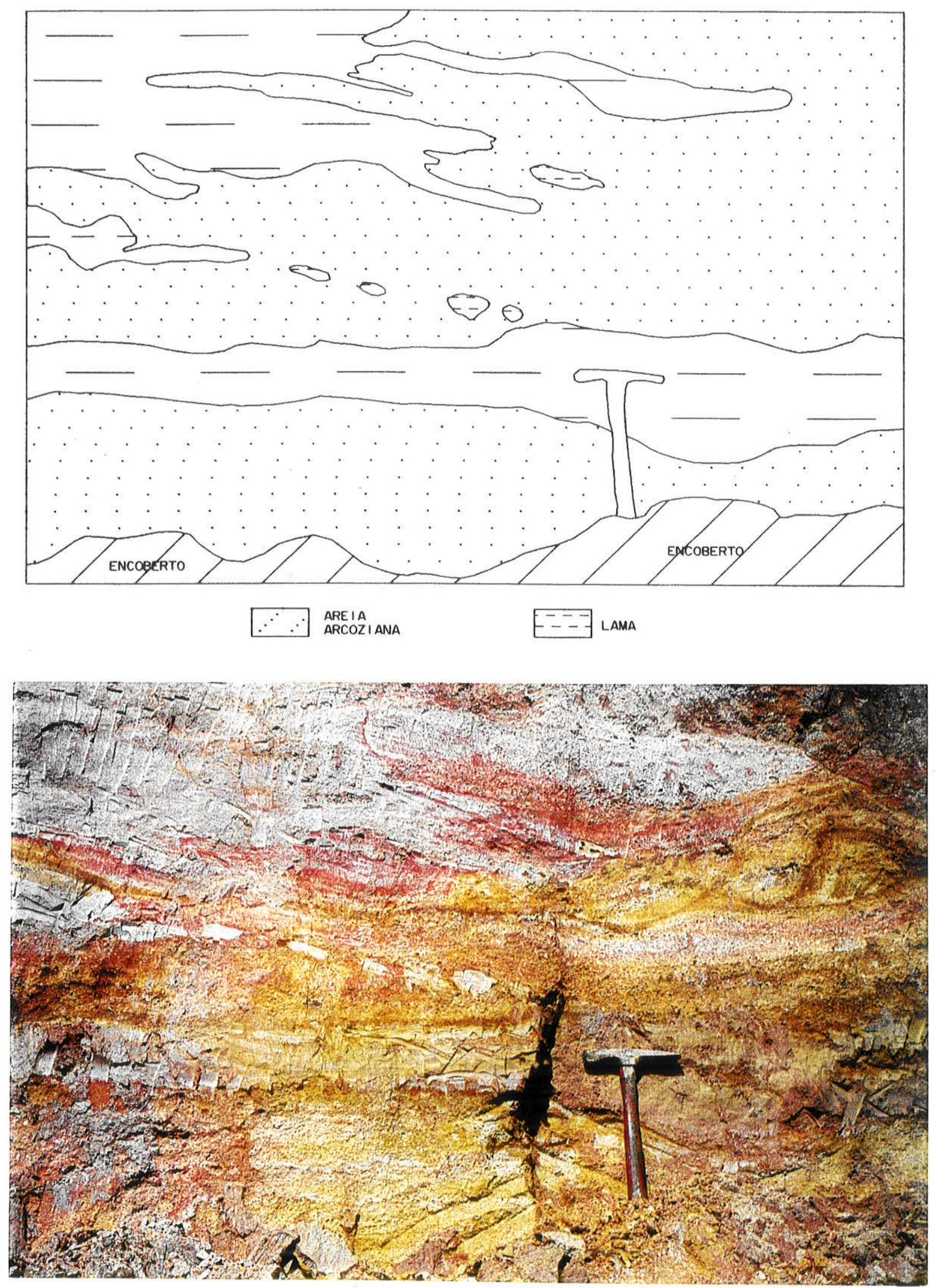

Figura 11: Camadas de areia arcoziana e lamas da Formação Alexandra apresentando estruturas de boudinage sedimentar. Afloramento situado em frente à seçãotipo (ponto 20.2.92-01). 
Na região próxima à cidade de Guaraqueçaba é mais comum a presença de sedimentos rudáceos, principalmente na estrada que liga a PR 405 à localidade de Batuva (Fig. 13), onde esta litologia é a característica mais marcante nos afloramentos. Cascalhos oligomíticos sustentados por clastos são predominantes, ocorrendo em taludes da estrada de até $3,20 \mathrm{~m}$ de altura. Os clastos são de quartzo, com tamanhos variáveis desde seixos a matacões, que encontram-se bem arredondados e imbricados, apresentando-se em alguns casos com granodecrescência ascendente e estratificação cruzada incipiente. A matriz é composta de areia arcoziana, com pouca argila, de cores branca e rosa. Localmente a matriz pode ter textura mais argilosa. A fração areia da matriz é de granulometria grossa, os grãos são moderadamente selecionados e predominam grânulos de quartzo subarredondados a arredondados.

Em meio ao cascalho sustentado por clastos ocorrem paleocanais preenchidos por lamas ou areia arcoziana. Alguns desses paleocanais possuem até $1,20 \mathrm{~m}$ de largura. Também neste cascalho foi encontrado lente de lama (Fig. 14), que pode tratar-se de estrutura de sobrecarga causada por peso de pacotes sedimentares sobrepostos sobre a argila que tem menor densidade do que o cascalho.

Cascalhos sustentados por matriz também ocorrem próximos à PR 405, após o entroncamento da estrada que leva à Batuva, em direção à cidade de Guaraqueçaba. Os clastos são de quartzo, variando de grânulos a seixos, são angulares a arredondados, encontram-se dispostos aleatoriamente na matriz e apresentam incipiente granodecrescência ascendente. A matriz é arcoziana, de granulometria grossa e sem seleção, com grânulos de quartzo angulares e feldspatos bastante alterados.

Camadas de lamas e areias arcozianas encontram-se intercaladas em ambos cascalhos que foram descritos (Fig. 15). As areias arcozianas, além de apresentarem incipientes estratificações cruzadas, é comum estarem preenchendo canais escavados nos cascalhos ou nas camadas de lamas. As características texturais e mineralógicas desses sedimentos são as mesmas que já foram descritas para os sedimentos encontrados nas proximidades da PR 508. 

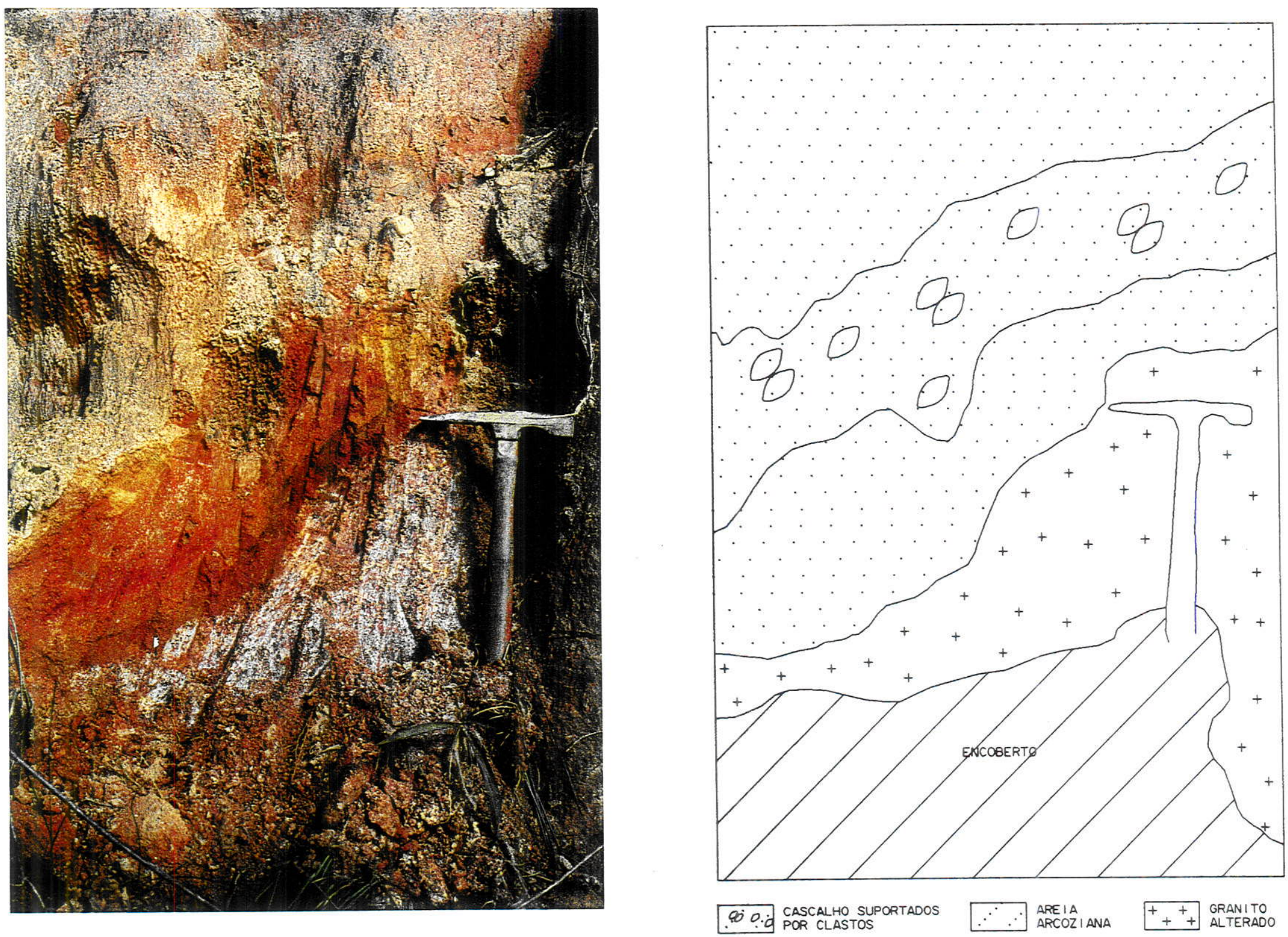

Figura 12: Depósito com ocorrência de rudáceos e areia arcosiana da Formação Alexandra sobre granito alterado. Afloramento situado à margem da PR 508 (ponto 12.2.92-06). 


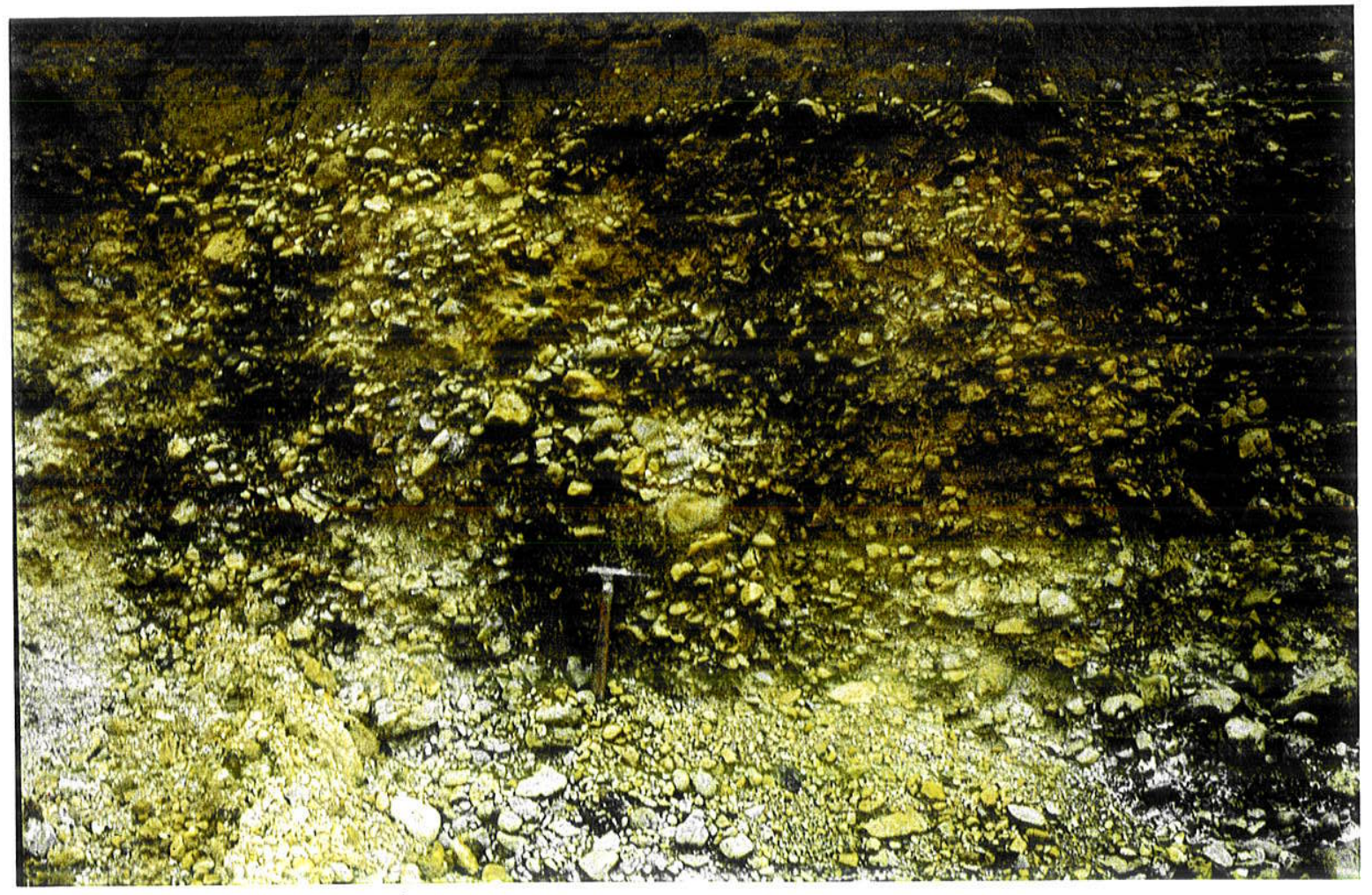

Figura 13: Depósito de cascalho sustentado por clastos da Formação Alexandra apresentando imbricações e estratificações cruzadas tabulares. Afloramento situado às margens da estrada para Batuva (ponto 22.1.92-02). 

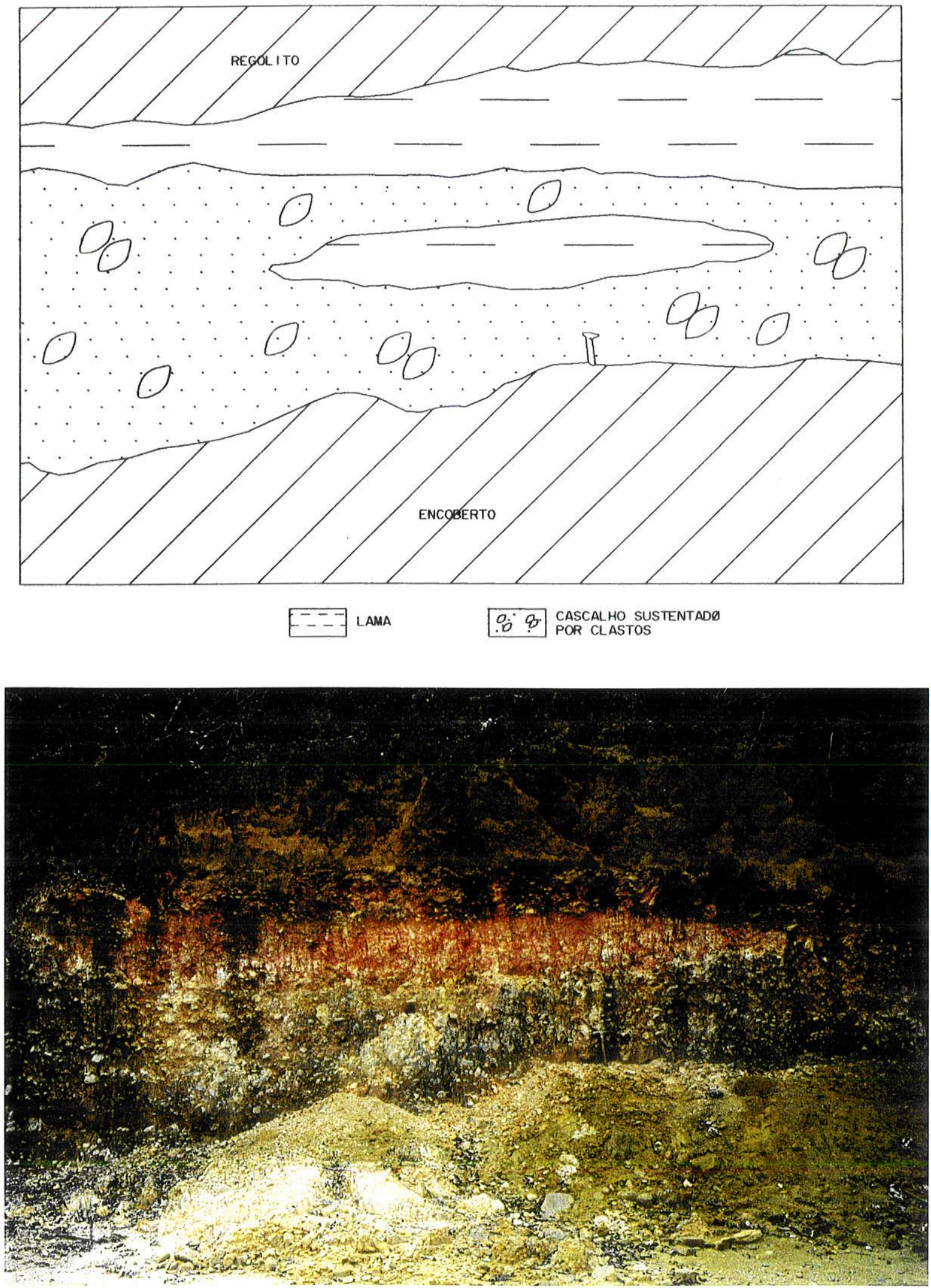

Figura 14: Depósito de cascalho sustentado por clastos da Formação Alexandra, contendo lente de lama. Afloramento situado à margem da estrada para Batuva (ponto 13.2.92-01) 

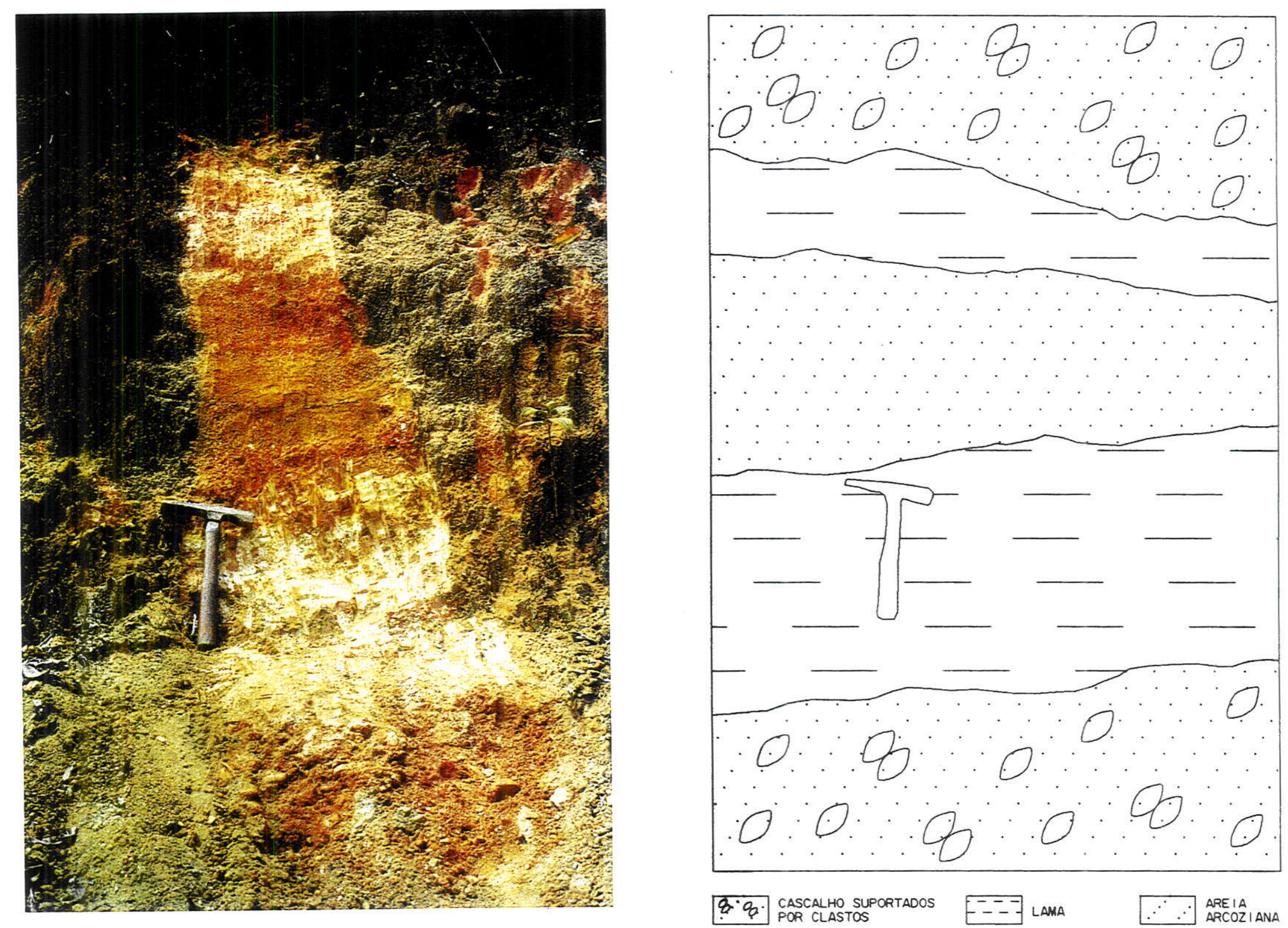

Figura 15: Depósitos da Formação Alexandra compostos de areias arcozianas e lamas intercaladas com cascalhos sustentados por clastos. Afloramento situado à margens da estrada para Batuva (ponto 13.2.92-01). 
Em afloramento da Formação Alexandra na estrada para Batuva (ponto 22.1.92-02), constatou-se a presença de estruturas de sobrecarga com penetração de lobos de areia arcoziana na camada de lama subjacente (Figs. 16 e 17). Em meio à lama foram encontrados pseudonódulos de areia, que sugerem a separação dos lóbos arenosos de sua camada original, causado pela sobrecarga desta sobre a camada inferior argilosa, aliando-se a isto a menor densidade e maior plasticidade da camada de lama. Esta estrutura tem caráter deformacional e não erosivo, o que indicaria que a camada arenosa foi depositada logo em seguida à deposição da lama que encontravase ainda em estado liquefeito.

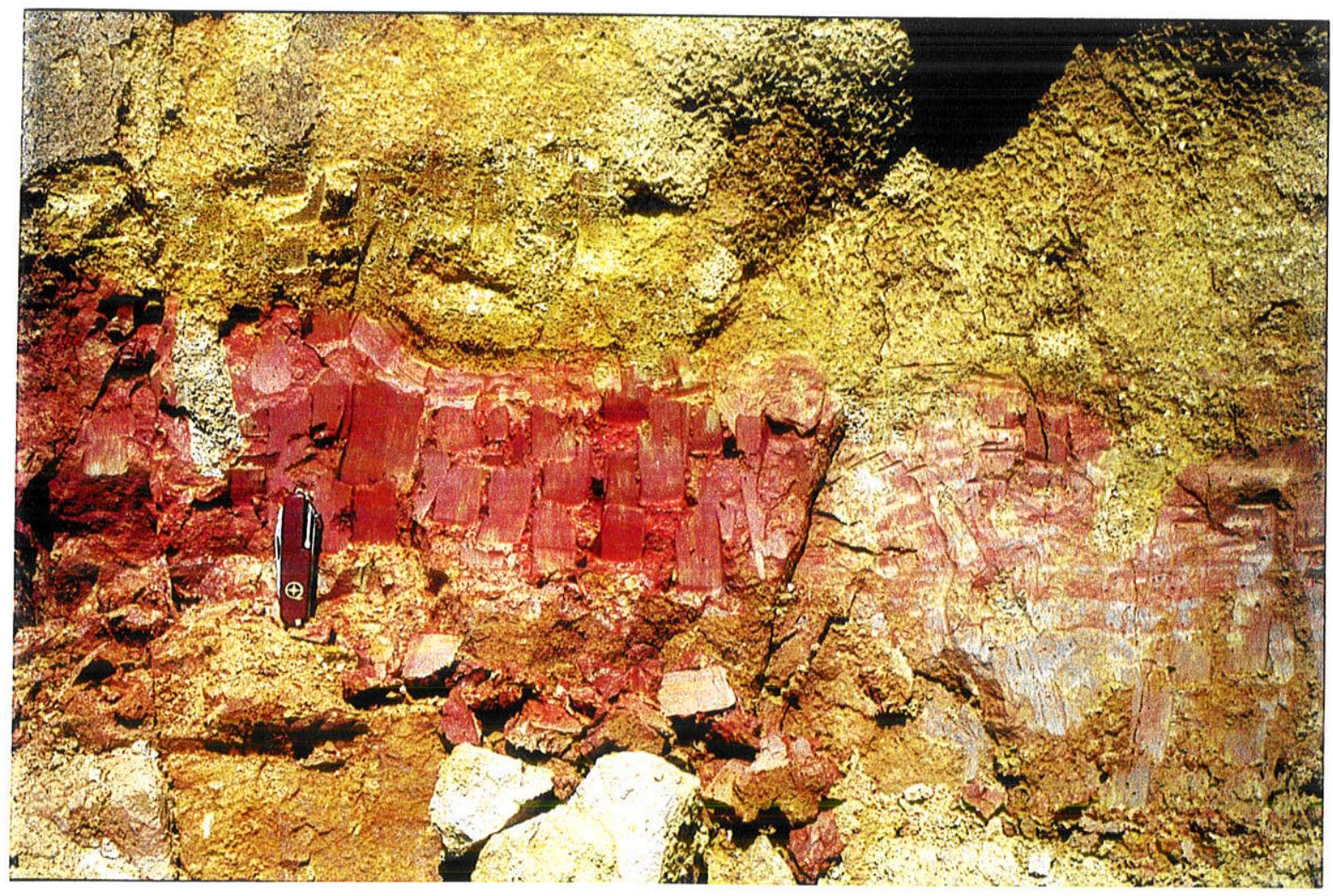

Figura 16: Depósitos de areia arcoziana e lama da Formação Alexandra, apresentando lobos de areia em meio à lama, causados por estruturas de sobrecarga. Na porção inferior direita da foto, na camada lamítica, tem-se a presença de pseudonódulos de areia. Afloramento situado à margem da estrada para Batuva (ponto 22.1.92-02) 


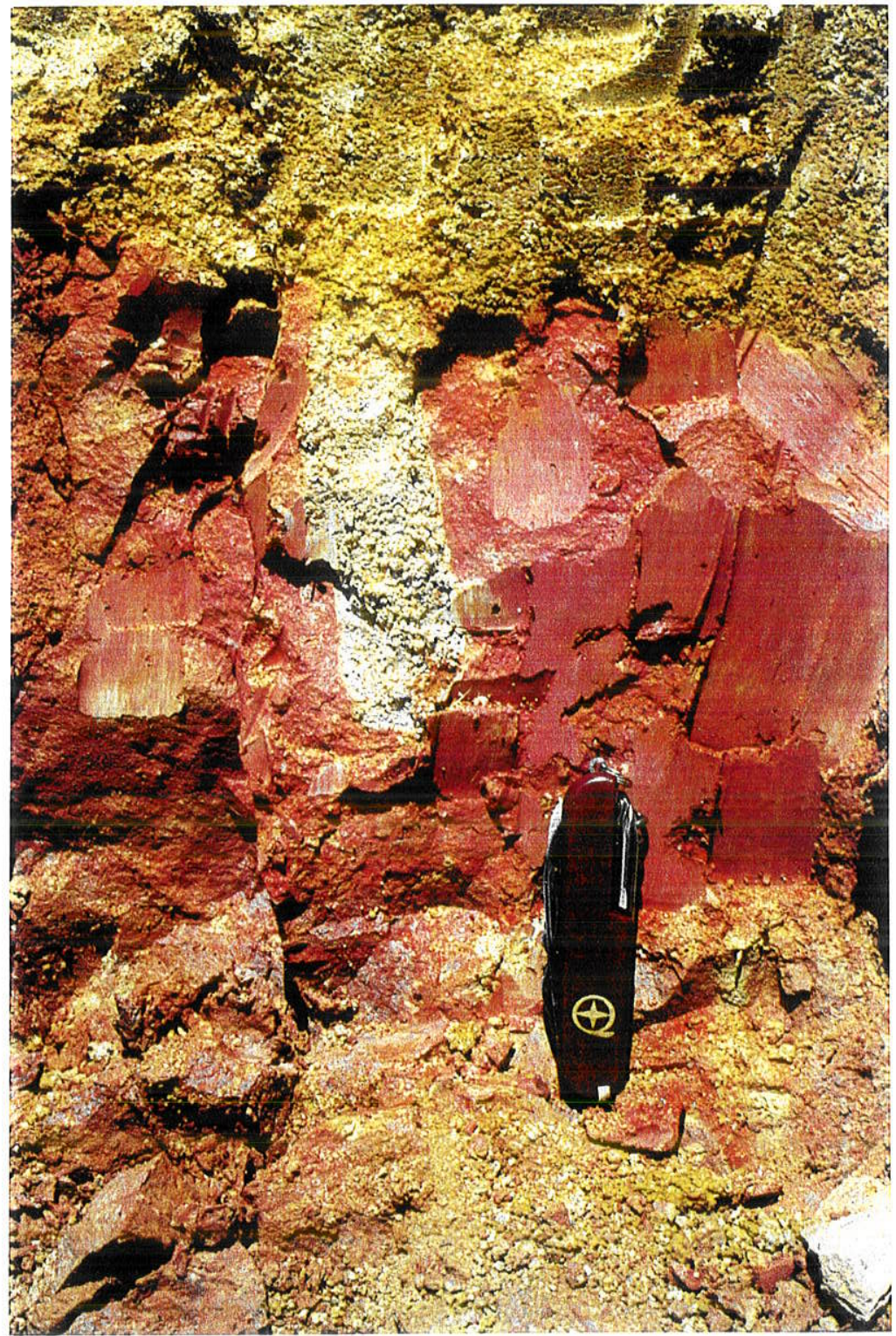

Figura 17: Detalhe da figura anterior, mostrando lobo arenoso sobre a lama.

\subsubsection{Seção-Tipo}

A seção-tipo da Formação Alexandra que foi descrita por Angulo (1995), está situada na BR 277 (estrada Curitiba-Paranaguá) onde se inicia a PR 508 (estrada Alexandra-Matinhos). A cerca de 150 metros desta seção encontra-se o perfil $\mathrm{n}^{\circ} 3$ do trabalho de Bigarella et al. (1959), onde se originou o nome desta formação.

Na seção-tipo descrita por Angulo (1995) (Fig. 3), a parte inferior é composta predominantemente por "arcóseos cascalhentos", de cor cinza-esverdeada, 
com abundantes grânulos e seixos de até $8 \mathrm{~mm}$ de diâmetro, constituídos de quartzo e feldspato. Tanto os grânulos como as partículas menores da fração areia são angulares. Esses “arcóseos” estão dispostos em leitos horizontais de vários decímetros de espessura e apresentam gradação normal, tendo localmente "laminação cruzada acanalada" de até $30 \mathrm{~cm}$ de espessura.

$\mathrm{Na}$ parte superior do perfil predominam lamas que apresentam teores variáveis de grãos de areia e grânulos. Normalmente ocorrem seqüências de poucos centímetros de lama com areias arcozianas. Estas podem também se encontrar em canais escavados nos sedimentos síltico-argilosos. As estruturas encontradas foram gradação normal e bolas de argila.

$\mathrm{Na}$ parte média do afloramento ocorre uma "camada linhítica" de $80 \mathrm{~cm}$. de espessura, de cor preta e marrom que está intercalada entre camadas de lamas.

As descrições realizadas neste trabalho, diferem apenas na parte superior do perfil, em relação à descrição de Angulo (1995). Devido a um pequeno deslizamento nessa porção do perfil, ficou à mostra uma camada mais arenosa do que a originalmente descrita por aquele autor (Figs. 18 e 19).

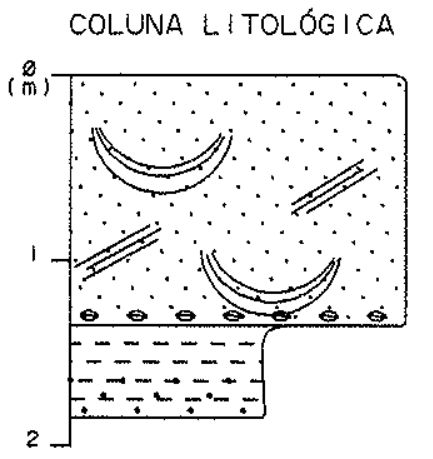

DESCRICĀO

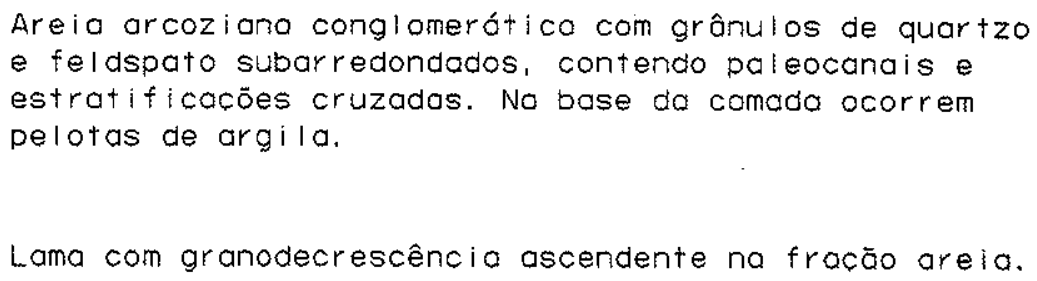

Figura 18: Esquema das camadas de topo da seção-tipo da Formação Alexandra. Afloramento situado à margem da BR 277, onde se inicia a PR 508. 


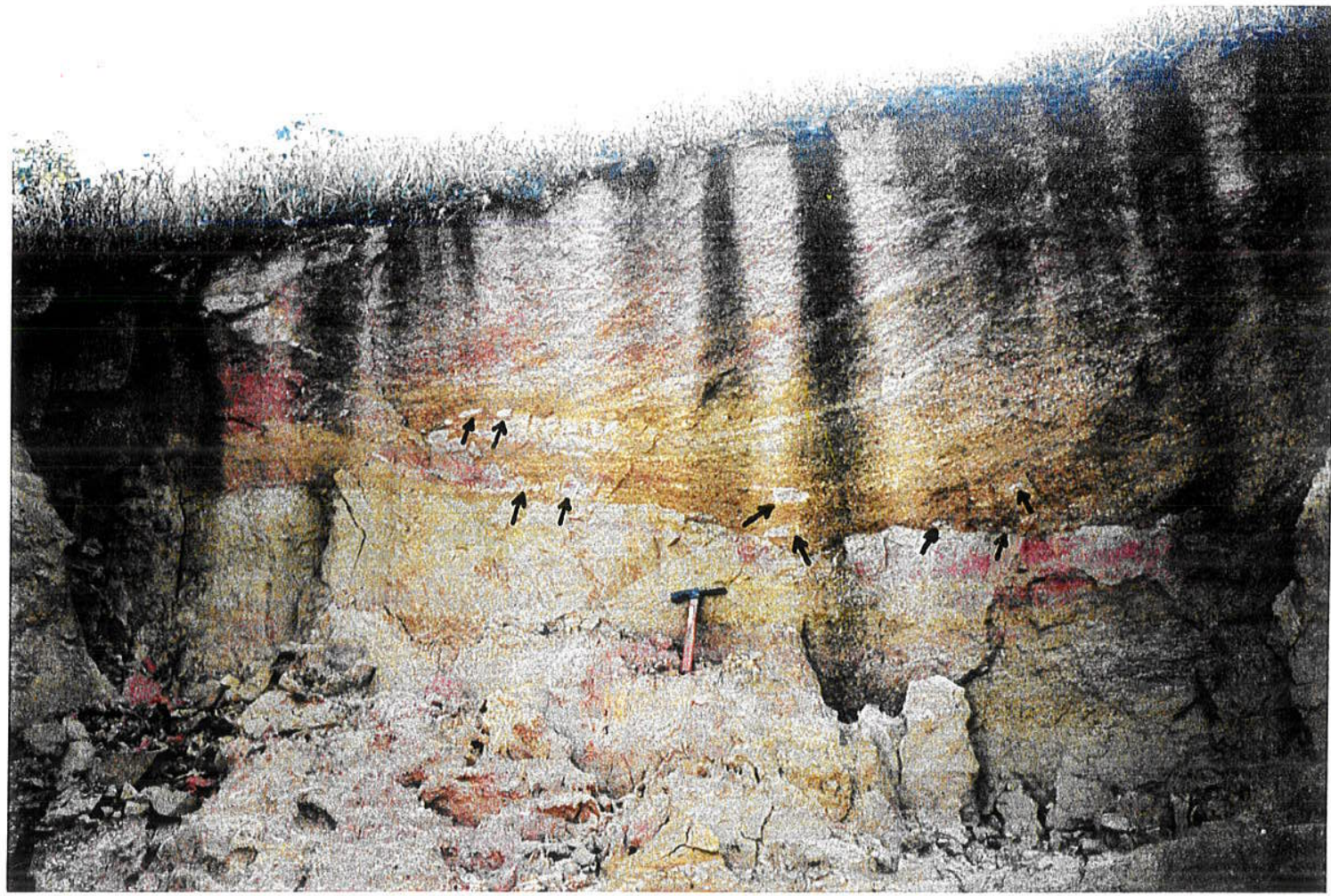

Figura 19: Camada do topo da seção-tipo da Formação Alexandra, apresentando estrutura de escavação e preenchimento e pelotas de argila (indicadas pelas setas).

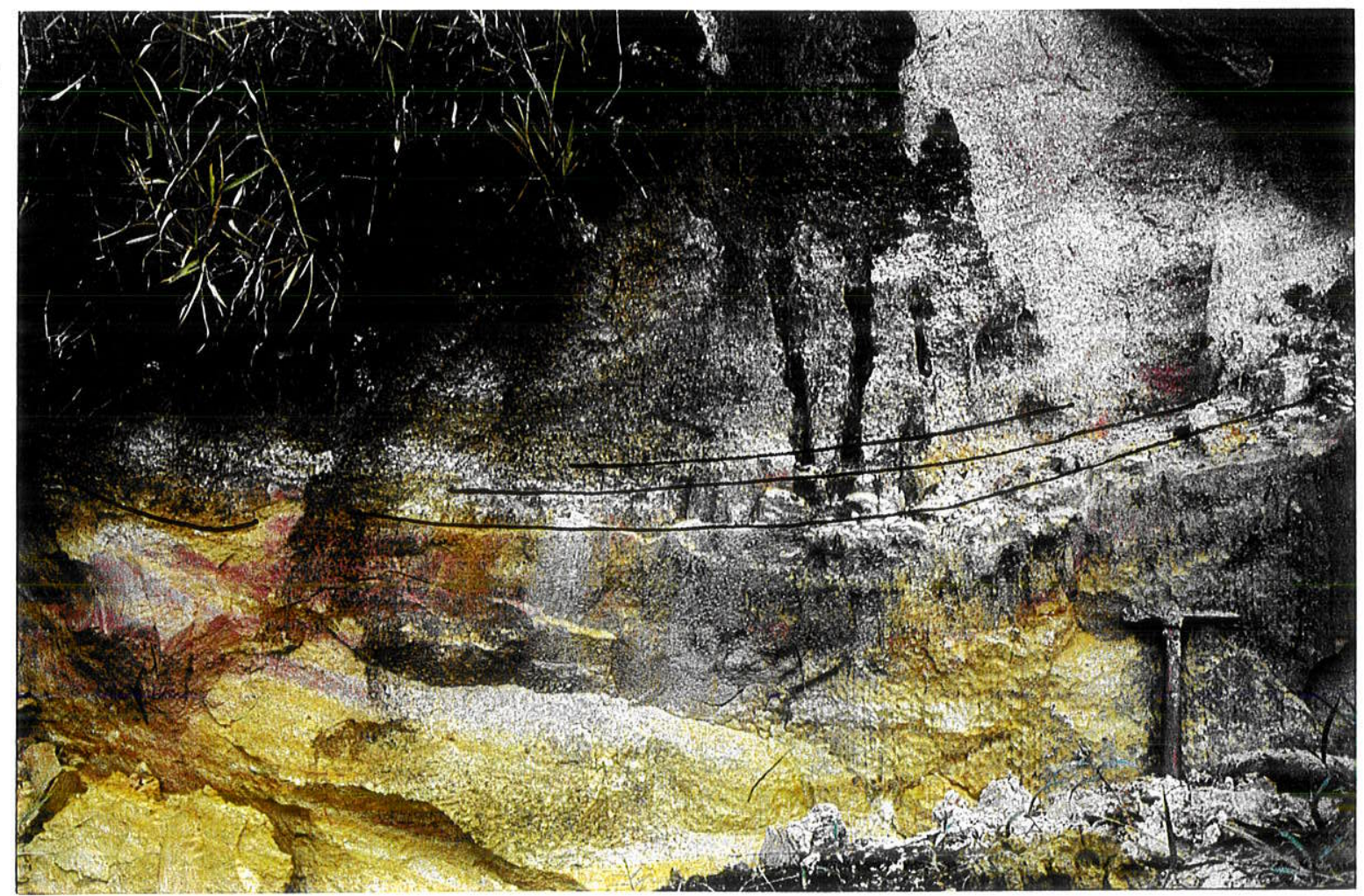

Figura 20: Camada de areia arcoziana depositada em paleocanal na camada de lama. Afloramento situado à margem da PR 508 (ponto 22.10.91-03). 
Trata-se de uma camada de areia arcoziana com 1,36 $\mathrm{m}$ de espessura, possui grânulos angulares de quartzo e feldspatos, estes bastante alterados. Foram encontradas estruturas sindeposicionais, como estratificação cruzada tabular e de escavação e preenchimento. Estas podem alcançar até $2,50 \mathrm{~m}$ de largura, como pode ser observado na Fig. 19. Também foram encontradas estruturas de escavação e preenchimento, como pequenos canais (cerca de $20 \mathrm{~cm}$ de largura) que ocorrem no topo de camada lamítica, preenchidos por areia arcoziana e pelotas de argila que foram encontradas na base da camada arenosa, indicando processo de canibalismo.

Dois afloramentos situados próximos à PR 508 merecem destaque neste trabalho como seções de referência. A primeira situa-se à margem da PR 508 (ponto 22.10.91-03), distando cerca de $5 \mathrm{~km}$ da seção-tipo. Tem características sedimentológicas similares à seção-tipo, inclusive na camada de topo que foi descrita acima (Figs. 20 e 21). A segunda seção de referência também se encontra à margem da PR 508, a pouco menos de $3 \mathrm{~km}$ da seção-tipo e já foi descrita no item anterior (ponto 12.2.92-06). Esta seção (Fig. 12) se diferencia das outras seções já descritas para a região da PR 508 por conter uma camada de lama com marcas de tubo e uma camada de cascalhos sustentados por clastos. Este afloramento também foi o único a apresentar na base rochas alteradas do embasamento cristalino

$\mathrm{Na}$ região de Guaraqueçaba foi escolhida uma seção de referência (Fig. 22), que se distingue das seções da PR 508 pelo predomínio de cascalhos sustentados por clastos sobre outros sedimentos. Localmente, em meio aos depósitos de cascalhos, foram encontradas camadas de areia arcoziana e lama, com características sedimentológicas semelhantes aos depósitos já descritos das proximidades da PR 508. 


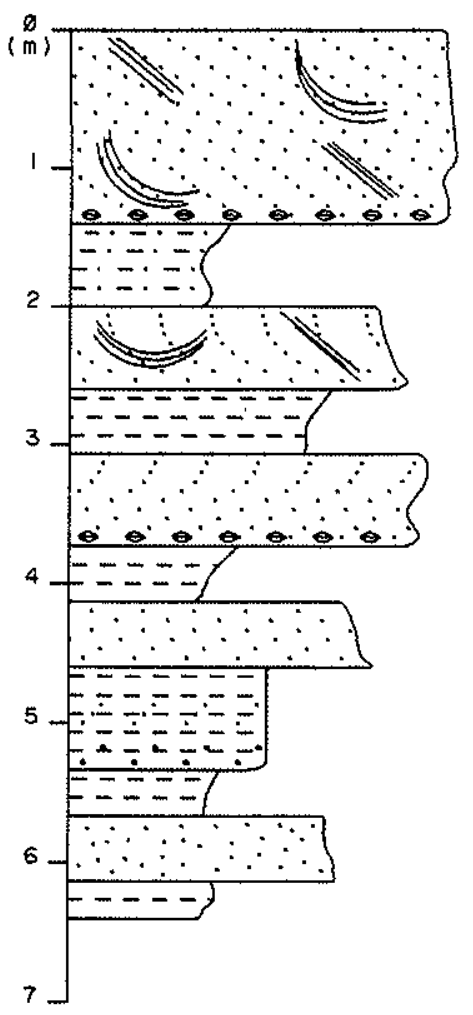

Areia arcoziana com grânulos de quartzo e feldspato

alterados. Săo encontradas pelotas de argila,

estrotificacão cruzada e poleocanais

Lama contendo argila de cor violeta, grânulos de

quartzo, feldspoto e muscovita.

Areia arcoziana com poleocanais.

Lama com lentes arenosas.

Areia arcozlana com pelotas de argila.

Lama com argi las de cores cinzo, rosa e branca.

Areia arcoziana com grânulos de quartzo e feldspato alterados.

Lama com granodecrescência ascendente na fracão arela.

Lama com argilas de cores cinza, rosa e branca.

Areia arcoziana.

Lamo com argila de cor cinza escura.

Figura 21: Depósitos intercalados de lamas e areias arcozianas da Formação Alexandra. Afloramento situado à margem da PR 508 (ponto 22.10.91-03).

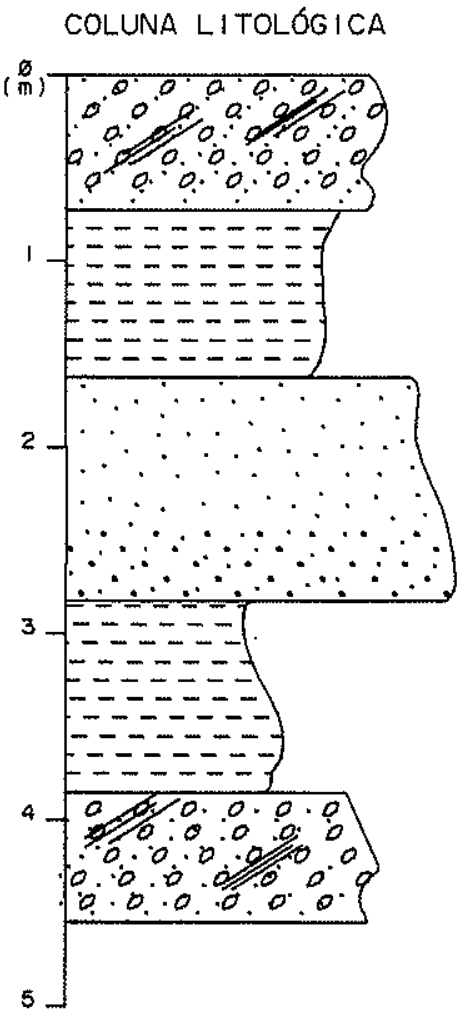

DESCRICĀO

Cascalho suportado por clastos bem arredondados, com imbricacōes e estratificacōes cruzadas, em matriz argilo-arenosa.

Lama com fração de oreia grossa.

Areia arcoziana com granulos de quartzo e feldspato alterados subangulares. Ocorre granodecrescência ascendente.

Lama com argila em cores branca e rosa, fracão de areia

fina e grânulos subangulares de quartzo dispersos na matriz.

Cascalho sustentado por clastros bem arredondados, com imbricacōes e estratificacōes cruzadas, em matriz argilo-arenosa.

Figura 22: Depósitos sedimentares da Formação Alexandra, com camadas de lamas e areias arcozianas intercaladas com cascalhos sustentados por clastos. Afloramento situado próximo à localidade de Batuva (ponto 13.2.92-01). 


\subsubsection{Leques Aluviais Quaternários}

Como já foi referido anteriormente, os leques aluviais encontrados na região do litoral paranaense receberam diferentes denominações em trabalhos prévios, tais como depósitos de piemonte (Bigarella, 1964); depósitos terrígenos (Bigarella, 1965); cones de dejeção (Fuck et al., 1969); coluviões de pé de relevo (Martin et al., 1988) e também como leques aluviais e cones aluviais (Angulo, 1995).

$\mathrm{Na}$ literatura os leques e cones aluviais são usados como sinônimos, sendo que Rapp \& Fairbridge (1968), utilizam o termo cone aluvial (alluvial cone) como uma acumulação de detritos formados por torrentes e fluxos de lama. Diferencia-se do cone de talus (talus cone) por ter um perfil geralmente côncavo do topo até a base, enquanto que o cone de talus possui perfil reto. Para este trabalho se utilizará os termos cone aluvial e leque aluvial como sinônimos.

Nas fotointerpretą̧ões, constatou-se que essas unidades possuem contornos nítidos, com perfil longitudinal côncavo, associadas às vertentes da Serra do Mar $\mathrm{e}$ com a presença de drenagem radial distributiva, típica de leques aluviais. Segundo Angulo (1995), a declividade média dos leques aluviais é de 2 a $20^{\circ}$, com exceção ao leque aluvial Cubatão que possui declividade menor que $1^{\circ}$. Este autor, através de observação das geoformas, distinguiu até três gerações de leques aluviais em algumas destas unidades, mas neste trabalho não foi possível confirmar esses resultados pela falta de bons afloramentos. Suas superficies apresentam-se bastante dissecadas e com canais fluviais principais bastante encaixados, mostrando retrabalhamento fluvial dos depósitos e sugerindo que os processos que originaram esta drenagem não são os mesmos que originaram os leques aluviais (Angulo, op. cit.).

Os leques aluviais receberam o nome do rio mais importante do vale em que foram encontrados, como rio Colônia Pereira (Fig. 23), rio Cambará, rio Cachoeirinha (Fig. 24), rio Cubatão (Fig. 25), rio Brejatuba, rio das Pombas (Fig. 26), rio Caovi e rio Miranda (Fig. 5), excetuando-se o leque aluvial Morretes (Fig. 27)que recebeu o nome da cidade onde se encontra. 


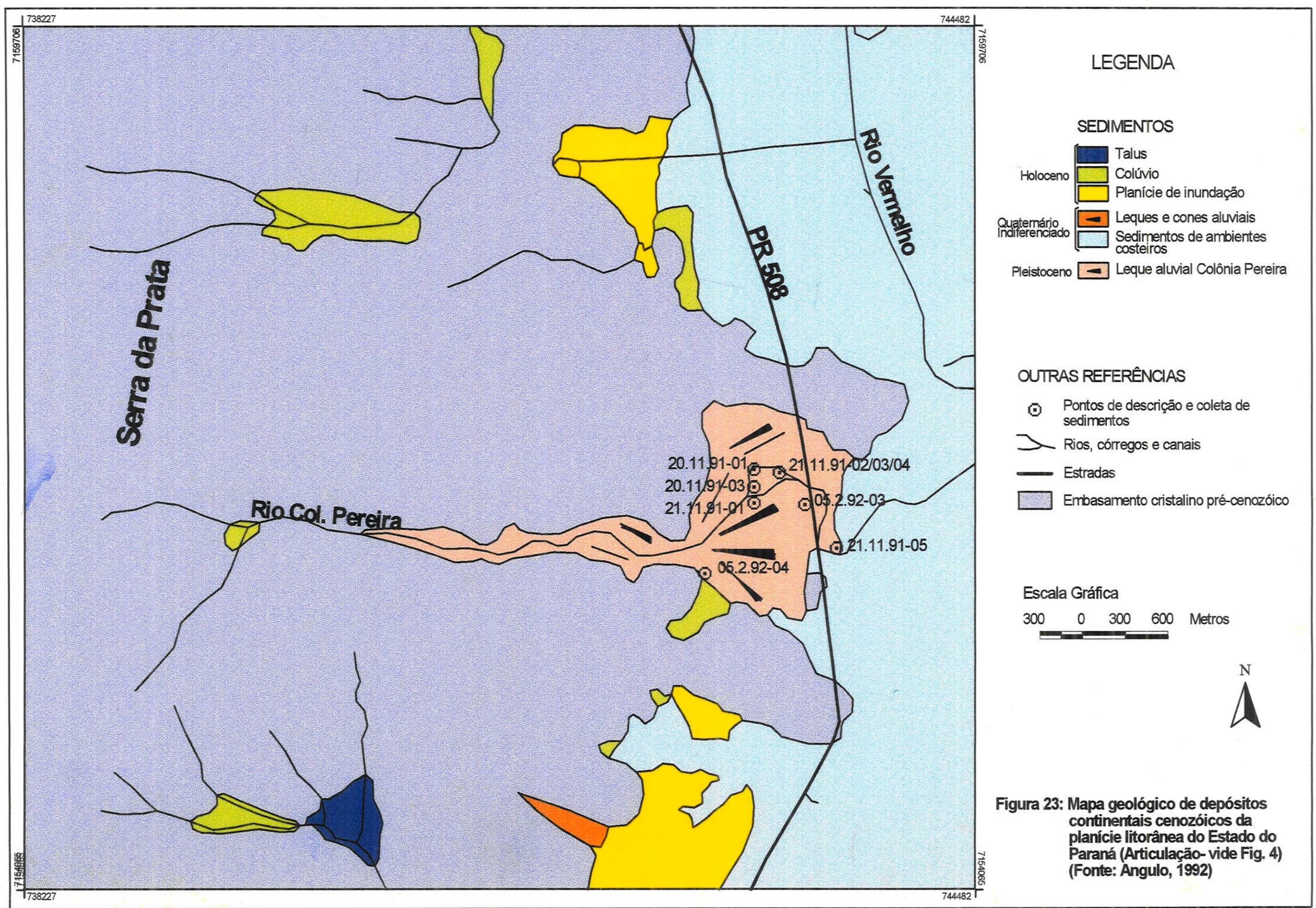




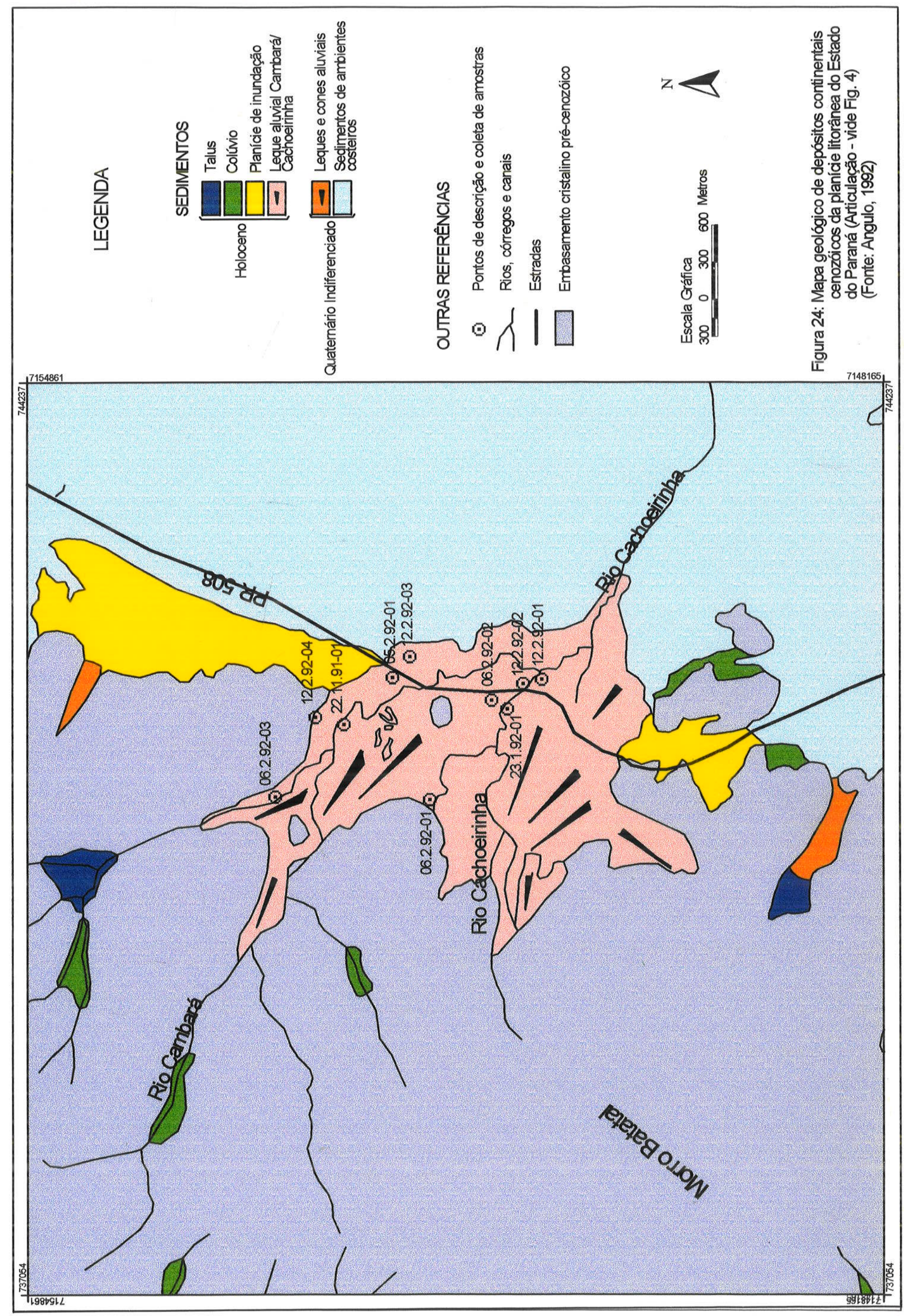




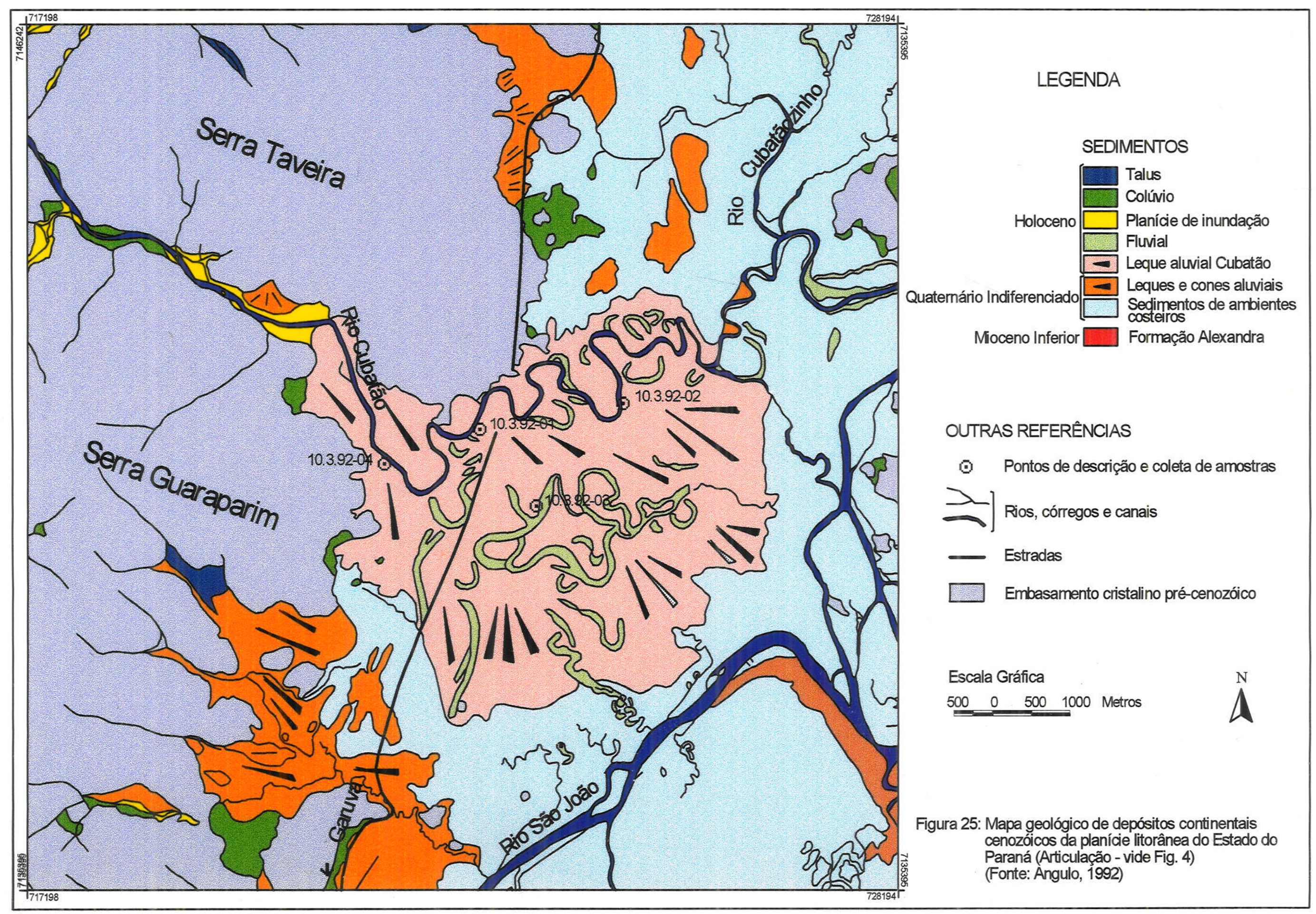




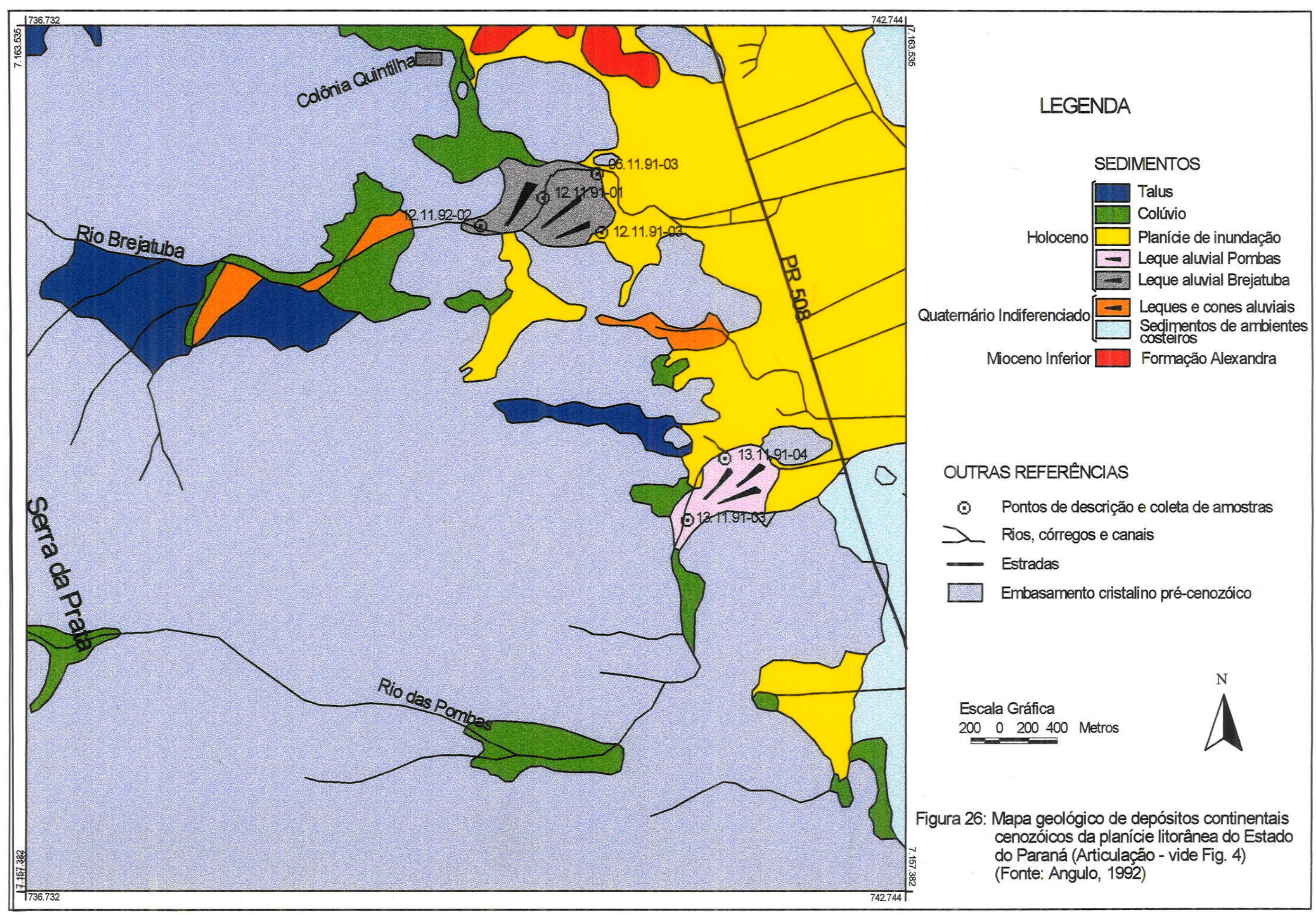




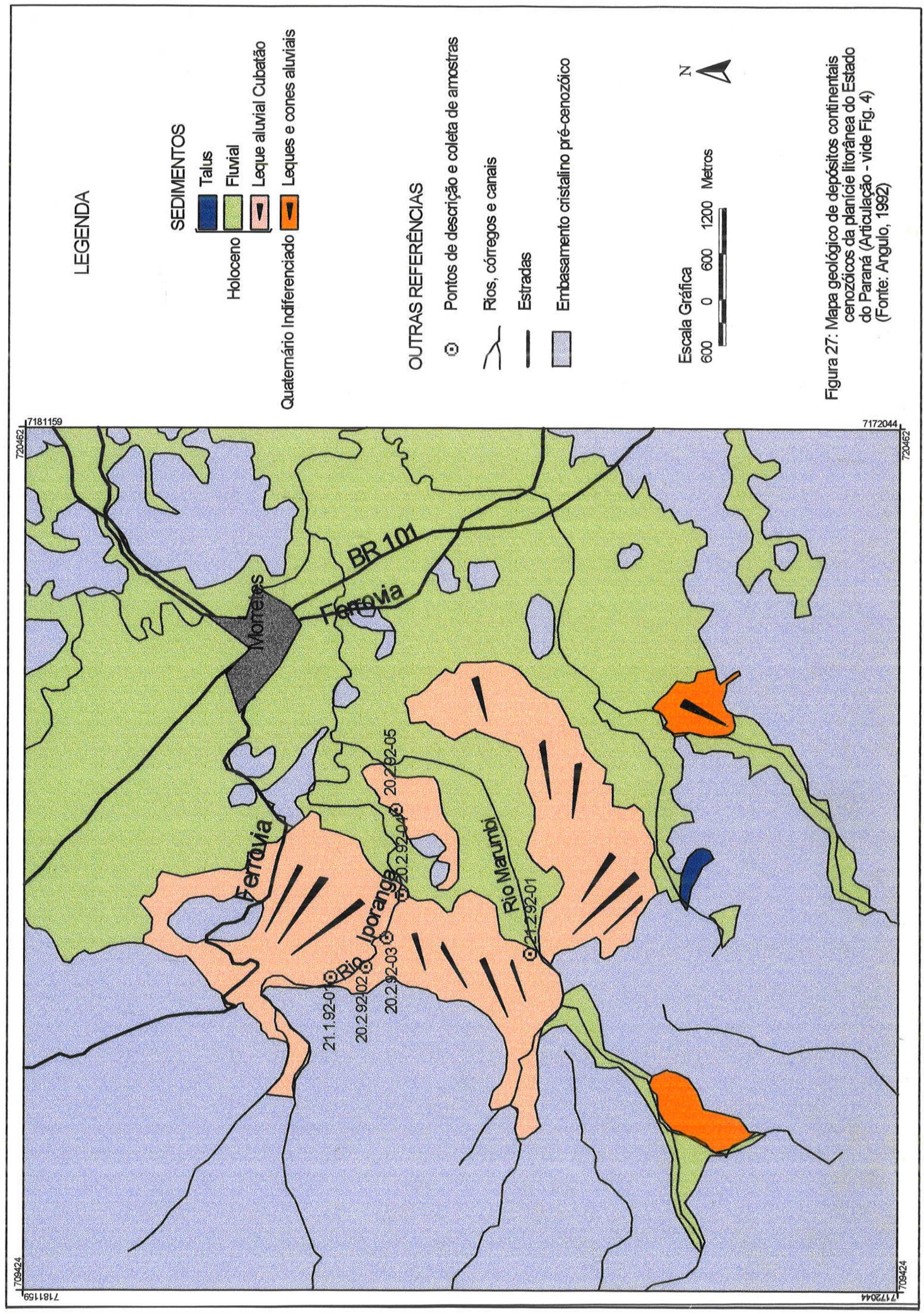




\subsubsection{Sedimentos}

Devido à características sedimentológicas distintas entre os leques aluviais, a descrição dos sedimentos será apresentada para cada unidade. 'Ressalta-se que os leques aluviais Brejatuba, Pombas, Caovi e Miranda, possuem características sedimentológicas e geomórficas bastante distintas dos outros leques, com perfil mais íngreme, menor variabilidade de tipos sedimentológicos e, talvez como característica mais distintiva, não apresentam as dissecações já descritas. Sendo assim, será apresentada apenas uma descrição dos sedimentos para esses leques aluviais.

\section{Leque Aluvial Colônia Pereira (Qcp)}

O leque aluvial Colônia Pereira é o mais interessante entre estas unidades, apresentando uma grande variedade de sedimentos e de estruturas sedimentares.

Predomina areia arcoziana e subsidiariamente lamas, ocorrendo também em menor proporção de cascalhos sustentados por matriz, cascalhos sustentados por clastos, areia fina e raramente finos.

As areias arcozianas foram encontradas em camadas de até $0,70 \mathrm{~m}$, chegando a ser cascalhosas em alguns depósitos (Figs. 28 e 29).

Compõem-se de quartzo, feldspatos, fragmentos líticos de granitos, micas e minerais pesados. Normalmente são muito mal selecionadas e em alguns depósitos apresentaram-se moderadamente selecionadas. Apenas os grãos de feldspato são arredondados, enquanto que os de quartzo e fragmentos líticos encontram-se subangulares a subarredondados. As estruturas de escavação e preenchimento com estratificações cruzadas são estruturas sedimentares muito comuns nesses depósitos, ocorrendo também estratificações plano-paralelas e cruzadas tabulares e granodecrescência ascendente.

Em um afloramento (Fig. 30) foi encontrado bloco de lama bastante deformado no meio de areia arcoziana, que pode ter sido originado de forma similar às pelotas de argila. 

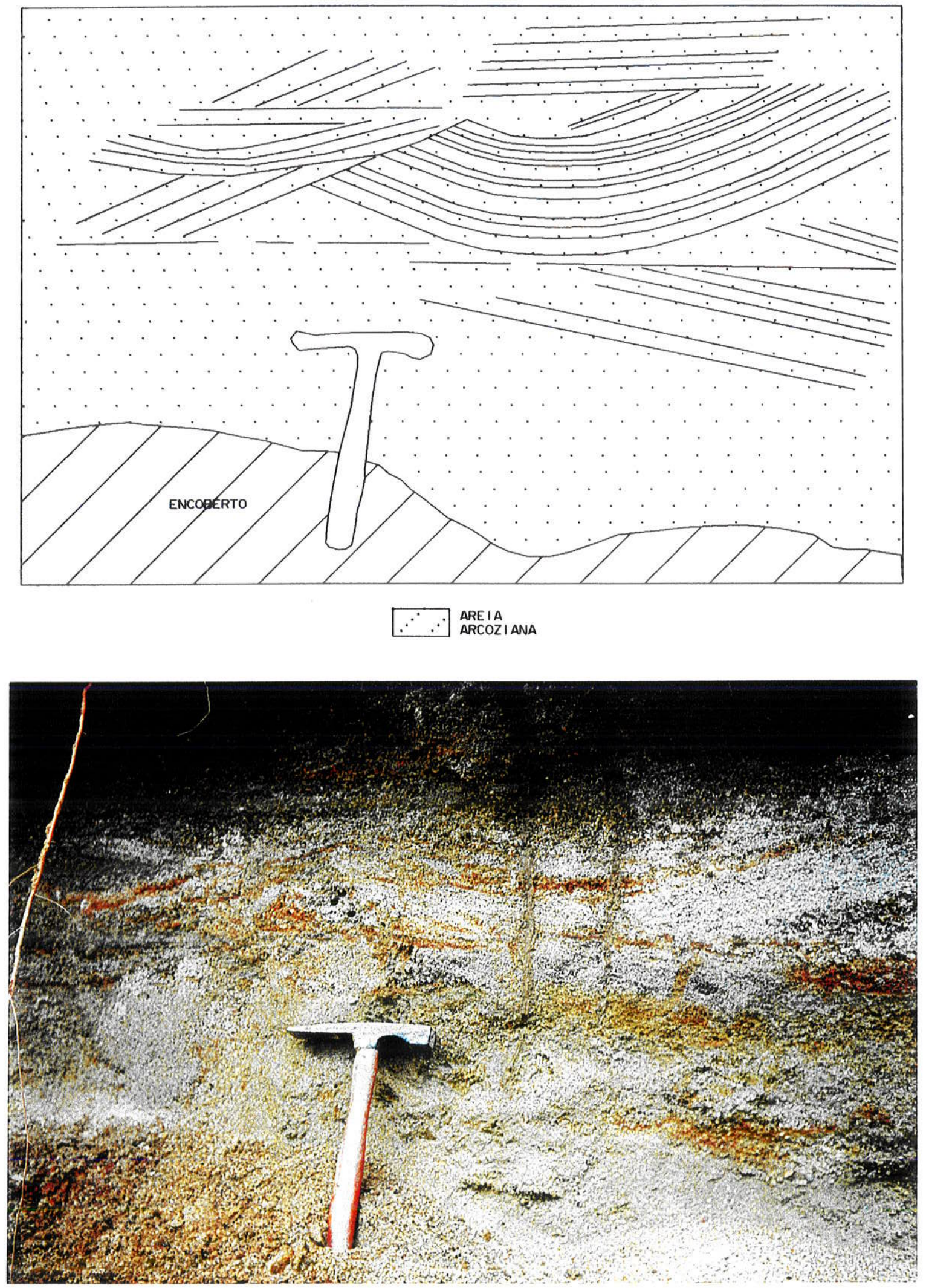

Figura 28: Depósito de areia arcoziana do leque aluvial Colônia Pereira apresentando estrutura de escavação e e preenchimento com estratificações cruzadas e plano-paralelas (ponto 20.11.91-01). 
As lamas apresentam-se em camadas de $0,20 \mathrm{~m}$ a $0,40 \mathrm{~m}$ que geralmente intercalam-se com camadas de areia arcoziana. A textura predominante é sílticaarenosa, conforme a classificação de Shepard (1954) - (ANEXO 1).

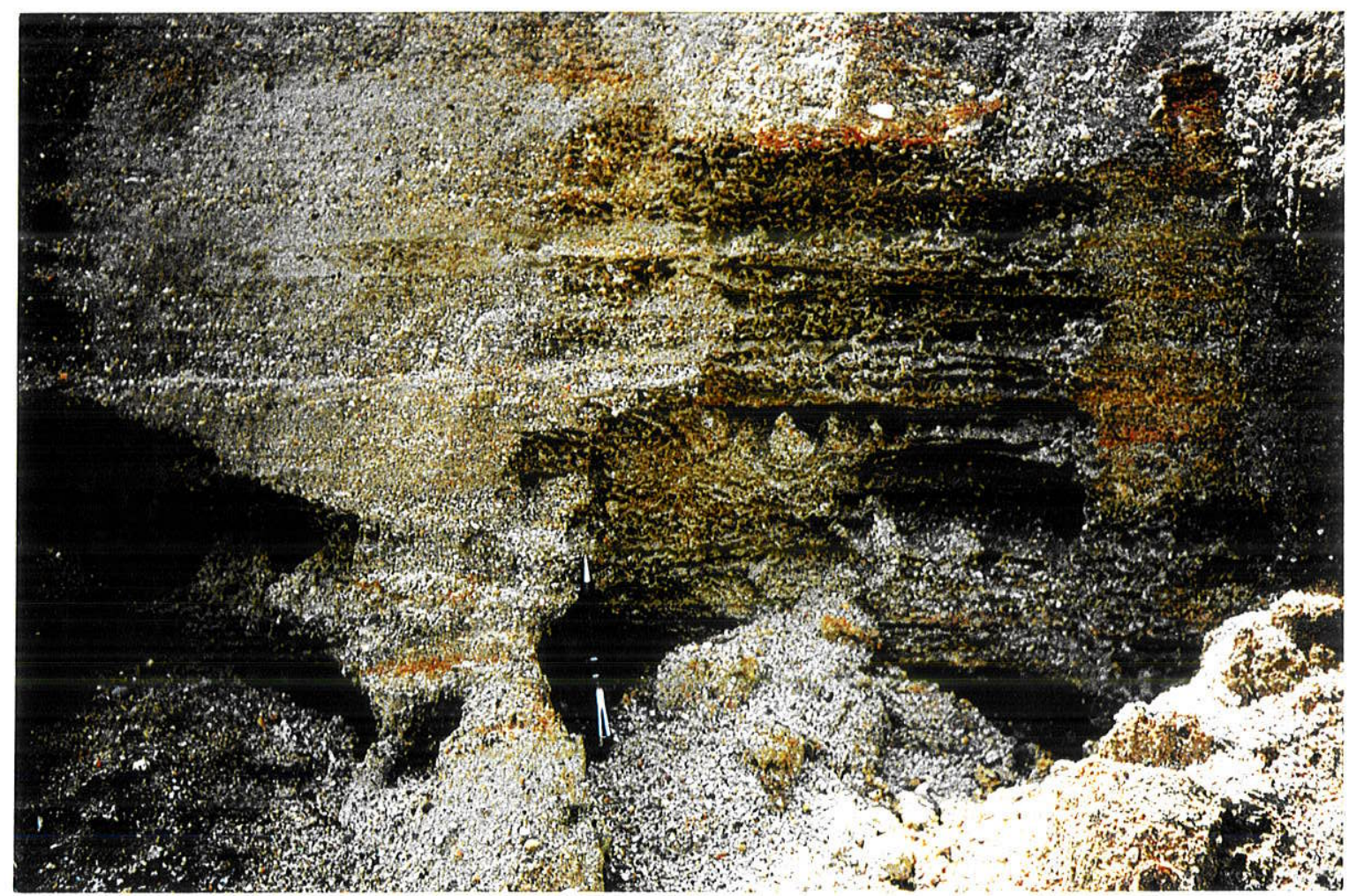

Figura 29: Depósito de areia arcoziana do leque aluvial Colônia Pereira apresentando estratificações plano-paralelas sub-horizontais (ponto 20.11.91-01).

Ocorrem grânulos de quartzo subarredondados e raros feldspatos moderadamente selecionados, com presença muito comum de micas. Internamente as lamas não apresentam estruturas visíveis e no topo de suas camadas podem ser encontrados antigos canais que foram escavados e preenchidos por sedimentos de areia arcoziana da camada sobreposta (Fig. 31).

Os cascalhos sustentados por matriz foram encontrados em camadas de até $1,60 \mathrm{~m}$ de espessura. A matriz assemelha-se muito às lamas, sendo composta de argila cinza e fração de areia grossa, com grãos de quartzo, feldspatos e fragmentos líticos de granitos, normalmente subangulares e mal selecionados. 


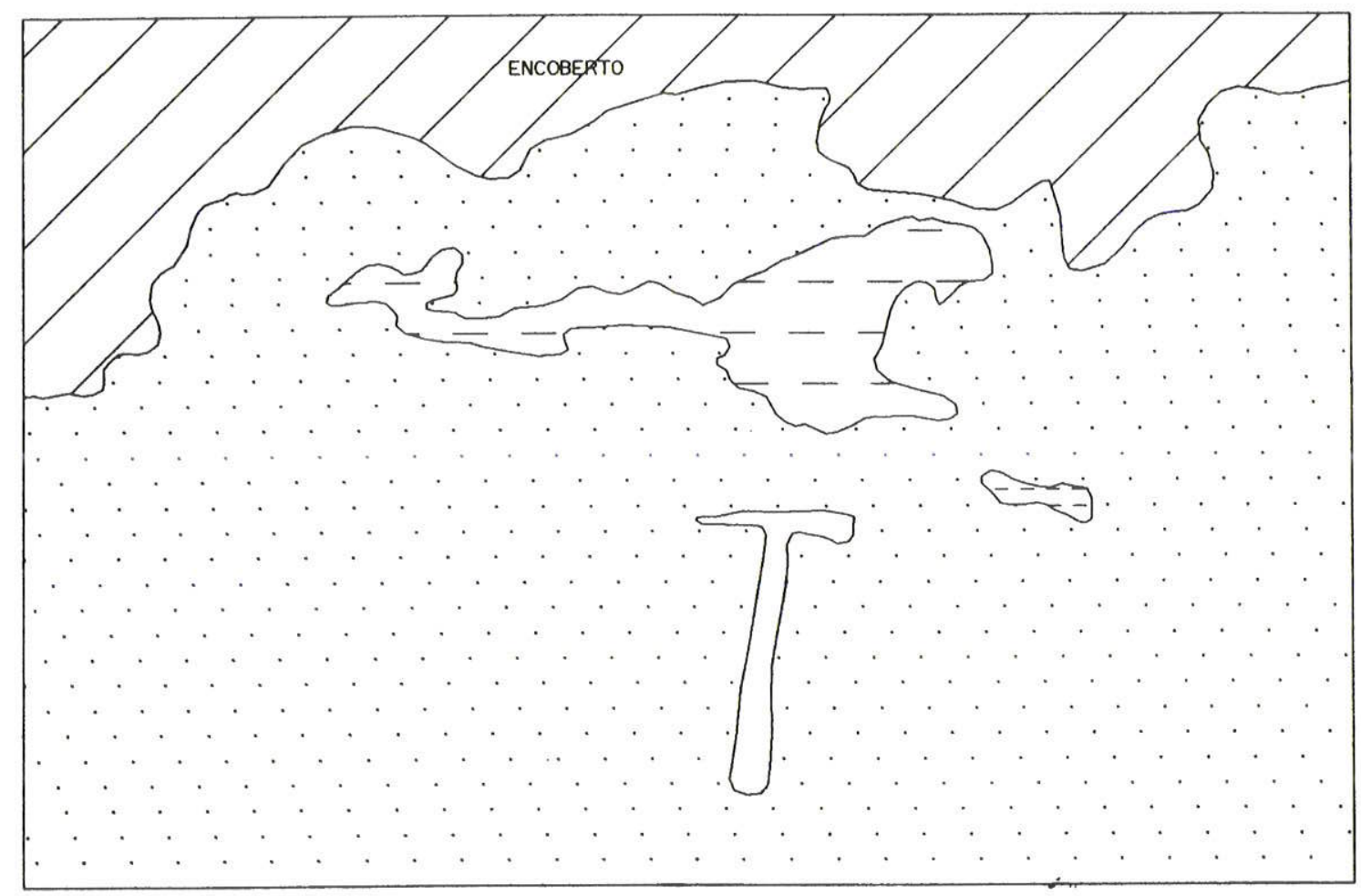

$\because \because$ AREIAIIANA

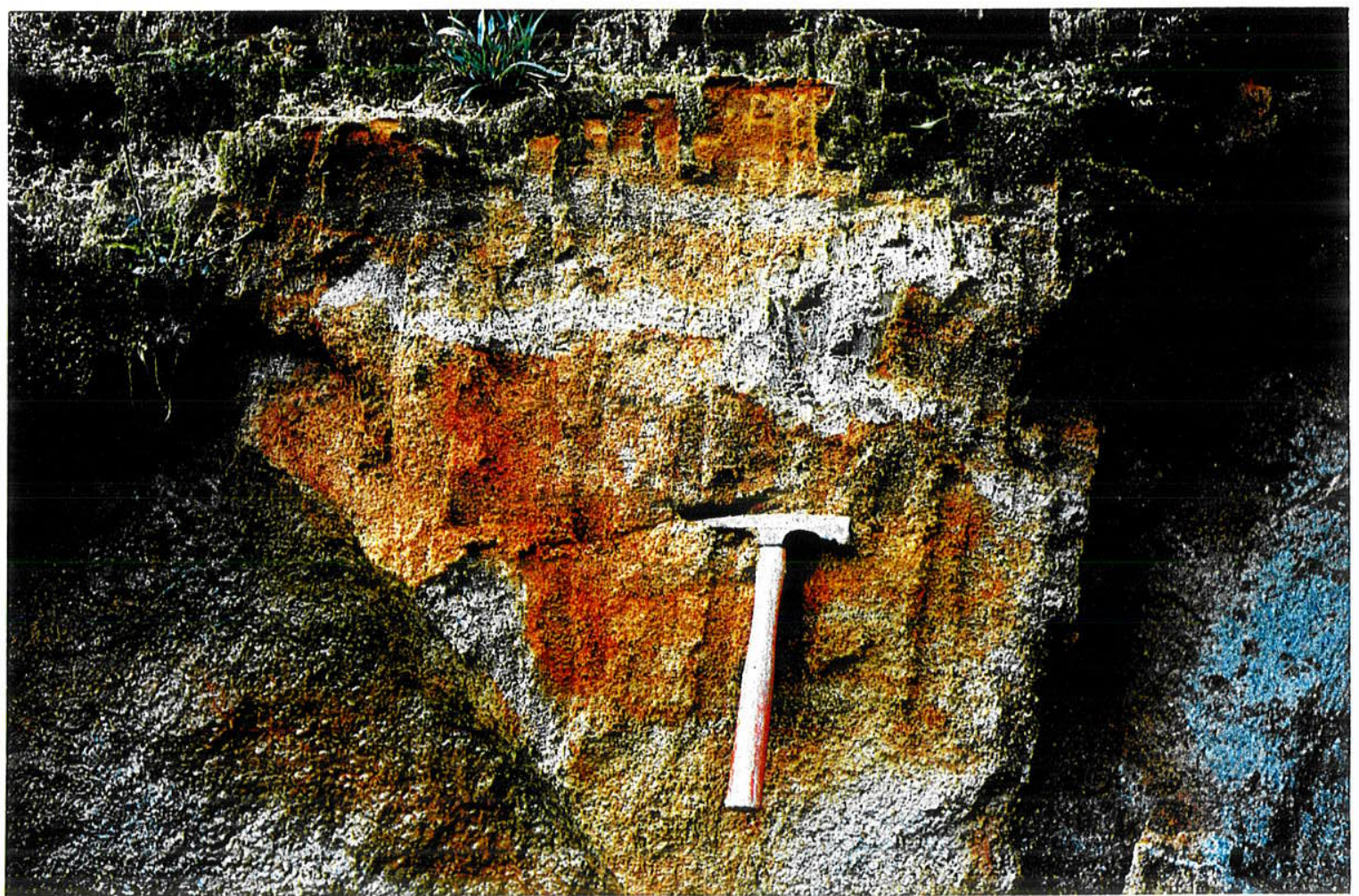

Figura 30: Bloco de lama deformada no meio de areia arcoziana do leque aluvial Colônia Pereira (ponto 20.11.91-01) 


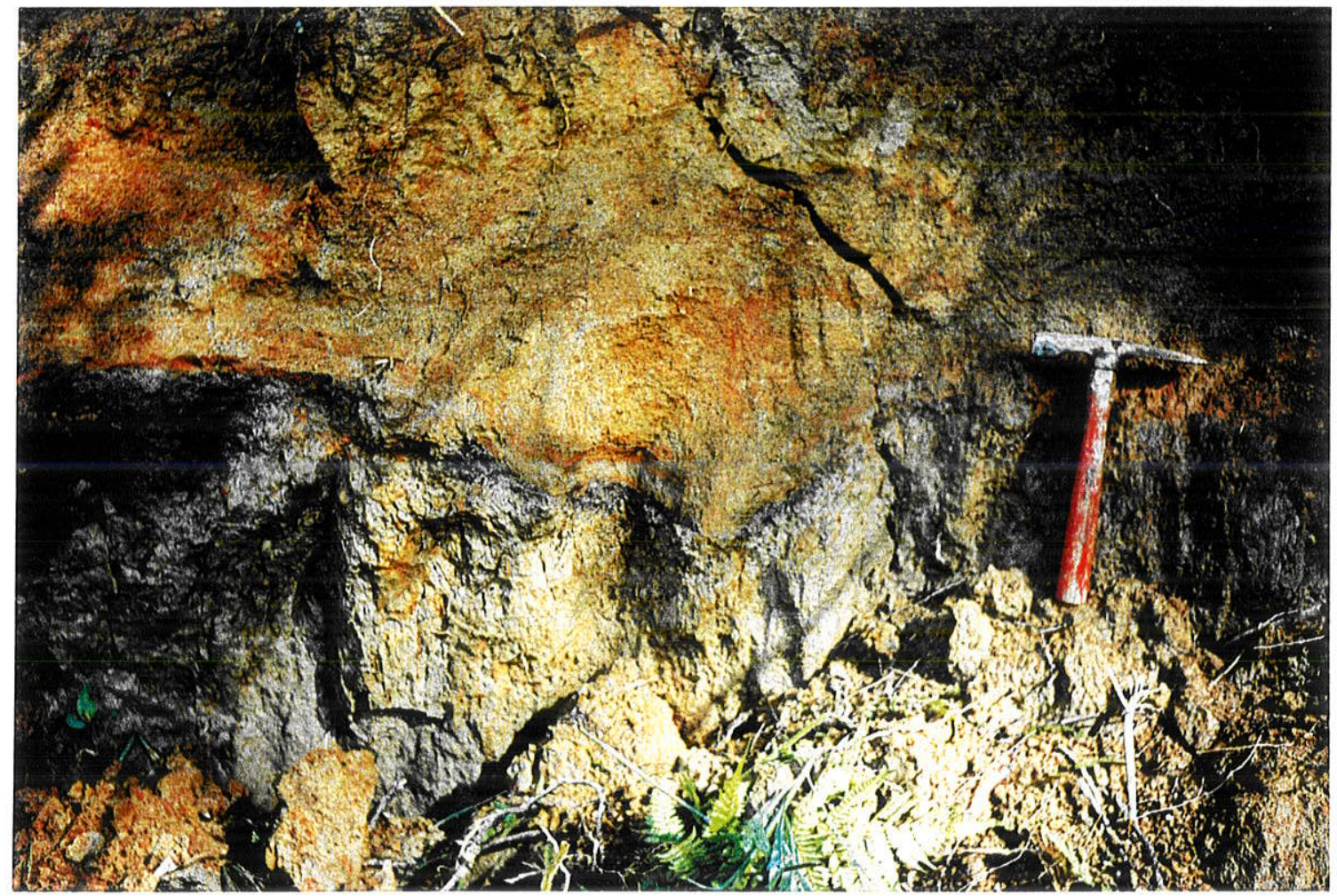

Figura 31: Depósito de lama do leque aluvial Colônia Pereira apresentando paleocanal preenchido com areia arcoziana (ponto 20.11.91-02).

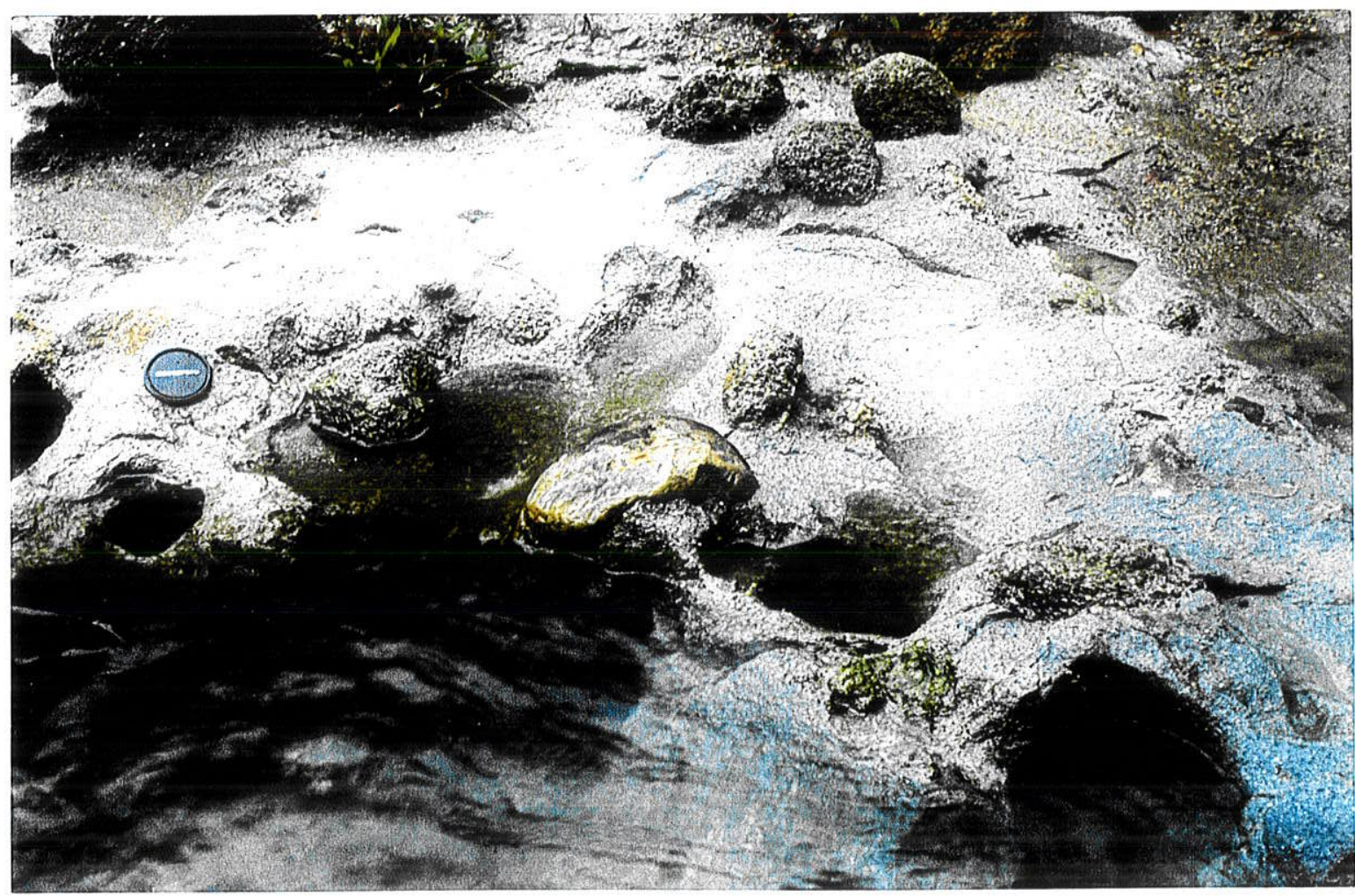

Figura 32: Depósito de cascalho sustentado por matriz do leque aluvial Colônia Pereira (ponto 20.11.91-01). 
Os clastos estão dispostos aleatoriamente na matriz, com tamanhos que variam de seixos a matacões (Fig. 32), sendo compostos principalmente de granitos e subsidiariamente de quartzo. Os clastos de granito encontram-se bem arredondados e os de quartzo subarredondados. Internamente parecem apresentar estrutura maciça.

Cascalhos sustentados por clastos foram encontrados_em apenas dois afloramentos e possuem as mesmas características sedimentológicas das areias arcozianas, diferenciando-se destas apenas por possuir maior quantidades de seixos (acima de 5\%). Os depósitos destes cascalhos tem espessuras de $0,70 \mathrm{~m}$ e $0,72 \mathrm{~m}$, e são formados por matriz areno-argilosa de cor marrom, composta de grãos de quartzo e feldspato subarredondados. Os clastos têm tamanhos de grânulos a seixos subarredondados, compostos de quartzo, feldspatos e fragmentos líticos de granitos. Os depósitos desses conglomerados apresentaram estruturas de granocrescência ascendente dos clastos (Fig. 33). Na base dessas camadas, constatou-se a presença de paleocanais.

A areia fina apresenta intercalações de lentes arenosas e síltico-argilosas bem selecionadas, com espessura das camadas entre $0,14 \mathrm{~m} \mathrm{e} \mathrm{0,44} \mathrm{m}$. A espessura das lentes varia de 1 a $2 \mathrm{~mm}$. Localmente foram encontrados grânulos de quartzo subarredondados. As lentes mostram estratificações plano-paralelas e cruzadas de baixo ângulo e acham-se intercaladas com camadas de silte arenoso de cor preta com muitas micas, com espessura de até $0,65 \mathrm{~m}$, apresentando estratificações planoparalelas e contendo restos de troncos, caules e folhas (Fig. 34).

Os finos foram encontrados somente em um afloramento (ponto 20.11.9101D), em camada de $0,17 \mathrm{~m}$ de espessura. Trata-se de silte de cor cinza e vermelha, com muitas micas e laminações plano-paralelas.

Os depósitos mais característicos do leque aluvial Colônia Pereira são apresentados nas Figs. 35 e 36. 


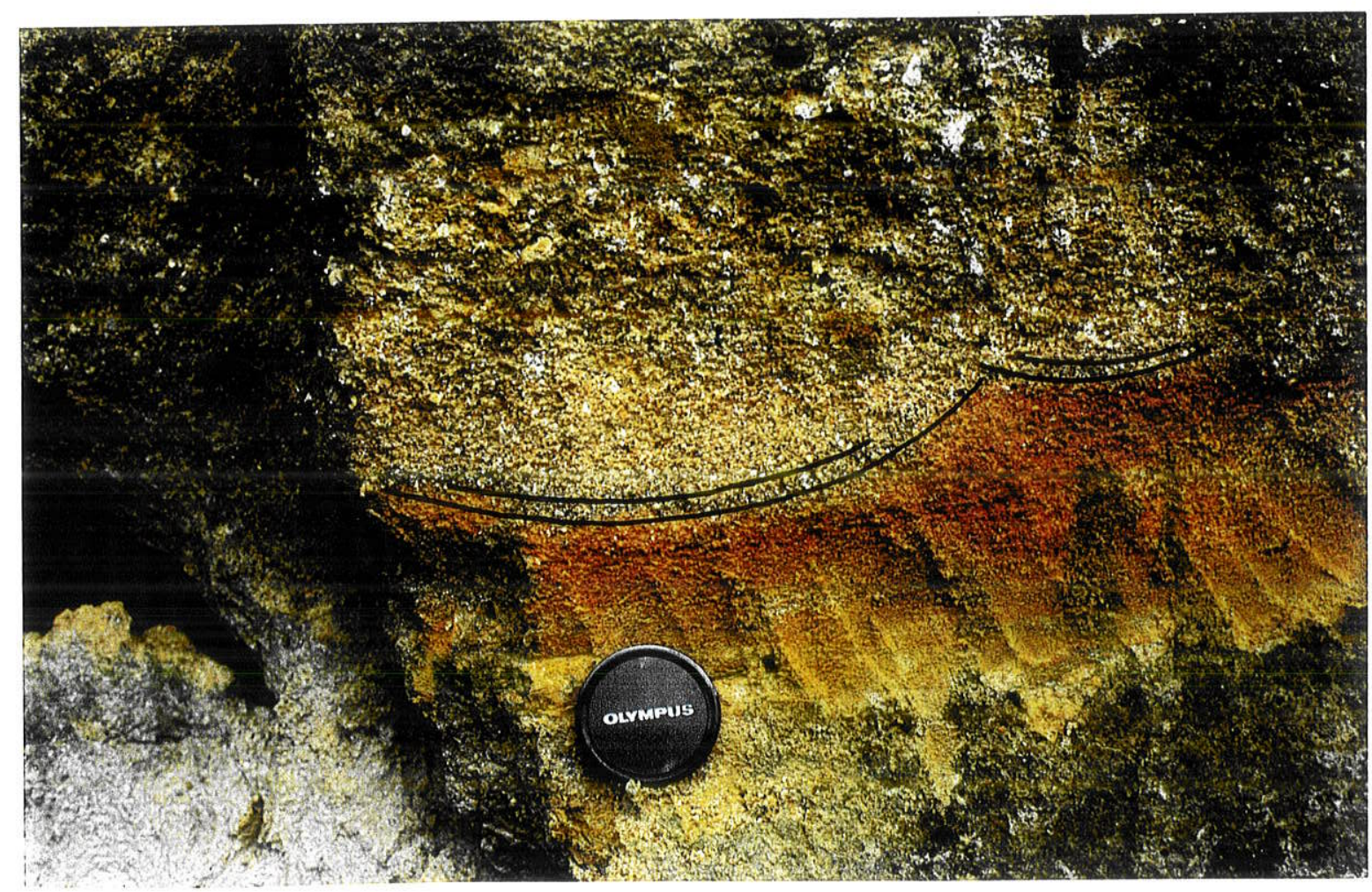

Figura 33: Depósito de cascalho sustentado por clastos do leque aluvial Colônia Pereira com estruturas de escavação e preenchimento e granocrescência ascendente (ponto 20.11.91-01).

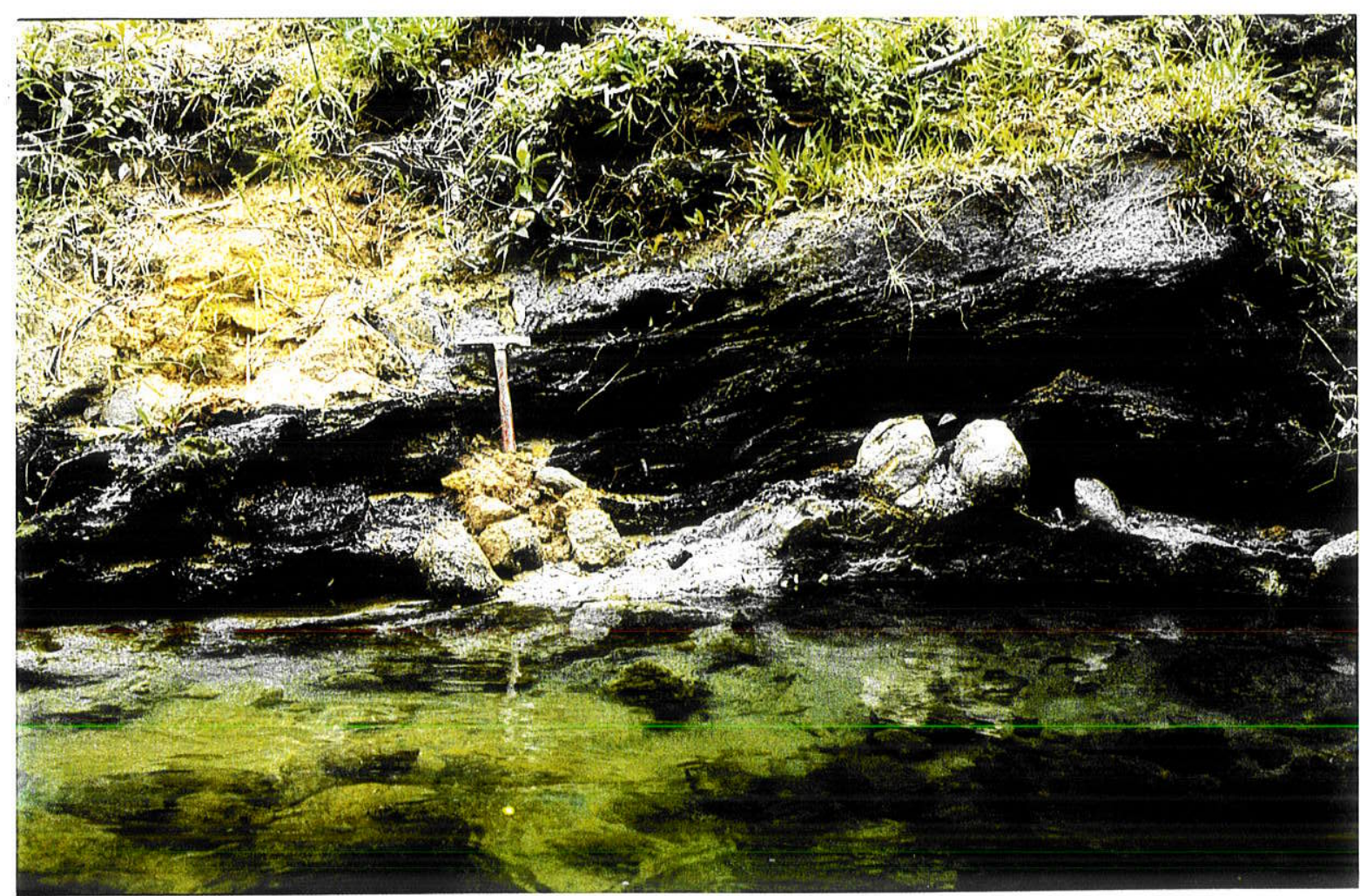

Figura 34: Depósito de silte arenoso contendo vegetais fósseis do leque aluvial Colônia Pereira (ponto 20.11.91-01). 

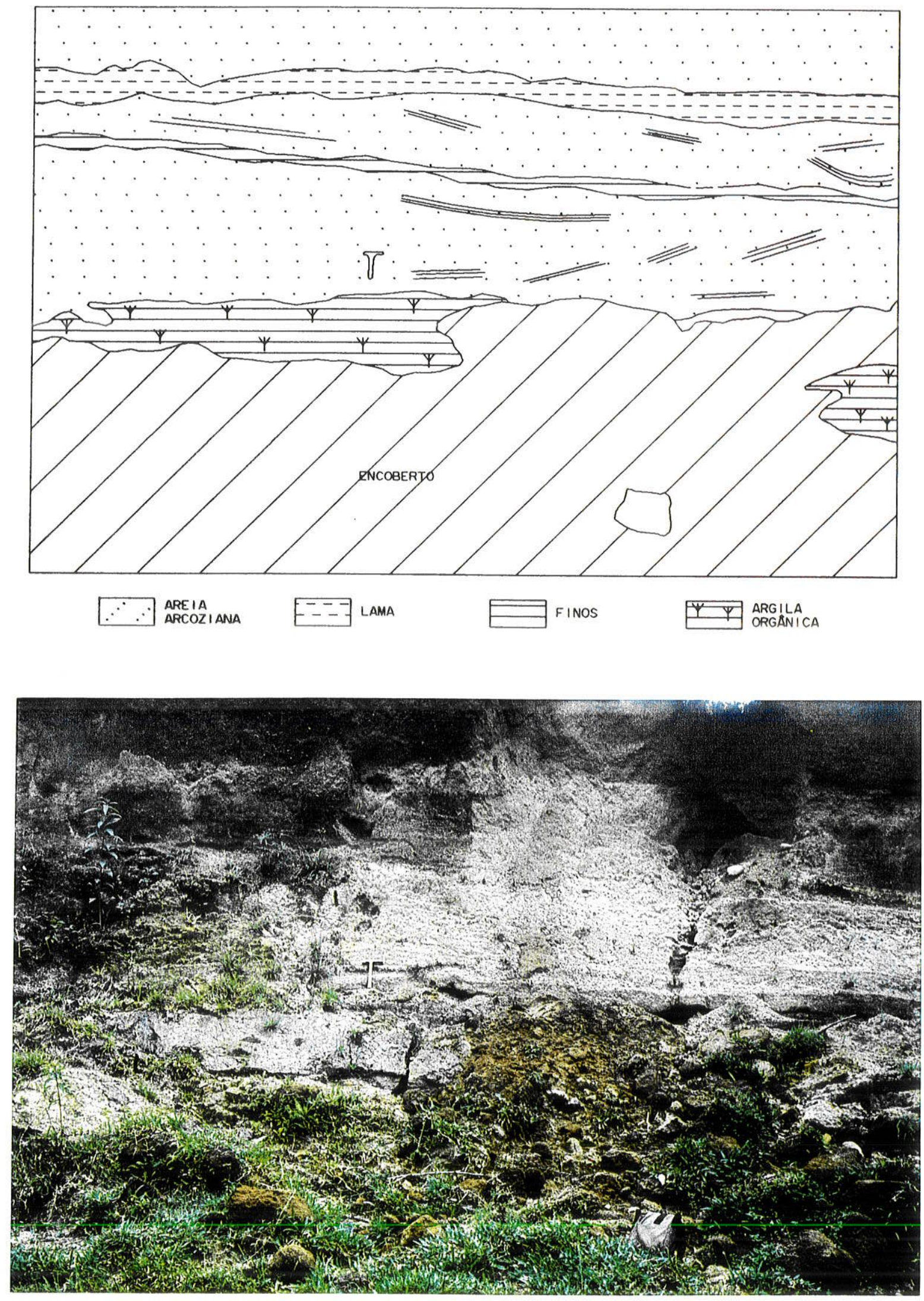

Figura 35: Afloramento característico do leque aluvial Colônia Pereira (ponto 20.11.9101) 


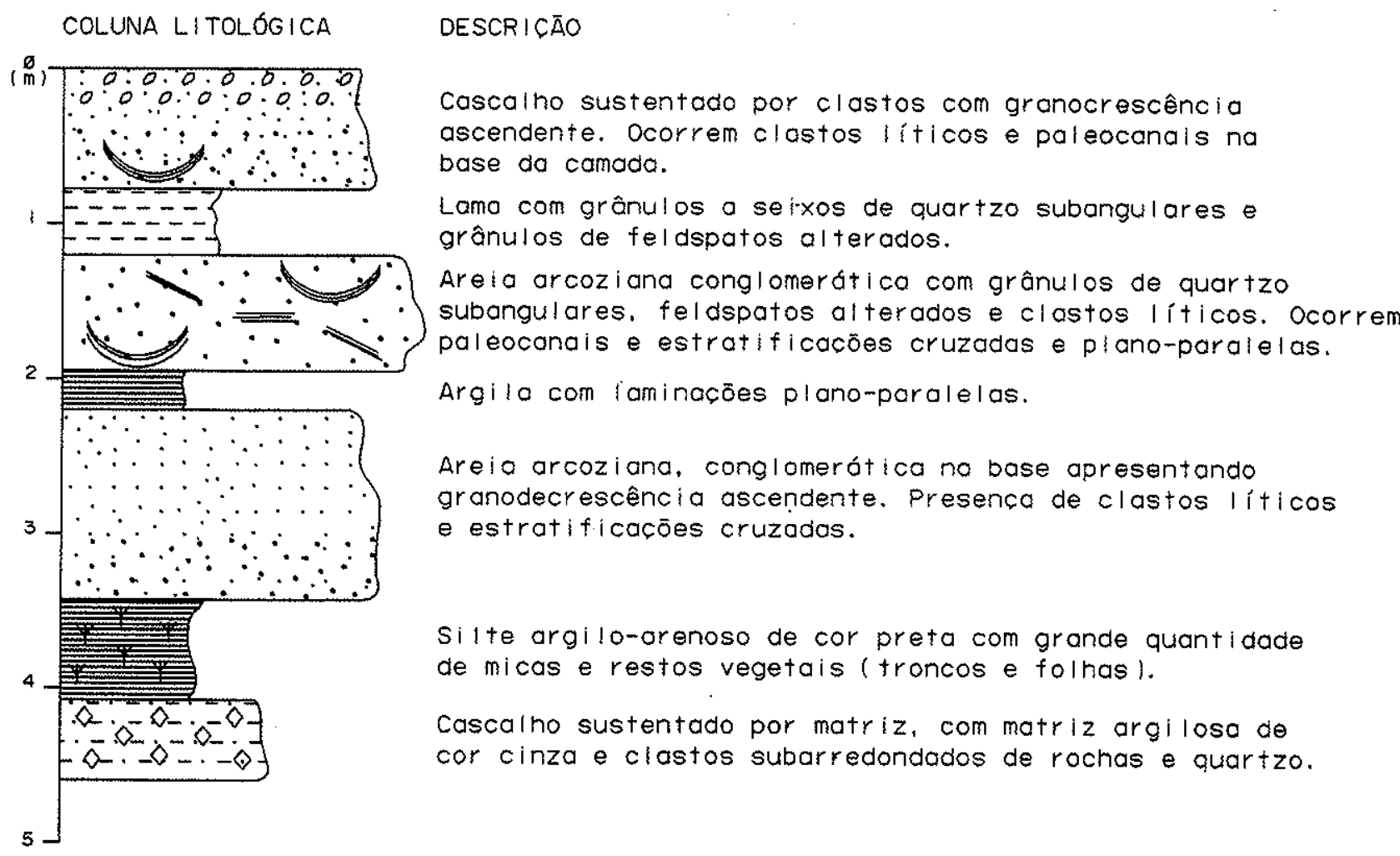

Figura 36: Esquema dos depósitos sedimentares do leque aluvial Colônia Pereira (ponto 20.11.91-01).

\section{Leque Aluvial Cambará/Cachoeirinha (Qcc)}

Devido à coalescência verificada em fotointerpretação para estes dois leques, eles serão apresentados em uma única descrição. Os sedimentos que compõem estes leques aluviais são areia arcoziana, areia fina, lama e areia grossa em proporções semelhantes, e subsidiariamente cascalho sustentado por matriz.

As areias arcozianas ocorrem em camadas de 0,25 a $1,65 \mathrm{~m}$ de espessura, com cores cinza e marrom e possuem uma granulometria fina a grossa, com grânulos de quartzo, feldspatos e fragmentos líticos subarredondados de granitos. Os feldspatos e os fragmentos líticos apresentam-se bastante alterados. Também foram encontrados minerais pesados em proporções superiores a $5 \%$. Em geral, as características texturais dessas areias são similares às encontradas no leque aluvial Colônia Pereira. 
Em alguns depósitos de areias arcozianas do leque aluvial Cambará/Cachoeirinha ocorre granocrescência ascendente (Fig. 37), passando de areia fina na base para areia grossa a cascalhosa no topo.

Ocorrem pelotas de argila em meio à camada de areia, na forma de seixos e matacões bem arredondados (Fig. 38).

As areias grossas possuem possuem grãos bem selecionados e arredondados, com características sedimentológicas e texturais semelhantes às areias arcozianas, entretanto, contém poucos grãos de feldspatos e/ou fragmentos líticos $(<15 \%)$. Comumente apresentam granocrescência ascendente e ocorrem em depósitos de 0,30 a 0,65 $\mathrm{m}$ de espessura, intercalando-se com depósitos de areia fina, onde apresentam contatos abruptos. Localmente foram encontradas lentes argilosas, com 1 a $2 \mathrm{~mm}$ de espessura no meio de depósito de areia.

As areias finas possuem grãos bem arredondados e bem selecionados, ocorrendo em camadas de 0,20 a $0,55 \mathrm{~m}$. Em alguns depósitos ocorre granodecrescência ascendente, sendo que localmente pode ocorrer maior quantidade de argila na base das camadas que no topo.

Os depósitos compostos de areias foram encontrados nas porções mais distais deste leque aluvial, em áreas de relevo plano, provavelmente correspondente à planície aluvial dos rios Cambará e Cachoeirinha.

As lamas ocorrem em camadas de cerca de $0,50 \mathrm{~m}$ de espessura, sendo compostas de argila cinza, localmente castanha, bastante plástica e sem estruturas visíveis. Os clastos ocorrem dispersos na argila, sem nenhuma seleção e normalmente apresentam tamanhos de grânulos, podendo raramente ser encontrados alguns seixos. São compostos de quartzo e feldspatos, subangulares a subarredondados, com os feldspatos bastante alterados. Visualmente estes lamas são muito semelhantes as que foram encontradas no leque aluvial Colônia Pereira. Na camada de lama encontrada no leito do rio Cambará, ocorrem fragmentos de troncos, caules e folhas, que foram datadas pelo método do ${ }^{14} \mathrm{C}$. 


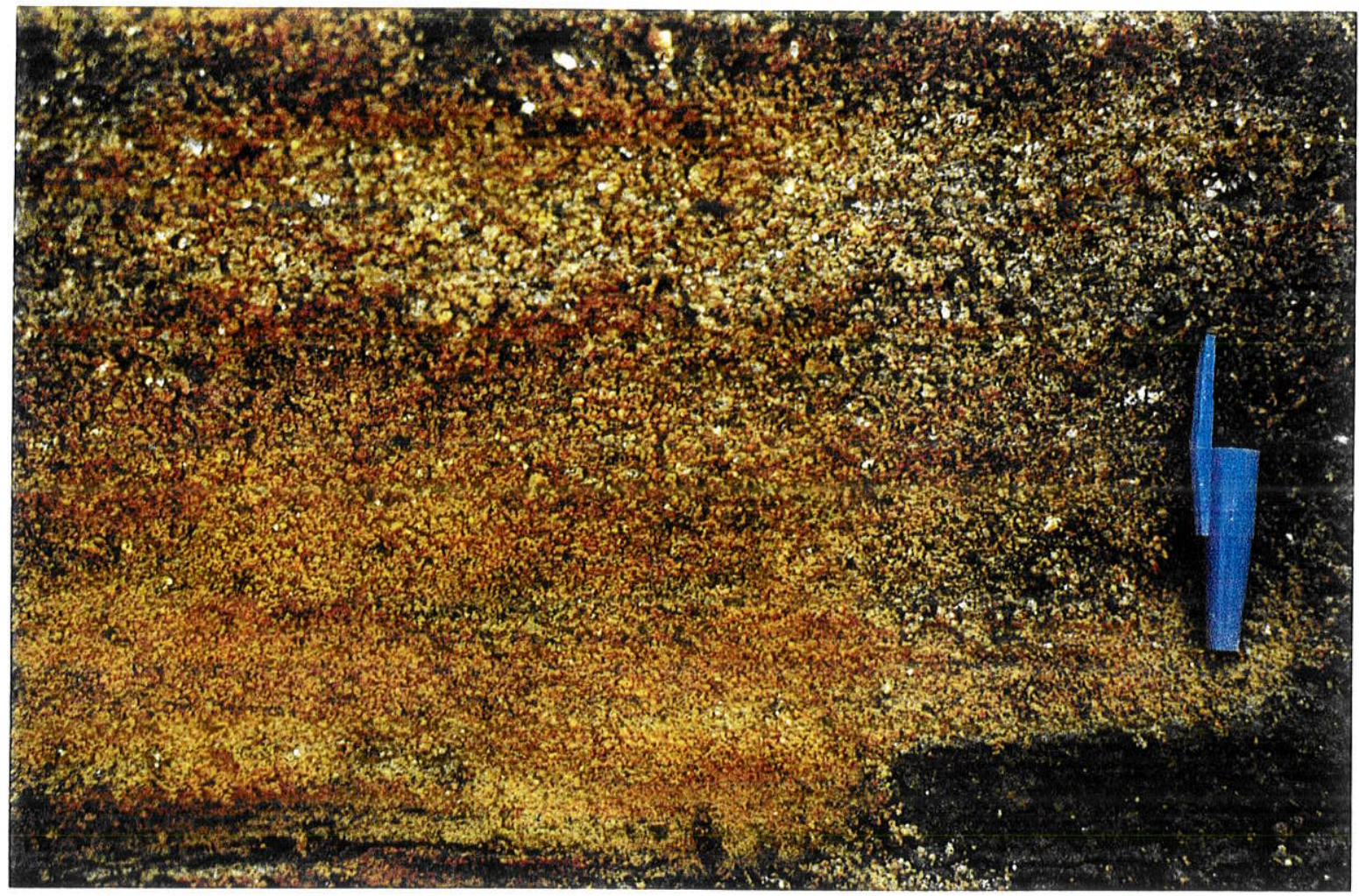

Figura 37: Detalhe da granocrescência ascendente em areia arcoziana do leque aluvial Cambará/Cachoeirinha (ponto 23.1.91-02).

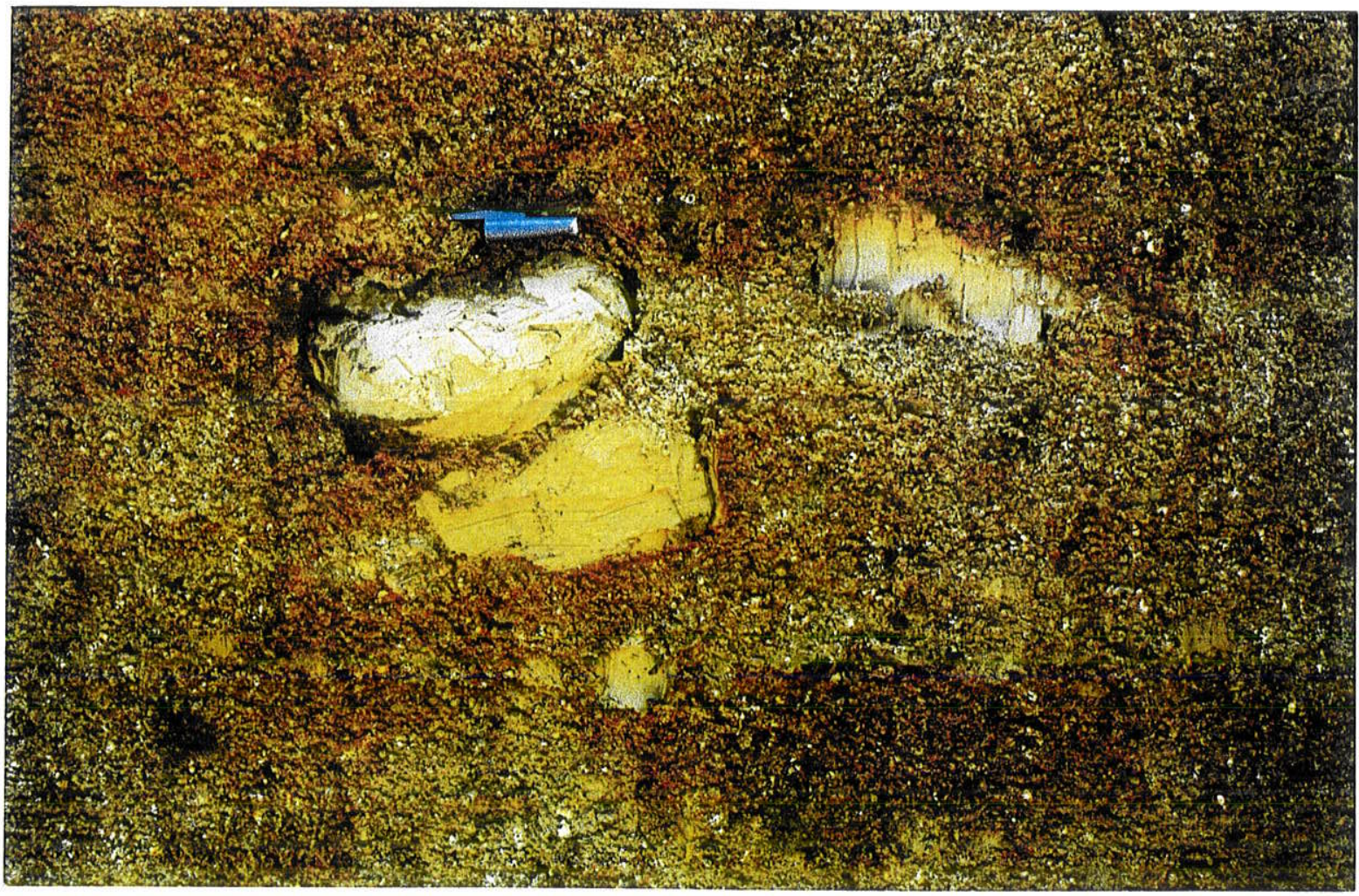

Figura 38: Detalhe de pelotas de argila em areia arcoziana do leque aluvial Cambará /Cachoeirinha (ponto 23.1.92-01). 
Depósitos de cascalhos sustentados por matriz puderam ser encontrados em áreas mais proximais dos leques (Fig. 39). Apresentam matriz areno-argilosa, com fração de areia grossa mal selecionada, com grânulos subangulares de quartzo, feldspatos alterados e fragmentos líticos de granito. Os clastos são de seixos a blocos de granitos, raramente de quartzo, subarredondados, que ocorrem dispersos aleatoriamente na matriz, podendo ocasionalmente se tocarem. Internamente a matriz apresenta estrutura maciça.

Na Fig. 40 é apresentada um esquema com a seqüência das camadas sedimentares que ocorrem no afloramento do ponto 23.1.92-02, mostrando similaridade com as que foram encontradas no leque aluvial Colônia Pereira.

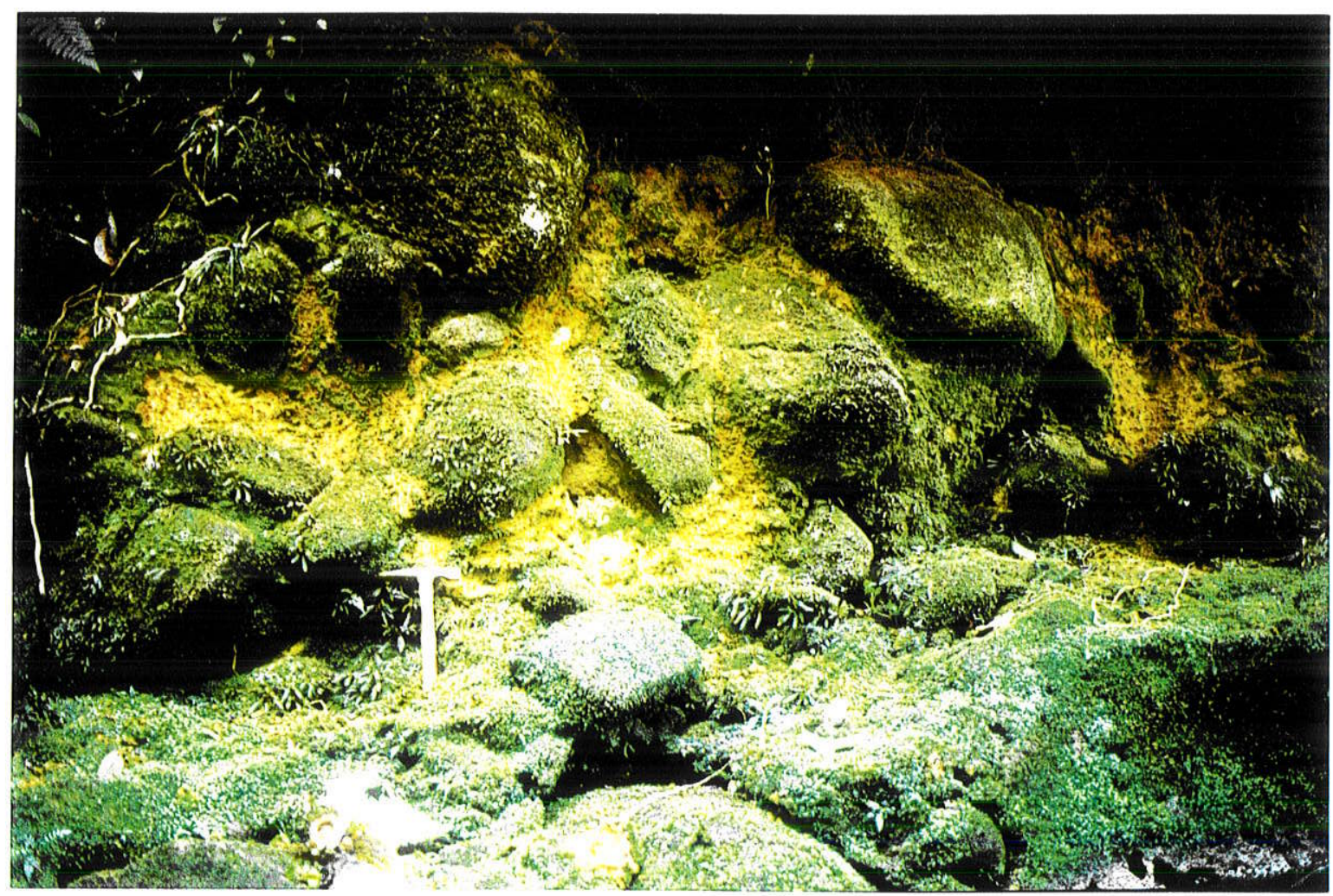

Figura 39: Depósitos de cascalhos sustentados por matriz do leque aluvial Cambará/Cachoeirinha (ponto 06.2.92-03). 

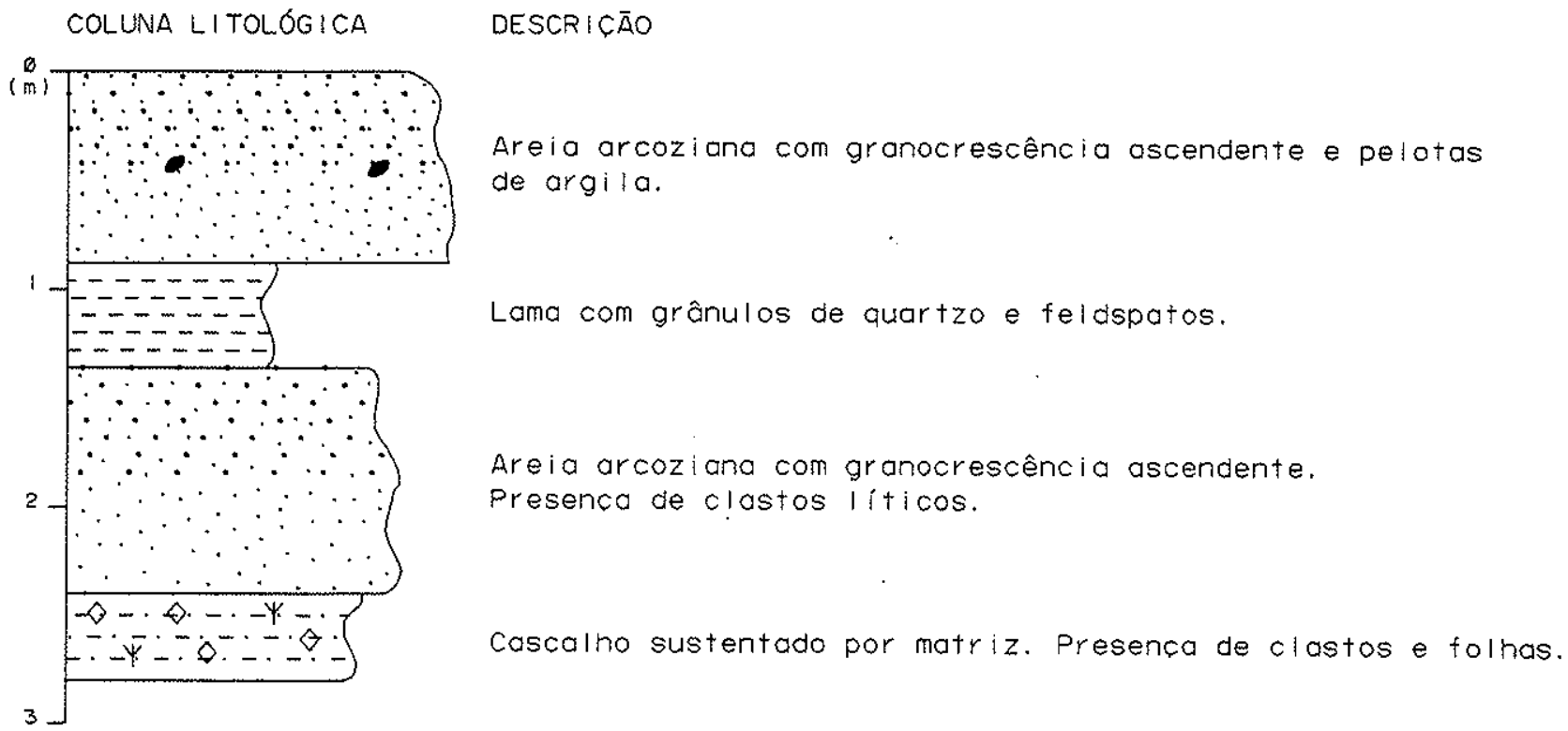

Figura 40: Esquema apresentando as camadas sedimentares do leque aluvial Cambará/Cachoeirinha (ponto 23.1.92-02).

\section{Leque Aluvial Cubatão $(\mathrm{Oc})$}

Neste leque aluvial predominam os sedimentos arenosos (ANEXO 1), como as areias finas, arcozianas e grossas e, raramente apresenta finos.

Entre as areias, predominam camadas de areia fina, que ocorrem com espessuras 0,25 a $0,68 \mathrm{~m}$. Possuem grãos bem selecionados e arredondados de quartzo, micas e minerais pesados, tendo em alguns depósitos grande quantidade de finos (ANEXO 1) em meio à areia. Localmente apresentam granodecrescência ascendente são moderadamente selecionadas.

As areias arcozianas e areias grossas possuem características sedimentológicas similares, diferenciando-se na quantidade de grãos de feldspatos presentes (superior a $15 \%$ para as areias arcozianas). Além destes, ocorrem grãos subarredondados de quartzo, micas e minerais pesados. São pobremente a muito pobremente selecionadas, podendo localmente chegar a cascalhosas. Além da 
granodecrescência ascendente, apresentam incipientes estratificações plano-paralelas, cruzadas e estruturas de escavação e preenchimento (Fig. 41).

Apenas em um afloramento (ponto 10.3.92-03) foi observada a ocorrência de argila plástica de cor castanha clara, com presença de estruturas de tubos preenchidos pela própria argila.

\section{Leque Aluvial Morretes (Qm)}

Através dos trabalhos de fotointerpretação observou-se que o leque aluvial Morretes possue lineamentos geomórficos muito bem definidos. No entanto, poucos e bons afloramentos foram encontrados em campo, dificultando a realização de descrições e análises sedimentológicas para esta unidade.

No leque aluvial Morretes predominam cascalhos sustentados por clastos, ocorrendo subsidiariamente lamas, finos e cascalho sustentado por matriz.

O cascalho sustentado por clastos é polimítico e ocorre em camadas de até $0,78 \mathrm{~m}$ de espessura, sendo os clastos de quartzo, granito, gnaisse e diabásio.

São bem arredondados, com tamanhos de seixos a matacões que apresentam imbricações e incipientes estratificações cruzadas de baixo ângulo (Fig. 42). A matriz areno-argilosa tem cor cinza clara, sendo que a fração arenosa grossa é mal selecionada, com grânulos de quartzo e fragmentos líticos de granitos subangulares e feldspatos alterados. Localmente, a matriz pode conter maior quantidade de argila, passando a verdadeiras lamas. Em afloramento do rio Marumbi (ponto 21.2.91-01), constatou-se a presença de paleocanal na base do cascalho sustentado por clastos, em contato com camada de finos que se encontra sotoposta (Fig. 43).

As lamas foram encontradas em camadas de $0,32 \mathrm{~m}$ de espessura, sendo compostas de argila arenosa de cor cinza, com grânulos a seixos subangulares de quartzo, feldspatos e fragmentos líticos de granito. A fração arenosa das lamas é muito pobremente selecionada e apresenta granodecrescência ascendente. 

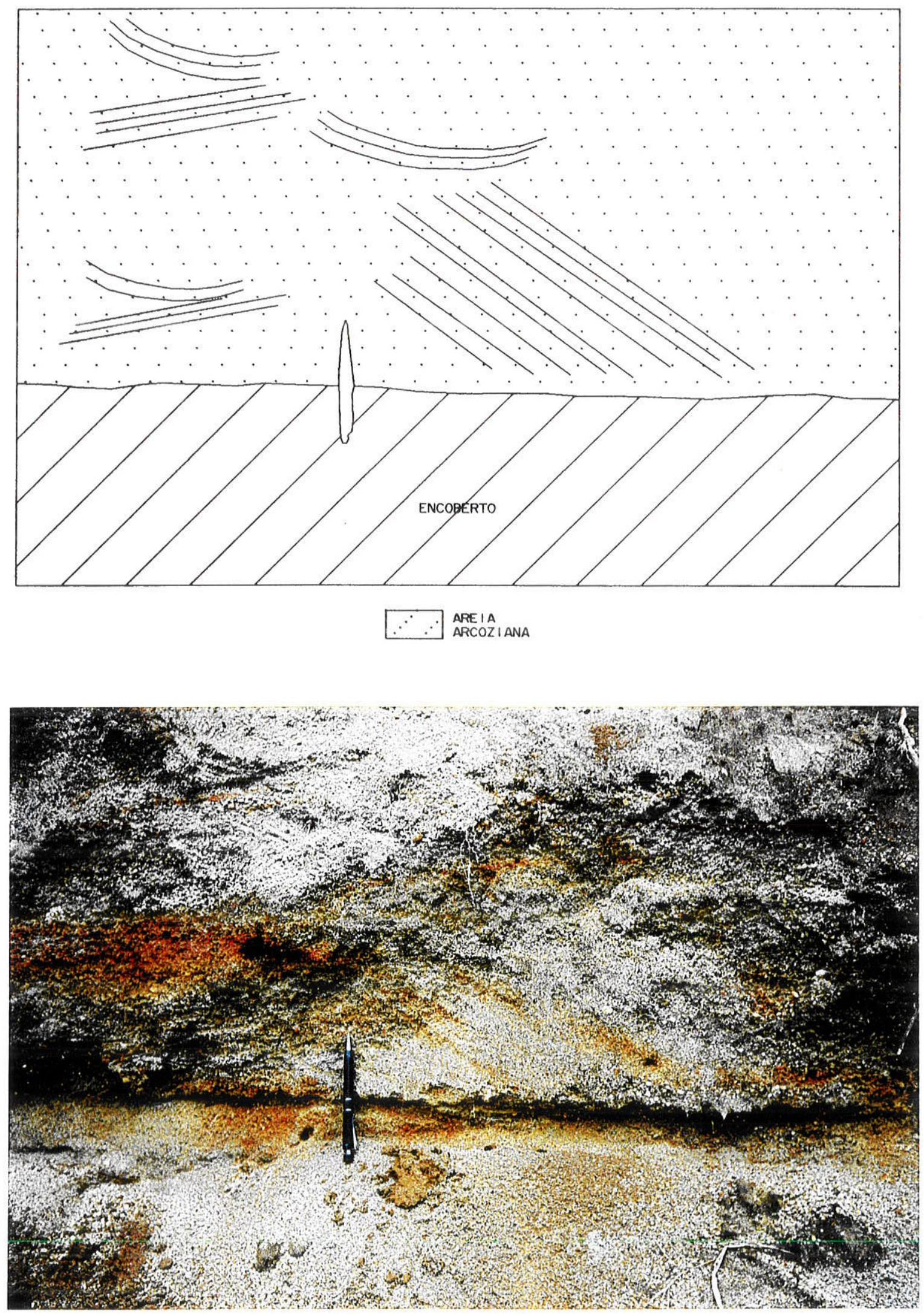

Figura 41: Depósito de areia arcoziana do leque aluvial Cubatão, apresentando estratificações cruzadas e estruturas de escavação e preenchimento. Afloramento situado à margem do rio Cubatão (ponto 10.3.92-03). 


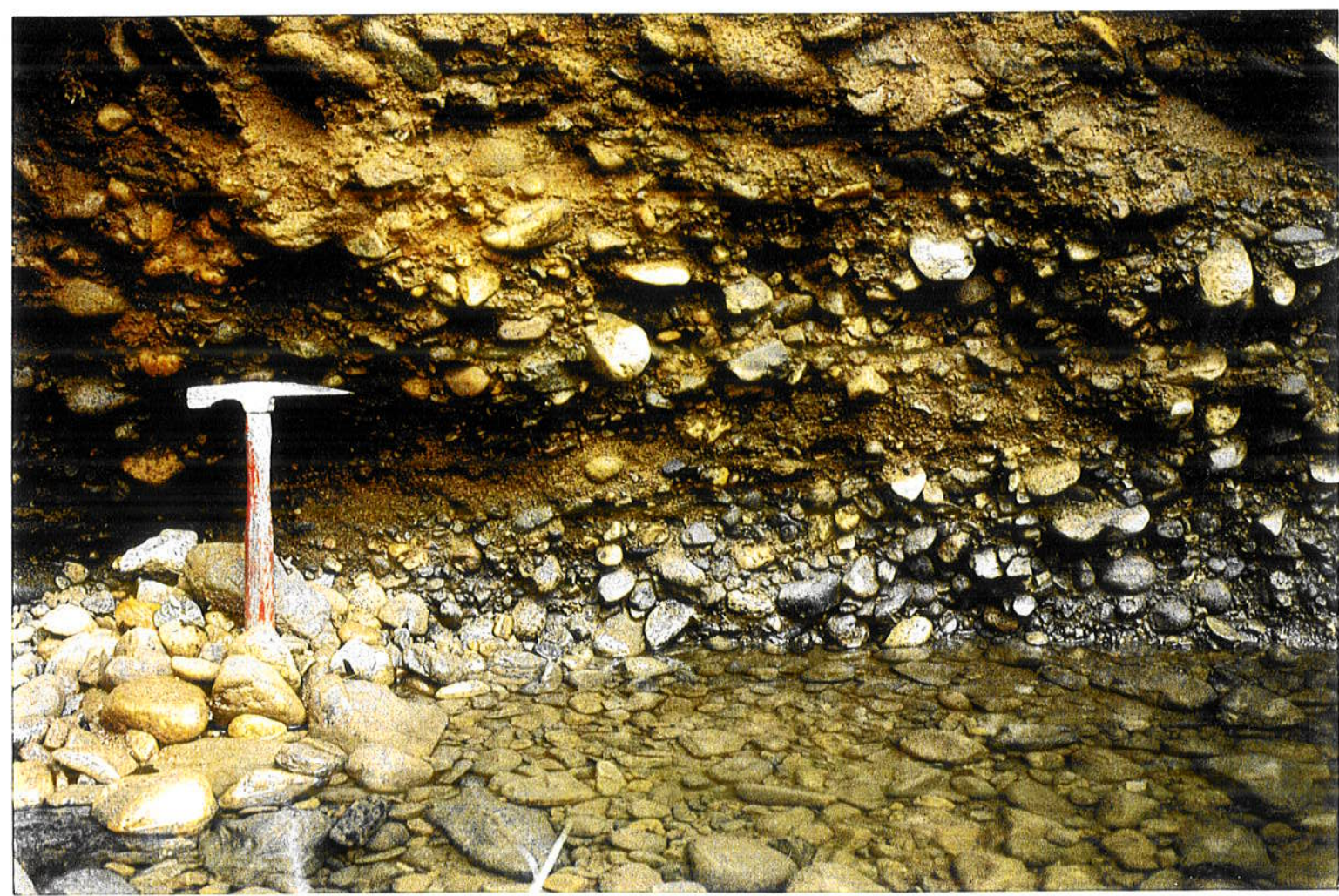

Figura 42: Depósito de cascalho sustentado por clastos do leque aluvial Morretes, apresentando imbricações de seixos e estratificações cruzadas. Afloramento situado à margem do rio Nhundiaquara (ponto 11.2.92-01).

Os finos ocorrem apenas em uma camada no ponto 21.2.92-01 (Fig. 43), com cerca de $0,25 \mathrm{~m}$ de espessura e são compostos por argila síltica orgânica de cor cinza escura, com presença de troncos de árvores e folhas. É no topo desta camada que ocorre o paleocanal já descrito para os cascalhos sustentados por clastos.

Os cascalhos sustentados por matriz estão localizados em áreas mais proximais do leque, sendo compostos por seixos a matacões de granito subarredondados que estão imersos aleatoriamente na matriz, composta de argila arenosa de cor marrom, tendo na fração arenosa grânulos subangulares de quartzo, feldspatos bastante alterados e fragmentos líticos de granito. Aparentemente a matriz apresenta estrutura maciça. Possuem muita semelhança com os cascalhos sustentados por matriz que foram descritos para o leque aluvial Cambará/Cachoeirinha. 

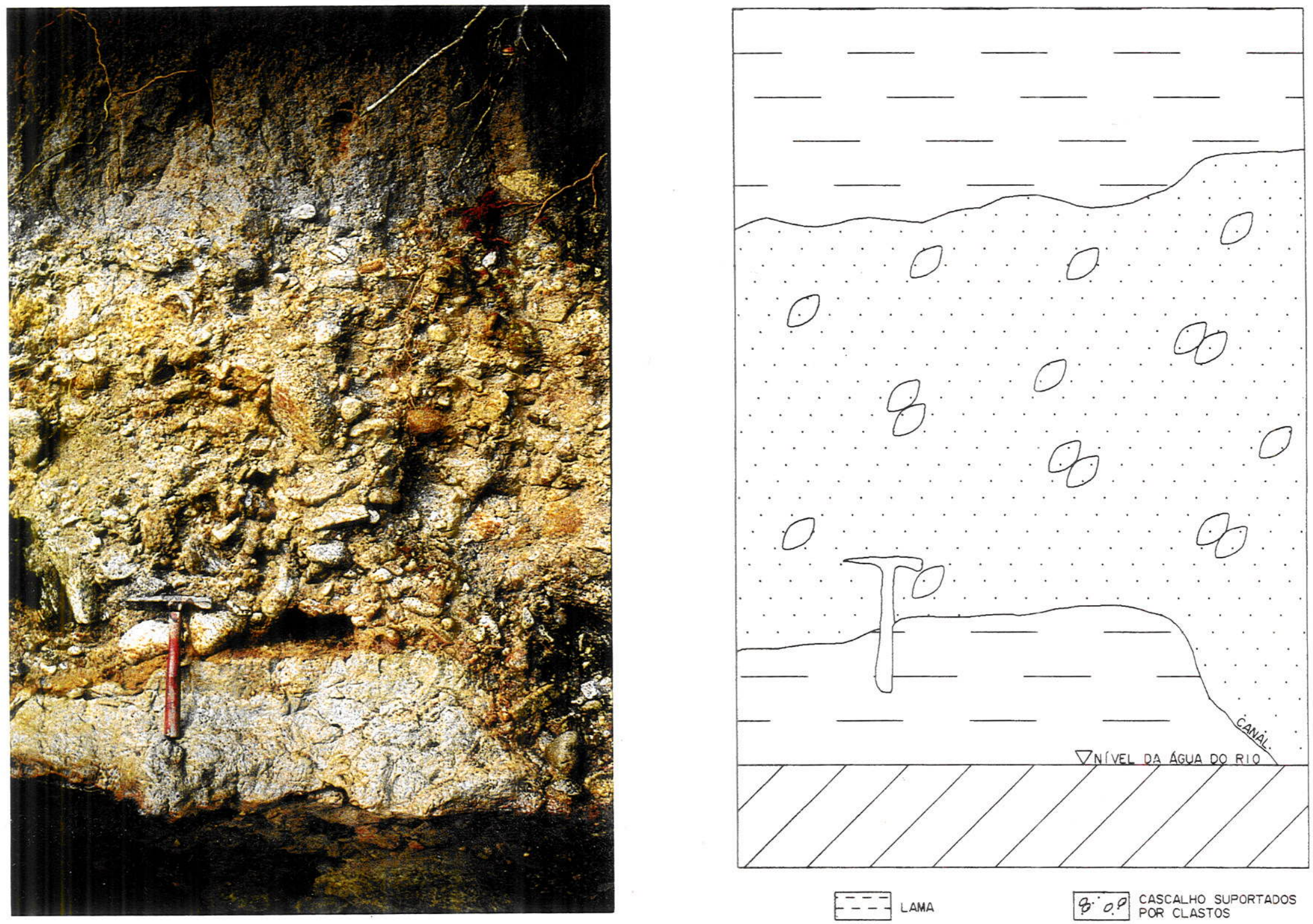

Figura 43: Sedimentos do leque aluvial Morretes, apresentando paleocanal na base do conglomerado. Afloramento situado à margem do rio Marumbi (ponto 21.2.92-01) 


\section{Leques Aluviais Brejatuba (Qb), Pombas ( $Q p)$, Caovi (Qcao), Miranda (Qm)}

Nessas unidades predominam depósitos de cascalho sustentado por matriz e lama e subsidiariamente tem-se a presença de areia arcoziana.

Os depósitos de cascalho sustentado por matriz apresentam-se com espessuras que variam de 1 a $3,7 \mathrm{~m}$. Possuem uma matriz argilo-arenosa de cor castanha escura, com grânulos subangulares de quartzo, feldspatos e fragmentos líticos, também ocorrendo localmente micas e minerais pesados. Esta matriz apresenta-se com seleção muito pobre e estrutura maciça. Os clastos são de granito, com tamanhos de matacões a blocos que podem alcançar até $2 \mathrm{~m}$ de eixo maior, ocorrendo imersos aleatoriamente na matriz argilo-arenosa. Alguns clastos apresentam-se bastante alterados, podendo ser confundidos com a matriz (Fig. 44). Em alguns desses leques aluviais, os blocos de granito podem ocorrer na superficie criando uma paisagem bastante característica (Fig. 45).

As lamas são pouco freqüentes, com camadas de espessuras de 0,50 a $1 \mathrm{~m}$ e compostas de argila arenosa de cor castanha clara, bastante similar à matriz dos conglomerados já descritos. Apresentam grânulos a seixos subangulares de fragmentos líticos, quartzo e feldspatos (Fig. 46), são muito pobremente selecionados e apresentam estrutura maciça.

Os depósitos de areias arcozianas são encontrados em porções mais distais desses leques aluviais, próximos à planície litorânea, em camadas com espessuras que variam de $0,40 \mathrm{a} 1,20 \mathrm{~m}$. Em alguns locais as areias foram encontradas sobrepostas às camadas de lamas (Fig. 47).

As areias apresentam-se com granulometria que varia de areia média a grossa e com quantidade de argila superior a $15 \%$. Também são comuns grânulos de quartzo e feldspatos subangulares a subarredondados, sendo raros os fragmentos líticos. São muito pobremente selecionadas e localmente apresentam granodecrescência ascendente e incipiente estratificação plano-paralela. 


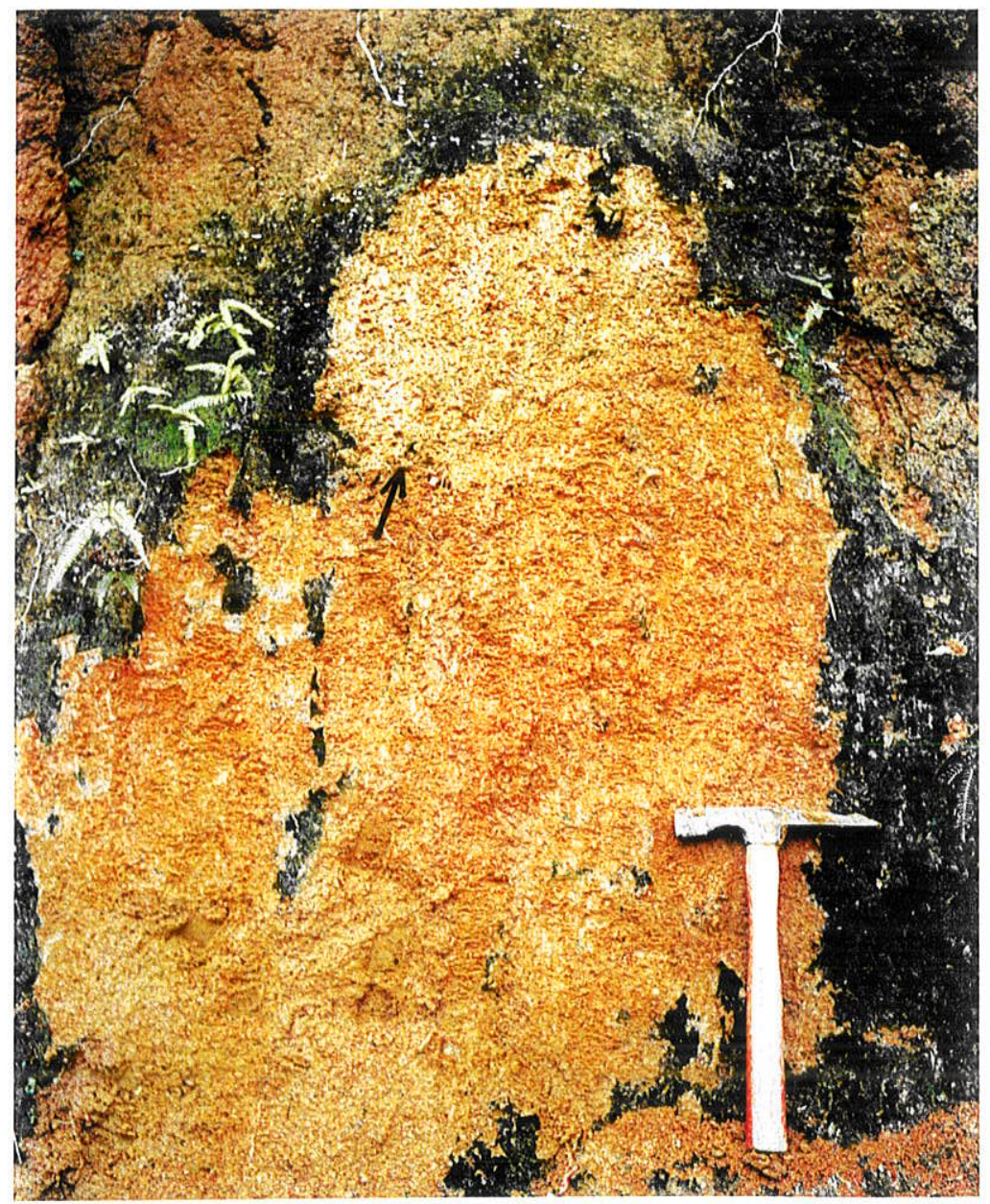

Figura 44: Cascalho sustentado por matriz do leque aluvial Caovi, apresentando clastos alterados de granito que se confundem com a matriz (ponto 11.3.92-03).

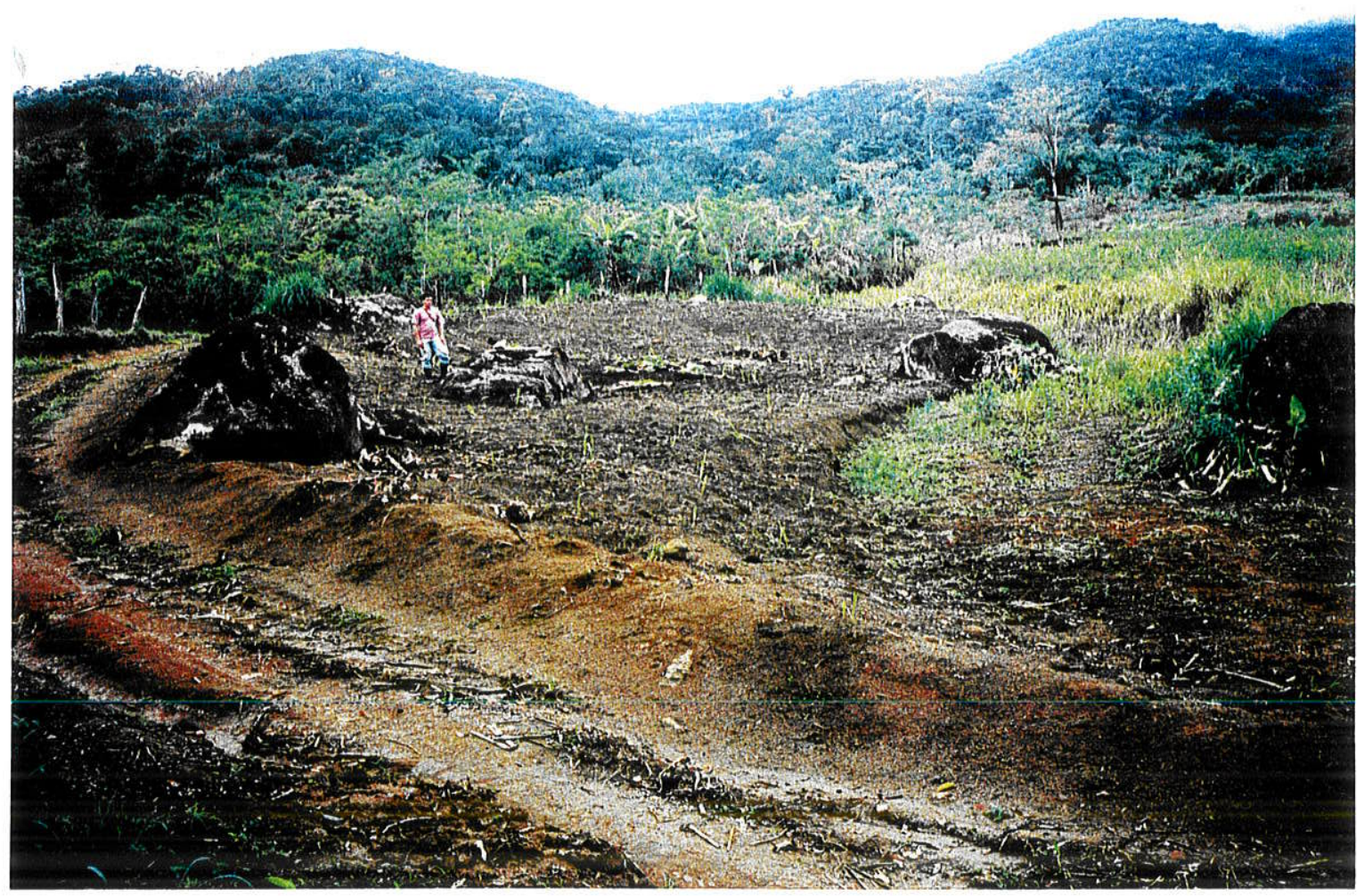

Figura 45: Blocos de cascalhos sustentados por matriz que ocorrem na superfície do leque aluvial Brejatuba (ponto 12.11.91-02). 


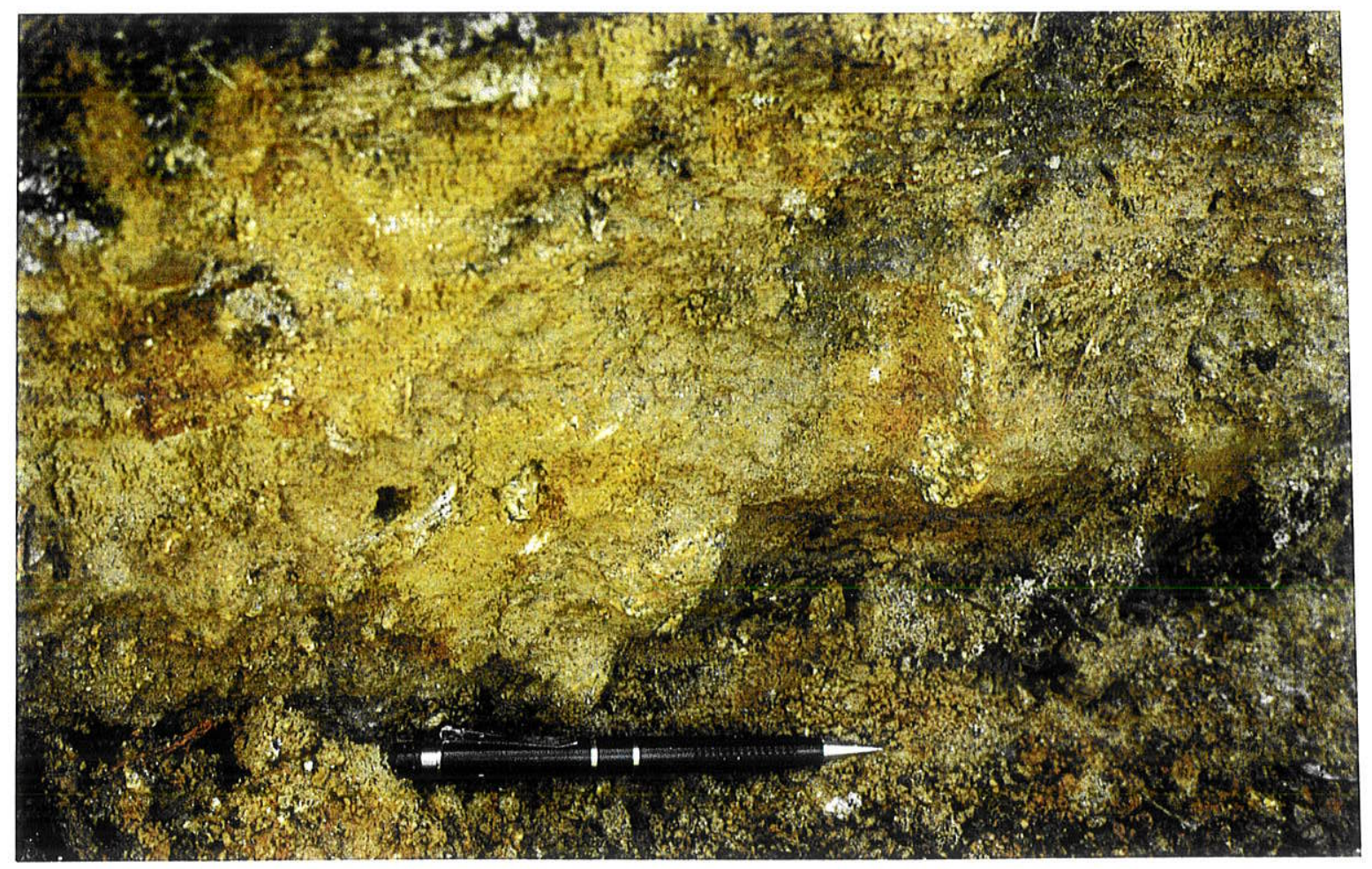

Figura 46: Detalhe de lama encontrada no leque aluvial Brejatuba, mostrando grânulos e seixos de fragmentos líticos (ponto 12.11.91-03).

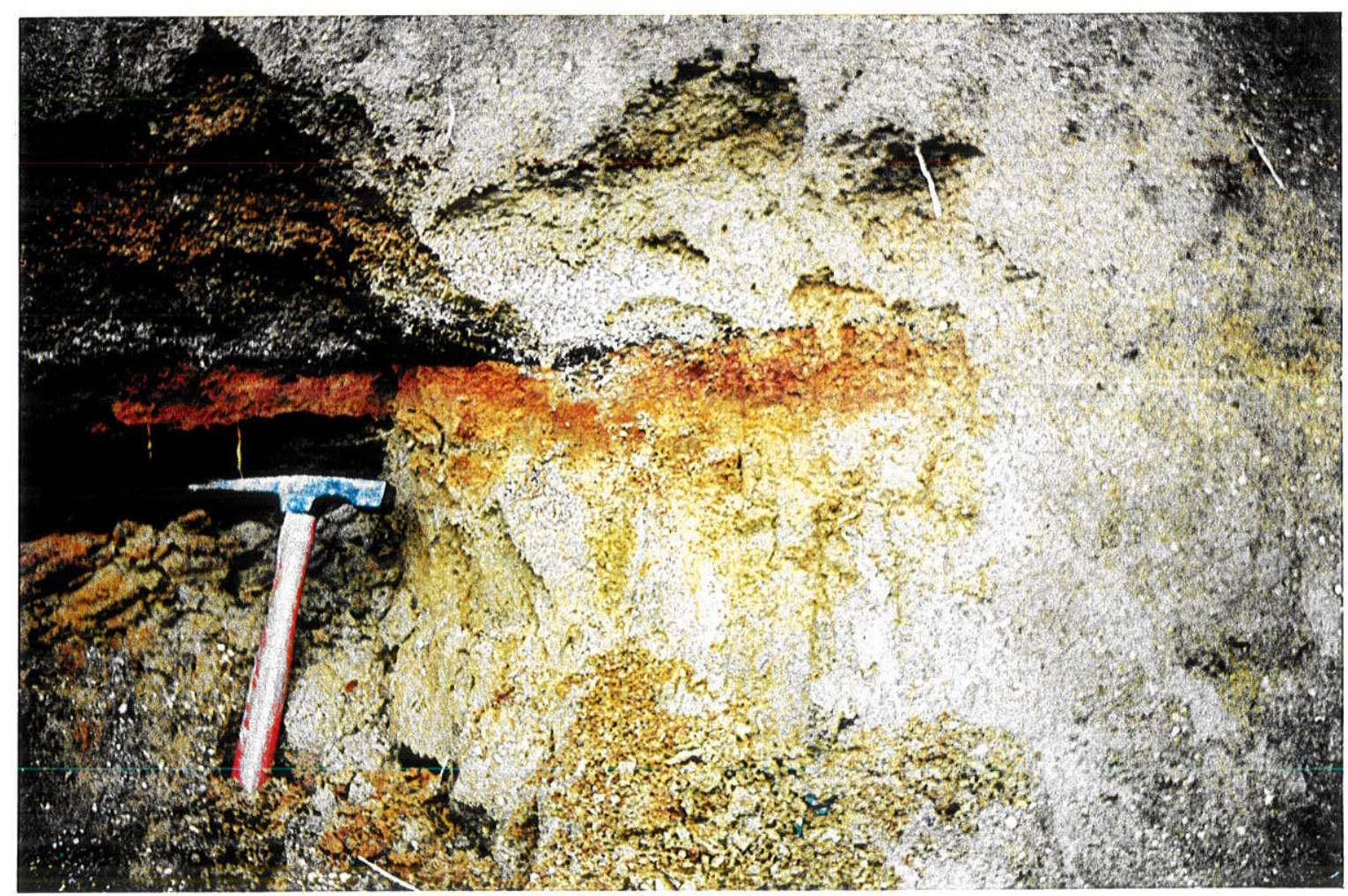

Figura 47: Camada de areia arcoziana sobre lama no leque aluvial Brejatuba (ponto 12.11.91-03). 


\subsubsection{Fósseis}

Nos trabalhos prévios que tratam desses depósitos, não existe qualquer registro sobre materiais fósseis. Durante os trabalhos de campo foram encontrados troncos, caules e folhas nos leques aluviais Colônia Pereira, Cambará/Cachoeirinha e Morretes. Os fósseis vegetais do leque aluvial Colônia Pereira ocorrem em camada de silte arenoso de até $0,65 \mathrm{~m}$ de espessura (Fig. 34), apresentando-se bem preservados, com estruturas macroscopicamente bem visíveis de fibras lenhosas nos troncos e caules e nervuras nas folhas.

Os fósseis vegetais do leque aluvial Cambará/Cachoeirinha ocorrem em camada de lama no leito do rio Camabará e também apresentam-se bem preservados, podendo se observar as fibras lenhosas dos troncos e caules e as nervuras das folhas.

No leque aluvial Morretes os fósseis vegetais também apresentam-se bem preservados, tendo sido encontrados em camada de argila síltica com espessura de $0,25 \mathrm{~m}$.

\subsection{PALEOCORRENTES}

Poucas foram as estratificações cruzadas que puderam ser medidas pois, tanto nos depósitos da Formação Alexandra como nos leques aluviais quaternários, o intemperismo alterou bastante as estruturas originais. Portanto, os resultados apresentados referem-se às medidas de orientação de seixos (ANEXO 3) realizadas em afloramentos da Formação Alexandra (ponto 13.2.92-01 e ponto 26.3.92-03, próximos ao rio Guaraqueçaba) e do leque aluvial Morretes (ponto 21.2.92-01, no rio Marumbi). Estes resultados tiveram como objetivo verificar as relações de orientação de seixos com a das paleocorrentes e, desta forma, subsidiar as análises de evolução paleogeográfica do litoral paranaense.

Para a Formação Alexandra, os resultados apresentam-se um pouco diferentes conforme os afloramentos amostrados. No ponto 13.2.92-01 a resultante do sentido de inclinação apresenta rumo N28E (Fig. 48), o que significa que a palecorrente deveria ter rumo de $\mathrm{S} 28 \mathrm{~W}$. Este sentido é praticamente paralelo ao rumo 
médio do fluxo atual do rio Guaraqueçaba (S23W). No ponto 26.3.92-03 os resultados mostram que a resultante média para o sentido de inclinação do eixo longo teria rumo N88E (Fig. 49), indicando que a paleocorrente teria rumo S88W. Isto mostra que a paleocorrente apresentava rumo diferente do rumo médio atual do rio Guaraqueçaba.
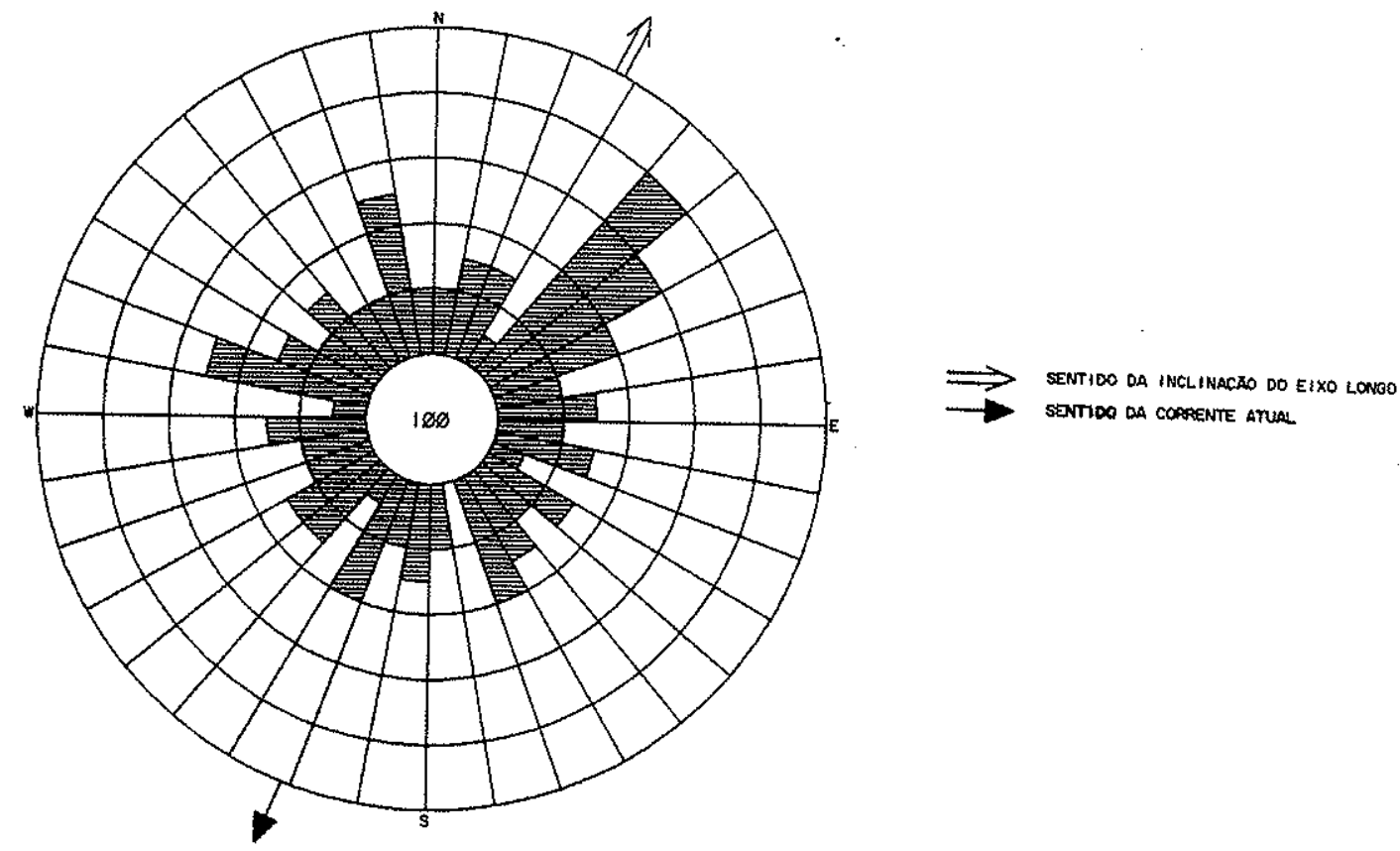

Figura 48: Diagrama de roseta para mediçóes de seixos da Formação Alexandra. Afloramento situado à margem da estrada para Batuva (ponto 13.2.92-01).

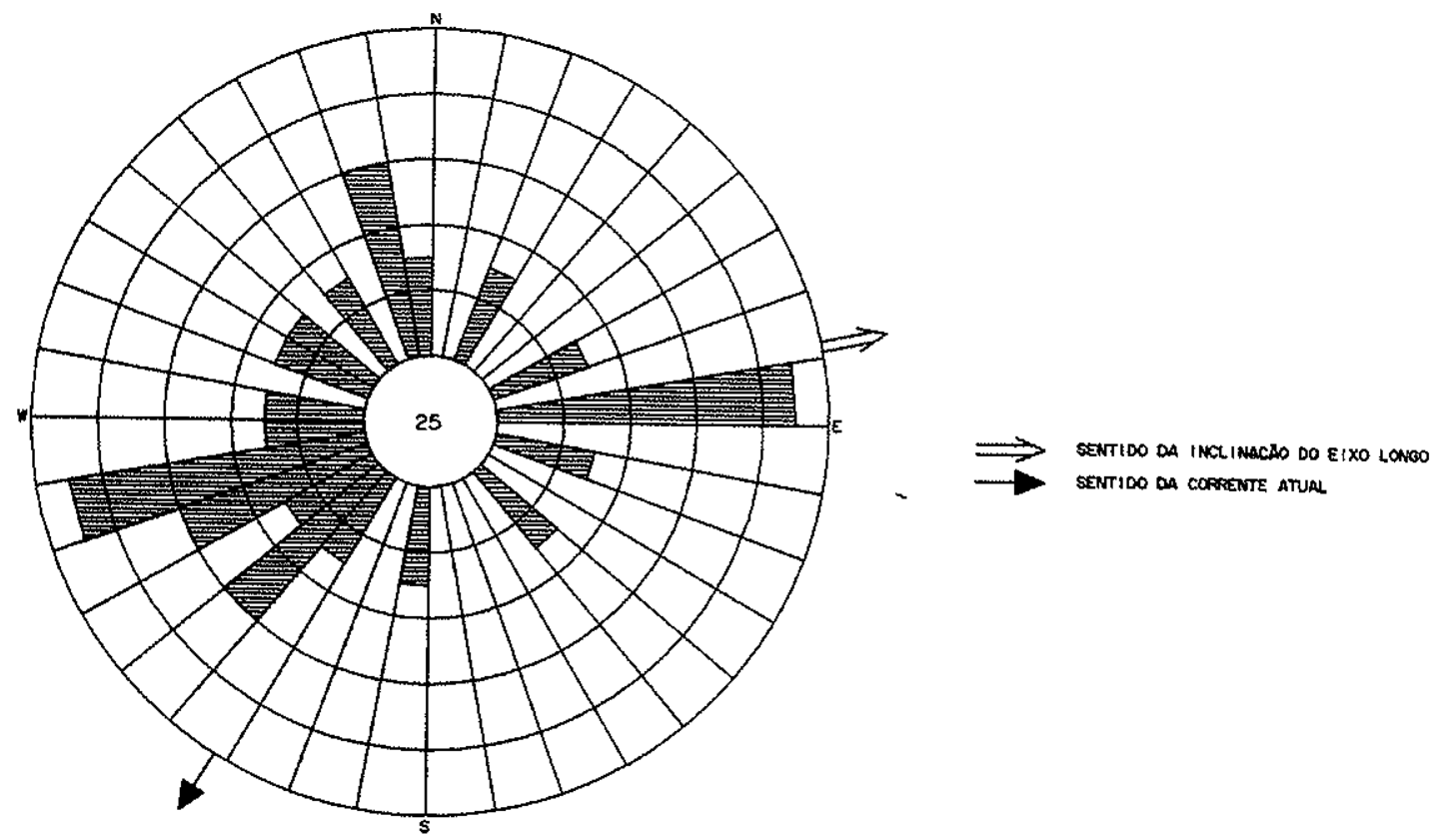

Figura 49: Diagrama de roseta para medições de seixos da Formação Alexandra. Afloramento situado na estrada para Guaraqueçaba (ponto 26.3.92-03). 
Deve-se levar em conta que, além de estarem distanciados cerca de $3 \mathrm{~km}$, o número de medidas foi bem menor que no afloramento anterior e o fator de consistência para este afloramento $(0,053)$ mostra uma alta dispersão nas medidas, em comparação com o outro afloramento $(0,103)$. Pode-se verificar também que no diagrama do ponto 26.3.92-03 (Fig. 49), tem-se pelo menos quatro modas de orientação preferencial, sendo que três se apresentam em rumos bastante diferentes da resultante média.

Para o afloramento situado no rio Marumbi (Fig. 50), o fator de consistência foi mais alto $(0,259)$ e a resultante média de inclinação de seixos indica rumo da paleocorrente para S6W. No entanto, o sentido médio da corrente atual apresenta rumo de N70E, podendo indicar que o antigo curso do rio Marumbi teria sentido entre contrário a transversal ao atual fluxo, já que a diferença entre as medidas é de aproximadamente $110^{\circ}$.

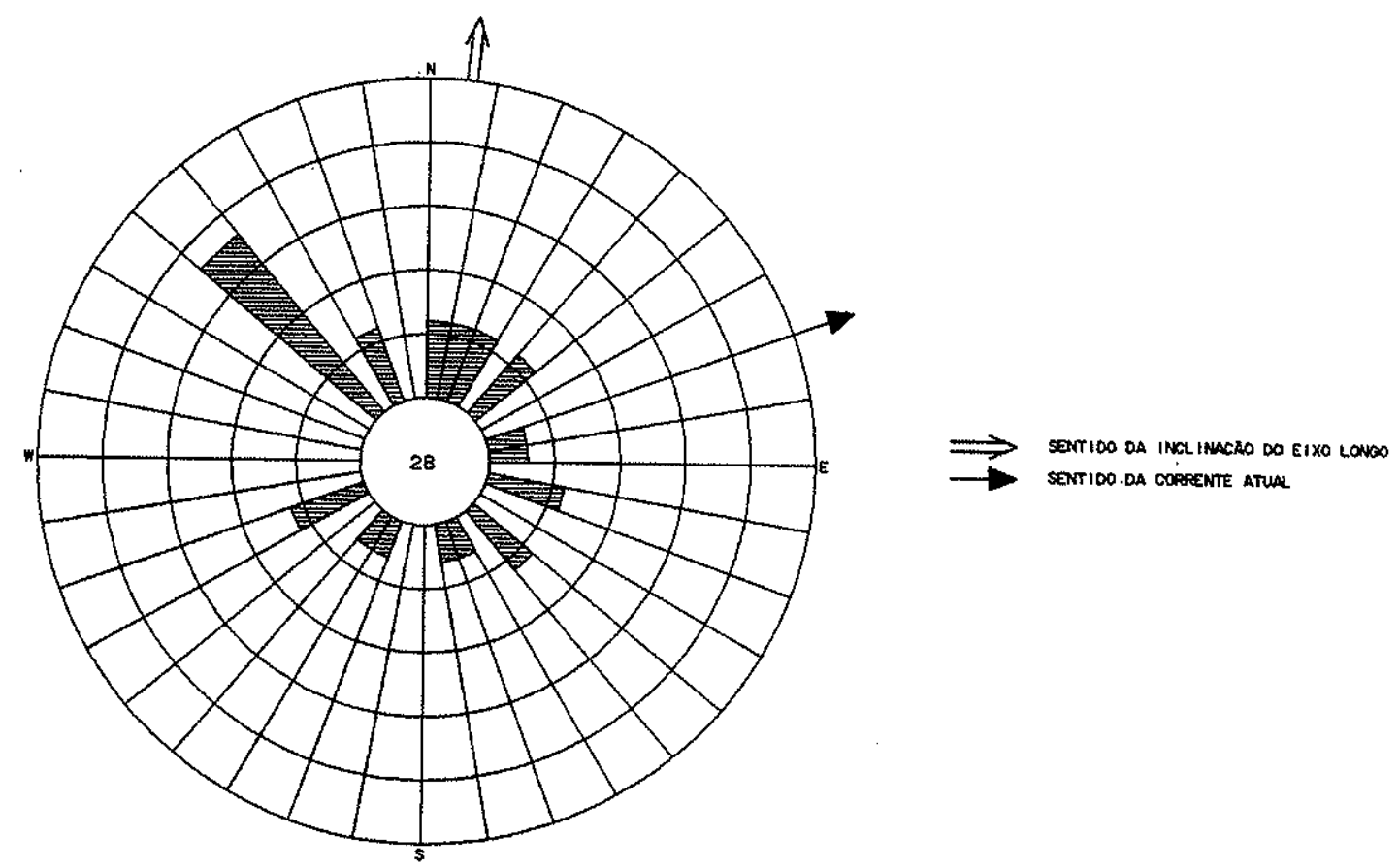

Figura 50: Diagrama de roseta para medições de seixos do leque aluvial Morretes. Afloramento situado à margem do rio Marumbi (ponto 21.2.92-01). 
As disperssões verificadas para os afloramentos da região de Guaraqueçaba parecem refletir a fácies de sistema fluvial entrelaçado, o que poderia explicar medidas de baixa consistência encontradas na Formação Alexandra para esta região. Mesmo apresentando rumo diferente ao rumo atual do rio Guaraqueçaba, o resultado do ponto 26.3.92-03 situa-se no mesmo semicírculo $\mathrm{SW}$, podendo ter sido depositado em uma sinuosidade do antigo canal do rio Guaraqueçaba. 


\subsection{ESTUDOS SEDIMENTOLÓGICOS}

\subsubsection{Análises Granulométricas}

Foram realizadas análises granulométricas de 68 amostras da Formação Alexandra, tendo sido 44 amostras coletadas nas proximidades da PR 508 e 24 amostras coletadas na região de Guaraqueçaba. Da mesma forma que no item 6.2 , os resultados aqui apresentados levaram em conta a região de coleta do sedimento, dividindo-se em Tal (Mat) e Tal (Gua). Nos leques aluviais quaternários pesquisados, foram feitas análises granulométricas de 76 amostras.

A relação das amostras analisadas, conforme as diferentes unidades estratigráficas, encontra-se no ANEXO 1. Nesta relação também são apresentados os resultados das análises para cada amostra, tais como, os parâmetros estatísticos de Folk \& Ward (1957), além da mediana e porcentagens em peso das classes texturais de seixos, grânulos, areia e silte + argila, a classificação que foi adotada em campo e a classificação de Shepard (1954).

$\mathrm{Na}$ Formação Alexandra as lamas e as areias grossas são predominantes, enquanto que a areia arcoziana ocorre subordinadamente. Na classificação de Shepard (1954), as lamas referem-se às argilas arenosas enquanto que as areias grossas e arcozianas correspondem às areias argilosas. Nos leques aluviais predominam as areias arcozianas que na classificação de Shepard (op. cit.), aparecem geralmente como areia. Entretanto, nos leques aluviais Brejatuba, Pombas, Caovi e Miranda os cascalhos sustentados por matriz e as areias arcozianas são predominantes.

Considerando a porcentagem média das classes texturais por unidade estratigráfica (Fig. 51), pode-se notar que na Formação Alexandra, tanto da região de Alexandra (Tal-Mat) como da região de Guaraqueçaba (Tal-Gua), os teores de areia e silte+argila se assemelham bastante, embora na região de Guaraqueçaba ocorram porcentagens maiores de grânulos e seixos. Os leques aluviais Colônia Pereira (Qcp), Cambará $(\mathrm{Qc})$, Cachoeirinha (Qca) e Cubatão (Qcb) são semelhantes entre si, 
diferenciando-se do leque Morretes (Qm), que possui a maior frequência de seixos de todas as unidades analisadas. Entretanto, deve-se considerar que neste leque foram coletadas apenas 4 amostras, devido a escassez de afloramentos na região onde esta unidade está situada. No caso dos leques aluviais Brejatuba $(\mathrm{Qb})$, Pombas $(\mathrm{Qp})$, Caovi (Qcao) e Miranda (Qmi), nota-se que não existe semelhança com os outros leques. Esta diferença pode ser notada também em campo, ressaltando-se que o leque Brejatuba é a unidade com maior variedade de sedimentos encontradas neste grupo, inclusive com maior quantidade de afloramentos.

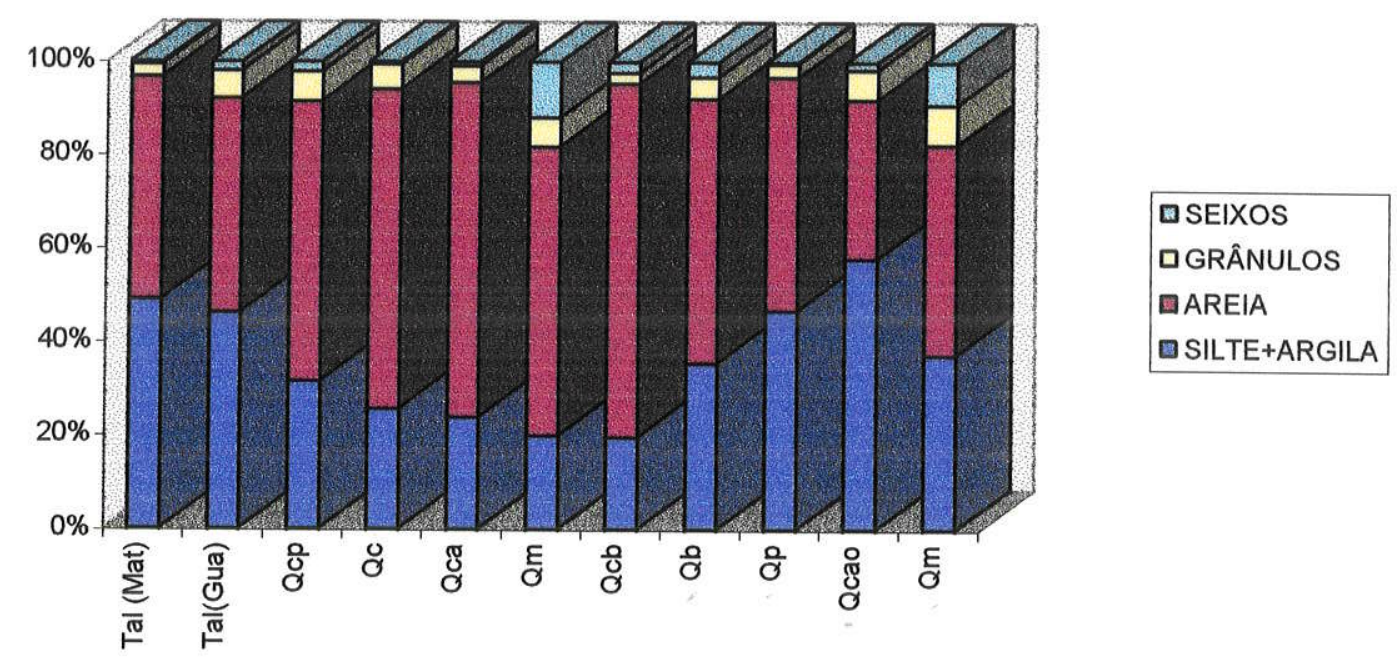

\section{Figura 51: Frequências porcentuais médias das classes texturais por unidade estratigráfica}

\subsubsection{Parâmetros de Folk \& Ward (1957)}

Na Fig. 52 são mostrados os valores médios dos parâmetros de Folk \& Ward (op. cit.) por unidade estratigráfica, notando-se que a Formação Alexandra, apesar dos valores de diâmetro médio, mediana e percentil da região de Guaraqueçaba serem pouco mais baixos que da região de Alexandra, são ainda bastante similares.

Os leques aluviais Colônia Pereira, Cambará e Cachoeira mostram-se com características semelhantes entre si, apesar dos valores de diâmetro médio, mediana e percentil do leque Cambará serem pouco mais baixos. O mesmo não acontece com os 
leques aluviais Morretes e Cubatão, onde o primeiro apresenta valores de diâmetro médio e mediana mais altos e valores de curtose e percentil mais baixos que os outros leques, enquanto que no leque aluvial Cubatão os valores de desvio padrão são mais baixos e os de curtose e percentil são mais altos do que a média dos outros leques.

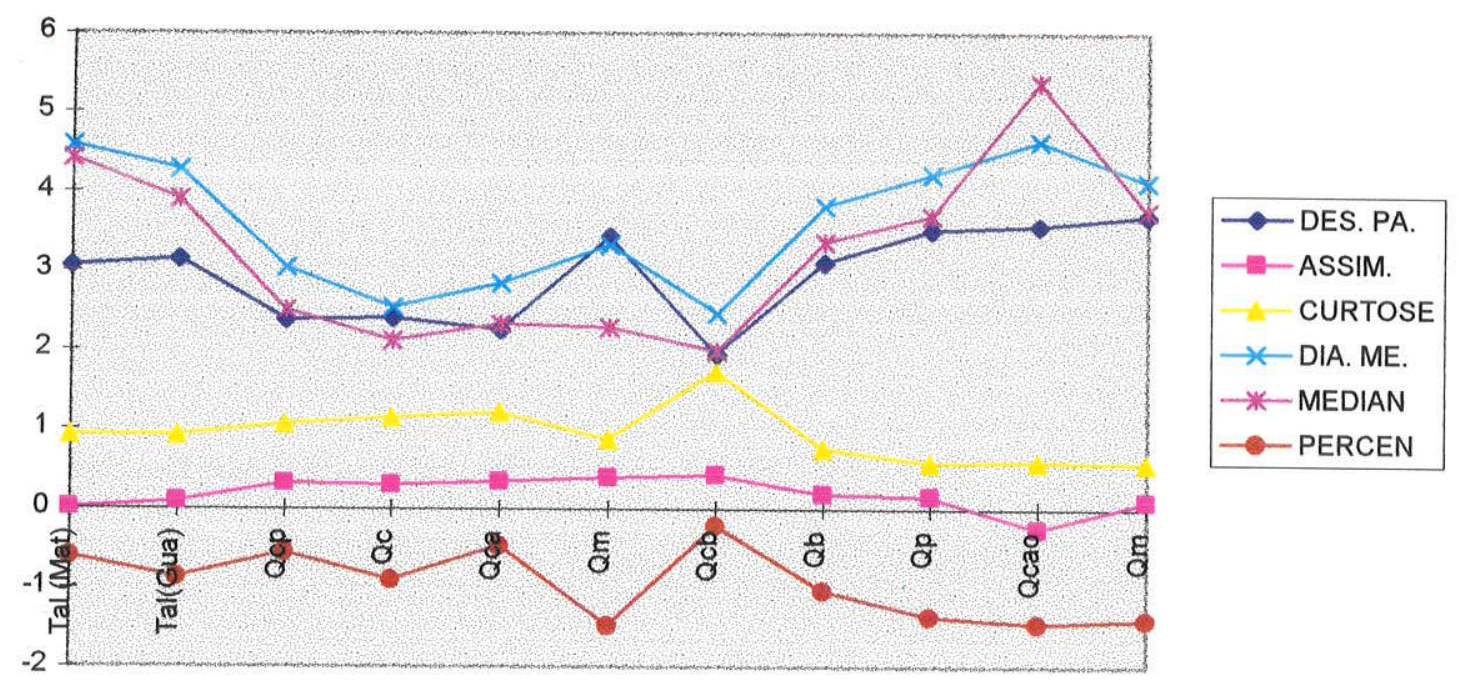

Figura 52: Valores médios dos parâmetros de Folk \& Ward (1957) por unidades estratigráficas (valores em $\phi$ para diâmetro médio e desvio padrão)

Excetuando-se as amostras do leque aluvial Caovi, que apresenta valores muito diferentes de diâmetro médio, mediana e assimetria, os valores dos parâmetros estatísticos dos leques aluviais Brejatuba, Pombas e Miranda são semelhantes. Para este gráfico deve-se ressaltar algumas características, como os valores de desvio padrão que se apresentam geralmente muito pobremente selecionados, com exceção do leque aluvial Cubatão que é pobremente selecionado. Nesta unidade, os valores de curtose aparecem como muito leptocúrtica, enquanto que as outras unidades apresentam-se mais platicúrticas.

Além dos gráficos de parâmetros de Folk \& Ward (1957) que são apresentados a seguir, também foi tentada a construção de gráficos com os outros pares de parâmetros, como diâmetro médio $\mathrm{x}$ curtose ou desvio padrão $\mathrm{x}$ diâmetro médio, mas não mostraram tão boa visualização do comportamento das amostras como os parâmetros que são apresentados a seguir. 
As Figs. 53 a 57 representam gráficos dos parâmetros estatísticos médios de Folk \& Ward (1957), para diâmetro médio $\mathrm{x}$ mediana e mediana $\mathrm{x}$ assimetria da Formação Alexandra.

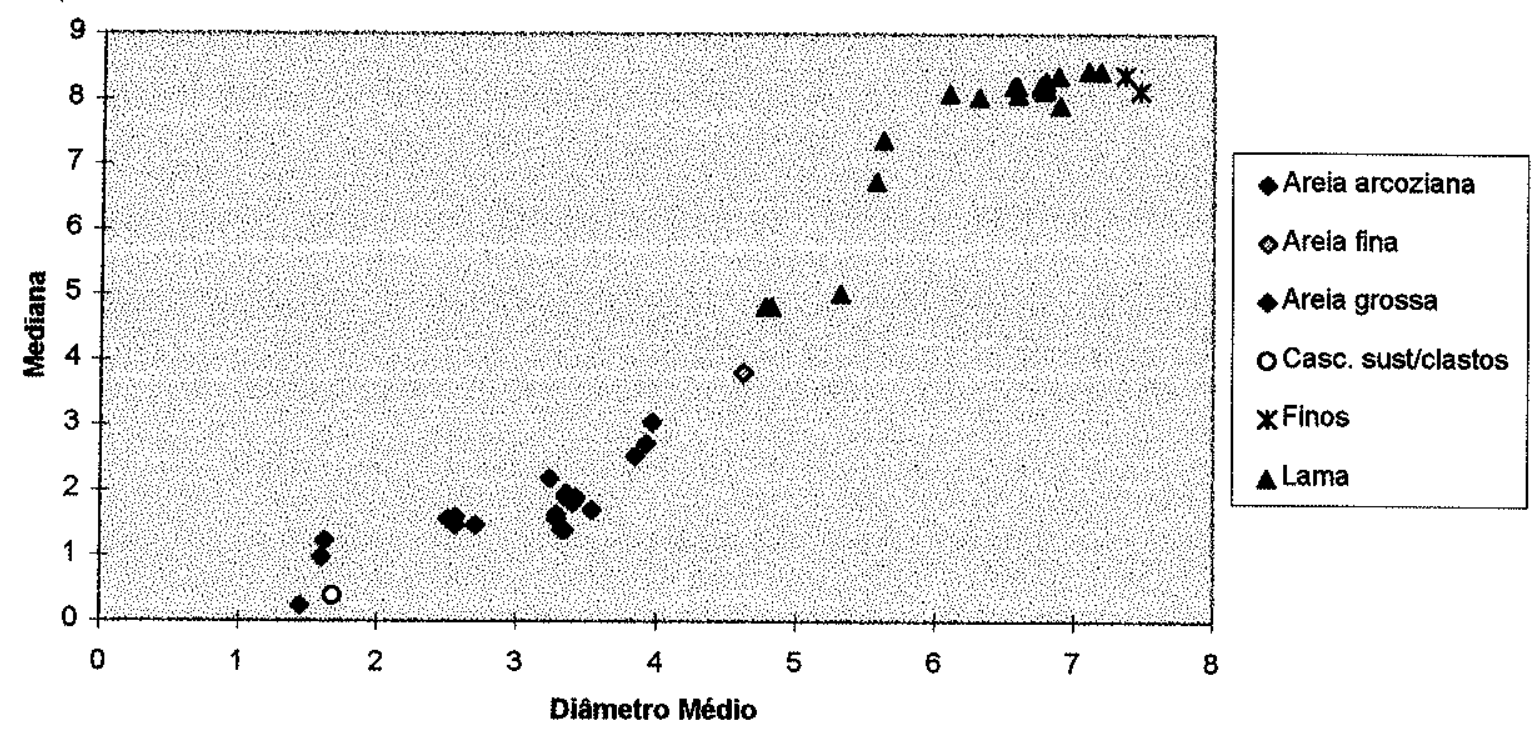

Figura 53: Parâmetros estatísticos médios de Folk \& Ward (1957) da Formação Alexandra para diâmetro médio $x$ mediana de amostras da região de Alexandra (valores em $\phi$ )

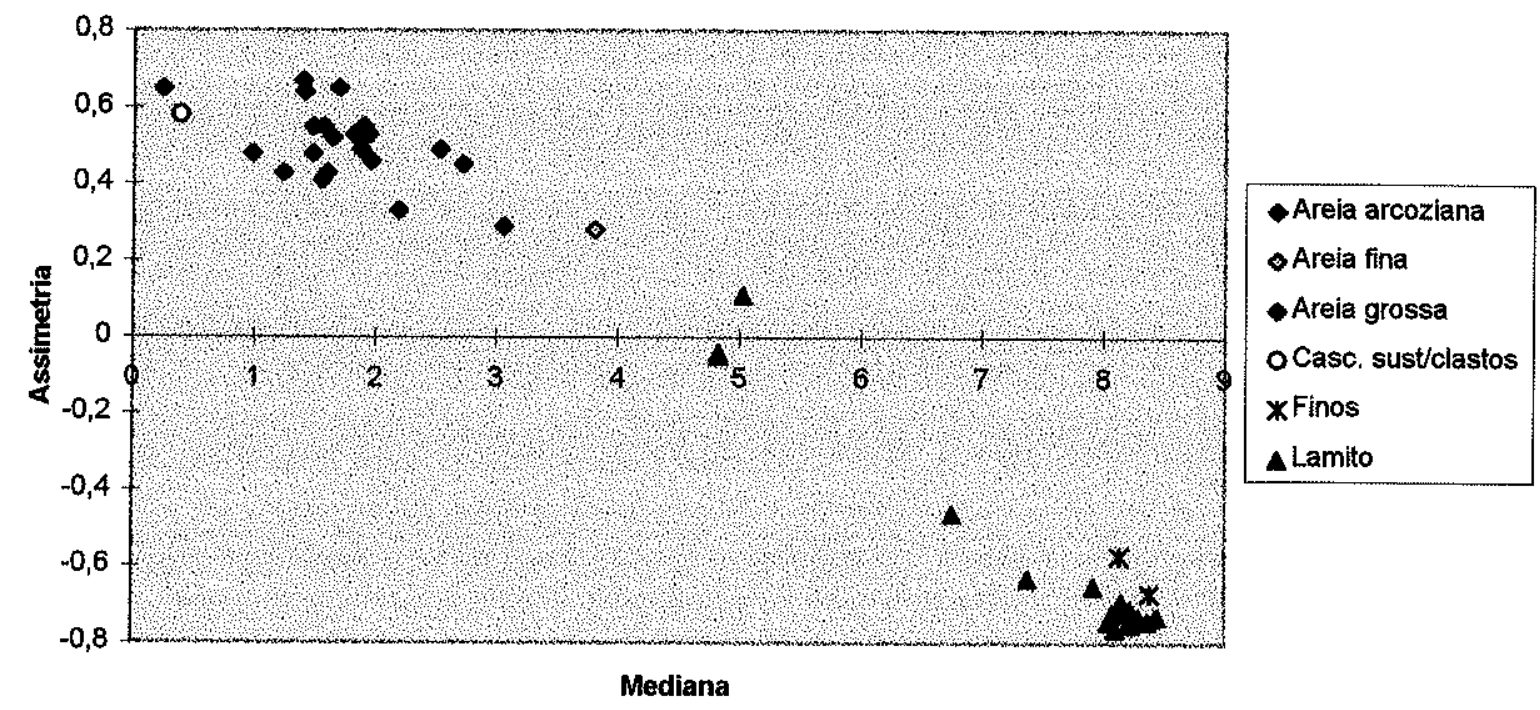

Figura 54: Parâmetros estatísticos médios de Folk \& Ward (1957) da Formação Alexandra para mediana $x$ assimetria de amostras da região de Alexandra (Valores em $\phi$ ) 
Os gráficos desta formação são apresentados separadamente por região para comparação do comportamento de seus padrões. Para o conjunto das amostras foram construídos outros gráficos, procurando ressaltar a similaridade entre as populações de amostras de ambas regiões.

No caso da Formação Alexandra (região de Alexandra) (Figs. 53 e 54), pode-se verificar que, pelo menos duas populações, encontram-se bem definidas nos gráficos. Na Fig. 53 encontra-se uma população composta principalmente de lamas e outra população composta principalmente por areias arcozianas e areias grossas. Na interface dessas duas populações parece ocorrer outra população com características transicionais entre as duas. Da mesma forma, na Fig. 54 essas populações também estão bem discriminadas, onde a as amostras de lamas apresentam assimetria muito negativa, enquanto que as areias apresentam assimetria muito positiva. Aqui também são encontradas algumas amostras de lamas que se localizam na zona de transição entre as duas populações mais discriminadas.

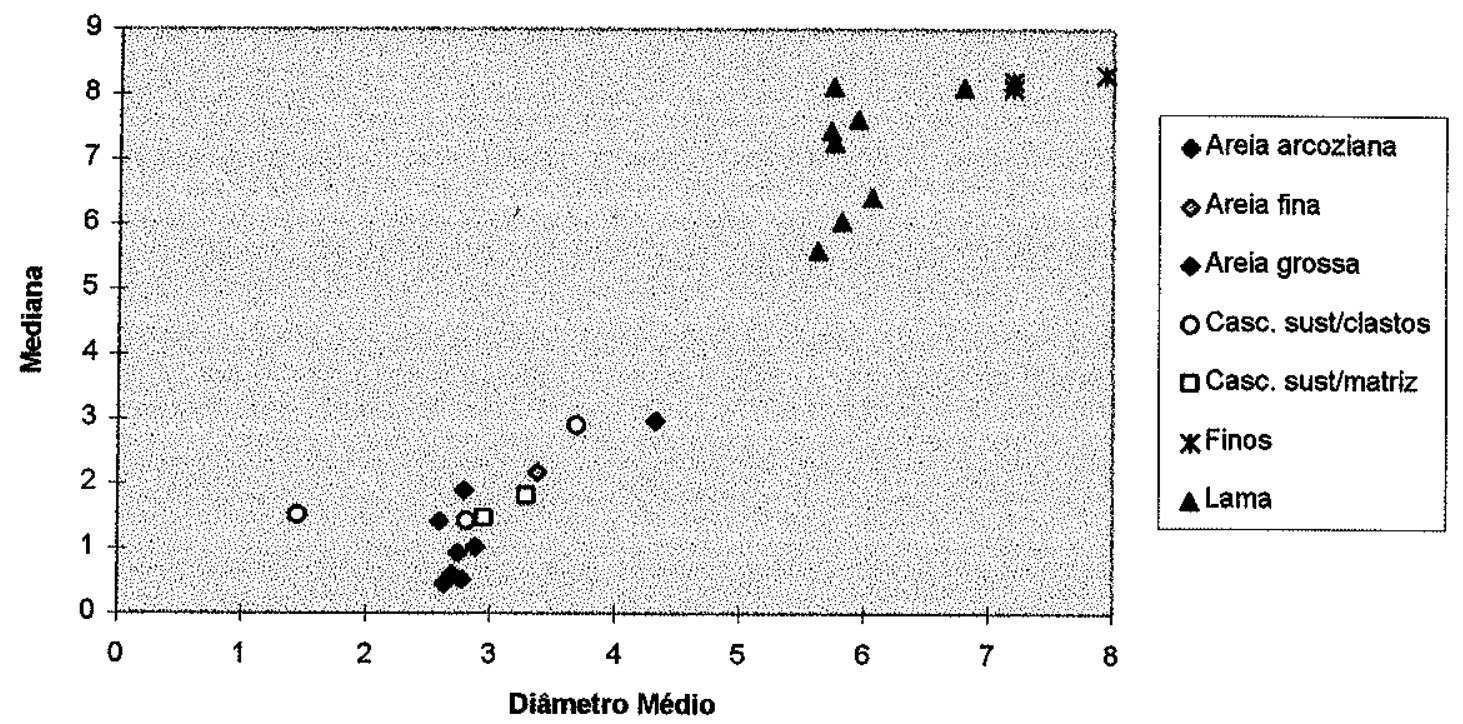

Figura 55: Parâmetros estatísticos médios de Folk \& Ward (1957) da Formação Alexandra para diâmetro médio $x$ mediana de amostras da região de Guaraqueçaba (valores em $\phi$ )

Na Formação Alexandra (região de Guaraqueçaba) (Figs. 55 e 56), os gráficos são bastante similares aos da mesma formação na região de Alexandra. 
Apesar das amostras de areias se apresentarem de forma mais dispersas que no gráfico da região de Alexandra, a presença de lamas na zona de transição entre as duas populações também é verificada.

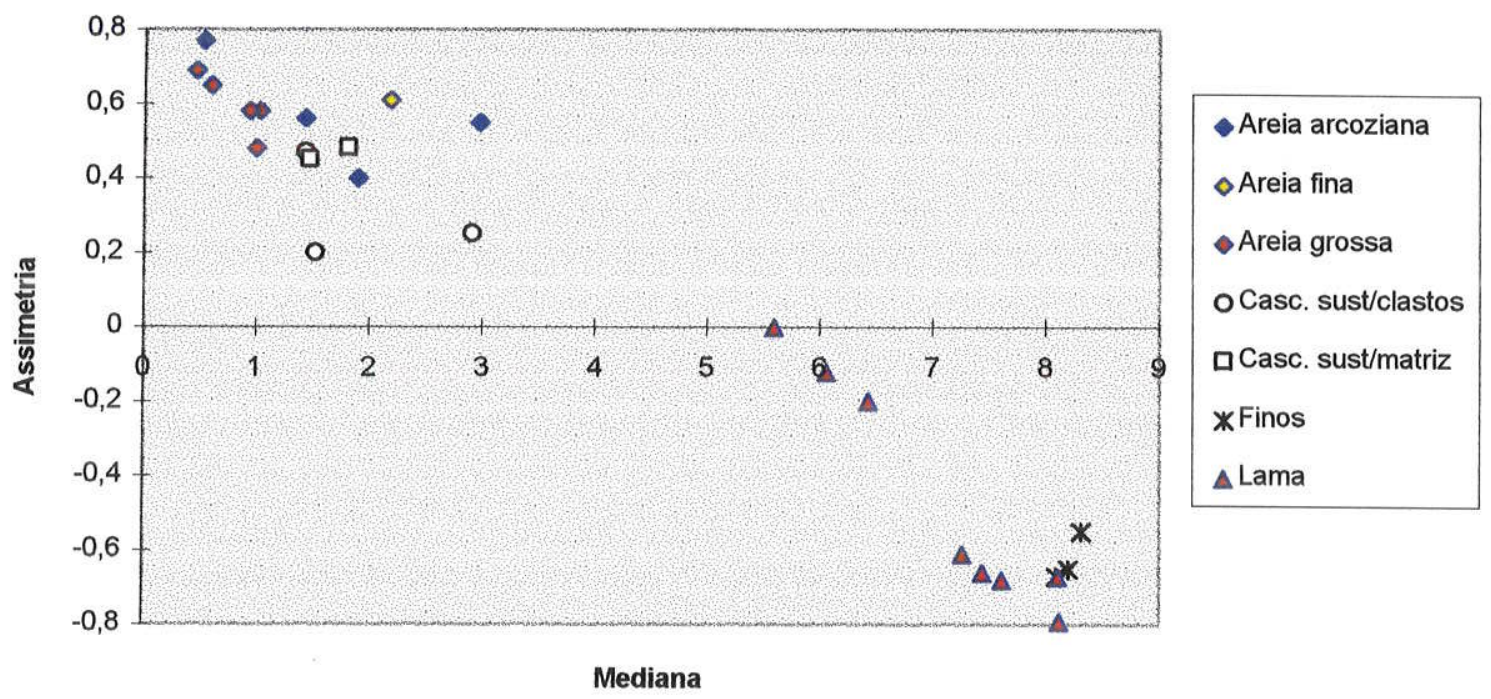

Figura 56: Parâmetros estatísticos médios de Folk \& Ward (1957) da Formação Alexandra para mediana $x$ assimetria de amostras da região de Guaraqueçaba (Valores em $\phi$ )

Nas Figs. 57 e 58 são apresentados parâmetros estatísticos médios de Folk \& Ward (1957) para todas as amostras da Formação Alexandra, incluindo as da região de Alexandra e de Guaraqueçaba.

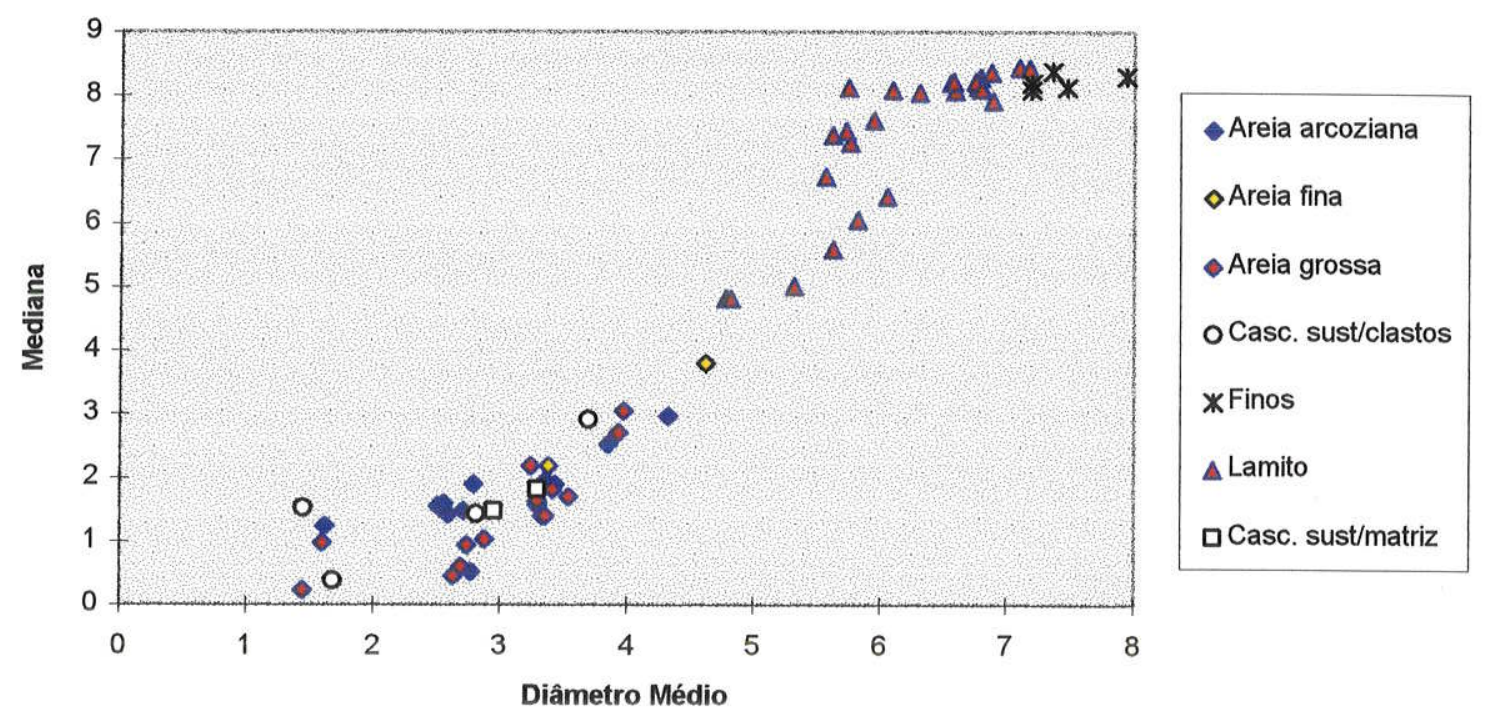

Figura 57: Parâmetros estatísticos médios de Folk \& Ward (1957) da Formação Alexandra para diâmetro médio $x$ mediana para todas as amostras analisadas (valores em $\phi$ ) 
Neste caso, o gráfico de diâmetro médio $\mathrm{x}$ mediana apresentou-se sem separação entre as populações, mas as amostras de lamas e de areias ficaram em posições bem definidas, acompanhando a tendência já observada em outros gráficos.

Situação semelhante foi observada no gráfico de mediana $\mathrm{x}$ assimetria (Fig. 58), com tendências análogas às observadas nos outros gráficos de amostras da Formação Alexandra.

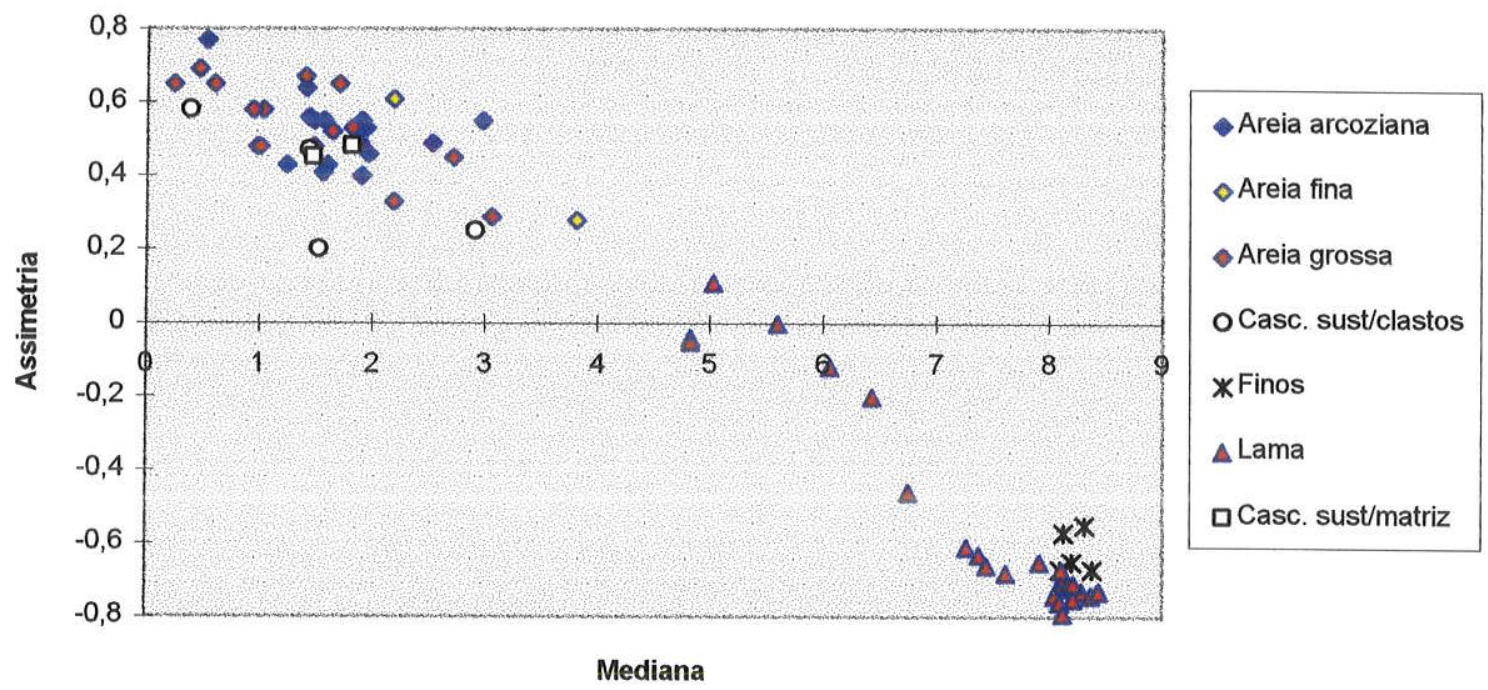

Figura 58: Parâmetros estatísticos médios de Folk \& Ward (1957) da Formação Alexandra para mediana $\mathbf{x}$ assimetria de todas as amostras analisadas (valores em $\phi$ )

Nas figuras 59 a 66 são apresentados os valores médios dos parâmetros de Folk \& Ward (1957) para diâmetro médio $\mathrm{x}$ mediana e mediana $\mathrm{x}$ assimetria dos leques aluviais quaternários estudados neste trabalho.

No caso do gráfico para diâmetro médio e mediana do leque Colônia Pereira (Fig. 59), as lamas e cascalhos apresentam os valores mais elevados e as areias os menores valores. Entretanto, para os parâmetros médios de mediana e assimetria (Fig. 60), não se verifica esta tendência, pois as amostras apresentam-se muito dispersas, não definindo qualquer agrupamento. 


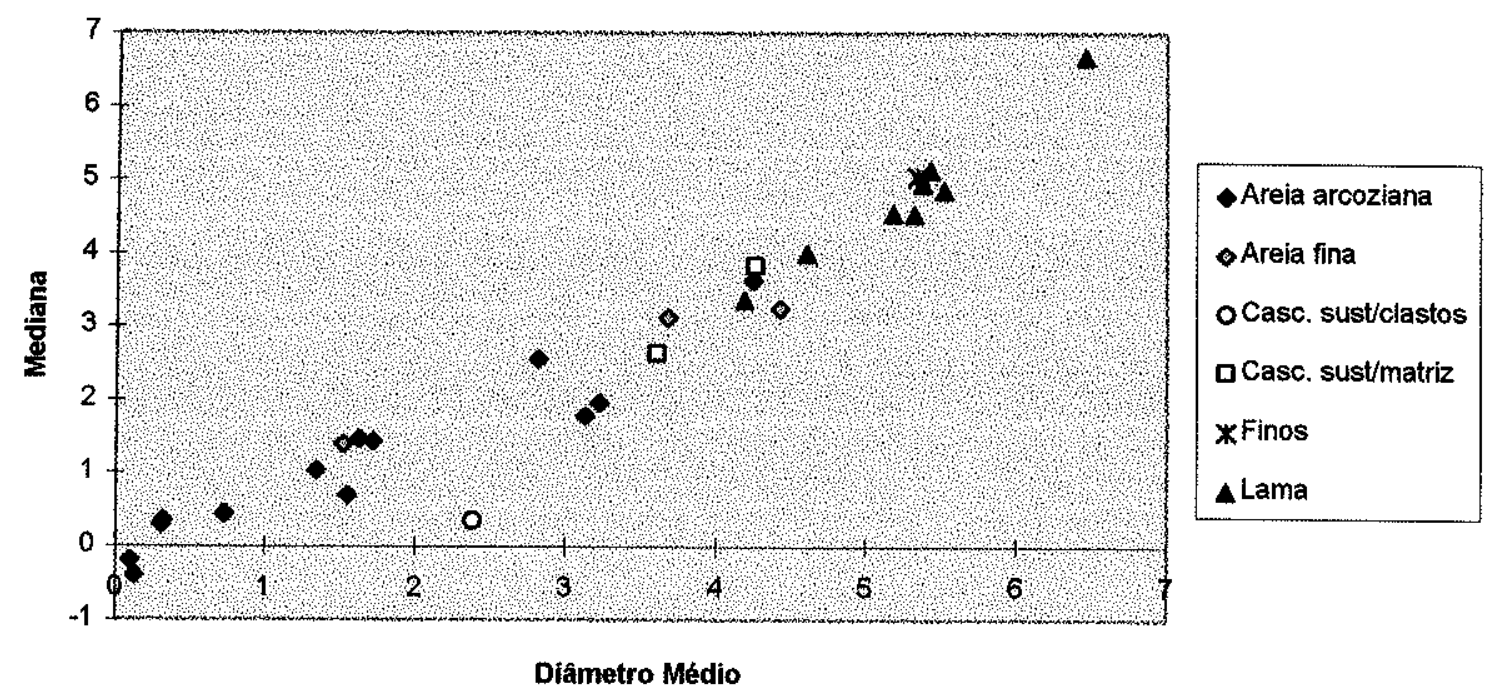

Figura 59: Parâmetros estatísticos médios de Folk \& Ward (1957) do leque aluvial Colônia Pereira para diâmetro médio $\mathrm{x}$ mediana (valores em $\phi$ )

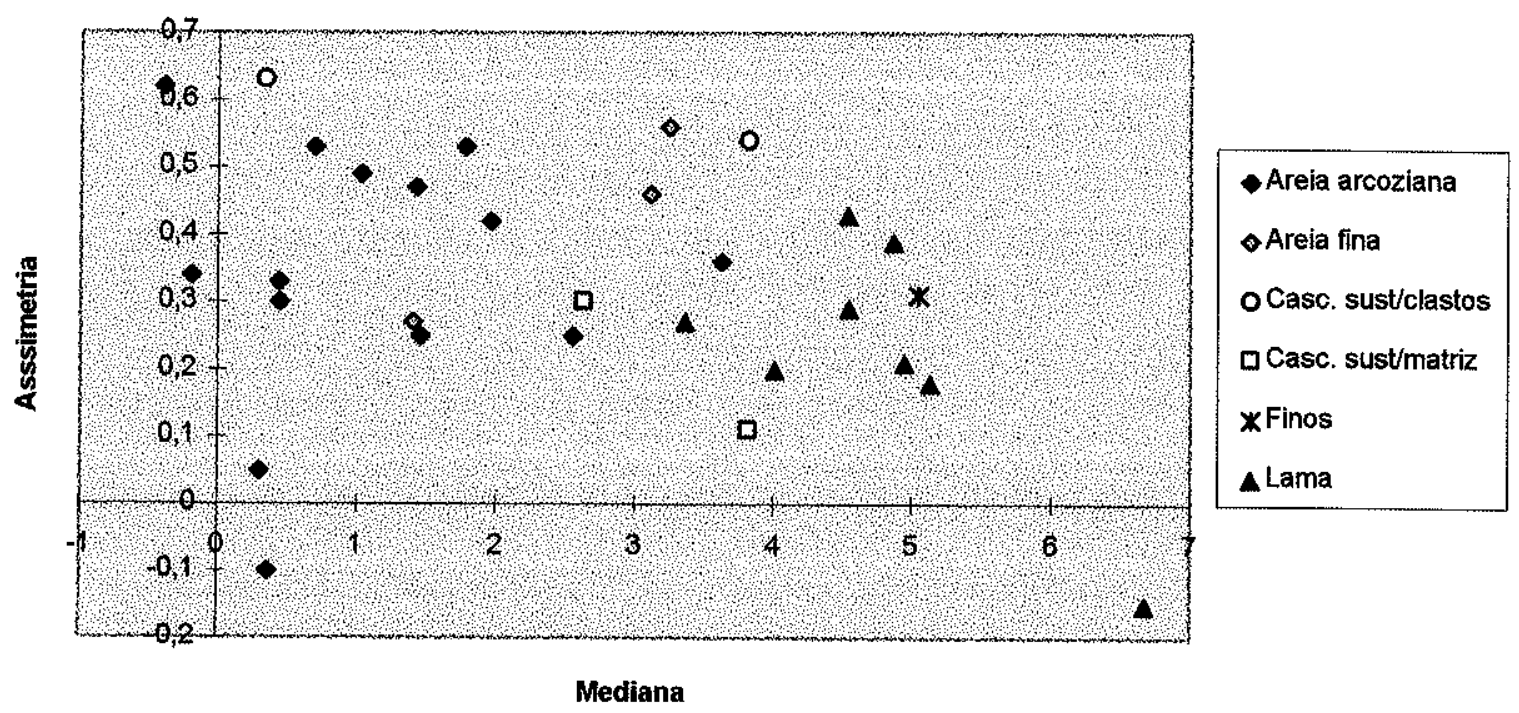

Figura 60: Parâmetros estatísticos médios de Folk \& Ward (1957) do leque aluvial Colônia Pereira para mediana $x$ assimetria (valores em $\phi$ )

Os leques aluviais Cambará e Cachoeirinha são apresentados em um só gráfico, já que em campo constituem leques coalescentes. 


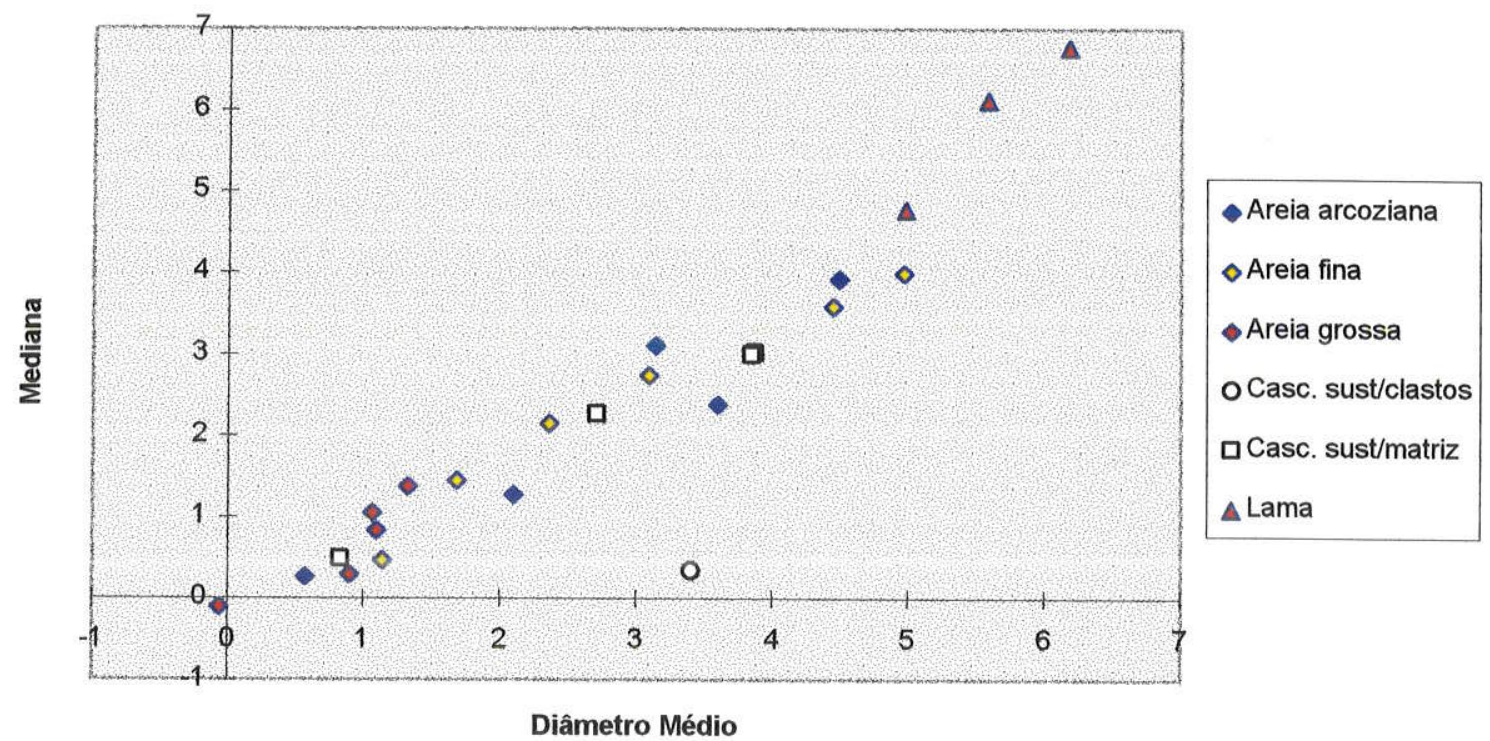

Figura 61: Parâmetros estatísticos médios de Folk \& Ward (1957) dos leques aluviais Cambará e Cachoeirinha para diâmetro médio $\mathrm{x}$ mediana (valores em $\phi$ )

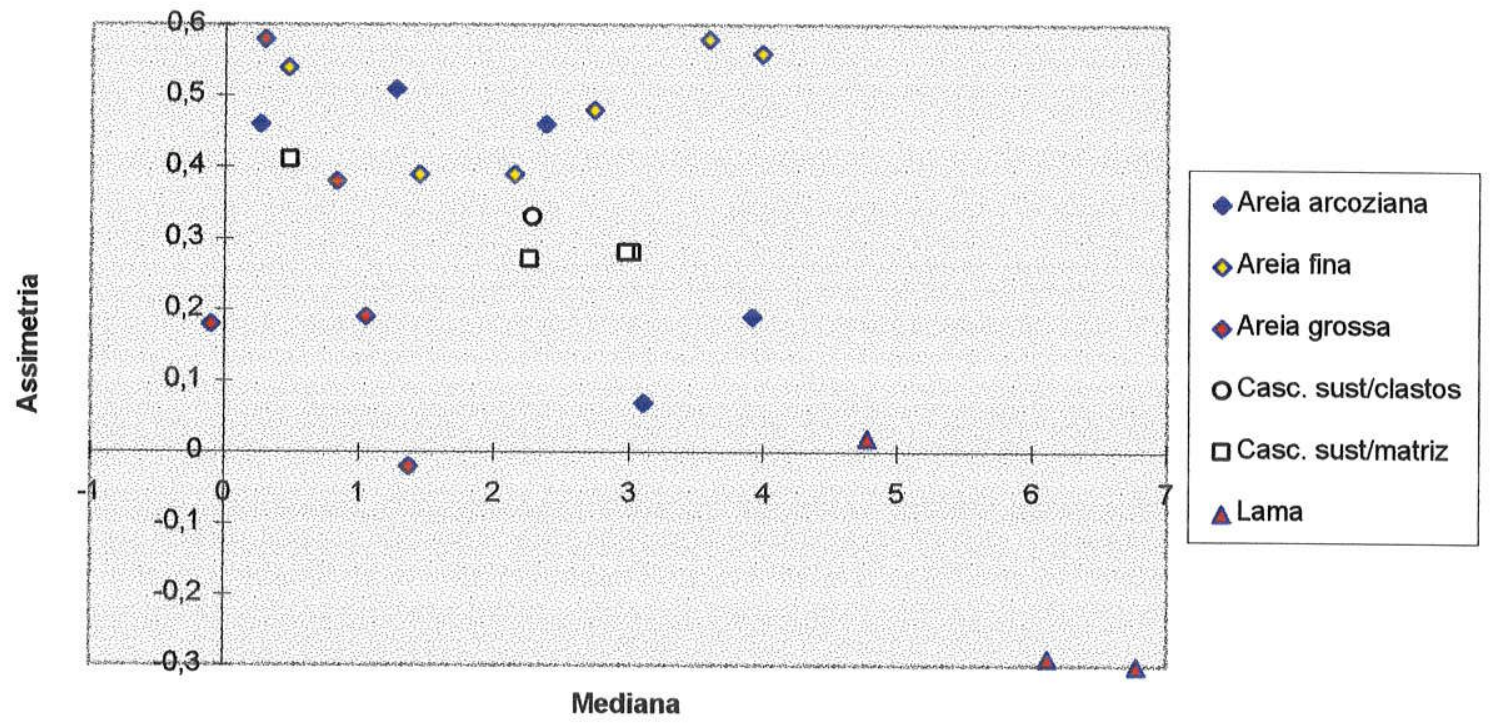

Figura 62: Parâmetros estatísticos médios de Folk \& Ward (1957) dos leques aluviais Cambará e Cachoeirinha para mediana $x$ assimetria (valores em $\phi$ )

Nos leques aluviais Cambará e Cachoeirinha (Figs. 61 e 62), excetuando-se a areia fina que ocorre bastante dispersa, também se observaram as tendências observadas nos gráficos do leque aluvial Colônia Pereira. 


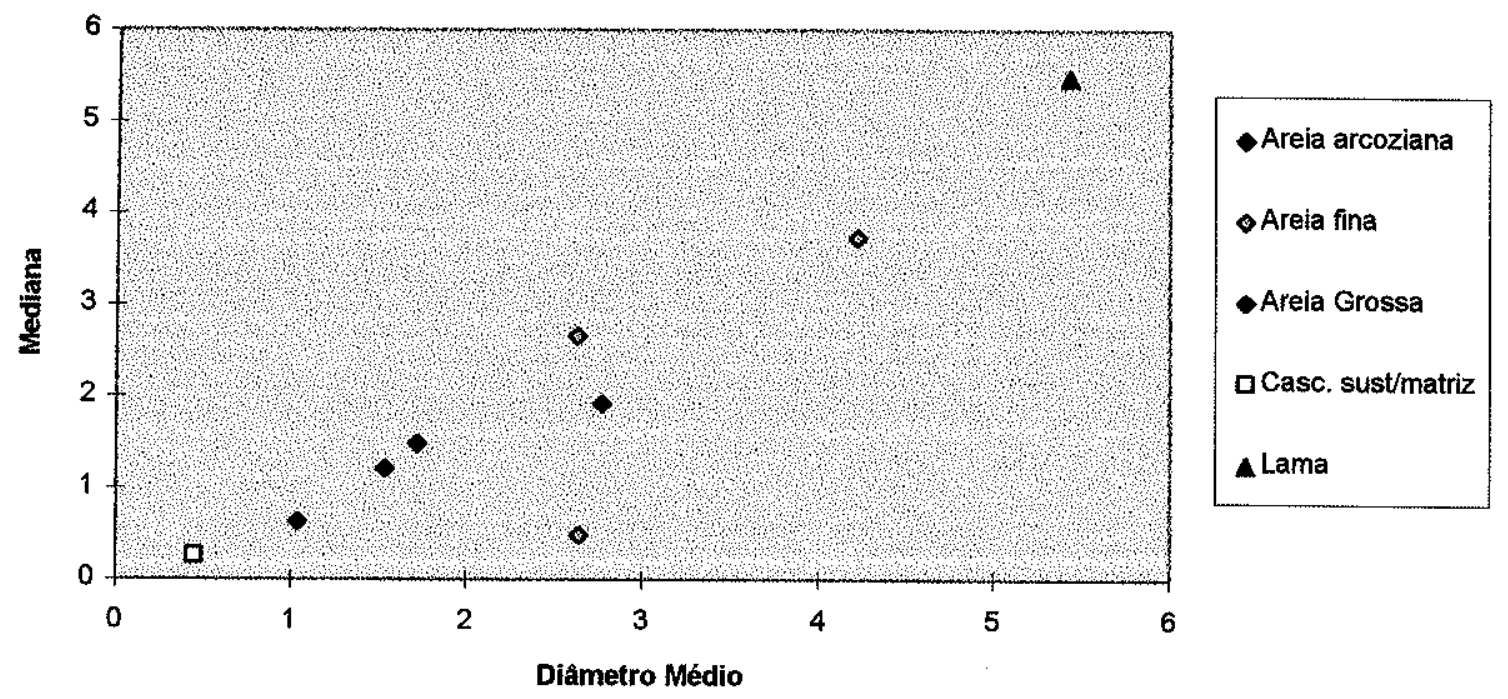

Figura 63: Parâmetros estatísticos médios de Folk \& Ward (1957) do leque aluvial Cubatão para diâmetro médio $x$ mediana (valores em $\phi$ )

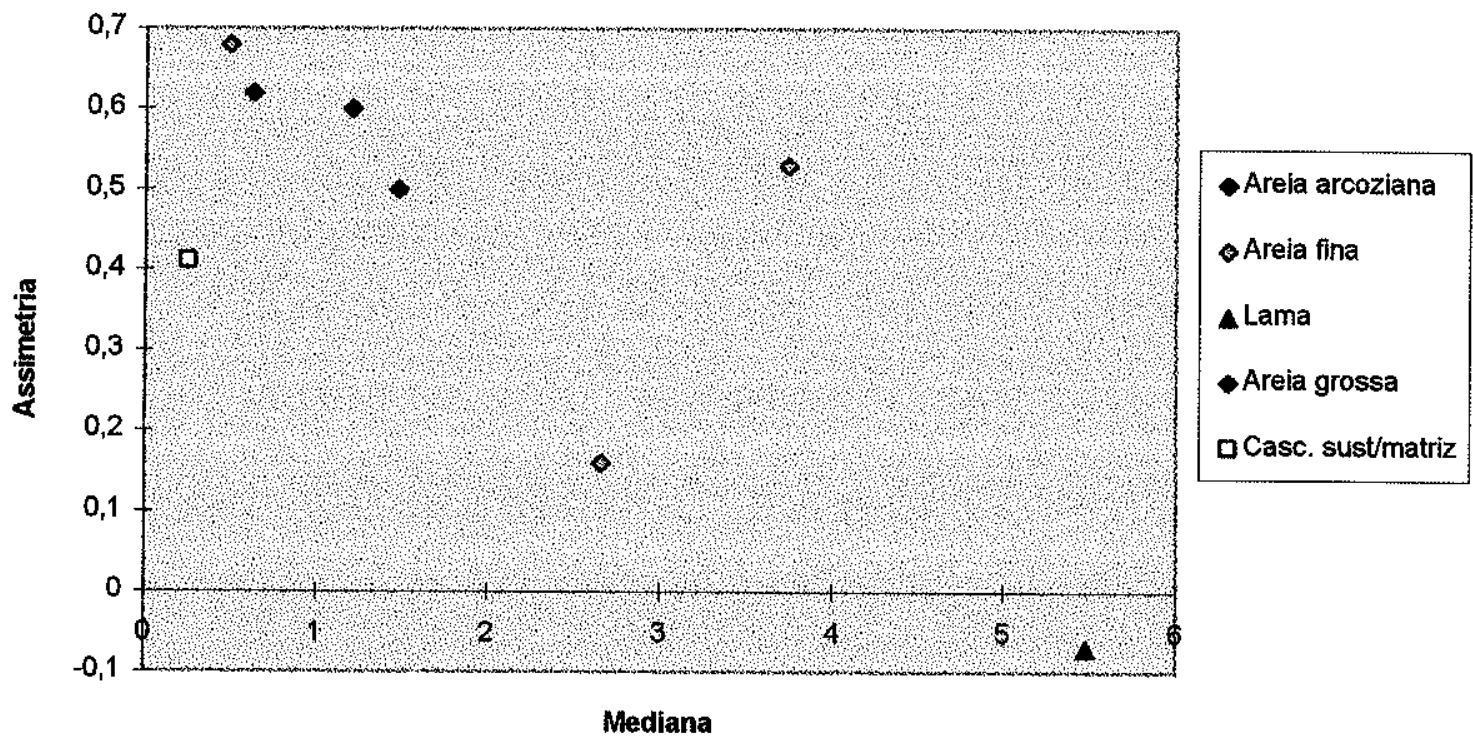

Figura 64: Parâmetros estatísticos médios de Folk \& Ward (1957) do leque aluvial Cubatão para mediana $x$ assimetria (valores em $\phi$ )

No caso do leque aluvial Cubatão, as amostras da Fig. 63 concentram-se em população com valores mais baixos de diâmetro médio e mediana, onde dominam as areias. Entretanto, na Fig. 64 esta mesma população apresenta valores altos de assimetria e valores baixos de mediana

No leque aluvial Morretes não foi possível obter amostras representativas. 
Os gráficos contendo todas as amostras dos leques aluviais (Figs. 65 e 66), mostram as mesmas tendências observadas nos gráficos por leques individuais apresentados anteriormente, principalmente no que se refere a relação entre o diâmetro médio e mediana (Fig. 65).

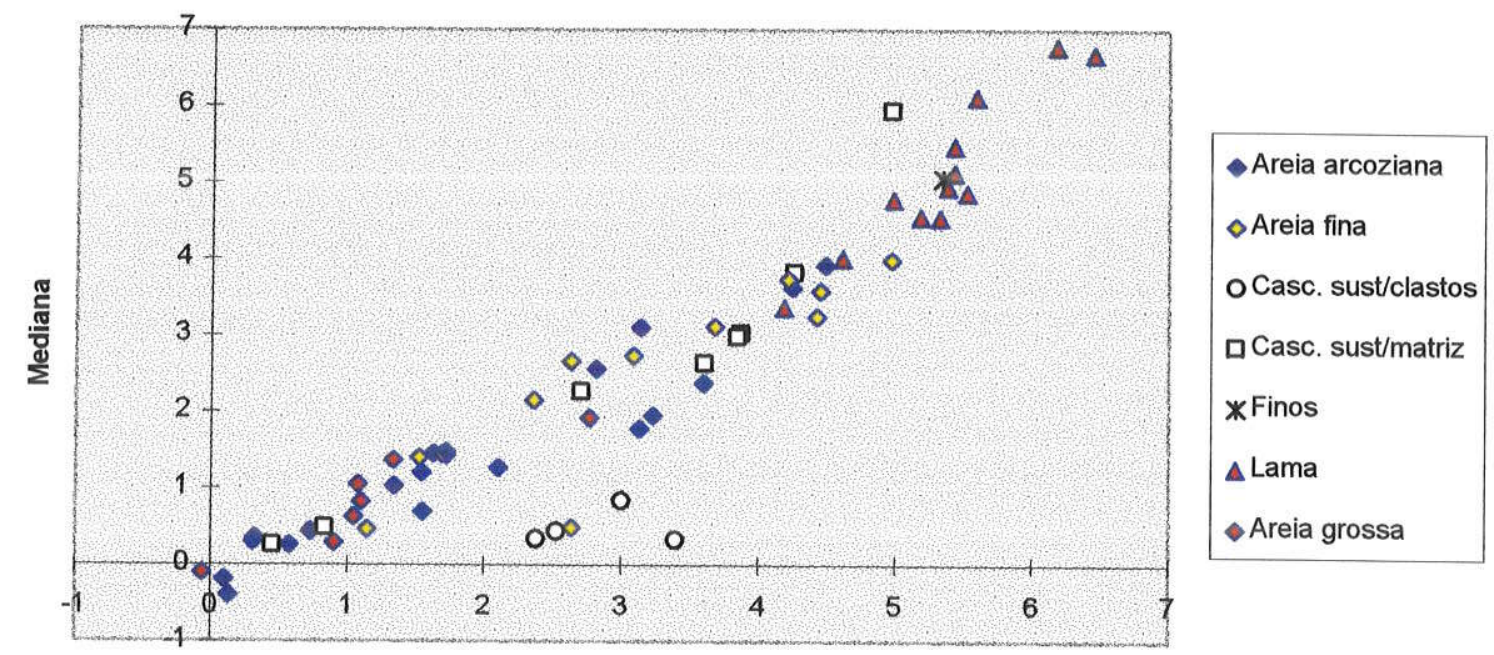

Diâmetro Médio

Figura 65: Parâmetros estatísticos médios de Folk \& Ward (1957) dos leques aluviais para diâmetro médlio $\mathrm{x}$ mediana (valores em $\phi$ )

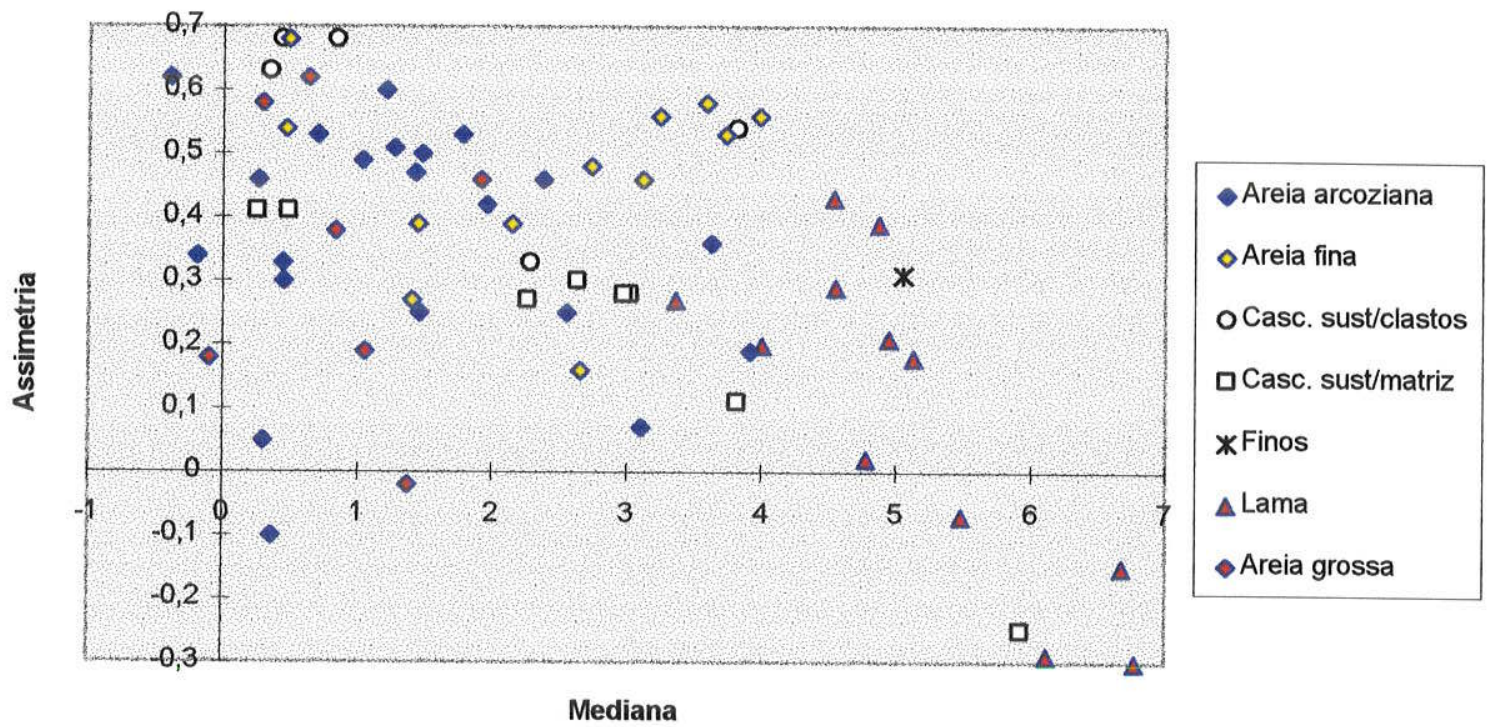

Figura 66: Parâmetros estatísticos médios de Folk \& Ward (1957) dos leques aluviais para mediana $x$ assimetria (valores em $\phi$ ) 
No caso do gráfico de relação mediana $\mathrm{x}$ assimetria (Fig. 66) para todas as amostras dos leques aluviais, os pontos mostram-se bastante dispersos, não podendo ser feita uma melhor avaliação sobre as populações de amostras.

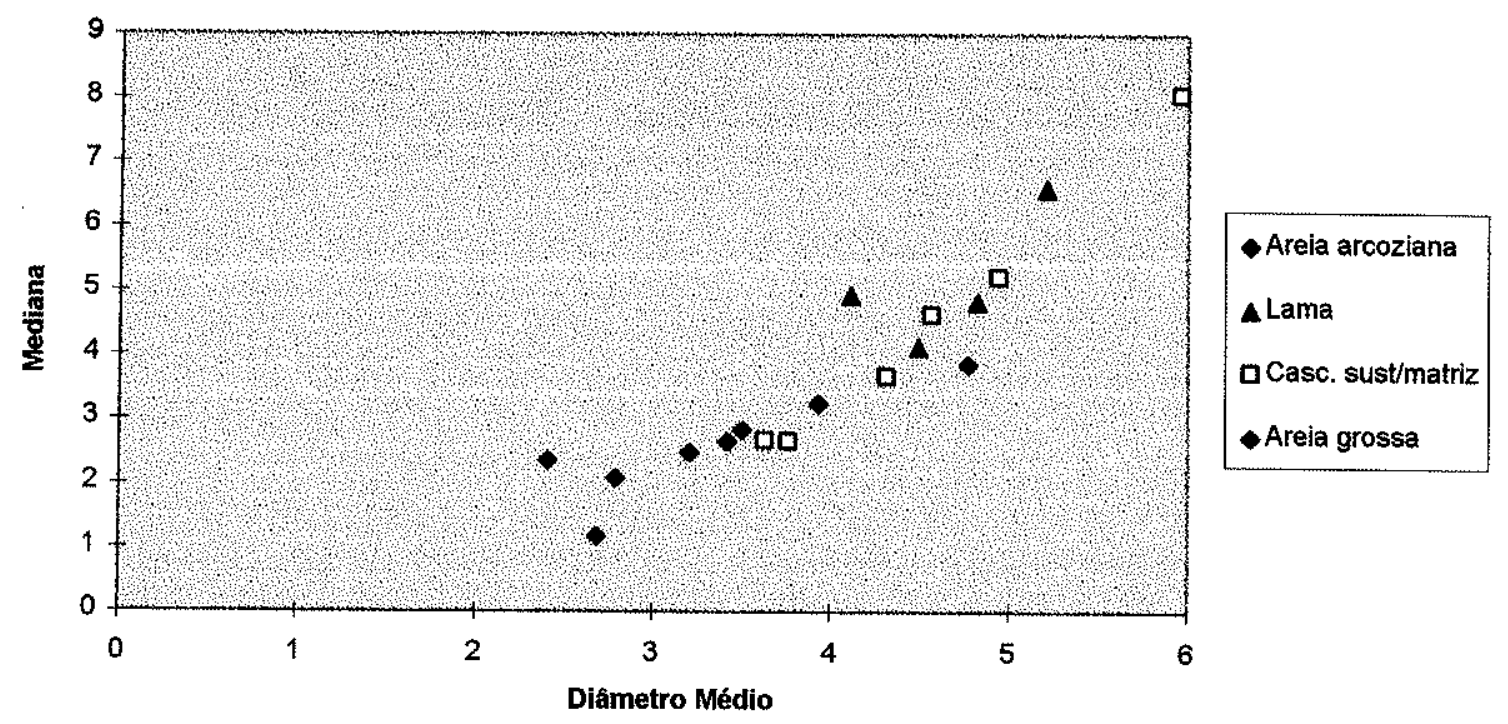

Figura 67: Parâmetros estatísticos médios de Folk \& Ward (1957) dos leques aluviais Brejatuba, Pombas, Caovi e Miranda para diâmetro médio $x$ mediana (valores em $\phi$ )

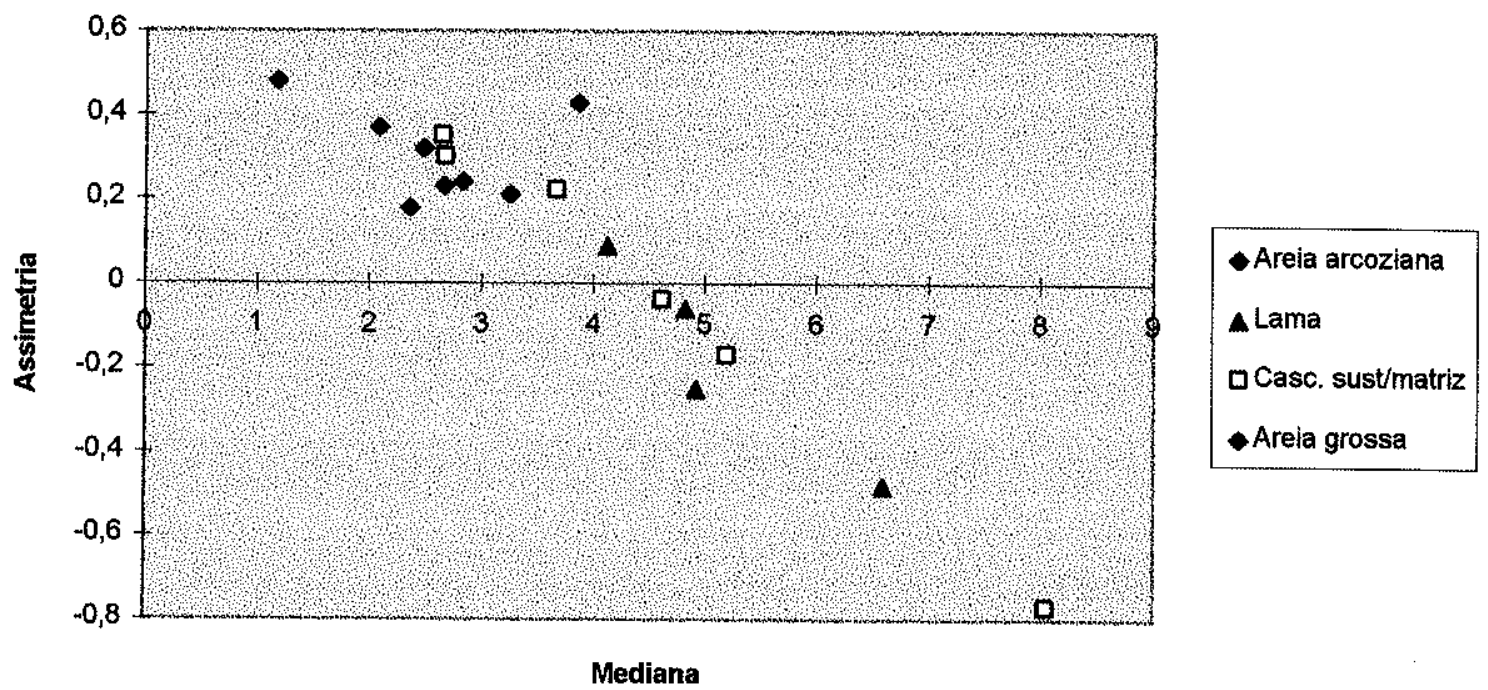

Figura 68: Parâmetros estatísticos médios de Folk \& Ward (1957) dos leques aluviais Brejatuba, Pombas, Caovi e Miranda para mediana $x$ assimetria (valores em $\phi$ ) 
Devido às características sedimentares e geomórficas distintas já mencionadas no item 6.4.1, os parâmetros estatísticos médios de Folk \& Ward (1957) dos leques aluviais Brejatuba, Pombas, Caovi e Miranda, foram relacionadas em gráficos separados (Figs. 67 e 68).

No caso do gráfico diâmetro médio $\mathrm{x}$ mediana (Fig. 67), apesar de não tão bem definida a tendência de distribuição das amostras é semelhante ao comportamento das amostras dos outros leques aluviais. Entretanto, o mesmo não ocorre para o gráfico de mediana $x$ assimetria (Fig. 68), que apresentou certa concentração de amostras de sedimentos mais arenosos com comportamento diferente dos outros leques aluviais. 


\subsubsection{Diagramas CM}

Os diagramas seguintes mostram possíveis relações entre a textura de sedimentos e os processos de sedimentação envolvidos nos depósitos das unidades aqui estudadas.

No diagrama de barra da Fig. 69, estão representadas as distribuições dos valores médios de $\mathrm{C}$ e $\mathrm{M}$ para esses unidades estratigráficas. Ressalta-se neste diagrama o comportamento do leque aluvial Cubatão que apresenta baixos valores de C, devido provavelmente a suas características fluviais arenosas de melhor seleção.

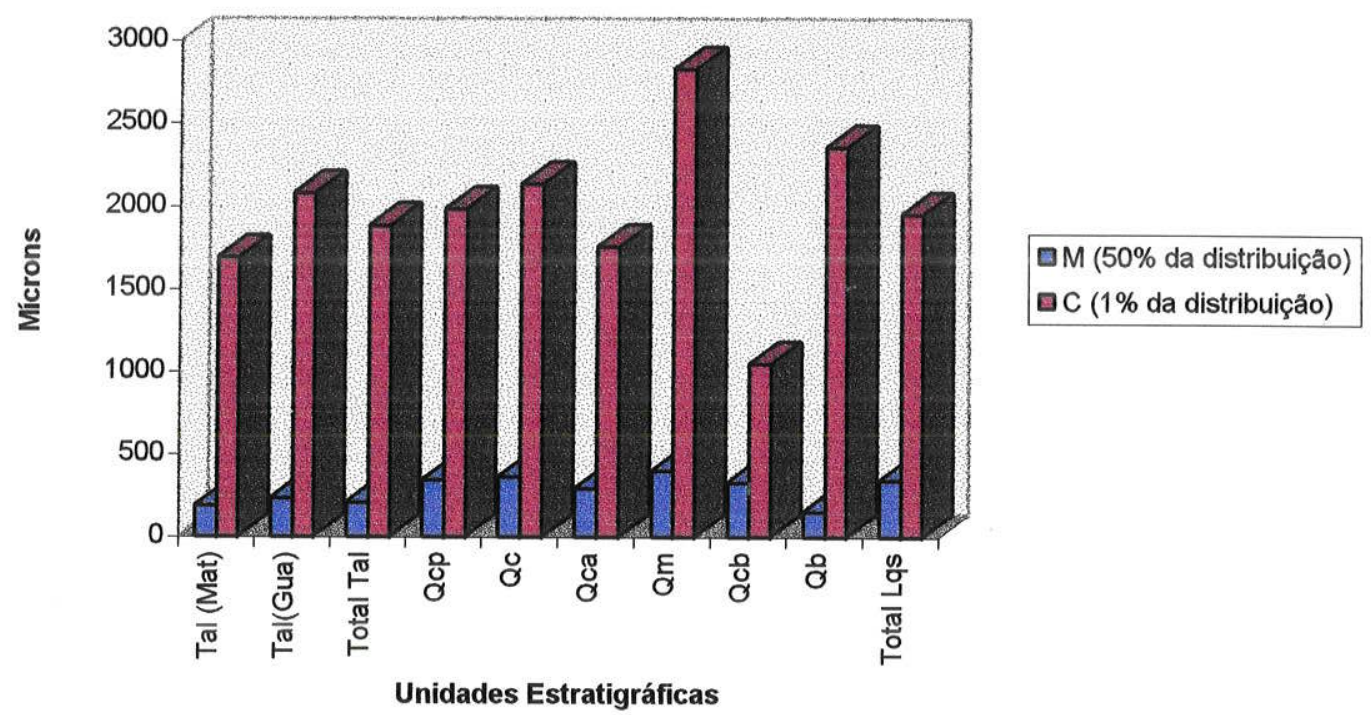

Figura 69: Valores Médios de CM (Passega, 1957) por Unidade Estratigráfica

Nos diagramas CM (Passega, 1957), o C (granulometria correspondente a $1 \%$ da distribuição) é usado no eixo y e o $\mathrm{M}$ (granulometria correspondente a $50 \%$ da distribuição) no eixo x. Segundo Bull (1972), estes parâmetros relacionam-se à competência e à turbulência dos agentes de deposição.

$\mathrm{Na}$ concepção destes diagramas, Passega (1957) utilizou principalmente amostras de sedimentos marinhos e fluviais para que pudesse determinar padrões no gráfico que indicassem os processos envolvidos na sedimentação. Entretanto, Bull (1962 e 1972) utilizou-se destes diagramas para representar os processos de 
sedimentação em leques aluviais, achando padrões bastante característicos para estes sistemas deposicionais. O padrão encontrado por Passega (1957) para correntes de turbidez coincide com o de Bull (1972) para processos de fluxos de lama, mas o mesmo não ocorre com o padrão para correntes de tração que são muito diferentes entre estes autores.

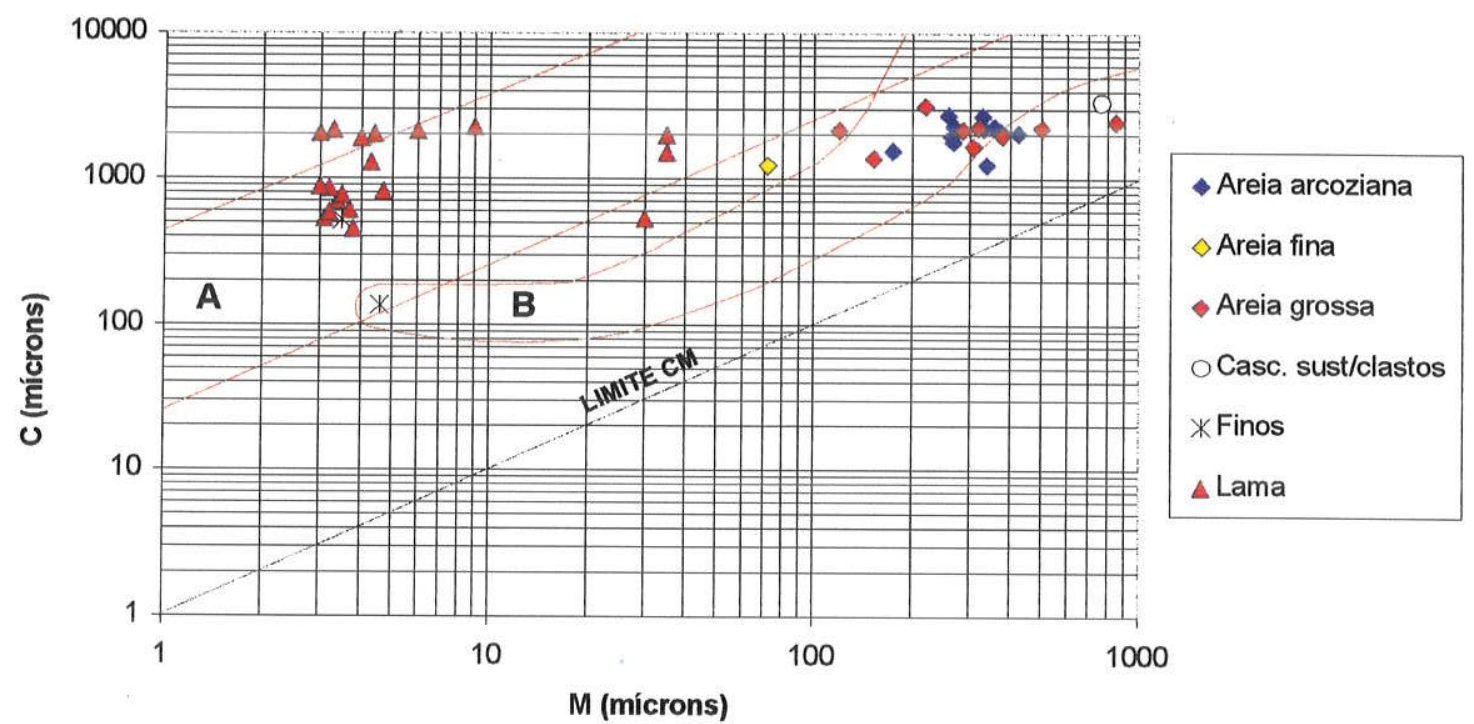

Figura 70: Diagrama CM (Passega, 1957) para sedimentos da Formação Alexandra na região de Alexandra (A = fluxos de lama; $B$ = sistema fluvial entrelaçado).

Para este trabalho optou-se pelos padrões encontrados por Bull (1972), por terem melhor se adequado aos depósitos aqui estudados.

No diagramas CM para a Formação Alexandra (região de Alexandra), que se encontra na Fig. 70, pode-se notar como os padrões propostos por Bull (1972) são bastante adequados para as fácies desta formação. Uma fácies de fluxos densos, composta quase que exclusivamente de lamas, caracteriza corridas de lama (mudflow), enquanto que a fácies fluvial, composta de areias, caracteriza rios entrelaçados (braided).

Tal como nos diagramas de dispersão dos parâmetros estatísticos de Folk \& Ward (1954), os diagramas CM também apresentam amostras com características intermediárias, que podem ter recebido influências tanto dos processos de corridas de lama como de rios entrelaçados, ou ainda, ter sofrido intemperismo que modificou 
suas características originais, como se verifica nas alterações dos grãos de feldspatos encontrados em muitas amostras.

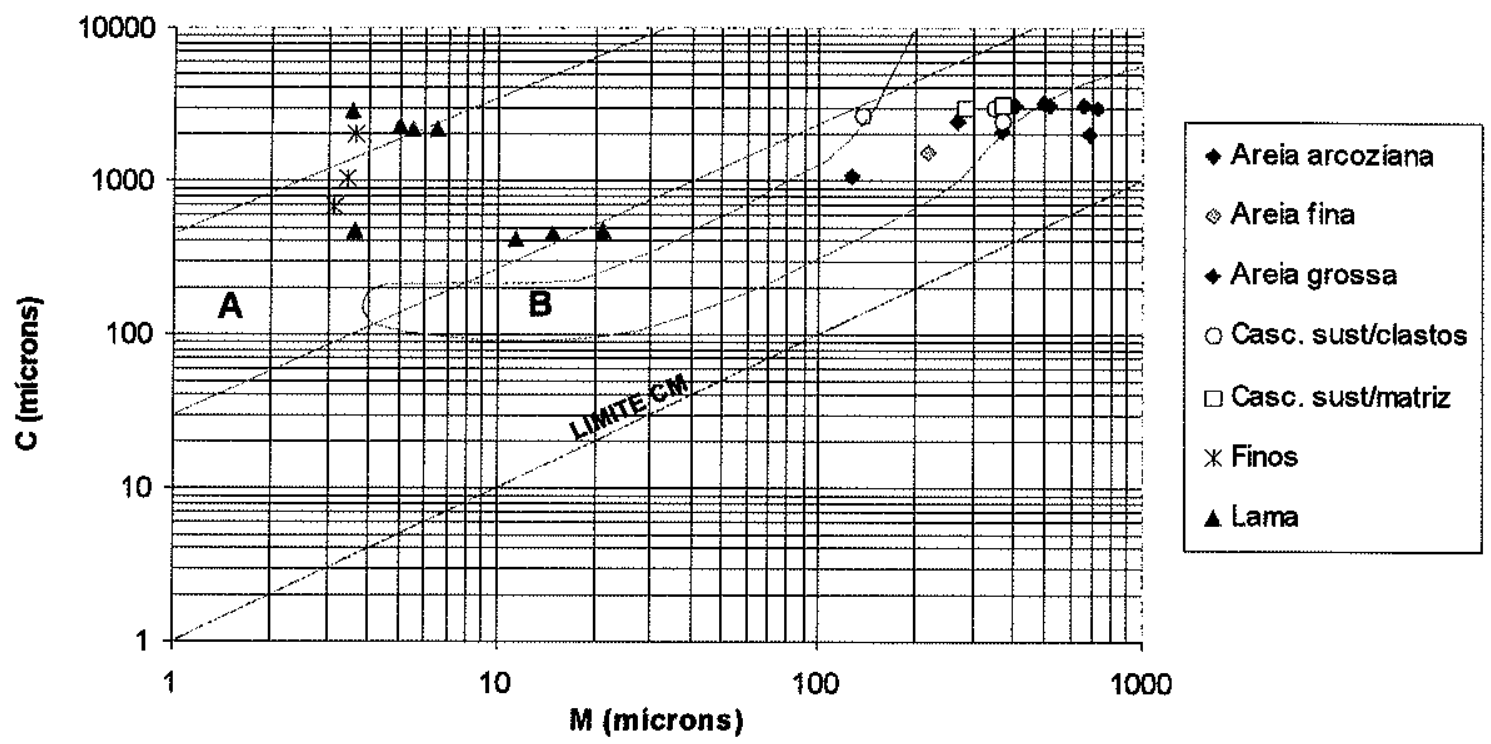

Figura 71: Diagrama CM (Passega, 1957) para sedimentos da Formação Alexandra na entrelaçado) região de Guaraqueçaba $(A=$ fluxos de lama; $B=$ sistema fluvial

O diagrama CM da Formação Alexandra para a região de Guaraqueçaba (Fig. 71) apresenta amostras com comportamentos semelhantes aos encontrados para a região de Alexandra, inclusive amostras de características intermediárias. Apesar da grande similaridade entre os dois gráficos, deve-se ressaltar neste último uma granulometria mais grossa.

No diagrama de todas as amostras (Fig. 72) é mais evidente a similaridade entre os dois gráficos, mostrando que a características dos ambientes de deposição foram semelhantes. 


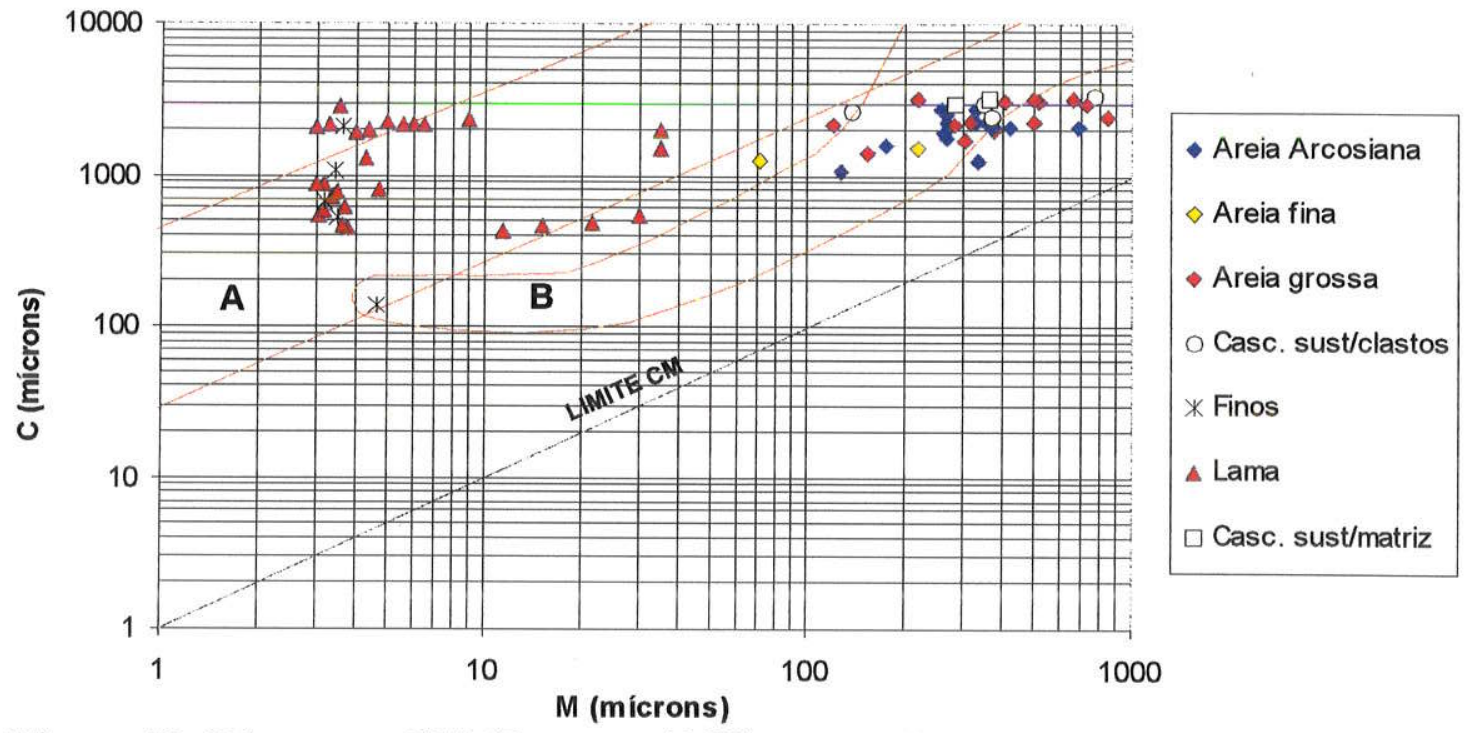

Figura 72: Diagrama CM (Passega, 1957) para todas as amostras da Formação Alexandra ( $A=$ fluxos de lama; $B=$ sistema fluvial entrelaçado).

No leque aluvial Colônia Pereira, apesar da presença de muitos lamas características de fluxos de lama (Fig. 73), verifica-se o predomínio maior de amostras de areias de ambientes fluviais.

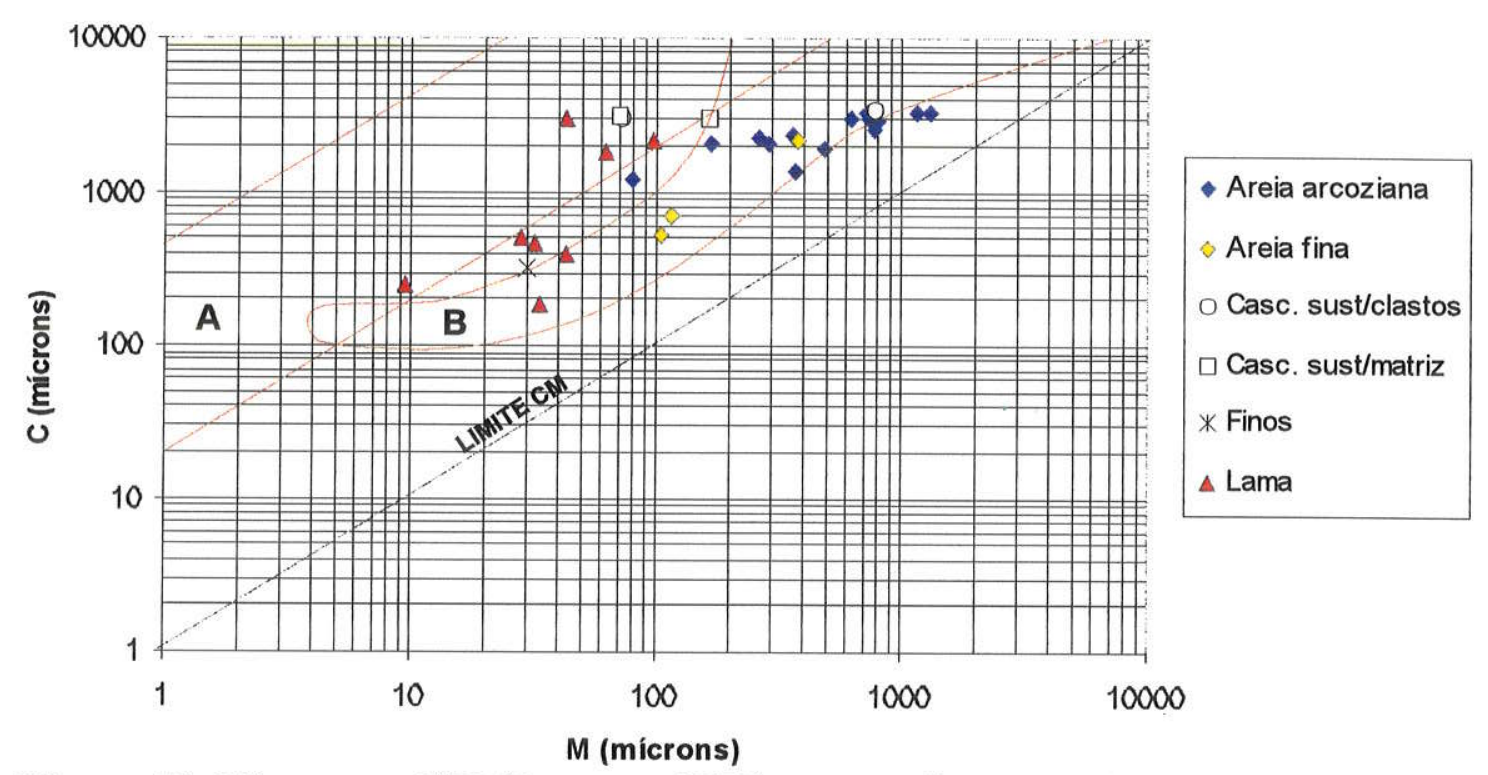

Figura 73: Diagrama CM (Passega, 1957) para sedimentos do leque aluvial Colônia Pereira ( $A=$ fluxos de lama; $B=$ sistema fluvial entrelaçado).

A tendência observada no leque aluvial Colônia Pereira é também encontrada nos outros leques (Figs. 74, 75, 76 e 77), mostrando que na origem dos 
leques aluviais houve o predomínio de processos fluviais com rios entrelaçados. Esta tendência é mais evidente quando se observa o gráfico de todas as amostras de leques aluviais (Fig. 78).

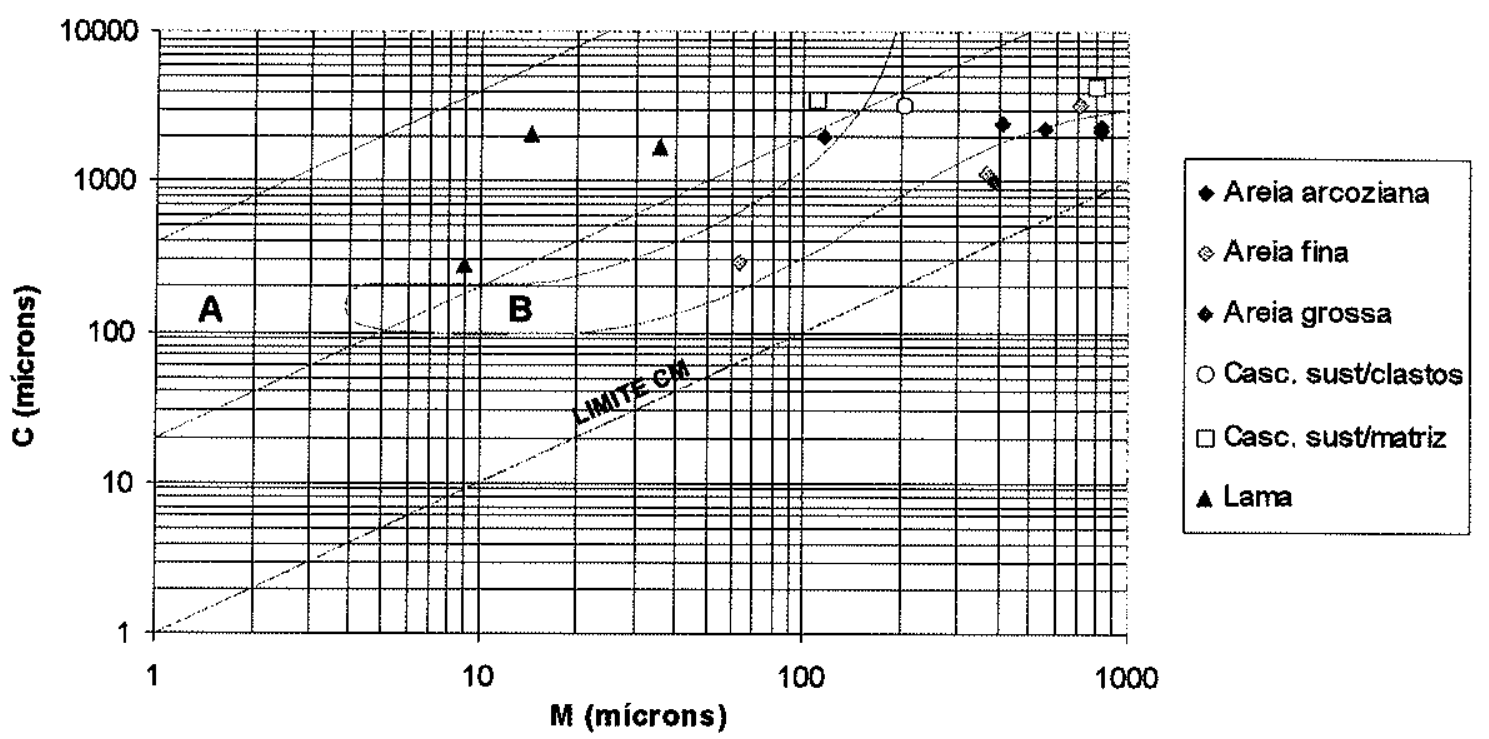

Figura 74: Diagrama CM (Passega, 1957) para sedimentos do leque aluvial Cambará ( $A$ = fluxos de lama; $B=$ sistema fluvial entrelaçado).

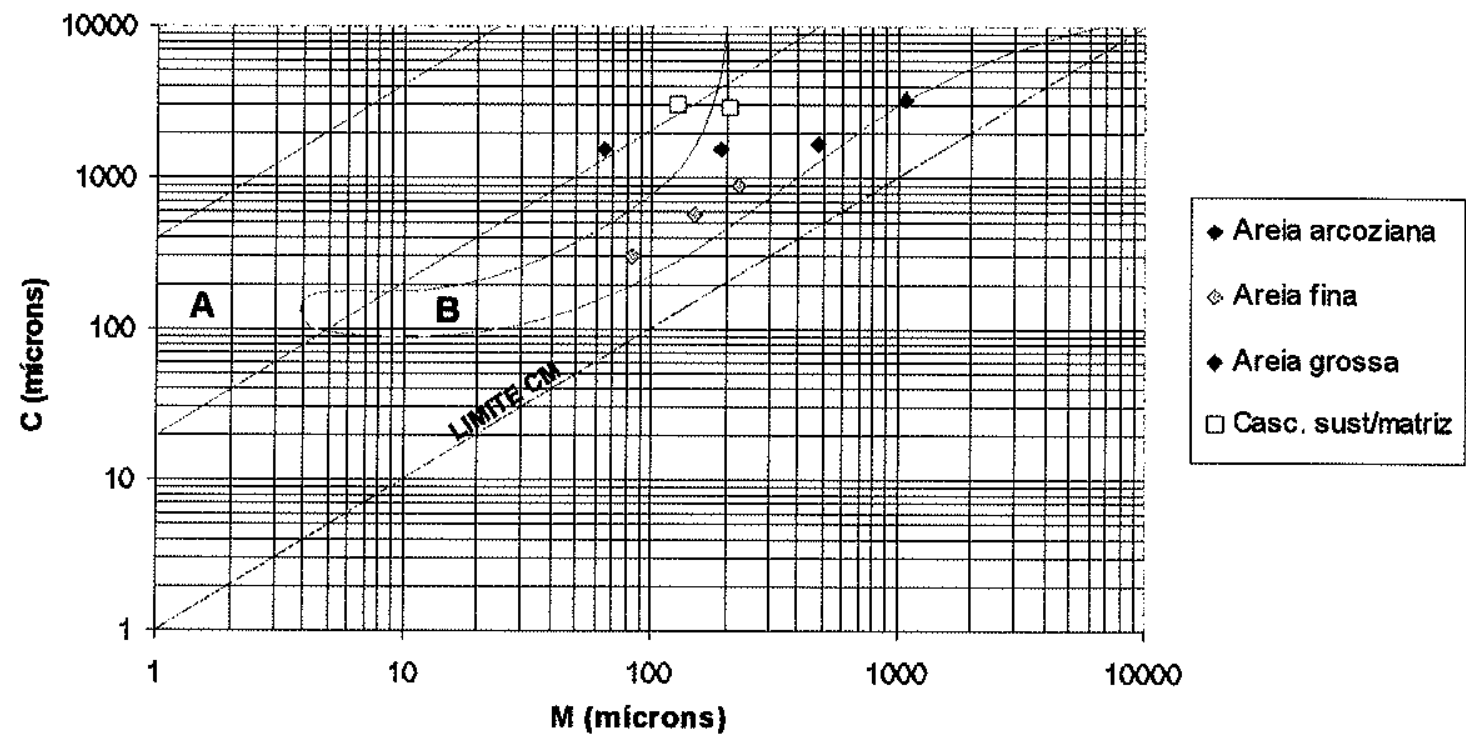

Figura 75: Diagrama CM (Passega, 1957) para sedimentos do leque aluvial Cachoeirinha $(A=$ fluxos de lama; $B=$ sistema fluvial entrelaçado). 


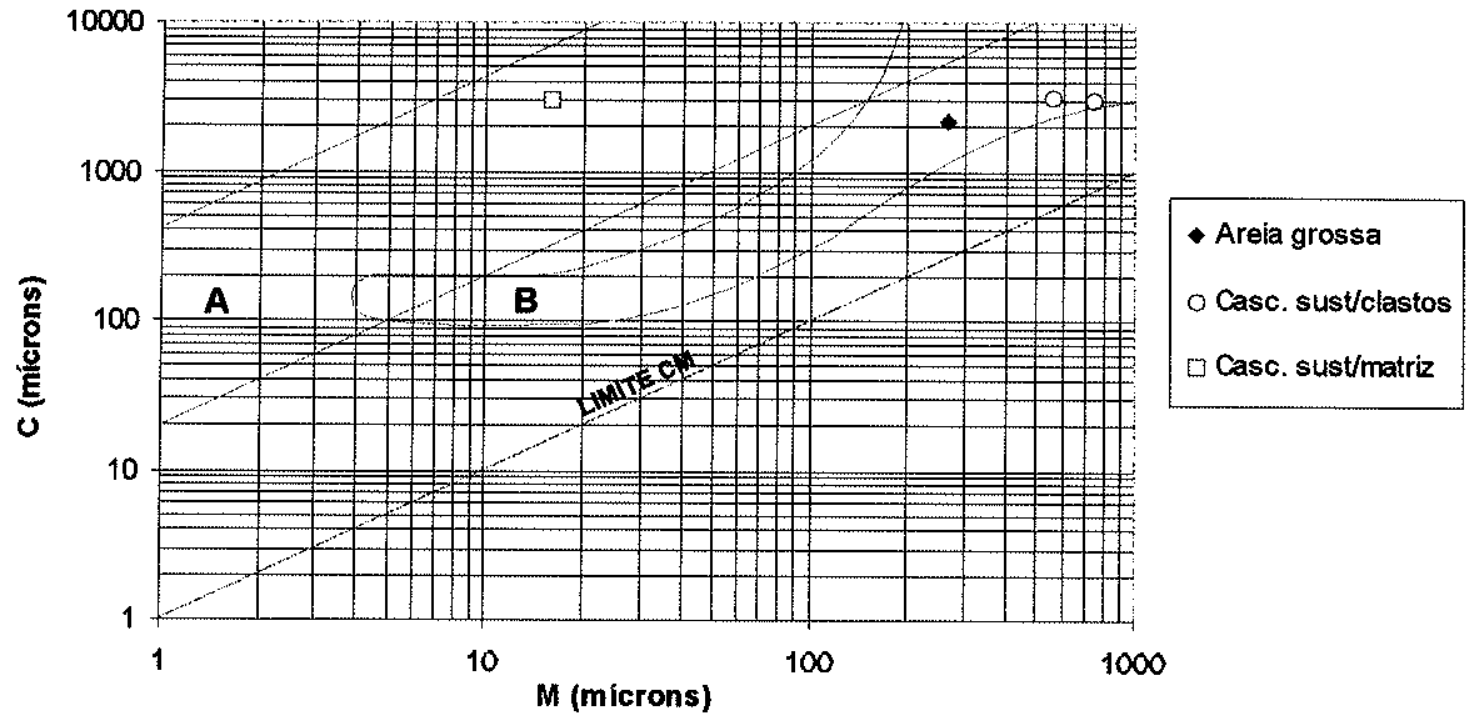

Figura 76: Diagrama CM (Passega, 1957) para sedimentos do leque aluvial Morretes ( $A$ = fluxos de lama; $B$ = sistema fluvial entrelacado).

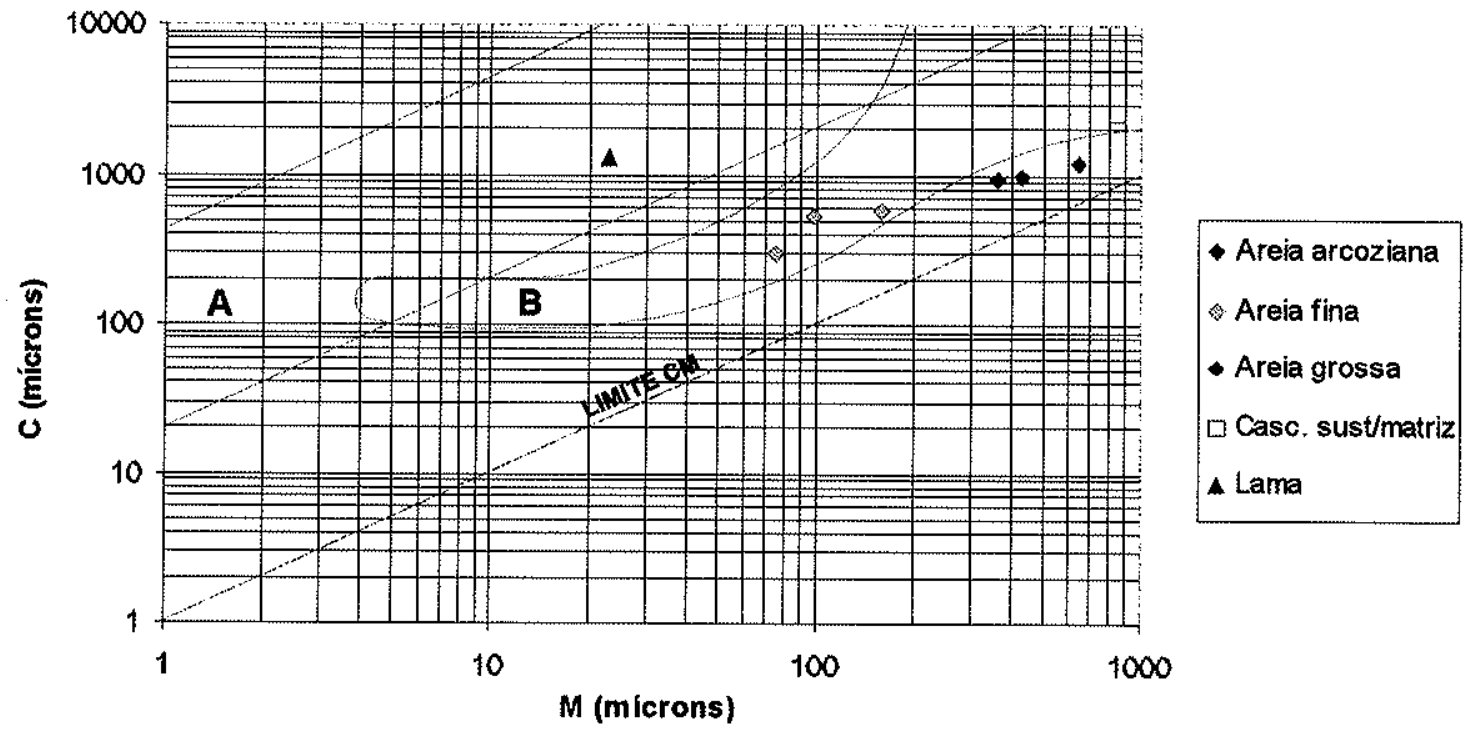

Figura 77: Diagrama CM (Passega, 1957) para sedimentos do leque aluvial Cubatão ( $A$ = fluxos de lama; sistema fluvial entrelaçado). 


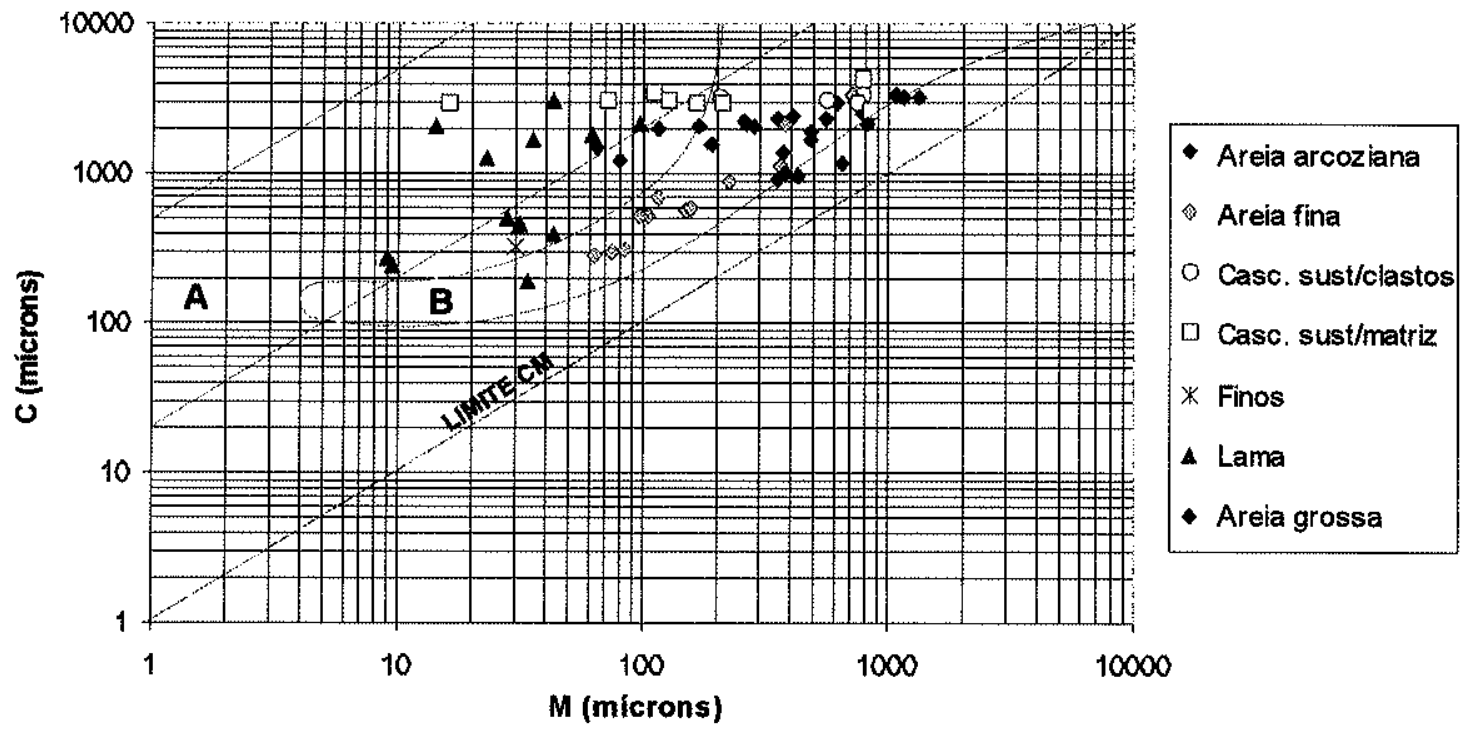

Figura 78: Diagrama CM (Passega, 1957) para sedimentos de todos os leques luviais ( $A$ = fluxos de lama; $B$ = sistema fluvial entrelaçado)

Da mesma forma que para os parâmetros de Folk \& Ward (1954), as amostras dos leques aluviais Brejatuba, Pombas, Caovi e Miranda são apresentadas em gráfico CM separado (Fig, 79), por mostrarem características sedimentológicas distintas dos outros leques aluviais.

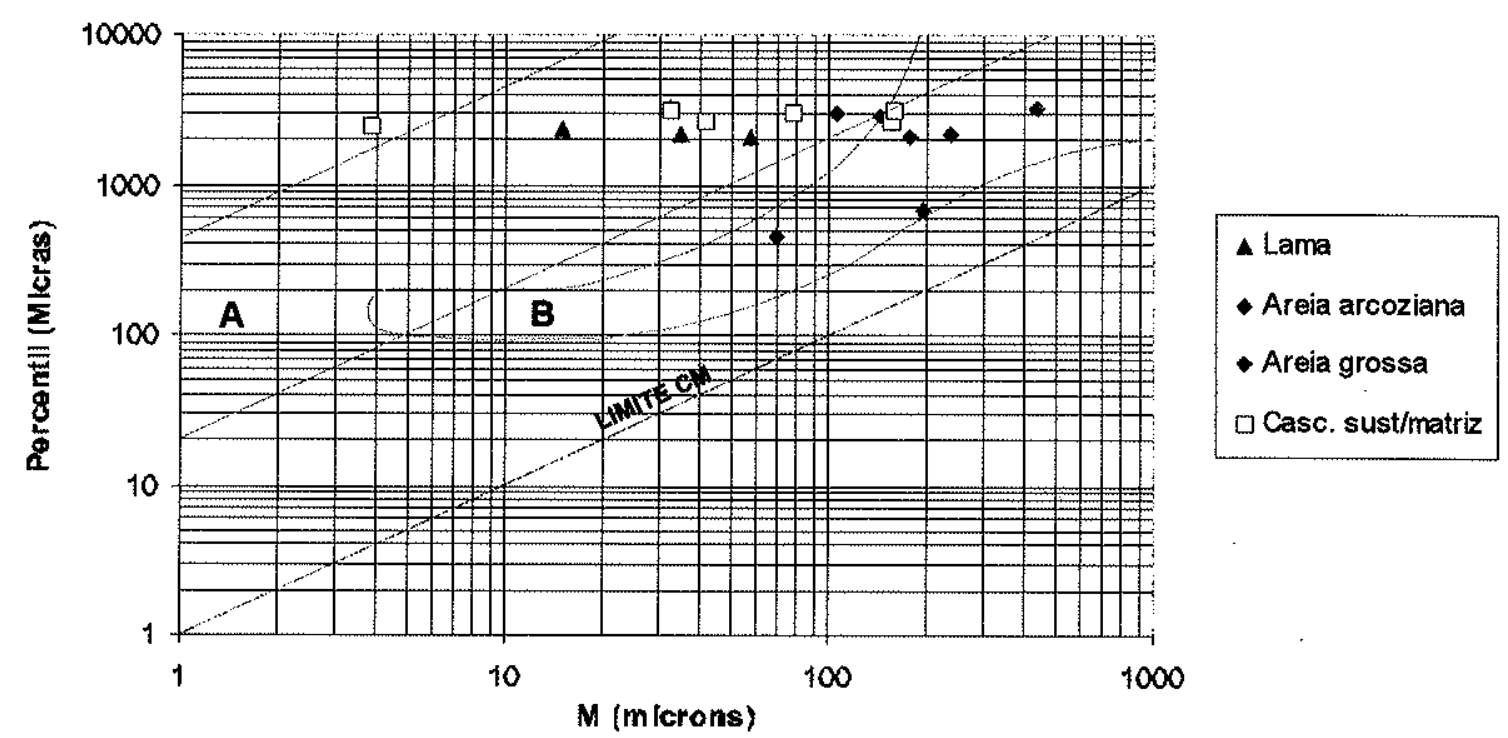

Figura 79: Diagrama CM (Passega, 1957) para sedimentos dos leques aluviais Brejatuba, Pombas, Caovi e Miranda ( $A=$ fluxos de lama; $B=$ sistema fluvial entrelaçado). 
Como se verifica na Fig. 79, esses leques aluviais apresentam poucas amostras com padrão de rios entrelaçados e predomínio de amostras em padrão de corridas de lama, diferenciando-se dos outros leques aluviais que apresentam a maioria das amostras em padrões de processos fluviais. Isto é corroborado pelo fato dos leques aluviais Brejatuba, Pombas, Caovi e Miranda apresentarem amostras bem mais imaturas que os outros leques, tal como verificado para os parâmetros de Folk \& Ward (1954) (item 6.4.1.1). 


\subsubsection{Minerais Pesados}

$\mathrm{O}$ resultado com análise dos minerais pesados mostra que em todas as unidades os minerais opacos predominam sobre os minerais transparentes (Fig. 80).

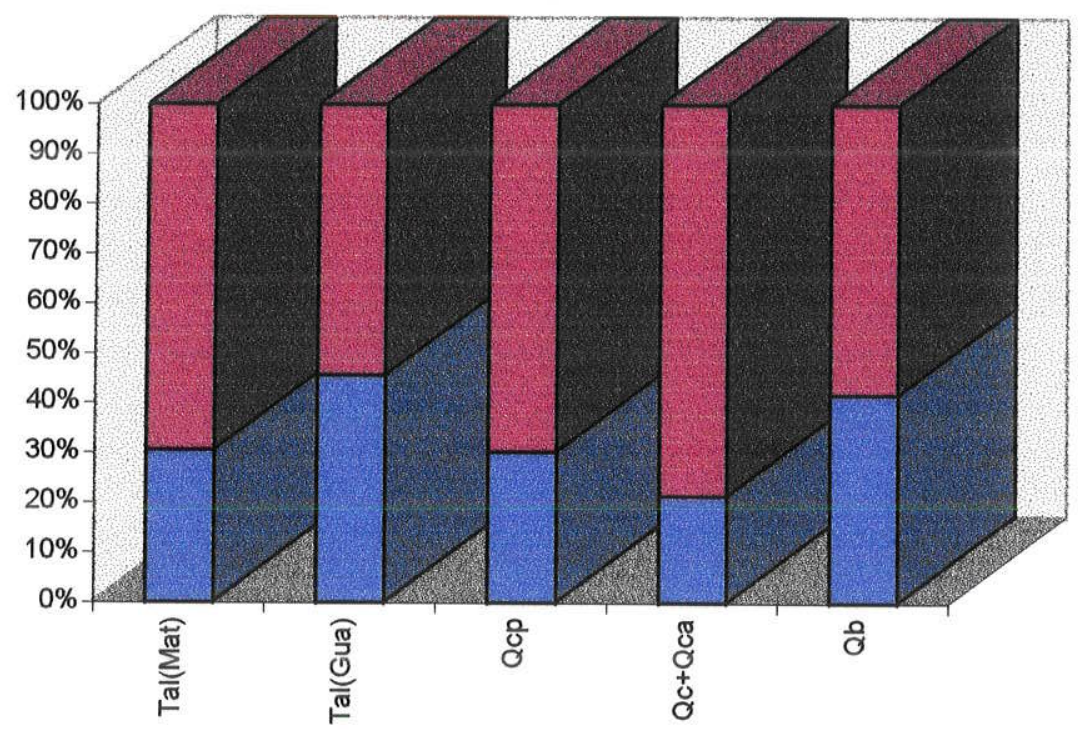

Figura 80: Porcentagens médias de ocorrência dos minerais pesados opacos e transparentes por unidades estratigráficas

Os valores médios, por unidades estratigráficas, dos índices ZTR e dos minerais estáveis, moderadamente estáveis, instáveis e alteritos, encontram-se na Fig. 81. Os maiores índices ZTR são do leque aluvial Colônia Pereira e os menores índices são do leque aluvial Brejatuba e da Formação Alexandra. Esta similaridade entre a Formação Alexandra e o leque aluvial Brejatuba já foi observada no item 6.4.1 (Figs. 51 e 52). Entretanto, a maior variação entre tipos de minerais pesados transparentes que ocorre na Formação Alexandra, sugere que esta unidade teve áreas-fontes distintas das outras unidades estudadas. A maior frequência de minerais instáveis está relacionada aos depósitos mais imaturos desta unidade (lamas e cascalhos sustentados por matriz) que representam as fácies de fluxos densos. 


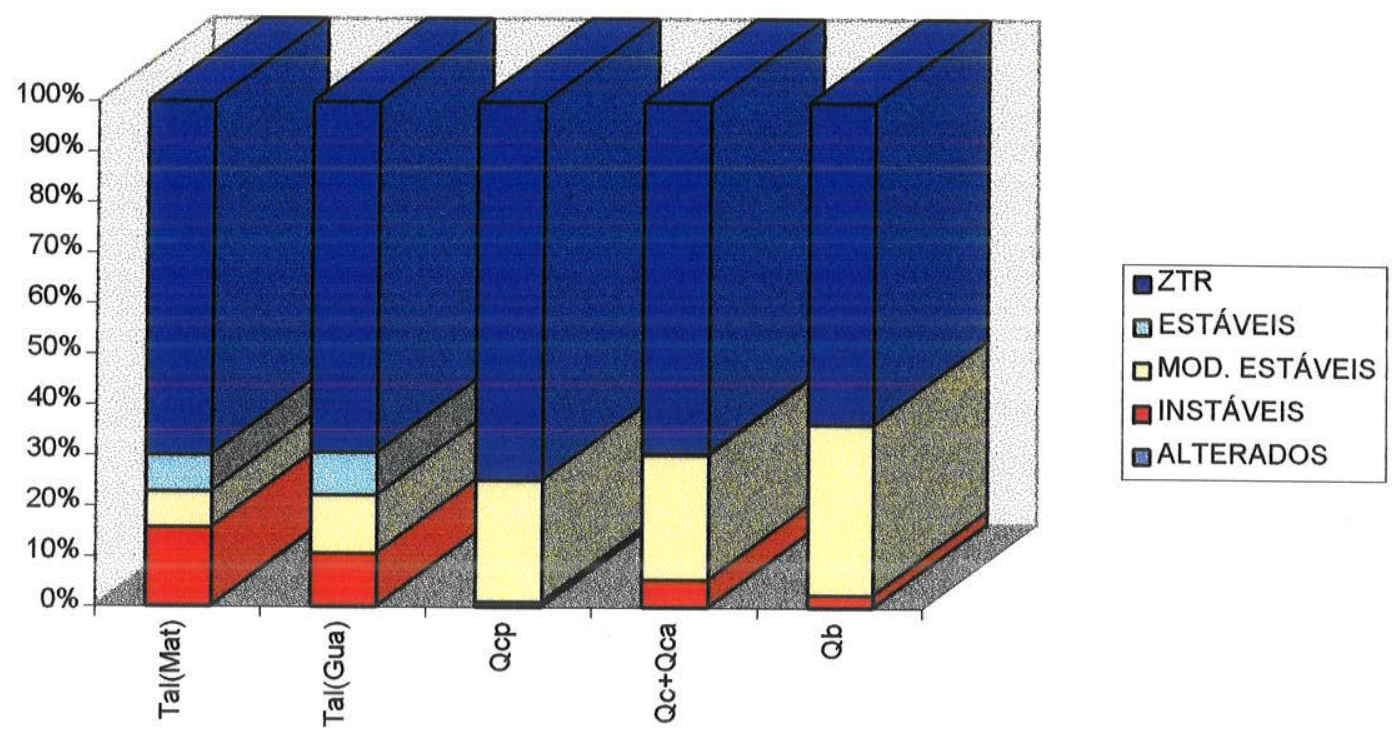

Figura 81: Porcentagens médias dos tipos de minerais pesados transparentes por unidades estratigráficas.

A Fig. 82 mostra as porcentagens médias relativas de todos os minerais pesados transparentes identificados por unidade estratigráfica. A maior frequência de turmalina e zircão em todas as unidades pode estar associada, tanto à alta estabilidade desses minerais quanto ao fato de serem minerais bastante comuns no embasamento cristalino. Com exceção dos leques aluviais Cambará-Cachoeira, todas as unidades estudadas apresentaram quantidades maiores de turmalina que zircão que, segundo Mange \& Maurer (1992), poderiam indicar ambientes de alta energia de transporte como rios entrelaçados (braided). Isto é verificado na Formação Alexandra, também pela presença de estaurolita e sillimanita. No entanto, os afloramentos da Formação Alexandra que se encontram na região de Alexandra (Tal-Mat), o hiperstênio é bastante frequente como mineral pesado instável em algumas amostras de lamas, levando a supor que nesses sedimentos o transporte foi pouco eficiente, estando relacionado a fluxos densos (Pettijohn, 1975). A estaurolita encontrada na Formação Alexandra exibiu dissolução intraestratal, que pode ter ocorrido durante processos intempéricos. Esses processos devem ter sido influenciados pelo clima muito úmido da região do litoral paranaense. Segundo Mange \& Maurer (1992), algumas assembléias de minerais pesados se relacionam à ambientes ácidos, típicos de climas 
tropicais úmidos e com muita laterização, tais como os níveis de laterita que foram encontrados em afloramentos da Formação Alexandra na região de Alexandra, próximos à seção-tipo. Neste caso, o processo de laterização pode ser uma resposta ao intemperismo que foram submetidos os depósitos da Formação Alexandra.

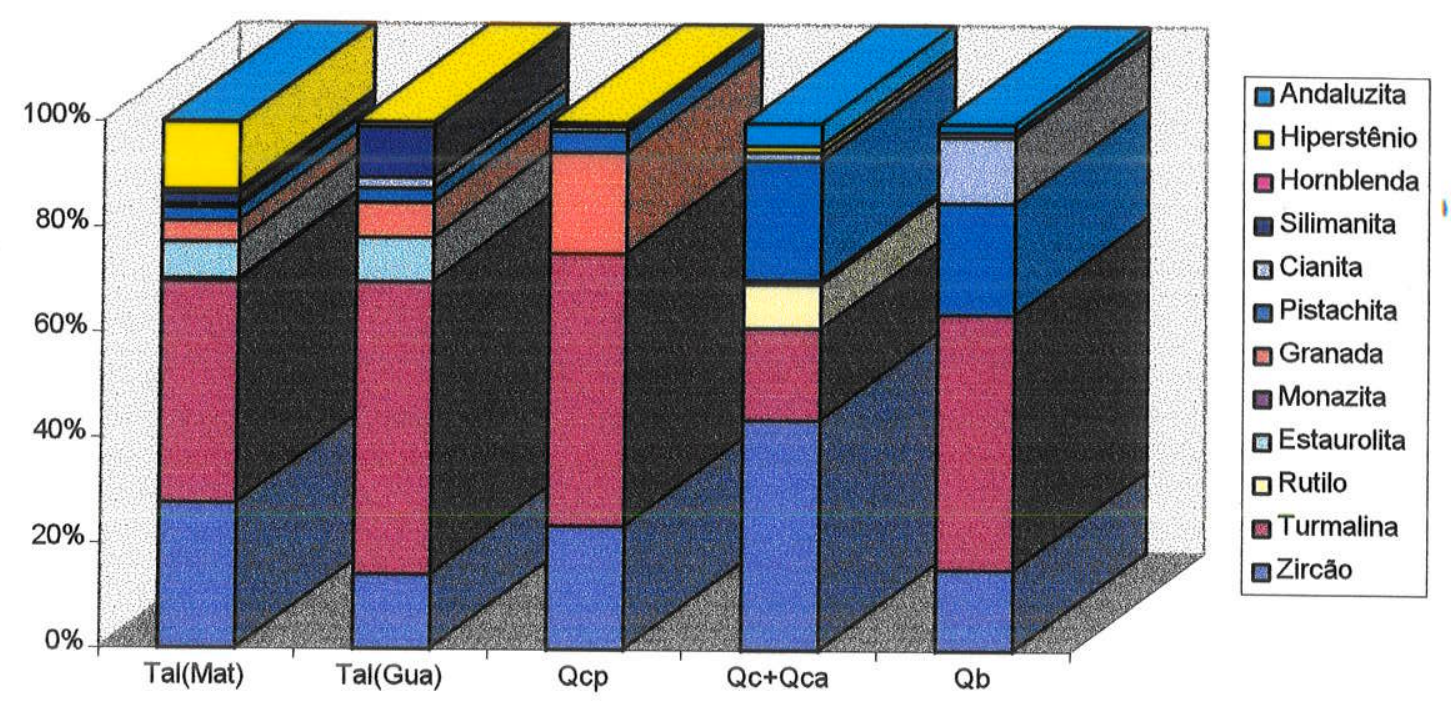

Figura 82: Frequiências médias de ocorrência dos minerais pesados transparentes por unidades estratigráficas.

O leque luvial Cambará-Cachoeira apresenta quantidades maiores de zircão do que turmalina, contendo também a presença de rutilo (Fig. 82) que segundo Mange \& Maurer (1992), poderiam indicar ambientes com mais baixas energias de transporte, mas ainda relacionados aos ambientes de rios entrelaçados.

Todas as unidades apresentadas possuem índice ZTR sempre acima de $60 \%$ (Fig. 81), indicando alto grau de maturidade desses depósitos. No entanto, a presença de minerais instáveis ou moderadamente estáveis, juntamente com dissoluções intraestratais na estaurolita, sugerem desaparecimento de minerais mais instáveis ao ambiente em que foram depositados os sedimentos mais imaturos, como as lamas e os cascalhos sustentados por matriz. Deve-se também considerar a possibilidade de ausência de alguns minerais pesados instáveis na área-fonte. 
Com resultados diferentes, a análise de minerais pesados realizada por Melo (1990) para a Formação Pariqüera-Açu mostrou que os minerais transparentes sempre ocorrem em maior proporção que os minerais opacos. $\mathrm{O}$ autor argumenta que em unidades onde os minerais opacos ocorrem em quantidades mais expressivas poderia ser um reflexo da razão hidráulica, relacionada aos depósitos mais grossos e mal selecionados. Para a Formação Alexandra não se poderia fazer esta relação, já que os resultados entre minerais transparentes e opacos é bastante discrepante quanto aos resultados encontrados por Melo ( $c p$. cit.), mas ressalta-se a intensa decomposição química que sofreram esses depósitos, podendo ter havido dissolução de parte dos minerais pesados transparentes originais, mudando assim as características mineralógicas e químicas dos depósitos estudados.

\subsubsection{Minerais de Argila}

Para este trabalho de dissertação, foram coletadas oito amostras de argilas de novos afloramentos dessa formação e catorze amostras de leques aluviais quaternários, que foram selecionados pelo método de Capacidade de Troca de Cátions (CTC). Por este método, apenas duas amostras se mostraram adequadas para o método de análise termodiferencial, que indicou a caulinita como o mineral de argila predominante. As outras amostras, já no teste de seleção com azul de metileno, mostraram a presença da caulinita.

Os gráficos das Figs. 83 e 84 mostram o comportamento das argilas de leques aluviais quaternários quando colocadas em altas temperaturas no equipamento de ATD. A linha que sobe linearmente indica a elevação da temperatura que estas amostras foram submetidas. A presença da caulinita é indicada pelo pico maior invertido nos dois gráficos. O pico menor invertido do gráfico da Fig. 84 indica a existência de gibsita livre - $\mathrm{Al}(\mathrm{OH})_{3}$, sugerindo a ocorrência de intemperismo prolongado com intensas lixiviações após a deposição e que são comuns sob climas subtropicais a tropicais (Dana, 1976). 


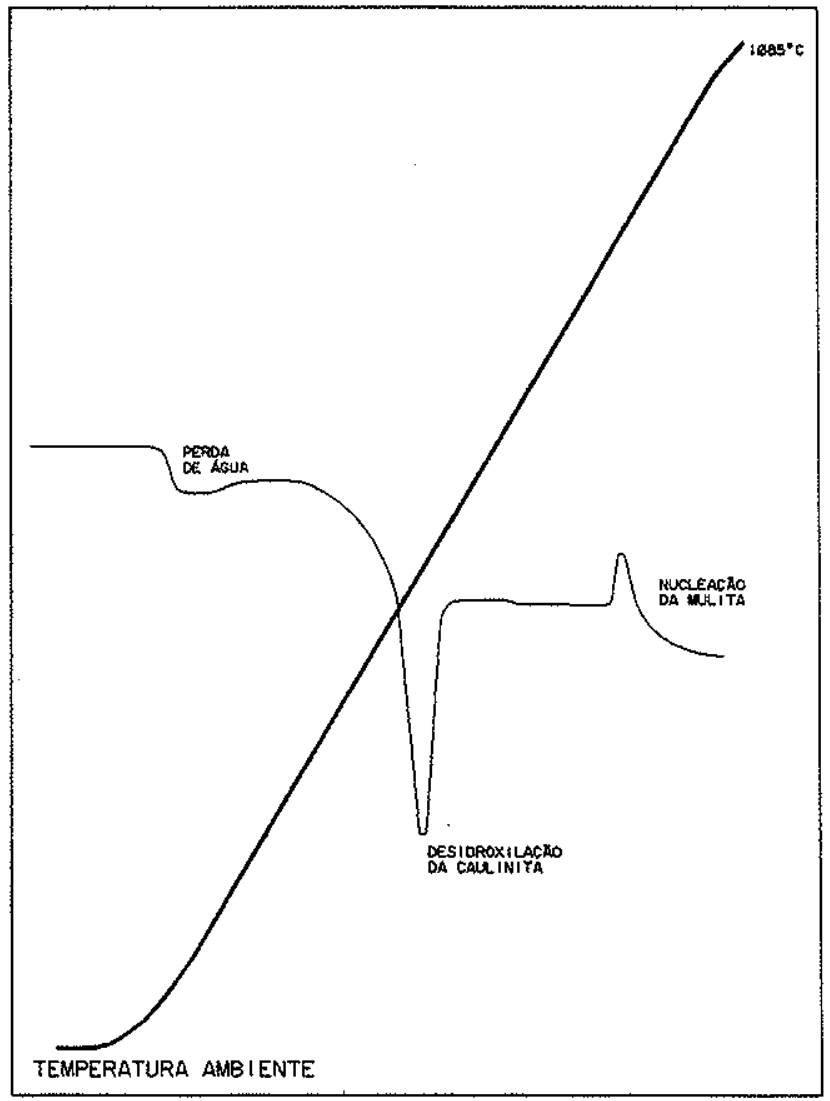

Figura 83: Gráfico de ATD mostrando o comportamento da argila da amostra do ponto 20.2.92-05 do leque aluvial Morretes quando submetida à altas temperaturas.

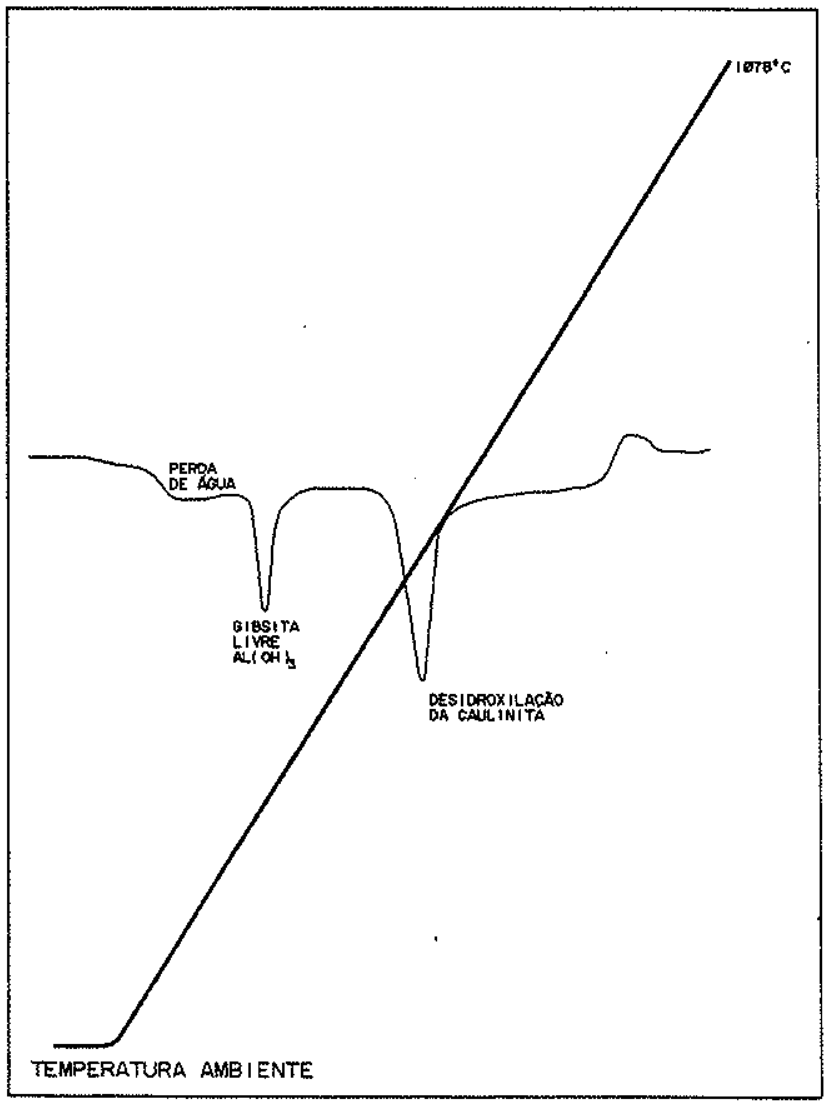

Figura 84: Gráfico de ATD mostrando o comportamento da argila da amostra do ponto 22.11.91-01B do leque aluvial Cambará quando submetida à altas temperaturas. 
Em oito amostras de argila que foram coletadas na seção-tipo da Formação Alexandra, Angulo (1995) realizou análises com difratometria de raios-X e constatou a presença de caulinita.

Os resultados dos métodos que foram realizados para identificação dos tipos de argila, indicaram que tanto a Formação Alexandra como os leques aluviais quaternários são compostos essencialmente de caulinita, concordando com os resultados obtidos por Angulo (1995).

\subsection{INTERPRETAÇÃO SEDIMENTOLÓGICA E ESTRATIGRÁFICA}

\subsubsection{Formação Alexandra}

\subsubsection{Ambiente Deposicional e Paleoclima}

Tanto em trabalhos mais antigos (Bigarella et al., 1959; Ab'Saber \& Bigarella, 1961; Silva et al., 1981), como nos trabalhos mais recentes (Lima \& Angulo, 1990; Angulo, 1995) sobre a Formação Alexandra, o sistema deposicional de leque aluvial é indicado por todos autores. Entretanto, alguns outros ambientes também foram sugeridos, como flúvio-lacustre (Bigarella et al., 1961) e bajada e playa-lake (Ab'Saber \& Bigarella, 1961).

A partir das descrições realizadas nos itens anteriores pode-se interpretar os processos que originaram esta unidade. A seqüência de sedimentos mais comum da Formação Alexandra é a intercalação de areias e lamas, em cuja sedimentação atuaram agentes e processos de formação diferentes.

As lamas são originárias de fluxos gravitacionais, mais especificamente fluxos de lama (mudflow). Este fato é sugerido pela alta imaturidade do sedimento, com presença de grânulos de quartzo e feldspatos subangulares dispersos em matriz argilosa e estrutura aparentemente maciça, indicando alta viscosidade do agente de transporte. 
As areias, apesar de serem muito pobremente selecionadas e possuirem teores de argila entre 14 e $48 \%$, apresentam melhor arredondamento dos grãos e estruturas sedimentares sindeposicionais, como estratificações tabulares horizontais e cruzadas, de escavação e preenchimento e granodecrescência ascendente, sugerindo processos de tração de alta energia em ambiente fluvial, fato que é corroborado também pela presença de pelotas de argila na base das camadas.

Os cascalhos sustentados por clastos encontrados na região de Guaraqueçaba e nas proximidades da PR 508 (ponto 12.2.92-06), também foram depositados por processos de tração de alta energia em ambiente fluvial, comprovado pela presença de imbricações de seixos, estratificações cruzadas tabulares e paleocanais. A presença de abundante matriz argilo-arenosa, que localmente pode ultrapassar 15\%, faz supor que - meio de transporte deveria ter baixa viscosidade com carga de suspensão. Entretanto, o predomínio de clastos indica a deposição por carga de fundo, como depósitos residuais de canal.

A associação de depósitos descritos sugere fácies distais de leques aluviais, como já interpretado por Angulo (1995). Entretanto, pode-se reconhecer três fácies sedimentológicas atribuídas a fluxos de lama, rios entrelaçados com canais nãoconfinados e rios entrelaçados com canais confinados.

As areias estão relacionadas à fácies de rios entrelaçados (braided) em canais não-confinados, representando períodos de maior disponibilidade de água. As camadas de lama integram a fácies fluxos de lama (mudflow) e representam fases de menor atividade fluvial, com prováveis períodos de chuvas concentradas. A escassez de depósitos cascalhosos na região da PR 508, além de sugerir ambientes de fácies distais de leques aluviais, poderia também indicar a baixa disponibilidade de clastos maiores.

Os cascalhos sustentados por clastos, que são mais comuns na região de Guaraqueçaba, também fazem parte da fácies de rios entrelaçados, possivelmente relacionados a barras longitudinais de canais. A presença deste tipo de depósito na 
região da PR 508, sugere que nesta região a fácies de canais entrelaçados poderia ter sido mais freqüente.

A definição deste tipo de modelo foi também sugerida nos gráficos de diâmetro médio $x$ mediana e mediana $x$ assimetria (Figs. 53 a 57) e, principalmente, nos diagramas CM (Figs. 70 a 72). Os diagramas CM (Passega, 1957) foram muito importantes na definição do modelo proposto, pois os padrões apresentados por Bull (1962 e 1972), para rios entrelaçados e fluxos de lama, se adaptam muito bem ao comportamento das amostras da Formação Alexandra.

Com relação ao paleoclima, Angulo (1995) propõe clima úmido para a Formação Alexandra, diferentemente de outros autores (Bigarella et al., 1965a e 1965b; Fuck et al., 1969; Martin et al., 1988), que consideraram como mais provável o clima semi-árido.

Baseando-se na presença de depósito com argila orgânica, na qual foi constatada assembléia de palinomorfos que sugeriram clima úmido (Lima \& Angulo, 1990), concorda-se com as considerações de Angulo (1995) de que o clima foi úmido durante a deposição da Formação Alexandra. Reineck \& Singh (1980) verificaram que leques aluviais de clima úmido são formados por cursos de água perenes, associados à depósitos de pântanos nas margens dos leques.

A denominação para os leques aluviais de climas úmidos difere de autor para autor. Reineck \& Singh (1980) os chamam de leques úmidos, Galloway \& Hobday (1983) referem-se à esses leques como "dominados por canais" e Schum et al. (1987) definem como leques "fluviais". Para a Formação Alexandra se adotará apenas a designação de leque aluvial de clima úmido.

\subsubsection{Relações Estratigráficas}

Não foram observadas relações de contato diretas entre os depósitos da Formação Alexandra e as outras unidades sedimentares que estão sendo estudadas neste trabalho. As relações estratigráficas aqui baseiam-se nas análises de palinomorfos realizadas para a Formação Alexandra (Lima \& Angulo, 1990), assim 
como nas datações realizadas em alguns leques aluviais quaternários (ver item 6.5.2.3).

\subsubsection{Idade}

Como já foi considerado por Angulo (1995), a idade da Fornação Alexandra foi inferida tentativamente por diversos autores. Ao ser criada, Bigarella et al. (1959) propuseram uma idade terciária, sendo seguidos por Bigarella et al. (1961), Ab'Saber \& Bigarella (1961) e Martin \& Suguio (1986). Martin et al. (1988) tentativamente sugerem idade pliocênica, enquanto que Silva et al. (1981) propuseram idade quaternária. Outras tentativas de posicionamento da Formação Alexandra no Pleistoceno foram realizadas por Bigarella \& Freire (1960), Bigarella et al. (1965a), Fuck et al. (1969) e Rivereau et al. (1969).

Através de análises de palinomorfos de camada argilosa com fósseis vegetais, Lima \& Angulo (1990) atribuiram à Formação Alexandra uma idade entre o Mioceno Inferior e o Mioceno Médio.

\subsubsection{Correlações}

Entre as diversas tentativas de correlações da Formação Alexandra tem-se a sugerida com a Formação Guabirotuba (Bigarella \& Salamuni, 1962) da Bacia de Curitiba, considerada como plio-pleistocênica, sem quaisquer evidências concretas. Azevedo (1981), baseando-se em tecamebas, propôs idade pilocênica à Formação Guabirotuba, mas como discutido por Angulo (1992), pouco se sabe sobre a aplicação desses microorganismos em datação. Bigarella \& Ab'Saber (1964) e Fuck et al. (1969) basearam-se principalmente nos aspectos texturais dos sedimentos, no paleoclima e no ambiente de sedimentação para correlacionar a Formação Guabirotuba com a Formação Alexandra. Entretanto, até o momento a Formação Alexandra sugere origem em clima úmido, enquanto que a presença de calcretes na Formação Guabirotuba é uma evidência de deposição em clima semi-árido (Coimbra \& Riccomini, 1985), indicando que não deve haver correlação entre estas duas unidades. 
A correlação da Formação Alexandra com a Formação Pariqüera-Açu já era admitida por Bigarella \& Mousinho (1965) e Bigarella et al. (1965a), que utilizaram as correlações paleoclimáticas dos ciclos glaciais das altas latitudes através de pediplano (Pd1) e pedimentos (P1 e P2). Apesar de Melo (1990) não ter considerado este método, admitiu que as duas formações são correlacionáveis, devido principalmente à ocorrência de depósitos no vale do Rio Taquari, no Estado de São Paulo próximo à região de Guaraqueçaba no Estado do Paraná, que foram atribuídos à Formação Alexandra (Silva et al., 1981), sendo litologicamente semelhantes aos depósitos da Formação Pariqüera-Açu. Angulo (1995) concordou com esta correlação, ressaltando que a origem climática de ambas formações se deu em clima úmido. Apesar de ainda não ter sido encontrada evidências concretas de idade na Formação Pariqüera-Açu, é cada vez mais evidente que essas duas formações são sincrônicas.

O Grupo Barreiras, referido por Petri \& Fulfaro (1983) como "termo" Barreiras, são sedimentos clásticos que ocorrem quase ininterruptamente ao longo da costa, desde o Rio de Janeiro até o Pará. Tem sido interpretados como depósitos de leques aluviais com provável influência de marés na porção mais distal do sistema. Melo (1990) verificou que, em análises palinológicas realizadas para esta unidade (Arai et al., 1988), o palinomorfo de maior valor estratigráfico (Crassoretitriletes vanraadshooveni), coincide com o que foi encontrado na Formação Alexandra por Lima \& Angulo (1990), sugerindo uma sincronicidade entre as duas unidades.

\subsubsection{Leques Aluviais Quaternários}

\subsubsection{Ambiente Deposicional e Paleoclima}

Tal como na Formação Alexandra, os leques aluviais quaternários exibem intercalações de camadas arenosas e lamosas, ocorrendo algumas vezes camadas cascalhosas. Entretanto, como se observa no diagrama da Fig. 51, que apresenta a porcentagem média das classes texturais por unidade estratigráfica, os leques aluviais quaternários apresentam maior frequência de areia, confirmando a predominância de 
sedimentos arenosos que foi descrita para estas unidades no item 6.2.2.1, sugerindo predomínio de influência fluvial no meio de transporte desses sedimentos.

Nas areias, a seleção é muito pobre e as estratificações cruzadas e as estruturas de escavação e preenchimento, sugerem meio de transporte fluvial em regime de fluxo inferior com processos de tração em alta energia. Ocorreram processos de canibalismo evidenciados pela presença de pelotas de argila em algumas camadas de areia.

A imaturidade e a presença de estrutura maciça das camadas lamosas, faz supor que foram originadas em meio bastante viscoso de fluxos gravitacionais do tipo fluxos de lama (mudflow). Para os cascalhos sustentados por matriz, o processo deposicional foi semelhante, diferenciando-se pela disponibilidade de clastos maiores ou pela proximidade com a área-fonte, sugerindo sugerindo fluxos gravitacionais do tipo fluxo de detritos (debris flow).

A presença de imbricações, estratificações cruzadas e estruturas de escavação e preenchimento nos cascalhos sustentados por clastos, indica ambiente fluvial de alta competência.

Os finos, com laminações plano-paralelas e, às vezes, fósseis vegetais, foram transportados em meio fluvial com alta concentração de sedimentos em suspensão e depositados em meio mais calmo, onde houve redução abrupta da energia de fluxo.

A partir das características sedimentológicas desses depósitos, propõem-se ambientes de leques aluviais com duas fácies distintas: uma fácies proximal e uma fácies distal. A fácies distal pode ainda ser dividida em três fácies: fluxos de lama, rios entrelaçados com canais não confinados, rios entrelaçados com canais confinados e lacustre.

Os cascalhos sustentados por matriz encontrados na base de alguns leques representariam as fácies proximais mais antigas dos leques aluviais, enquanto que os cascalhos encontrados em áreas mais próximas às vertentes da Serra do Mar poderiam indicar a fácies proximal mais jovem. 
$\mathrm{Na}$ fácies distal, as areias representam a fácies de rios entrelaçados com canais não confinados e os cascalhos sustentados por clastos representam a fácies de rios entrelaçados com canais confinados. As lamas estariam relacionados à fácies de corridas de lama enquanto que os finos representariam a fácies lacustre.

$\mathrm{O}$ modelo deposicional proposto de leques aluviais baseou-se também nos resultados de análises granulométricas (Figs. 59 a 66), e nos diagramas CM (Figs. 73 a 78). Nos gráficos de mediana $\mathrm{x}$ assimetria a distribuição dos pontos representando as amostras é bastante dispersa não permitindo reconhecer algum padrão mais definido, enquanto que nos gráficos de diâmetro médio $\mathrm{x}$ mediana os pontos representando as amostras estão mais agrupados, permitindo verificar a distribuição de pelo menos duas populações amostrais: uma com predomínio de lamas, que poderia representar a fácies de fluxos de lama, e outra com predomínio de areias, que poderia representar a fácies de fluvial con canais não confinados. No diagrama CM (Passega, 1957) as amostras destes leques aluviais mostraram o predomínio da fácies de rios entrelaçados (Fig. 78).

A presença comum de depósitos lacustres, aliada a presença de fósseis vegetais, sugere que a formação destes leques aluviais tenha ocorrido sob paleoclima úmido.

Em análises de palinomorfos, realizadas para os leques aluviais, apenas três amostras apresentaram número suficientes de grãos de pólen (ANEXO 2), indicando grande abundância de fungos e presença de ovos de plathelminthes em duas amostras, sugestivos de ambiente bastante úmido. A grande quantidade de pólen de gramineas e de monocotiledôneas tipo Bromeliaceae e Palmae, indicam ora um meio relativamente aberto (tipo orla de brejo), ora um meio mais fechado (bosque). A presença dos gêneros Araucaria e Ilex é sugestiva de temperatura equivalente à atual.

$\mathrm{O}$ ambiente deposicional desses leques aluviais é muito semelhante ao da deposição da Formação Alexandra, com exceção da fácies proximal que não pode ser verificada na Formação Alexandra. Entretanto, a predominância de areias sobre as lamas verificada nos leques aluviais, assim como a presença comum de depósitos lacustres com fósseis vegetais, sugere maior influência fluvial que durante a deposição 
da Formação Alexandra, onde as camadas lamosas são predominantes. Isto também sugere que o clima durante a formação dos leques aluviais quaternários deveria ter sido mais úmido que durante a origem da Formação Alexandra. Estudos sobre depósitos semelhantes aos leques aluviais, encontrados na região litorânea de São Paulo, indicarạm que a origem desses sedimentos pode estar assocịada à "oscilações climáticas, com mobilização local do manto de regolito" (Melo, 1990).

A predominância de sedimentos arenosos é mais evidente nos depósitos do leque aluvial Cubatão, que foram interpretados como de sistema fluvial meandrante (Angulo, 1992). Comparando com os outros leques aluviais, verifica-se que aqui os sedimentos possuem maior maturidade, com menor teor de argila (ANEXO 1), melhor seleção granulométrica e grãos mais bem arredondados, sugerindo maior influência fluvial na origem sedimentar deste leque aluvial em comparação aos outros leques aluviais. Os finos encontrados neste leque aluvial poderiam sugerir a existência de fácies de planície de inundação. Entretanto, as características sedimentológicas do afloramento em que foi encontrado o depósito de finos, estão mascaradas pelo intemperismo, dificultando a sua interpretação.

A imaturidade dos sedimentos (cascalhos sustentados por matriz e lamas) dos leques aluviais Brejatuba, Pombas, Caovi e Miranda, indica que tiveram rápido transporte por fluxos gravitacionais de alta viscosidade. Os cascalhos estão relacionados à movimentos de massa sob ação da gravidade, enquanto que as lamas provavelmente tiveram origem em fluxos de lama (mudflow) não muito frequentes.

\subsubsection{Relações Estratigráficas}

Como já foi descrito no caso da Formação Alexandra, não foram encontradas relações de contatos diretas entre os leques aluviais e aquela formação. Entretanto, os dados de palinologia, tanto dos leques aluviais quaternários como da Formação Alexandra, bem como as datações realizadas no leque aluvial Colônia Pereira e Cambará/Cachoeirinha (item 6.5.2.3), indicam que são unidades estratigraficamente distintas. 
Também não foram encontradas relações de contatos entre os diversos leques aluviais quaternários. Isto deve-se ao fato de apresentarem-se geográficamente isolados uns dos outros, a não ser pela coalescência entre os leques do rios Cambará e Cachoeirinha que foi observada por fotointerpretação, mas sem evidências de campo.

Alguns estudos realizados para sedimentos continentais quaternários (Moura \& Meis, 1986 e Moura \& Mello, 1991), foram usados como modelos na tentativa de se classificar formalmente os leques aluviais quaternários. Nestes trabalhos os sedimentos continentais da região do Bananal, que tem a mesma idade dos leques aluviais aqui tratados, foram classificados como aloformações. Os leques aluviais quaternários, apesar de bem configurados geomorficamente, ocorrem isolados geograficamente e não apresentam descontinuidades entre eles, elemento essencial para a definição de uma unidade aloestratigráfica. Assim sendo, decidiu-se tratá-los como unidades informais, até que hajam mais dados que conduzam a esta proposição.

A partir das descrições realizadas do leque aluvial Cubatão pode-se verificar que se apresenta como um leque aluvial sem correlações com os outros leques aluviais quaternários. Sua configuração geomórfica e seus depósitos sedimentares sugerem que, o processo de formação foi eminentemente fluvial no agente de transporte, diferindo dos outros leques aluviais que, apesar de apresentarem predomínio dos processos fluviais, mostram que os processos de fluxos densos foram relevantes na formação dos depósitos.

\subsubsection{Idade}

Duas amostras foram enviadas ao Laboratório do Centro de Energia Nuclear na Agricultura (C.E.N.A.) em Piracicaba-SP, para datação pelo método do ${ }^{14} \mathrm{C}$, tendo sido obtido os seguintes resultados: 13.850 anos A.P. \pm 120 para a amostra coletada no leque aluvial do rio Colônia Pereira e 8.330 anos A.P. \pm 80 para a amostra do leque aluvial do rio Cambará. Desta forma, os leques aluviais Colônia Pereira, Cambará/Cachoeirinha e, possivelmente, o leque aluvial Morretes estariam posicionados entre o término do Pleistoceno e começo do Holoceno. 
Os leques aluviais Brejatuba, Pombas, Caovi e Miranda devem ser mais recentes que os outros leques aluviais, pois como verificado por Angulo (1995), a pouca dissecação observada em fotointerpretação para estas unidades, indicaria uma idade mais nova, já que os outros leques apresentam-se bastante dissecados e com a presença de até três gerações de leques aluviais.

\subsubsection{Correlações}

A tentativa de correlacionar os leques aluviais com outra unidade estratigráfica já foi feita por Angulo (1995), correlacionando esses leques aluviais com a Formação Iquererim. $\mathrm{O}$ autor usou, além da similaridade sedimentológica, evidências geomorfológicas que sugeriram a existência de pelo menos três gerações de leques aluviais, o que também foi verificado por Bigarella et al. (1961) quando criou a referida formação, que ainda posicionou-a no Pleistoceno, sem evidências concretas. Para Angulo (op. cit.), devido à mudança do nível de base, as gerações mais antigas dos leques aluviais foram depositadas em posições topográficas mais elevadas e, consequentemente, as gerações mais jovens teriam sido depositadas em níveis topográficos mais baixos, mais próximas à planície costeira. As datações que foram realizadas para os leques aluviais Colônia Pereira e Cambará/Cachoeirinha, referem-se às amostras de fósseis vegetais encontradas em porções distais desses leques, o que indicaria que essas datações (13.850 anos A.P. \pm 120 para o leque aluvial Colônia Pereira e 8.330 anos A.P. \pm 80 para o leque aluvial Cambará/Cachoeirinha) estariam relacionadas às gerações mais jovens desses leques. Sendo assim, poderia se supor que as partes distais da Formação Iquererim estariam correlacionadas com as porções distais dos leques aluviais do Estado do Paraná.

Os sedimentos estudados na região litorânea de São Paulo e denominados informalmente como "depósitos de cascalhos do nível superior de terraços" (Melo, 1990), apresentam semelhança sedimentológica e de ambiente deposicional dos leques aluviais quaternários do Estado do Paraná, tendo sido originados em processos de leques aluviais, com corridas de lamas e sistema fluvial entrelaçado. Entretanto, 
parece prematuro fazer uma correlação entre estas unidades, já que Melo (1990) posiciona esses depósitos entre o Plioceno e o Pleistoceno, sem apresentar elementos de datação. Portanto, deverá se esperar por mais evidências que justifiquem a corrrelação entre estas unidades.

\section{CONCLUSÕES}

Os afloramentos da Formação Alexandra ocorrem em duas regiões que apresentam características sedimentológicas distintas: região à margem da estrada Alexandra - Matinhos e região próxima ao rio Guaraqueçaba.

Em trabalhos de campo não foram encontrados os depósitos sedimentares que Angulo (1995) incluiu à Formação Alexandra e que deveriam estar situados à cerca de $5 \mathrm{~km}$ da vila de Alexandra. Verificou-se apenas a ocorrência de granito alterado no local e, desta forma, optou-se pela exclusão desses depósitos da referida formação.

Os depósitos que ocorrem na região de Guaraqueçaba e que foram excluídos por Angulo (1995), foram reincluídos a esta formação, por apresentarem características sedimentológicas semelhantes às encontradas na seção-tipo.

Nas proximidades com a estrada PR 508 (Alexandra-Matinhos), a predominância de camadas de lamas e areias com estratificações cruzadas e estruturas de escavação e preenchimento, indicam que os fluxos gravitacionais, especificamente as corridas de lama, e fluxos trativos que corresponderiam a rios entrelaçados, foram os processos mais atuantes durante a formação destes depósitos. Raramente ocorre cascalho sustentado por clastos. A presença de pelotas de argila em camadas de areias, sobrepostas às camadas de lamas, indica a ocorrência de canibalismo. Estes sedimentos foram interpretados como pertencentes à fácies distal de um sistema de leques aluviais. 
Na região de Guaraqueçaba, predominam os cascalhos sustentados por clastos, sugerindo que os processos que mais atuaram nesta região foram do tipo sistemas fluviais de rios entrelaçados com canais confinados, também relacionados à fácies distal de leque aluvial.

Os estudos sedimentológicos, realizados para a Formação Alexandra, mostraram que no topo da seção-tipo ocorre pelo menos uma camada de areia arcosiana relacionada à sistema fluvial de rios entrelaçados, diferindo do que foi apresentado por Angulo (1995), que nesta parte da seção, descreveu depósitos de lamas depositados por fluxos densos.

A associação de depósitos estudados da Formação Alexandra sugere modelo de fácies distais de leques aluviais, sendo dividida em fácies de fluxos de lama, rios entrelaçados com canais não-confinados e rios entrelaçados com canais confinados. As areias estão relacionadas à fácies de rios entrelaçados com canais não-confinados, as lamas integram a fácies de fluxos de lama e os cascalhos sustentados por clastos a fácies de rios entrelaçados com canais confinados.

A correlação entre a Formação Alexandra e a Formação Guabirotuba, admitida por vários autores (Bigarella \& Salamuni, 1962; Bigarella \& Ab'Saber, 1964; Fuck et al., 1969 e Azevedo, 1981) não foi considerada neste trabalho, pois além da Formação Guabirotuba não ter evidências concretas de datação, a presença de calcretes em seus depósitos indicam deposição em clima semi-árido (Coimbra \& Riccomini, 1985), enquanto que, até o momento, a Formação Alexandra sugere origem em clima úmido (Lima \& Angulo, 1990 e Angulo, 1995).

Apesar da Formação Pariqüera-Açu ainda prescindir de datações, semelhanças sedimentológicas verificadas entre esta formação e a Formação Alexandra indicam que há, cada vez mais, sincronicidade entre elas como sugerido por Melo (1990).

Os leques aluviais quaternários foram tratados como unidades informais. As descrições de campo mostraram que possuem uma diversidade de tipos 
sedimentológicos muito maior do que era considerado em trabalhos prévios, quando receberam diversas denominações, como "depósitos terrígenos" (Bigarella, 1965) ou incluídos em "coluviões de pé de relevo e aluviões fluviais" (Martin et al., 1988).

Através das características geomórficas e dos estudos sedimentológicos, foi possivel dividir os leques aluviais em dois grupos distintos: o primeiro grupo composto pelos leques aluviais Colônia Pereira, Cambará/Cachoeirinha e Morretes, e o segundo grupo composto pelos leques aluviais Brejatuba, Pombas, Caovi e Miranda.

No primeiro grupo de leques aluviais, o predomínio de depósitos de areia, com estruturas de escavação e preenchimento e estratificações cruzadas, sugerem maior influência fluvial no meio de transporte desses leques aluviais. Subsidiariamente ocorrem lamas e cascalhos sustentados por matriz que teriam se depositado em processos de fluxos gravitacionais. A presença de cascalhos sustentados por clastos, com imbricações e estruturas de escavação e preenchimento, indicaram ambiente fluvial de alta competência. Raramente ocorrem depósitos de finos, que foram depositados em ambiente fluvial de alta concentração de sedimentos.

O modelo deposicional proposto para os leques aluviais Colônia Pereira, Cambará/Cachoeirinha e Morretes, também pode ser dividido em fácies proximal, representada por cascalhos sustentados por matriz, e fácies distal. A fácies distal foi dividida em fácies de fluxos de lama, de rios entrelaçados com canais não-confinados, de rios entrelaçados com canais confinados e lagos. As lamas representam a fácies fluxos de lama, as areias integram a fácies de rios entrelaçados com canais nãoconfinados, os cascalhos sustentados por clastos representam a fácies de rios entrelaçados com canais confinados e os finos estão relacionados à fácies de lagos.

As datações com o método ${ }^{14} \mathrm{C}$, realizadas em duas amostras correspondentes aos leques aluviais Colônia Pereira e Cambará/Cachoeirinha, indicam que foram depositados no limite Pleistoceno-Holoceno, sendo que as análises palinológicas indicaram um paleoclima úmido, semelhante ao clima atual. Dissecações verificadas em fotointerpretação, sugerem que existam pelo menos três gerações de leques aluviais, o que também foi verificado por Angulo (1995). 
As similaridades sedimentológicas e geomórficas entre estes leques aluviais e a Formação Iquererim, indicaram a possibilidade de uma correlação litoestratigráfica entre estas unidades, como já havia sido sugerido por Angulo (1995).

Os leques aluviais Brejatuba, Pombas, Caovi e Miranda também foram tratados como unidades informais. Suas características sedimentológicas indicam que os fluxos gravitacionais do tipo fluxo de detritos, predominaram na formação dos sedimentos, diferindo dos outros leques aluviais que tiveram predomínio de processos fluviais.

O leque aluvial Cubatão, em comparação com os outros leques aluviais, apresenta feições geomórficas de declividades mais suaves e sedimentos com maior maturidade, indicando que este leque aluvial teve maior influência fluvial na sua deposição.

\subsection{EVOLUÇÃO PALEOGEOGRÁFICA}

$\mathrm{Na}$ época da deposição da Formação Alexandra (Mioceno Inferior), o relevo de escarpas da Serra do Mar deveria ser semelhante ao atual, mas com um paleoclima mais seco do que o atual, proporcionando a ocorrência de fluxos gravitacionais, com predomínio de corridas de lama. O paleoclima, apesar de ser mais seco que o atual, deveria ser suficientemente úmido para a formação de pequenos corpos de água permanentes, como sugerem as evidências palinológicas analisadas por Lima \& Angulo (1990), a escassez de clastos e de minerais instáveis.

A distribuição dos afloramentos atribuidos à Formação Alexandra, permitem supor que os leques aluviais que originaram esses depósitos deveriam extender-se por grande parte da planície litorânea do Estado do Paraná, integrando um sistema de leques aluviais coalescentes.

Os processos erosivos que dissecaram os depósitos da Formação Alexandra foram bastante rigorosos, não tendo sido encontradas evidências sedimentológicas nem geomórficas de fácies mais proximais de leques aluviais. As análises dos sedimentos 
sugerem que os depósitos remanescentes são representativos de fácies distais originados por fluxos de lama e sistemas fluviais entrelaçados.

Nas unidades aflorantes no litoral paranaense, não se tem registro de sedimentação continental desde a deposição da Formação Alexandra até a deposição dos leques alưviais no final do Pleistoceno. As datações existentes evidenciam que, pelo menos parte dos leques aluviais foram depositados entre 13.000 e 8.000 anos A.P.. Apesar de dissecados por uma drenagem posterior, os leques aluviais ainda guardam evidências geomórficas de sua ligação com as encostas da Serra do Mar, permitindo inferir que a paleogeografia seria muito semelhante à atual.

As características dos sedimentos dos leques aluviais permitem reconhecer duas fácies distintas: uma fácies proximal e uma fácies distal, dividida em fácies de fluxos de lama, rios entrelaçados com canais confinados e não-confinados, e lagos.

As análises palinológicas, indicam que, no momento da deposição dos leques aluviais quaternários, o clima atuante era muito parecido com o atual, assim como a vegetação que era do tipo mata atlântica e restinga.

Os leques aluviais Brejatuba, Pombas, Caovi e Miranda, conforme características geomórficas de pouca dissecação, representam processos de deposição mais modernos do que os leques aluviais Colônia Pereira, Cambará/Cachoeirinha e Morretes. Os sedimentos foram originados por fluxos gravitacionais, com predomínio de fluxo de detritos, sendo muito restritas as corridas de lama. 


\section{REFERÊNCIAS BIBLIOGRÁFICAS}

AB'SÁBER, A.N.; BIGARELLA, J.J. 1961. Superfícies aplainadas-do Primeiro Planalto do Paraná. Bol. Par. Geogr. Curitiba, n.4 e 5. p.116-125.

ANGULO, R.J. 1992. Geologia da planície costeira do estado do Paraná. São Paulo. (tese de doutoramento, Inst. Geoc., USP). 334p.

ANGULO, R.J. 1995. Caracterização e reavaliação da Formação Alexandra (Terciário) e de sedimentos continentais associados a vertentes, no litoral do estado do Paraná, Brasil. An. Acad. bras. Ci. Rio de Janeiro, 67(4):89102.

ARAI, M.; UESUGUI, N.; ROSSETTI, D. de F.; GÓES, A.M. 1988. Considerações sobre a idade do Grupo Barreiras no nordeste do Estado do Pará. In: CONGRESSO BRASILEIRO DE GEOLOGIA, 35, Belém, 1988. Anais... Belém, SBG. v2. p.738-752.

AZEVEDO, F.F. 1981. Thecamoebianos e organófitos na Formação Guabirotuba. In: SIMP. REG. GEOL., 3. Curitiba. 1981. Atas... Curitiba, SBG. v.2. p.226-242.

BECKER, R.D. 1976. Sedimentologia e estratigrafia do Quaternário do baixo vale do rio Itajaí-Mirim (SC). Porto Alegre (dissertação de mestrado, UFRS).

BIGARELlA, J.J. (Coord.). 1978. A Serra do Mar e a porcão oriental do Estado do Paraná: um problema de segurança ambiental e nacional: contribuição à geografia, geologia e ecologia regional. Curitiba, Sec. Plan.: Ass. Def. Educ. Amb. 248p.

BIGARELLA, J.J. 1946. Contribuição ao estudo da planície litorânea do estado do Paraná. Arq. de Biol. Tecn.

BIGARELLA, J.J. 1964. Variações climáticas no Quaternário e suas implicações no revestimento florístico do Paraná. Bol. Par Gegr., Curitiba, n.10 a 15. p.211-231.

BIGARELLA, J.J. 1965. Nota explicativa acompanhando a folha geológica de Paranaguá. Bol. Univ. Par. Geol., Curitiba, n.13. p.15.

BIGARELLA, J.J.; AB'SABER, A.N. 1964. Paleogeographische und palaokimatische aspekte des kanozoikums in sübbrasilien. Zeitsche. Geom., Berlim, v.8, n.3.p.286-312.

BIGARELLA, J.J.; BECKER, R.D. (Ed.) 1975. International Symposium on the Quaternary. Topics for discussion. Bol. Par. Geoc., Curitiba, n. 33. p. 169276.

BIGARELLA, J.J.; FREIRE, S.S. 1960. Nota sobre a ocorrência de cascalheiro marinho no litoral do Paraná. Bol. Un. Par. Geol., Curitiba, n.6 109p. 
BIGARELLA, J.J.; MARQUES FILHO, P.L.; AB'SÁBER, AN. 1961. Ocorrência de sedimentos remanescentes nas fraldas da Serra do Iquererim (Garuva, SC). Curitiba, Universidade do Paraná, Inst. Geol. p.82-93. (Bol. Par Geogr., 4 e 5 ).

BIGARELLA, J.J.; MOUSINHO, M.R. 1965. Contribuição ao estudo da Formação Pariqüera-Açu (Estado de São Paulo). Bol. Par. Geogr.. Curitiba, n.15 e 17. p.17-41.

BIGARELlA, J.J.; MOUSINHO, M.R.; SILVA, J.X. 1965a. Pediplanos, pedimentos e seus depósitos correlativos no Brasil. Bol.Par. Geogr., Curitiba, n.15 e 17. p.117-151.

BIGARELLA, J.J.; MOUSINHO, M.R.; SILVA, J.X. 1965b. Processes and environments of the brazilian Quaternary. Curitiba, Univ Paraná. 71p.

BIGARELLA, J.J.; SALAMUNI, R, 1962. Caracteres texturais dos sedimentos da bacia de Curitiba (Contribuição à geologia geral). Bol. Un. Par Geol., Curitiba, n. 7. p.1-164.

BIGARELLA, J.J.; SALAMUNI, R.; MARQUES FILHO, P.L. 1959. Ocorrência de depósitos sedimentares no litoral do estado do Paraná (Formação Alexandra). Curitiba, Inst. Biol. Pesq. Tecn. 7p. (Notas Preliminares e Estudos, 1).

BLISSEMBACH, E. 1954. Geology of alluvial fans in semi-arid regions. Bull. Geol. Soc. Am. 65:175-189.

BULL, W.B. 1962. Relation of textural (CM) patterns to depositional environment of alluvial-fan deposits. Jour. Sed. Petr., 32(2):211-216.

BULL, W.B. 1964. Geomorphology of segmented alluvial fans in Western Fresno County, Califórnia. Prof. Pap. U.S. Geolo. Surv. 352-E:89-129.

BULL, W.B. 1972. Recognition of alluvial fan deposits in the stratigraphic record. In: HAMBLIN, W.K.; RIGBY, J.K. (Eds.), Recognition of ancient sedimentary environments. Tulsa, Soc. Econ. Paleont. Miner. p.63-83 (Spec. Pub. 16).

CHEN, T.J.; SANTOS, P.S.; FERREIRA, H.C.; CALIL, S.F.; ZANDONADI, A.R.; CAMPOS, L.V. 1974. Determinação da capacidade de troca de cátions e da área específica de algumas argilas e caulins cerâmicos brasileiros pelo azul de metileno e sua correlação com algumas propriedades tecnológicas. Cerâmica, 79, julho a setembro, p. 305-326.

COIMBRA, A.M.; RICCOMINI, C. 1985. Considerações paleoambientais sobre as ocorrências de caliche nas bacias de Curitiba (PR), Taubaté (SP) e Resende (RJ). An. Acad. bras. Ci., Rio de Janeiro, 54(4):517-518.

COLLINSON, J.D.; THOMPSON, D.B. 1989. Sedimentary structures. London, Unwin Hyman. 207p.

CORDANI, U.G.; GIRARDI, V.A.V. 1967. Geologia da folha de Morretes. Curitiba, Univ. do Paraná. 40p. 1 mapa. (Boletim, 26. Geologia).

CUNHA NETO, A.F. 1984a. Projeto Ouro; área I: relatório final de pesquisa. Curitiba, MINEROPAR. 26p., anexo. 
CUNHA NETO, A.F. 1984b. Projeto Ouro: área Il Curitiba, MINEROPAR. n.p., 3 mapas.

DANA, J.D. 1976. Manual de mineralogia. Rio de Janeiro. Liv. Téc Cient. Ed. v.2. p. $355-642$.

FOLK, R.L. 1954. The distinction between grain-size and mineral composition in sedimentary rock nomenclature. Jour. Geol., Chicago, v. 62, n. 4. p. 344359.

FOLK, R.L.; WARD, W.C. 1957. Brazos river bar: a study in the significance of grain size parameters . Jour. Sed. Petr., Tulsa, v. 27. p.3-26.

FUCK, R.A.; TREIN, E.; MURATORI, A.; RIVEREAU, J.C. 1969. Mapa geológico preliminar do litoral, da Serra do Mar e parte do primeiro planalto no estado do Paraná. Curitiba, IGUFP. p.123-152. (Bol. Par. Geoc., 27).

GALLOWAY, W.E.; HOBDAY, D.K. 1983. Terrigenous clastic depositional systems. New York, Berlim, Heidelberg, Tokyo, Springer-Verlag. 672p.

GIANNINI, P.C.F. 1993. Sistemas deposicionais no Quaternário costeiro entre Jaguaruna e Imbituba, S.C.. São Paulo. (tese de doutoramento, Inst. Geoc., USP). $2 v ., 439 p$.

HOOKE, R.L.B. 1967. Process on arid alluvial fans. Journ. Geol. 75:438-460.

IPARDES. 1989. Zoneamento do litoral paranaense. Curitiba, Secr. Plan.: IPARDES. 175p.

KOCHEL, R.C.; JOHNSON, R.A. 1984. Geomorphology and sedimentology of humid-temperate alluvial fans, Central Virginia. In: KOSTER, E.H.; STEEL, R.J. (Eds.). Sedimentology of gravels and conglomerates. Canadian Society of Petroleum Geologists, Memoir 10. p. 109-122.

LIMA, M.R.; ANGULO, R.J. 1990. Descoberta de microflora em um nível linhítico da Formação Alexandra, Terciário da estado do Paraná, Brasil. São Paulo, An. Acad. bras. Ciênc. 62(4):357-371.

MAACK, R. 1947. Breves notícias sobre a geologia dos estados do Paraná e Santa Catarina. Arq. Biol. Tecn. Curitiba, Inst. Biol. Pesq. Tecn. 2:67-154.

MANGE, M.A.; MAURER, H.F.W. 1992. Heavy minerals in colour. London. Chapman \& Hall. 149p.

MARTIN, L.; SUGUIO, K. 1986. Excursion route along the coastal plains of the states of Paraná and Santa Catarina. In: INTERNATIONAL SYMPOSIUM ON SEA LEVEL CHANGES AND QUATERNARY SHORELINES, SÃO PAULO, 1986. São Paulo, IGCP/IGUSP/ABEQUA. 124p. (Spec. Publ., 1).

MȦRTIN, L.; SUGUIO, K.; FLEXOR, J.M.; AZEVEDO, A.E.G. 1988. Mapa geológico do Quaternário costeiro dos estados do Paraná e Santa Catarina; escala 1:200.000. Brasília, DNPM. 40p. 2 mapas. (Série Geológica, 28. Seção Geológica Básica, 18).

MELO. M.S. 1990. A Formação Pariquiera-Açu e depósitos relacionados: Sedimentação, tectônica e geomorfogênese. São Paulo, 211p. (dissertação de mestrado, Inst. Geoc., USP). 
MIALL, A.D. 1981. Analysis of fluvial depositional systems. Tulsa, AAPG. 75p.

(AAPG Education Course Note Series, 20).

MINEROPAR - MINERAIS DO PARANÁ S.A. 1989. Mapa geológico do estado do Paraná. Brasília. Dep. Nac. Prod. Min. (DNPM). Escala 1:650.000.

MOURA, J.R.S.; MEIS, M.R.M. 1986. Contribuição à estratigrafia do Quaternário Superior no médio vale do rio Paraíba do Sul - Bananal, SP. An. Acad. bras. Ci. Rio de Janeiro, 58(1):89-102.

MOURA, J.R.S.; MELO, C. 1991.

N.A.C.S.N. 1983. North American stratigraphic code. Amer. Assoc. Petrol. Geol. Bull. 67(5):841-875.

PASSEGA, R. 1957. Texture and characteristic of clastic deposition. Amer. Assoc. Petr. Geol. Bull., Tulsa, v. 41, n. 9. p. 1952-1984.

PETRI, S.; FÚLFARO, V.J. 1983. Geologia do Brasil. São Paulo, T.A. Queiroz Ed./EDUSP. 631p.

PETTIJOHN, F.J. 1975. Sedimentary rocks, $3^{\text {a }}$ ed. New York. Harper \& Row Pub1. $628 \mathrm{p}$.

RAPP, A.; FAIRBRIDGE, R.W. 1968. Talus fan or cone; scree and cliff debris. In: FAIRBRIDGE, R.W. Encyclcpedia cf geomorphology. Stroudsburg. D. Hutchinson \& Ross. p.1106-1109.

REINECK, H.E.; SINGH, I.B. 1980. Depositional sedimentare environments. Berlim, Heidelberg, New York, Springer-Verlag. 551p.

RICCOMINI, C. 1989. O Rift Continental do Sudeste do Brasil. São Paulo. (tese de doutoramento, Inst. Geoc., USP). 256p.

RIVEREAU, J.C.; FUCK, R.A.; MURATORI, A.; TREIN, E. 1969. Paranaguá, folha geológica. Curitiba, Comissão da Carta Geológica do Paraná. Escala 1:70.000.

RUST, B.R.; KOSTER, E.H. 1984. Coarse alluvial deposits. In: WALKER, R.G. (Ed.), Fácies Models, Hamilton, Geoscience Canada, p. 53-69. (Reprint Series, 1).

SCHUMM, S.A.; MOSLEY, M.P.; WEAVER, W.E. 1987. Experimental fluvial geomorphology. New York, John Wiley \& Sons. 338p.

SHEPARD, F.P. 1954. Revised nomenclature for depositional coastal features. Amer. Ass. Petr. Geol. Bull., Tulsa. v.36, n.10, p.1902-1912.

SILVA, A.T.S.F. da; FRANCISCONI, O.; GODOY, A.M. DE; BATOLLA Jr., F. 1981. Projeto integraç̃̃o e detalhe geológico no Vale do Ribeira; relatório final, integração geológica. São Paulo, CPRM, Sup. Reg. de São Paulo. 15v.

SUGUIO, K. 1973. Introdução à sedimentologia. São Paulo. E. Blücher Ed. 317p.

SUGUIO, K. 1980. Rochas Sedimentares. São Paulo. E. Blücher Ed. 500p.

SUGUIO, K.; BIGARELLA, J.J. 1990. Ambientes Fluviais, Florianópolis, Ed. UFPR/UFSC. $183 \mathrm{p}$. 
TESSLER, M.G.; SUGUIO, K. 1987. Características sedimentológicas da Formação Cananéia (Pleistoceno Superior) na área Paranaguá-Antonina (Estado do Paraná, Brasil). Ass. Bras. Est. Quat., São Paulo, Publ. Avulsa $n^{\circ} 2$. p. 43-54.

VILAS BOAS, G. da S.; BITTENCOURT, A.C.da S.; FARIAS, F.F. de. 1992.

Estratigrafia e sedimentologia da Formação Barreiras na região do Recôncavo Baiano. In: CONGRESSO BRASILEIRO DE GEOLOGIA, 37, São Paulo, 1992. Bol. Res. Exp. São Paulo, v.2. p.427-428. 


\section{ANEXO 1 - RELAÇÃO DAS AMOSTRAS COLETADAS E RESULTADOS DAS ANÁLISES GRANULOMÉTRICAS}

Abreviações das tabelas:

CLAS. CAMPO - classificação adotada para a descrição dos sedimentos.

DES. PA. - desvio padrão.

ASSIM - assimetria.

CURT. - curtose.

DIA. ME. - diâmetro médio.

MEDIAN - mediana.

PERC. - percentil.

GRAN. - grânulos.

SIL. +ARG. - silte + argila.

CLASS. SHEPARD - classificação de Shepard (1954). 
Tabela 1A: Relação de amostras da Formação Alexandra (região de Alexandra) e resultados das análises granulométricas

\begin{tabular}{|c|c|c|c|c|c|c|c|c|c|c|c|c|}
\hline AMOSTRAS & CLAS. CAMPO & DES. PA. & ASSIM. & CURT & DIA. ME. & MEDIAN & PERC. & SEDXOS & GRAN. & AREIA & SIL.+ARG. & CLASS. SHEPARD \\
\hline $22.10 .91-02 \mathrm{~A}$ & areia arcoziana & 3.61 & 0.49 & 0.52 & 3.37 & 1.88 & -1.19 & 0.00 & 2.80 & 61.88 & 35.32 & areia argilosa \\
\hline $22.10 .91-02 \mathrm{C}$ & areia arcoziana & 3.56 & 0.64 & 0.51 & 3.33 & 1.41 & -1.07 & 0.00 & 1.20 & 63.34 & 35.47 & areia argilosa \\
\hline $22.10 .91-02 \mathrm{E}$ & areia arcoziana & 3.42 & 0.67 & 0.52 & 3.33 & 1.40 & -1.01 & 0.00 & 1.11 & 68.66 & 30.24 & areia argilosa \\
\hline $30.10 .91-06 \mathrm{~A}$ & areia arcoziana & 3.70 & 0.55 & 0.51 & 3.29 & 1.57 & -1.15 & 0.00 & 4.01 & 53.05 & 42.95 & areia argilosa \\
\hline $20.2 .91-01 \mathrm{C}$ & areia arcoziana & 3.18 & 0.41 & 1.33 & 2.51 & 1.56 & -1.67 & 1.00 & 6.23 & 71.47 & 21.30 & areia \\
\hline $12.2 .92-06 \mathrm{D}$ & areia arcoziana & 3.15 & 0.48 & 1.26 & 2.56 & 1.48 & -1.17 & 0.00 & 5.43 & 73.92 & 20.65 & areia \\
\hline 20.2.92-01E & areia arcoziana & 1.88 & 0.43 & 1.31 & 1.62 & 1.24 & -1.03 & 0.00 & 1.30 & 84.40 & 14.30 & areia \\
\hline $12.2 .92-06 \mathrm{~B}$ & areia arcoziana & 3.18 & 0.49 & 0.61 & 3.85 & 2.53 & -0.63 & 0.00 & 0.30 & 67.34 & 32.36 & areia argilosa \\
\hline 26.9.91-01J & areia arcoziana & 3.19 & 0.43 & 1.12 & 2.56 & 1.60 & -1.44 & 0.00 & 7.53 & 69.64 & 22.82 & areia \\
\hline $22.10 .91-03 \mathrm{~A}$ & areia arcoziana & 3.23 & 0.53 & 0.93 & 3.36 & 1.94 & -0.96 & 0.00 & 0.87 & 70.28 & 28.84 & areia argilosa \\
\hline $22.10 .91-03 \mathrm{~B}$ & areia arcoziana & 3.52 & 0.46 & 0.70 & 3.36 & 1.96 & -1.45 & 0.03 & 5.35 & 60.99 & 33.62 & areia argilosa \\
\hline $22.10 .91-03 \mathrm{E}$ & areia arcoziana & 3.10 & 0.55 & 1.13 & 2.71 & 1.48 & -1.18 & 0.00 & 2.00 & 74.24 & 23.76 & areia \\
\hline $30.10 .91-01$ & areia arcoziana & 3.23 & 0.45 & 0.52 & 3.93 & 2.72 & -0.47 & 0.00 & 0.18 & 61.46 & 38.36 & areia argilosa \\
\hline $22.10 .91-03 \mathrm{C}$ & areia arcoziana & 3.29 & 0.55 & 0.86 & 3.43 & 1.90 & -0.74 & 0.00 & 0.21 & 72.58 & 27.20 & areia argilosa \\
\hline 26.9.91-01F & areia fina & 3.11 & 0.28 & 0.59 & 4.62 & 3.81 & -0.28 & 0.00 & 0.00 & 51.91 & 48.09 & areia argilosa \\
\hline 26.9.91 $01 \mathrm{C}$ & areia grossa & 3.76 & 0.33 & 0.65 & 3.24 & 2.19 & -1.65 & 9.72 & 11.16 & 53.98 & 25.14 & areia síltica \\
\hline $22.10 .91-02 \mathrm{G}$ & areia grossa & $\longdiv { 3 . 4 4 }$ & 0.67 & 0.51 & 3.35 & 1.40 & -0.98 & 0.00 & 0.94 & 69.96 & 29.10 & areia argilosa \\
\hline $12.2 .92-06 \mathrm{~F}$ & areia grossa & 3.01 & 0.65 & 1.14 & 1.45 & 0.24 & -1.26 & 0.00 & 20.68 & 60.14 & 19.19 & areia \\
\hline $22.10 .91-01$ & areia grossa & 3.52 & 0.53 & 0.53 & 3.41 & 1.82 & -1.11 & 0.00 & 2.78 & 64.41 & 32.82 & areia argilosa \\
\hline $22.10 .91-03 \mathrm{~J}$ & areia grossa & 3.38 & 0.65 & 0.52 & 3.54 & 1.70 & -0.74 & 0.00 & 0.35 & 67.97 & 31.68 & areia argilosa \\
\hline $29.10 .91-01 B$ & areia grossa & 3.71 & 0.52 & 0.52 & 3.29 & 1.64 & -1.17 & 0.00 & 5.27 & 58.93 & 35.80 & areia argilosa \\
\hline 26.9.91-01B & areia grossa & 2.59 & 0.48 & 1.05 & 1.60 & 0.98 & -1.16 & 0.00 & 4.59 & 77.78 & 17.64 & areia \\
\hline $29.10 .91-02 \mathrm{E}$ & areia grossa & 3.59 & 0.29 & 0.52 & 3.97 & 3.06 & -1.08 & 0.00 & 2.03 & 49.02 & 48.95 & areia argilosa \\
\hline 12.2.92-06E & casc. sust/clastos & 3.36 & 0.58 & 1.12 & 1.68 & 0.38 & -1.72 & 7.35 & 23.67 & 55.67 & 13.30 & areia \\
\hline
\end{tabular}




\begin{tabular}{|c|c|c|c|c|c|c|c|c|c|c|c|c|}
\hline $29.10 .91-01 \mathrm{~A}$ & finos & 2.14 & -0.67 & 1.56 & 7.36 & 8.38 & 0.84 & 0.00 & 0.00 & 10.53 & 89.48 & argila síltica \\
\hline $20.2 .92-01 \mathrm{~A}$ & finos & 1.79 & -0.57 & 1.07 & 7.47 & 8.13 & 2.89 & 0.00 & 0.00 & 9.64 & 90.37 & argila siltica \\
\hline $26.9 .91-01 \mathrm{~A}$ & lama & 2.79 & -0.72 & 0.70 & 6.59 & 8.08 & -0.38 & 0.00 & 0.00 & 29.95 & 70.05 & argila arenosa \\
\hline $22.10 .91-02 \mathrm{~B}$ & lama & 3.04 & -0.74 & 0.64 & 6.31 & 8.05 & -1.01 & 0.00 & 1.04 & 33.33 & 65.63 & argila arenosa \\
\hline $22.10 .91-02 \mathrm{~F}$ & lama & 3.00 & -0.75 & 0.72 & 6.56 & 8.21 & -1.12 & 0.00 & 2.80 & 25.21 & 71.99 & argila arenosa \\
\hline $29.10 .91-02 \mathrm{~A}$ & lama & 2.64 & -0.72 & 0.91 & 6.77 & 8.24 & 0.73 & 0.00 & 0.00 & 20.91 & 79.09 & argila arenosa \\
\hline 29.10.91-02D & lama & 3.34 & -0.46 & 0.63 & 5.57 & 6.75 & -1.20 & 0.00 & 2.10 & 35.20 & 62.70 & argila arenosa \\
\hline $30.10 .91-01 \mathrm{~B}$ & lama & 3.39 & -0.04 & 0.55 & 4.78 & 4.83 & -0.60 & 0.00 & 0.00 & 45.43 & 54.57 & areia argilosa \\
\hline $12.2 .91-06 \mathrm{C}$ & lama & 2.64 & 0.11 & 0.58 & 5.32 & 5.03 & 0.89 & 0.00 & 0.00 & 40.71 & 59.29 & areia síltico argilosa \\
\hline $29.10 .91-02 \mathrm{~F}$ & lama & 2.52 & \begin{tabular}{|l|}
-0.69 \\
\end{tabular} & 0.88 & 6.77 & 8.15 & 1.14 & 0.00 & 0.00 & 23.48 & 76.52 & argila arenosa \\
\hline 20.2.92-01D & lama & 2.43 & -0.65 & 1.04 & 6.89 & 7.92 & 0.28 & 0.00 & 0.00 & 16.13 & 83.88 & argila síltica \\
\hline $30.10 .91-01 \mathrm{~A}$ & lama & 3.50 & -0.63 & 0.57 & 5.62 & 7.38 & -1.08 & 0.00 & 2.05 & 44.61 & 53.34 & argila arenosa \\
\hline $22.10 .91-02 \mathrm{D}$ & lama & 2.68 & -0.73 & 1.03 & 6.79 & 8.29 & 0.50 & 0.00 & 0.00 & 21.69 & 78.31 & argila arenosa \\
\hline $29.10 .91-01 \mathrm{C}$ & lama & 2.72 & -0.74 & 1.94 & 6.88 & 8.37 & 0.22 & 0.00 & 0.00 & 18.83 & 81.17 & argila arenosa \\
\hline $20.2 .92-01 \mathrm{~B}$ & lama & 3.12 & -0.05 & 0.69 & 4.82 & 4.83 & -1.00 & 0.00 & 1.02 & 41.15 & 57.84 & areia síltico argilosa \\
\hline $30.10 .91-06 \mathrm{~B}$ & lama & 2.57 & -0.73 & 3.08 & 7.10 & 8.45 & 0.36 & 0.00 & 0.00 & 17.88 & 82.11 & argila arenosa \\
\hline $22.10 .91-03 \mathrm{I}$ & lama & 3.01 & -0.75 & 0.72 & 6.58 & 8.22 & -1.03 & 0.00 & 1.25 & 27.64 & 71.11 & argila arenosa \\
\hline $22.10 .91-03 \mathrm{~K}$ & lama & 2.53 & -0.73 & 3.08 & 7.18 & 8.44 & 0.09 & 0.00 & 0.00 & 16.11 & 83.89 & argila arenosa \\
\hline $22.10 .91-03 \mathrm{H}$ & lama & 3.31 & -0.76 & 0.61 & 6.10 & 8.10 & -0.92 & 0.00 & 0.82 & 37.27 & 61.91 & argila arenosa \\
\hline $26.9 .91-01 \mathrm{~K}$ & lama & 2.65 & -0.71 & 0.98 & 6.79 & 8.17 & 0.18 & 0.00 & 0.00 & 21.22 & 78.78 & argila arenosa \\
\hline $12.2 .92-06 A$ & lama & 2.61 & -0.71 & 0.70 & 6.75 & 8.22 & 0.76 & 0.00 & 0.10 & 23.54 & 76.36 & argila arenosa \\
\hline MEDIA & & 3.06 & 0.01 & 0.93 & 4.58 & 4.41 & -0.60 & 0.41 & 2.75 & 47.73 & 49.11 & 100 \\
\hline
\end{tabular}


Tabela 1B: Relação de amostras da Formação Alexandra (região de Guaraqueçaba) e resultados das análises granulométricas

\begin{tabular}{|c|c|c|c|c|c|c|c|c|c|c|c|c|}
\hline AMOSTRAS & CLASS. CAMPO & DES. PA. & ASSIM. & CURT. & DIA. ME. & MEDIAN & PERC. & SEIXOS & GRAN. & AREIA & SIL.+ARG. & CLASS. SHEPARD \\
\hline $26.3 .92-03 \mathrm{D}$ & areia arcoziana & 3.08 & 0.40 & 0.94 & 2.79 & 1.90 & -1.32 & 0.00 & 3.91 & 68.47 & 27.63 & areia síltica \\
\hline $13.2 .92-01 \mathrm{D}$ & areia arcoziana & 3.56 & 0.77 & 1.39 & 2.77 & 0.53 & -1.04 & 0.00 & 1.35 & 76.77 & 21.88 & areia \\
\hline $26.3 .92-02 \mathrm{C}$ & areia arcoziana & 2.90 & 0.56 & 1.39 & 2.59 & 1.43 & -1.06 & 0.00 & 1.66 & 76.62 & 21.73 & areia \\
\hline $13.2 .92-01 \mathrm{C}$ & areia arcoziana & 2.86 & 0.55 & 0.57 & 4.33 & 2.98 & -0.12 & 0.00 & 0.16 & 60.28 & 39.55 & areia argilosa \\
\hline $19.2 .92-01 \mathrm{C}$ & areia fina & 2.64 & 0.61 & 1.48 & 3.38 & 2.19 & -0.60 & 0.00 & 0.66 & 75.47 & 23.87 & areia \\
\hline $22.1 .92-02 \mathrm{C}$ & areia grossa & 3.86 & 0.65 & 0.51 & 2.69 & 0.60 & -1.65 & 1.71 & 12.78 & 53.87 & 31.65 & areia argilosa \\
\hline $22.1 .92-02 \mathrm{E}$ & areia grossa & 3.80 & 0.69 & 0.57 & 2.63 & 0.46 & -1.57 & 0.51 & 11.60 & 59.77 & 28.11 & areia argilosa \\
\hline $22.1 .92-02 \mathrm{G}$ & areia grossa & 3.82 & 0.58 & 0.51 & 2.88 & 1.03 & -1.63 & 3.36 & 10.84 & 57.18 & 28.63 & areia argilosa \\
\hline $26.3 .92-01 \mathrm{~B}$ & areia grossa & 3.77 & 0.58 & 0.65 & 2.74 & 0.94 & -1.62 & 1.78 & 12.91 & 59.17 & 26.15 & areia argilosa \\
\hline $19.2 .92-01 \mathrm{~B}$ & areia grossa & 3.40 & 0.48 & 1.18 & 2.13 & 1.00 & -1.68 & 0.00 & 16.17 & 63.83 & 20.00 & areia \\
\hline 22.1.92-02B & casc. sust/clastos & 2.51 & 0.20 & 1.79 & 1.45 & 1.52 & -1.56 & 0.56 & 8.49 & 76.32 & 14.63 & areia \\
\hline $13.2 .92-01 \mathrm{~A}$ & casc. sust/clastos & 3.78 & 0.47 & 0.56 & 2.81 & 1.43 & -1.27 & 0.00 & 25.21 & 42.53 & 32.26 & areia argilosa \\
\hline $13.2 .92-02 \mathrm{~B}$ & casc. sust/clastos & 3.79 & 0.25 & 0.51 & 3.69 & 2.91 & -1.39 & 18.97 & 5.13 & 48.44 & 27.47 & areia argilosa \\
\hline $26.3 .92-03 \mathrm{~A}$ & casc. sust/matriz & 3.94 & 0.45 & 0.50 & 2.95 & 1.47 & -1.66 & 10.27 & 16.41 & 46.46 & 26.86 & areia argilosa \\
\hline $26.3 .92-03 \mathrm{~F}$ & casc. sust/matriz & 3.53 & 0.48 & 0.73 & 3.29 & 1.81 & -1.57 & 8.53 & 5.51 & 62.85 & 23.10 & areia síltica \\
\hline $26.3 .92-03 \mathrm{~B}$ & finos & 1.74 & -0.55 & 2.33 & 7.94 & 8.31 & 0.56 & 0.00 & 0.00 & 9.09 & 90.91 & argila siltica \\
\hline $26.3 .92-01 \mathrm{~A}$ & finos & 2.34 & -0.67 & 1.47 & 7.19 & 8.10 & -1.01 & 0.00 & 1.06 & 13.24 & 85.70 & argila síltica \\
\hline $22.1 .92-02 \mathrm{D}$ & finos & 2.15 & -0.65 & 1.27 & 7.19 & 8.20 & -0.05 & 0.00 & 0.00 & 12.14 & 87.86 & argila síltica \\
\hline $22.1 .92-02 \mathrm{~A}$ & lama & $\longdiv { 3 . 7 3 }$ & -0.79 & 0.65 & 5.75 & 8.13 & -1.52 & 0.00 & 3.75 & 26.64 & 69.60 & argila arenosa \\
\hline $22.1 .92-02 \mathrm{~F}$ & lama & 2.40 & -0.67 & 0.66 & 6.80 & 8.11 & 1.08 & 0.00 & 0.00 & 23.24 & 76.76 & argila arenosa \\
\hline $26.3 .92-03 \mathrm{E}$ & lama & 2.41 & 0.00 & 0.61 & 5.63 & 5.60 & 1.05 & 0.00 & 0.07 & 32.20 & 67.73 & silte argilo arenoso \\
\hline $13.2 .92-01 \mathrm{E}$ & lama & 2.32 & -0.20 & 0.61 & 6.06 & 6.43 & 1.22 & 0.00 & 0.00 & 27.49 & 72.51 & silte argilo arenoso \\
\hline $26.3 .92-02 \mathrm{~B}$ & lama & 3.33 & -0.61 & 0.72 & 5.76 & 7.27 & -1.12 & 0.00 & 2.87 & 29.08 & 68.05 & argila síltico arenosa \\
\hline $13.2 .92-02 \mathrm{~A}$ & lama & 3.36 & -0.68 & 1.01 & 5.95 & 7.62 & -1.16 & 0.00 & 4.50 & 18.22 & 77.28 & argila síltica \\
\hline
\end{tabular}




\begin{tabular}{|l|l|l|l|l|l|l|l|l|l|l|l|l|}
\hline $13.2 .92-01 \mathrm{~B}$ & lama & 3.40 & -0.66 & 0.70 & 5.73 & 7.45 & -1.12 & 0.00 & 2.83 & 27.46 & 69.70 & argila sítico arenosa \\
\hline $26.3 .92-03 \mathrm{C}$ & lama & 2.39 & -0.12 & 0.58 & 5.82 & 6.06 & 1.12 & 0.00 & 0.00 & 32.47 & 67.52 & silte argilo arenoso \\
\hline MÉDIA & & 3.14 & 0.09 & 0.93 & 4.28 & 3.90 & -0.87 & 1.83 & 5.91 & 45.87 & 46.38 & 99.99 \\
\hline
\end{tabular}

Tabela 1C: Relação de amostras do leque aluvial Colônia Pereira e resultados das análises granulométricas

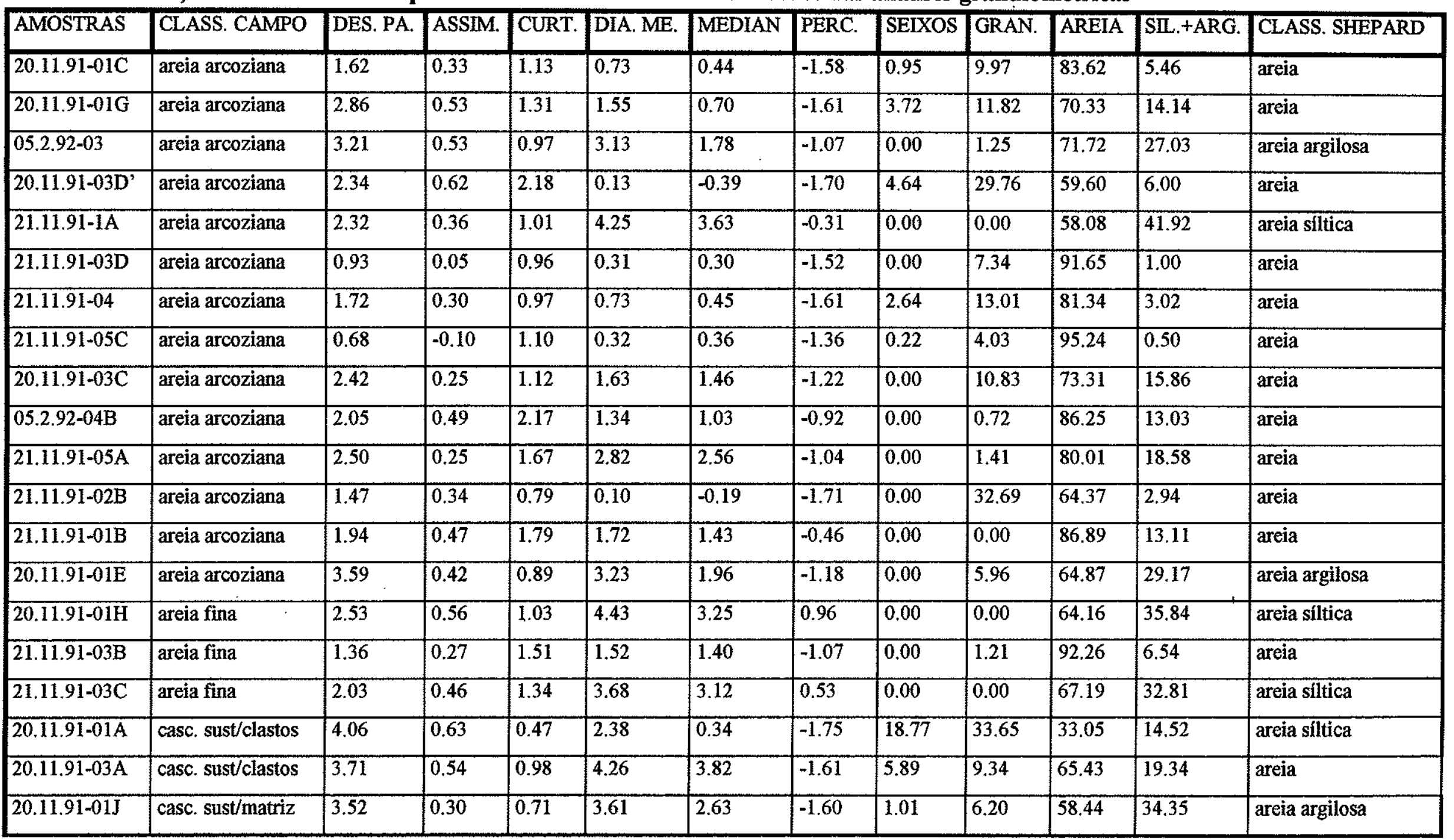




\begin{tabular}{|l|l|l|l|l|l|l|l|l|l|l|l|l|}
\hline $20.11 .91-03 \mathrm{~B}$ & casc. sust/matriz & 3.43 & 0.11 & 0.62 & 4.26 & 3.82 & -1.61 & 4.46 & 4.93 & 45.99 & 44.62 & areia síltica \\
\hline $20.11 .91-01 \mathrm{D}$ & finos & 1.40 & 0.31 & 1.45 & 5.34 & 5.05 & 1.65 & 0.00 & 0.00 & 8.16 & 91.84 & silte \\
\hline $20.11 .91-01 \mathrm{~B}$ & lama & 3.43 & 0.27 & 0.56 & 4.19 & 3.37 & -1.12 & 16.80 & 1.21 & 53.65 & 28.34 & areia argilosa \\
\hline $21.11 .91-03 \mathrm{~A}$ & lama & 2.07 & -0.15 & 0.67 & 6.46 & 6.68 & 2.08 & 0.00 & 0.00 & 15.29 & 84.72 & silte argiloso \\
\hline $21.11 .91-05 \mathrm{~B}$ & lama & 2.48 & 0.29 & 0.59 & 5.18 & 4.55 & 1.33 & 0.00 & 0.00 & 42.84 & 57.16 & areia síltica \\
\hline $21.11 .91-02 \mathrm{C}$ & lama & 2.22 & 0.21 & 0.86 & 5.38 & 4.95 & 1.09 & 0.00 & 0.00 & 27.08 & 72.93 & silte arenoso \\
\hline $05.2 .92-04 \mathrm{~A}$ & lama & 3.12 & 0.20 & 0.59 & 4.61 & 4.01 & -0.87 & 0.00 & 0.84 & 49.02 & 50.14 & areia argilosa \\
\hline $20.11 .91-01 \mathrm{~F}$ & lama & 2.19 & 0.18 & 0.80 & 5.43 & 5.13 & 0.98 & 0.00 & 0.00 & 26.02 & 73.97 & silte arenoso \\
\hline $21.11 .91-02 \mathrm{~A}$ & lama & 1.96 & 0.39 & 0.79 & 5.52 & 4.87 & 2.38 & 0.00 & 0.00 & 22.03 & 77.97 & silte arenoso \\
\hline $21.11 .91-01 \mathrm{C}$ & lama & 2.18 & 0.43 & 0.71 & 5.32 & 4.54 & -1.61 & 0.00 & 2.89 & 37.46 & 59.65 & silte arenoso \\
\hline MEDIA & & 2.38 & 0.32 & 1.07 & 3.04 & 2.50 & -0.55 & 2.04 & 6.42 & 59.93 & 31.62 & 100.01 \\
\hline
\end{tabular}

Tabela 1D: Relação de amostras do leque aluvial Cambará e resultados das análises granulométricas

\begin{tabular}{|l|l|l|l|l|l|l|l|l|l|l|l|l|}
\hline AMOSTRAS & CLASS. CAMPO & DES. PA & ASSIM. & CURT. & DIA. ME. & MEDIAN & PERC. & SEIXOS & GRAN. & AREIA & SIL.+ARG. & CLASS. SHEPARD \\
\hline $23.1 .92 .-02 \mathrm{D}$ & areia arcoziana & 2.14 & 0.07 & 1.56 & 3.14 & 3.11 & -0.99 & 0.00 & 0.98 & 70.03 & 28.98 & areia siltica \\
\hline $23.1 .92-02 \mathrm{~A}$ & areia arcoziana & 2.70 & 0.51 & 1.36 & 2.10 & 1.27 & -1.29 & 0.00 & 3.12 & 78.26 & 18.62 & areia \\
\hline $23.1 .92-02 \mathrm{C}$ & areia arcoziana & 2.08 & 0.46 & 1.43 & 0.57 & 0.26 & -1.25 & 0.00 & 16.41 & 75.68 & 7.92 & areia \\
\hline $12.2 .92-04 \mathrm{~A}$ & areia arcoziana & 2.57 & 0.54 & 1.47 & 1.14 & 0.47 & -1.59 & 0.00 & 10.66 & 74.22 & 15.12 & areia \\
\hline $12.2 .92-03 \mathrm{~B}$ & areia fina & 2.20 & 0.56 & 0.81 & 4.97 & 3.99 & 1.78 & 0.00 & 0.00 & 50.40 & 49.59 & areia síltica \\
\hline $12.2 .92-03 \mathrm{~A}$ & areia fina & 1.39 & 0.39 & 1.12 & 1.69 & 1.45 & -0.19 & 0.00 & 0.00 & 91.62 & 8.39 & areia \\
\hline $12.2 .92-03 \mathrm{C}$ & areia grossa & 2.39 & 0.58 & 1.56 & 0.90 & 0.29 & -1.22 & 0.00 & 10.71 & 75.45 & 13.84 & areia \\
\hline $12.2 .92-05 \mathrm{~B}$ & areia grossa & 0.66 & -0.02 & 1.02 & 1.33 & 1.37 & -0.01 & 0.00 & 0.00 & 99.00 & 1.00 & areia \\
\hline $12.2 .92-04 \mathrm{C}$ & areia grossa & 2.09 & 0.38 & 1.73 & 1.10 & 0.83 & -1.20 & 0.00 & 8.29 & 79.51 & 12.20 & areia \\
\hline $06.2 .92-03$ & casc. sust/clastos & 3.74 & 0.33 & 0.59 & 3.40 & 2.28 & -1.67 & 0.59 & 6.04 & 58.71 & 34.67 & areia argilosa \\
\hline $23.1 .92-01$ & casc. sust/matriz & 3.41 & 0.28 & 0.69 & 3.87 & 3.02 & -1.60 & 5.47 & 3.71 & 55.57 & 35.24 & areia síltica \\
\hline $22.11 .91-01 \mathrm{~A}$ & casc. sust/matriz & 2.06 & 0.41 & 1.25 & 0.83 & 0.48 & -1.59 & 0.00 & 12.51 & 79.43 & 8.06 & areia \\
\hline
\end{tabular}




\begin{tabular}{|l|l|l|l|l|l|l|l|l|l|l|l|l|}
\hline $23.1 .92-02 \mathrm{E}$ & lama & 3.10 & 0.02 & 0.66 & 4.98 & 4.78 & -0.75 & 0.00 & 0.52 & 43.60 & 55.88 & areia argilosa \\
\hline $23.1 .92-02 \mathrm{~B}$ & lama & 3.00 & -0.29 & 0.80 & 5.59 & 6.12 & -1.06 & 0.00 & 1.66 & 26.61 & 71.74 & silte argilo arenoso \\
\hline $12.2 .92-04 \mathrm{~B}$ & lama & 2.32 & -0.30 & 0.57 & 6.18 & 6.78 & 1.86 & 0.00 & 0.00 & 31.05 & 68.95 & argila síltico arenosa \\
\hline MÉDIA & & 2.40 & 0.30 & 1.15 & 2.54 & 2.12 & -0.90 & 0.43 & 5.33 & 68.44 & 25.8 & 100 \\
\hline
\end{tabular}

Tabela 1E: Relação de amostras do leque aluvial Cachoeirinha e resultados das análises granulométricas

\begin{tabular}{|l|l|l|l|l|l|l|l|l|l|l|l|l|}
\hline AMOSTRAS & CLASS. CAMPO & DES. PA. & ASSIM. & CURT. & DIA. ME. & MEDIAN & PERC. & SEIXOS & GRAN. & AREIA & SLL, ARG. & CLASS. SHEPARD \\
\hline $0.6 .2 .92-01$ & areia arcoziana & 2.98 & 0.19 & 0.85 & 4.49 & 3.92 & -0.60 & 0.00 & 0.38 & 51.04 & 48.58 \\
\hline $06.2 .92-02$ & areia arcoziana & 3.24 & 0.46 & 0.90 & 3.60 & 2.38 & -0.64 & 0.00 & 0.23 & 71.42 & 28.34 \\
\hline $12.2 .92-01 \mathrm{t}$ & areia fina & 1.70 & 0.39 & 1.63 & 2.36 & 2.15 & 0.19 & 0.00 & 0.00 & 85.89 & 14.11 & areia síltica argilosa \\
\hline $12.2 .92-02 \mathrm{~A}$ & areia fina & 1.76 & 0.48 & 1.96 & 3.09 & 2.74 & 0.81 & 0.00 & 0.16 & 81.20 & 18.63 & areia \\
\hline $12.2 .92-02 \mathrm{~B}$ & areia fina & 2.05 & 0.58 & 1.09 & 4.45 & 3.59 & 1.68 & 0.00 & 0.00 & 61.32 & 38.68 & areia síltica \\
\hline $12.2 .92-01 \mathrm{~b}$ & areia grossa & 1.26 & 0.18 & 1.09 & -0.06 & -0.10 & -1.72 & 0.00 & 23.24 & 73.82 & 2.93 & areia \\
\hline $12.2 .92-02 \mathrm{C}$ & areia grossa & 0.98 & 0.19 & 1.52 & 1.07 & 1.05 & -0.77 & 0.00 & 0.45 & 94.68 & 4.87 & areia \\
\hline $23.1 .92-01$ & casc. sust/matriz & 3.41 & 0.28 & 0.70 & 3.85 & 2.98 & -1.60 & 4.48 & 3.77 & 56.14 & 35.61 & areia síltica \\
\hline $0.5 .2 .92-02$ & casc. sust/matriz & 2.83 & 0.27 & 1.13 & 2.71 & 2.26 & -1.56 & 2.58 & 5.13 & 68.31 & 23.98 & areia síltica \\
\hline MEDIA & & 2.25 & 0.34 & 1.21 & 2.84 & 2.33 & -0.47 & 0.78 & 3.71 & 71.54 & 23.97 & 100 \\
\hline
\end{tabular}

Tabela 1F: Relação de amostras do leque aluvial Morretes e resultados das análises granulométricas

\begin{tabular}{|l|l|l|l|l|l|l|l|l|l|l|l|l|}
\hline AMOSTRAS & CLASS. CAMPO & DES. PA. & ASSIM. & CURT. & DIA. ME. & MEDIAN & PERC. & SEIXOS & GRAN. & AREIA & SIL.+ARG. & CLASS. SHEPARD \\
\hline $21.12 .92-01 \mathrm{a}$ & areia grossa & 2.77 & 0.46 & 1.44 & 2.77 & 1.92 & -1.12 & 0.00 & 2.89 & 73.06 & 24.06 & areia \\
\hline $11.2 .92-01$ & casc. sust/clastos & 3.68 & 0.68 & 0.52 & 3.00 & 0.84 & -1.62 & 24.89 & 5.91 & 66.28 & 2.91 & areia \\
\hline $21.1 .92-01$ & casc. sust/clastos & 3.76 & 0.68 & 0.98 & 2.53 & 0.43 & -1.60 & 14.79 & 13.33 & 63.34 & 8.54 & areia \\
\hline $20.2 .92-05$ & casc. sust/matriz & 3.52 & -0.25 & 0.56 & 4.97 & 5.93 & -1.59 & 7.68 & 3.20 & 44.03 & 45.09 & areia argilosa \\
\hline MÉDIA & & 3.43 & 0.39 & 0.88 & 3.32 & 2.28 & -1.48 & 11.84 & 6.33 & 61.68 & 20.15 & 100 \\
\hline
\end{tabular}


Tabela 1G: Relação de amostras do leque aluvial Cubatão e resultados das análises granulométricas

\begin{tabular}{|l|l|l|l|l|l|l|l|l|l|l|l|l|}
\hline AMOSTRAS & CLASS. CAMPO & DES. PA. & ASSIM. & CURT. & DIA. ME. & MEDIAN & PERC. & SEIXOS & GRAN. & AREIA & SL.+ARG. & CLASS. SHEPARD \\
\hline $10.3 .92-02 \mathrm{~B}$ & areia arcoziana & 1.46 & 0.50 & 1.69 & 1.72 & 1.48 & 0.10 & 0.00 & 0.00 & 90.25 & 9.75 & areia \\
\hline $10.3 .92-04 \mathrm{C}$ & areia arcoziana & 1.58 & 0.60 & 2.42 & 1.54 & 1.21 & 0.05 & 0.00 & 0.00 & 89.57 & 10.43 & areia \\
\hline $10.3 .92-01 \mathrm{~B}$ & areia fina & 1.63 & 0.53 & 1.22 & 4.22 & 3.74 & 1.74 & 0.00 & 0.00 & 58.78 & 41.22 & areia siltica \\
\hline $10.3 .92-02 \mathrm{~A}$ & areia fina & 3.77 & 0.68 & 1.30 & 2.64 & 0.49 & -1.65 & 17.56 & 9.71 & 67.91 & 4.82 & areia \\
\hline $10.3 .92-03 \mathrm{~A}$ & areia fina & 1.08 & 0.16 & 2.10 & 2.63 & 2.66 & 0.79 & 0.00 & 0.00 & 91.30 & 8.70 & areia \\
\hline $10.3 .92-04 \mathrm{~B}$ & areia grossa & 1.91 & 0.62 & 2.70 & 1.04 & 0.63 & -0.77 & 0.00 & 0.28 & 89.61 & 10.10 & areia \\
\hline $10.3 .92-04 \mathrm{~A}$ & casc. sust/matriz & 1.64 & 0.41 & 1.66 & 0.45 & 0.25 & -1.55 & 0.00 & 8.21 & 85.72 & 6.08 & areia \\
\hline $10.3 .92-01 \mathrm{~A}$ & lama & 2.52 & -0.07 & 0.74 & 5.43 & 5.48 & -0.39 & 0.00 & 0.34 & 33.25 & 66.41 & silte arenoso \\
\hline MÉDIA & & 1.95 & 0.43 & 1.73 & 2.46 & 1.99 & -0.21 & 2.19 & 2.32 & 75.80 & 19.69 & 100 \\
\hline
\end{tabular}

Tabela 1H: Relação de amostras do leque aluvial Brejatuba e resultados das análises granulométricas

\begin{tabular}{|l|l|l|l|l|l|l|l|l|l|l|l|l|}
\hline AMOSTRAS & CLASS. CAMPO & DES. PA. & ASSIM. & CURT. & DIA. ME. & MEDIAN & PERC. & SEIXOS & GRAN. & AREIA & SIL.+ARG. & CLASS. SHEPARD \\
\hline $06.11 .91-02 \mathrm{~A}$ & areia arcoziana & 3.34 & 0.24 & 0.75 & 3.50 & 2.83 & -1.51 & 0.48 & 3.93 & 58.16 & 37.43 & areia síltica \\
\hline $06.11 .91-02 \mathrm{C}$ & areia arcoziana & 2.57 & 0.43 & 0.59 & 4.77 & 3.86 & 1.15 & 0.00 & 0.00 & 50.56 & 49.44 & areia síltica \\
\hline $06.11 .91-02 \mathrm{D}$ & areia arcoziana & 3.14 & 0.32 & 0.77 & 3.21 & 2.48 & -1.07 & 0.00 & 1.82 & 61.39 & 36.80 & areia siltica \\
\hline $06.11 .91-02 \mathrm{~B}$ & areia arcoziana & 2.98 & 0.37 & 0.80 & 2.79 & 2.08 & -1.11 & 0.00 & 2.57 & 67.58 & 29.85 & areia síltica \\
\hline $06.11 .91-01 \mathrm{~A}$ & areia grossa & 3.84 & 0.48 & 0.93 & 2.69 & 1.18 & -1.70 & 0.00 & 19.10 & 56.03 & 24.87 & 1 \\
\hline $06.11 .91-01 \mathrm{~B}$ & areia grossa & 1.06 & 0.18 & 1.24 & 2.41 & 2.36 & 0.56 & 0.00 & 0.00 & 90.53 & 9.47 & areia argilosa \\
\hline $12.11 .91-02$ & casc. sust/matriz & 3.71 & 0.30 & 0.54 & 3.63 & 2.67 & -1.44 & 3.91 & 6.59 & 54.01 & 35.49 & areia argilosa \\
\hline $12.11 .91-01$ & casc. sust/matriz & 3.54 & -0.17 & 0.65 & 4.94 & 5.20 & -1.64 & 5.75 & 8.22 & 37.29 & 48.74 & argila arenosa \\
\hline $12.11 .91-03$ & casc. sust/matriz & 3.35 & 0.35 & 0.79 & 3.76 & 2.65 & -1.63 & 9.95 & 4.76 & 63.46 & 21.83 & areia síltica \\
\hline $13.11 .91-01$ & casc. sust/matriz & 3.45 & -0.77 & 0.63 & 5.96 & 8.05 & -1.33 & 7.43 & 2.50 & 32.77 & 57.29 & argila arenosa \\
\hline $06.11 .91-03$ & casc. sust/matriz & 3.10 & 0.22 & 0.64 & 4.31 & 3.67 & -1.60 & 6.72 & 2.67 & 49.90 & 40.70 & areia síltica \\
\hline
\end{tabular}


Tabela 1I: Relação de amostras do leque aluvial Pombas e resultados das análises granulométricas

\begin{tabular}{|c|c|c|c|c|c|c|c|c|c|c|c|c|}
\hline AMOSTRAS & CLASS. CAMPO & DES. PA. & ASSIM. & CURT. & DIA. ME. & MEDIAN & PERC. & SEIXOS & GRAN. & AREIA & SUl.+ARG. & CLASS. SHEPARD \\
\hline $13.11 .91-03$ & areia arcoziana & 3.58 & 0.21 & 0.56 & 3.93 & 3.25 & -1.62 & 0.58 & 3.75 & 52.58 & 43.08 & areia argilosa \\
\hline $13.11 .91-04$ & lama & 3.43 & 0.09 & 0.59 & 4.49 & 4.13 & -1.09 & 0.00 & 2.15 & 47.30 & 50.55 & areia argilosa \\
\hline
\end{tabular}

Tabela 1J: Relação de amostras do leque aluvial Caovi e resultados das análises granulométricas

\begin{tabular}{|l|l|l|l|l|l|l|l|l|l|l|l|l|}
\hline AMOSTRAS & CLASS. CAMPO & DES. PA. & ASSIM. & CURT. & DIA. ME. & MEDIAN & PERC. & SEIXOS & GRAN. & AREIA & SIL.+ARG. & CLASS. SHEPARD \\
\hline $11.3 .92-03$ & casc. sust/matriz & 3.25 & -0.04 & 0.61 & 4.56 & 4.62 & -1.43 & 0.69 & 2.35 & 43.38 & 53.58 & areia siltica \\
\hline $11.3 .92-01$ & lama & 3.58 & -0.48 & 0.59 & 5.21 & 6.59 & -1.24 & 0.00 & 2.59 & 32.25 & 65.16 & argila arenosa \\
\hline $11.3 .92-02$ & lama & 3.86 & -0.25 & 0.57 & 4.11 & 4.93 & -1.68 & 3.93 & 14.63 & 26.61 & 54.84 & silte arenoso \\
\hline MEDIA & & 3.56 & -0.26 & 0.59 & 4.63 & 5.38 & -1.45 & 1.54 & 6.52 & 34.08 & 57.86 & 100 \\
\hline
\end{tabular}

Tabela 1L: Relação de amostras do leque aluvial Miranda e resultados das análises granulométricas

\begin{tabular}{|l|l|l|l|l|l|l|l|l|l|l|l|l|}
\hline AMOSTRAS & CLASS. CAMPO & DES. PA. & ASSIM. & CURT. & DIA. ME. & MEDIAN & PERC. & SEIXOS & GRAN. & AREIA & SIL.+ARG. & CLASS. SHEPARD \\
\hline $25.9 .91-01 B$ & areia arcoziana & 3.93 & 0.23 & 0.52 & 3.42 & 2.66 & -1.67 & 18.16 & 13.72 & 45.94 & 22.17 & areia argilosa \\
\hline $25.9 .91-01 A$ & lama & 3.44 & -0.06 & 0.62 & 4.82 & 4.83 & -1.13 & 0.00 & 3.38 & 43.84 & 52.78 & areia argilosa \\
\hline MEDIA & & 3.69 & 0.09 & 0.57 & 4.12 & 3.75 & -1.40 & 9.08 & 8.55 & 44.89 & 37.48 & 100 \\
\hline
\end{tabular}




\section{ANEXO 2 - ANÁLISES PALINOLÓGICAS}

Abreviações das tabelas:

ESP. - espécie.

Cont. - número de palinomorfos contados.

\%/soma - porcentagem da espécie de palinomorfo em relação à soma total de todos os palinomorfos. 
Tabela 2A: Análises palinológicas de amostras do leque aluvial Colônia Pereira (Polens + Pteridofitas)

\begin{tabular}{|c|c|c|c|c|c|c|c|}
\hline & & \multicolumn{6}{|c|}{ AMOSTRAS } \\
\hline FAMÍLIAS & \multirow[t]{2}{*}{ GENERO/ESP. } & \multicolumn{2}{|c|}{$21.11 .91-01 \mathrm{C}$} & \multicolumn{2}{|c|}{$21.11 .91-02 \mathrm{C}$} & \multicolumn{2}{|c|}{$20.11 .91-01 \mathrm{~F}$} \\
\hline & & Cont. & $\% /$ soma & Cont. & $\% /$ soma & Cont. & $\% /$ soma \\
\hline Amaranthaceae & Gomphrena & & $0,00 \%$ & 1 & $0,41 \%$ & & $0,00 \%$ \\
\hline \multirow[t]{4}{*}{ Anacardiaceae } & Astronium & 3 & $1,23 \%$ & 6 & $2,44 \%$ & & $0,00 \%$ \\
\hline & Lithraea & 4 & $1,64 \%$ & & $0,00 \%$ & 1 & $0,47 \%$ \\
\hline & Schinus & & $0,00 \%$ & 5 & $2,03 \%$ & & $0,00 \%$ \\
\hline & Tapirira & 3 & $1,23 \%$ & 1 & $0,41 \%$ & 1 & $0,47 \%$ \\
\hline \multirow[t]{2}{*}{ Apocynaceae } & tipo 1 & & $0,00 \%$ & 5 & $2,03 \%$ & & $0,00 \%$ \\
\hline & Mandevilla & 1 & $0,41 \%$ & & $0,00 \%$ & 5 & $2,35 \%$ \\
\hline Aquifoliaceae & Ilex paraguaiensis & 1 & $0,41 \%$ & 1 & $0,41 \%$ & 1 & $0,47 \%$ \\
\hline Araceae & & & $0,00 \%$ & 3 & $1,22 \%$ & & $0,00 \%$ \\
\hline Araliaceae & Didymopanax & & $0,00 \%$ & 2 & $0,81 \%$ & & $0,00 \%$ \\
\hline Araucariaceae & Araucaria & 2 & $0,82 \%$ & 4 & $1,63 \%$ & 8 & $3,76 \%$ \\
\hline Aristolochiaceae & Aristolochia & 2 & $0,82 \%$ & 2 & $0,81 \%$ & & $0,00 \%$ \\
\hline Bignoniaceae & & 1 & $0,41 \%$ & & $0,00 \%$ & & $0,00 \%$ \\
\hline \multirow[t]{2}{*}{ Bomobacaceae } & Bomobacopsis & 1 & $0,41 \%$ & & $0,00 \%$ & & $0,00 \%$ \\
\hline & Pseudobombax & 1 & $0,41 \%$ & & $0,00 \%$ & & $0,00 \%$ \\
\hline \multirow[t]{3}{*}{ Boraginaceae } & Cordia & & $0,00 \%$ & 1 & $0,41 \%$ & & $0,00 \%$ \\
\hline & Potagonula americana & & $0,00 \%$ & 1 & $0,41 \%$ & & $0,00 \%$ \\
\hline & Tournefortia membranaceae & & $0,00 \%$ & 3 & $1,22 \%$ & 1 & $0,47 \%$ \\
\hline Cactaceae & Rhipsalis & & $0,00 \%$ & 1 & $0,41 \%$ & 1 & $0,47 \%$ \\
\hline Caryophyllaceae & Spergularia & 1 & $0,41 \%$ & & $0,00 \%$ & 2 & $0,94 \%$ \\
\hline Celastraceae & Maytenus & & $0,00 \%$ & 1 & $0,41 \%$ & & $0,00 \%$ \\
\hline Chloranthaceae & Hedyosmum & & $0,00 \%$ & 2 & $0,81 \%$ & & $0,00 \%$ \\
\hline Commelinaceae & & 1 & $0,41 \%$ & & $0,00 \%$ & & $0,00 \%$ \\
\hline Compositae & tubuliflorae & 1 & $0,41 \%$ & 6 & $2,44 \%$ & 12 & $5,63 \%$ \\
\hline Crassulaceae & Crassula & 13 & $5,33 \%$ & & $0,00 \%$ & 6 & $2,82 \%$ \\
\hline Cyperaceae & & & $0,00 \%$ & 1 & $0,41 \%$ & & $0,00 \%$ \\
\hline Elaeocarpaceae & Sloanea & & $0,00 \%$ & 1 & $0,41 \%$ & & $0,00 \%$ \\
\hline Ericaceae & & & $0,00 \%$ & 1 & $0,41 \%$ & & $0,00 \%$ \\
\hline \multirow[t]{3}{*}{ Euphorbiaceae } & Alchornea & 15 & $6,15 \%$ & 31 & $12.60 \%$ & 23 & $10,80 \%$ \\
\hline & Dalechampia & 1 & $0,41 \%$ & & $0,00 \%$ & & $0,00 \%$ \\
\hline & diversos & 1 & $0,41 \%$ & 1 & $0,41 \%$ & & $0,00 \%$ \\
\hline Flacourtiaceae & & & $0,00 \%$ & 1 & $0,41 \%$ & & $0,00 \%$ \\
\hline Liliaceae & & 1 & $0,41 \%$ & & $0,00 \%$ & & $0,00 \%$ \\
\hline Loranthaceae & Struthanthus & 1 & $0,41 \%$ & 2 & $0,81 \%$ & 1 & $0,47 \%$ \\
\hline
\end{tabular}




\begin{tabular}{|c|c|c|c|c|c|c|c|}
\hline & tipo 1 & 1 & $0,41 \%$ & & $0,00 \%$ & & $0,00 \%$ \\
\hline \multirow[t]{2}{*}{ Malpighiaceae } & Byrsonima & 2 & $0,82 \%$ & 3 & $1,22 \%$ & & $0,00 \%$ \\
\hline & Stigmaphyllon & 2 & $0,82 \%$ & 2 & $0,81 \%$ & 3 & $1,41 \%$ \\
\hline Malvaceae & Sida & & $0,00 \%$ & 1 & $0,41 \%$ & & $0,00 \%$ \\
\hline Marcgraviaceae & Norantea & 2 & $0,82 \%$ & 2 & $0,81 \%$ & 1 & $0,47 \%$ \\
\hline Melastomataceae & & & $0,00 \%$ & 2 & $0,81 \%$ & & $0,00 \%$ \\
\hline \multirow[t]{2}{*}{ Mimosaceae } & Piptadenia & 2 & $0,82 \%$ & 7 & $2,85 \%$ & & $0,00 \%$ \\
\hline & tipo 1 & & $0,00 \%$ & 1 & $0,41 \%$ & & $0,00 \%$ \\
\hline Monociledoneas & Bromeliaceae & 56 & $22,95 \%$ & 15 & $6,10 \%$ & 3 & $1,41 \%$ \\
\hline Moraceae & & 16 & $6,56 \%$ & 1 & $0,41 \%$ & 3 & $1,41 \%$ \\
\hline Myssinaceae & Rapanea & 1 & $0,41 \%$ & 1 & $0,41 \%$ & & $0,00 \%$ \\
\hline \multirow[t]{2}{*}{ Myrtaceae } & Myrceugenia & 18 & $7,38 \%$ & 6 & $2,44 \%$ & 37 & $17,37 \%$ \\
\hline & Myrteola & 5 & $2,05 \%$ & & $0,00 \%$ & 11 & $5,16 \%$ \\
\hline Papilionaceae & & 1 & $0,41 \%$ & 2 & $0,81 \%$ & 1 & $0,47 \%$ \\
\hline Piperaceae & Piper & 2. & $0,82 \%$ & 2 & $0,81 \%$ & 2 & $0,94 \%$ \\
\hline Poaceae & diversos & 4 & $1,64 \%$ & 19 & $7,72 \%$ & 50 & $23,47 \%$ \\
\hline Podocarpaceae & Podocarpus & 1 & $0,41 \%$ & & $0,00 \%$ & & $0,00 \%$ \\
\hline Polemoniaceae & & & $0,00 \%$ & 1 & $0,41 \%$ & & $0,00 \%$ \\
\hline \multirow[t]{2}{*}{ Proteaceae } & Lomacia & & $0,00 \%$ & & $0,00 \%$ & 2 & $0,94 \%$ \\
\hline & tipo 1 & & $0,00 \%$ & & $0,00 \%$ & 1 & $0,47 \%$ \\
\hline \multirow[t]{2}{*}{ Rubiaceae } & tipo 1 & & $0,00 \%$ & 1 & $0,41 \%$ & & $0,00 \%$ \\
\hline & Borreria & 2 & $0,82 \%$ & & $0,00 \%$ & & $0,00 \%$ \\
\hline Sapindaceae & Allophylus & 1 & $0,41 \%$ & 1 & $0,41 \%$ & & $0,00 \%$ \\
\hline Sapotaceae & Pouteria & & $0,00 \%$ & 2 & $0,81 \%$ & & $0,00 \%$ \\
\hline Solanaceae & Nierrembergia & 1. & $0,41 \%$ & & $0,00 \%$ & & $0,00 \%$ \\
\hline Ulmaceae & Trema & 1 & $0,41 \%$ & 1 & $0,41 \%$ & 1 & $0,47 \%$ \\
\hline Umbelliferae & & & $0,00 \%$ & 1 & $0,41 \%$ & & $0,00 \%$ \\
\hline Urticaceae & & 1 & $0,41 \%$ & 1 & $0,41 \%$ & & $0,00 \%$ \\
\hline Briofitas & & & $0,00 \%$ & 1 & $0,41 \%$ & & $0,00 \%$ \\
\hline \multirow[t]{6}{*}{ Pteridofitas } & Monoletes espinhosos & 1 & $0,41 \%$ & 4 & $1,63 \%$ & & $0,00 \%$ \\
\hline & Monoletes lisos & 36 & $14,75 \%$ & 37 & $15,04 \%$ & 8 & $3,76 \%$ \\
\hline & Monoletes pilosos & 1 & $0,41 \%$ & & $0,00 \%$ & & $0,00 \%$ \\
\hline & Monoletes reticulados & 11 & $4,51 \%$ & 1 & $0,41 \%$ & 1 & $0,47 \%$ \\
\hline & Monoletes verrogusos & 7 & $2,87 \%$ & 9 & $3,66 \%$ & 2 & $0,94 \%$ \\
\hline & Monoletes reticulados soltos & 5 & $2,05 \%$ & & $0,00 \%$ & 1 & $0,47 \%$ \\
\hline \multirow[t]{4}{*}{ Total Monoletes } & & 61 & $25,00 \%$ & 51 & $20,73 \%$ & 12 & $5,63 \%$ \\
\hline & Triletes lisos & 3 & $1,23 \%$ & 18 & $7,32 \%$ & 12 & $5,63 \%$ \\
\hline & Triletes granulados & & $0,00 \%$ & & $0,00 \%$ & 3. & $1,41 \%$ \\
\hline & Triletes perfurados & & $0,00 \%$ & 2 & $0,81 \%$ & 21 & $0,94 \%$ \\
\hline
\end{tabular}




\begin{tabular}{|l|l|r|r|r|r|r|r|}
\hline & Triletes pilados & & $0,00 \%$ & 1 & $0,41 \%$ & 4 & $1,88 \%$ \\
\hline & Triletes tipo Pilularia & 2 & $0,82 \%$ & 1 & $0,41 \%$ & & $0,00 \%$ \\
\hline & Triletes reticulados & 1 & $0,41 \%$ & 3 & $1,22 \%$ & 1 & $0,47 \%$ \\
\hline & Triletes scabrosos & & $0,00 \%$ & 2 & $0,81 \%$ & & $0,00 \%$ \\
\hline & Triletes verrugosos & 4 & $1,64 \%$ & 12 & $4,88 \%$ & 2 & $0,94 \%$ \\
\hline Total Triletes & & 10 & $4,10 \%$ & 39 & $15,85 \%$ & 24 & $11,27 \%$ \\
\hline Total Pteridofitas & & 71 & $29,10 \%$ & 90 & $36,59 \%$ & 36 & $16,90 \%$ \\
\hline Fungi & diversos & 224 & $91,80 \%$ & 3993 & $1623 \%$ & 4047 & $1900 \%$ \\
\hline Algas & Coelastrum & & $0,00 \%$ & 1 & $0,41 \%$ & & $0,00 \%$ \\
\hline & Spirogyra & & $0,00 \%$ & 1 & $0,41 \%$ & & $0,00 \%$ \\
\hline & Zygnema & & $0,00 \%$ & 1 & $0,41 \%$ & & $0,00 \%$ \\
\hline Plathelminthes & Ovos & & $0,00 \%$ & 2 & $0,81 \%$ & 2 & $0,94 \%$ \\
\hline & & & & & & & \\
\hline Soma polínica & Polens + Pteridofitas & 244 & & 246 & & 213 & \\
\hline
\end{tabular}


Tabela 2B: Análises palinológicas de amostras do leque aluvial Colônia Pereira (Polens)

\begin{tabular}{|c|c|c|c|c|c|c|c|}
\hline & & \multicolumn{6}{|c|}{ AMOSTRAS } \\
\hline FAMÍLIAS & \multirow[t]{2}{*}{ GÊNERO/ESP. } & \multicolumn{2}{|c|}{$21.11 .91-01 \mathrm{C}$} & \multicolumn{2}{|c|}{$21.11 .91-02 \mathrm{C}$} & \multicolumn{2}{|c|}{$20.11 .91-01 \mathrm{~F}$} \\
\hline & & Cont. & $\% /$ soma & Cont. & $\% /$ soma & Cont. & $\% /$ soma \\
\hline Amaranthaceae & Gomphrena & & $0,00 \%$ & 1 & $0,65 \%$ & & $0,00 \%$ \\
\hline \multirow[t]{4}{*}{ Anacardiaceae } & Astronium & 3 & $1,73 \%$ & 6 & $3,87 \%$ & & $0,00 \%$ \\
\hline & Lithraea & 4 & $2,31 \%$ & & $0,00 \%$ & 1 & $0,56 \%$ \\
\hline & Schinus & & $0,00 \%$ & 5 & $3,23 \%$ & & $0,00 \%$ \\
\hline & Tapirira & 3 & $1,73 \%$ & 1 & $0,65 \%$ & 1 & $0,56 \%$ \\
\hline \multirow[t]{2}{*}{ Apocynaceae } & tipo 1 & & $0,00 \%$ & 5 & $3,23 \%$ & & $0,00 \%$ \\
\hline & Mandevilla & 1 & $0,58 \%$ & & $0,00 \%$ & 5 & $2,82 \%$ \\
\hline Aquifoliaceae & Ilex paraguaiensis & 1 & $0,58 \%$ & 1 & $0,65 \%$ & 1 & $0,56 \%$ \\
\hline Araceae & & & $0,00 \%$ & 3 & $1,94 \%$ & & $0,00 \%$ \\
\hline Araliaceae & Didymopanax & & $0,00 \%$ & 2 & $1,29 \%$ & & $0,00 \%$ \\
\hline Araucariaceae & Araucaria & 2 & $1,16 \%$ & 4 & $2,58 \%$ & 8 & $4,52 \%$ \\
\hline Aristolochiaceae & Aristolochia & 2 & $1,16 \%$ & 2 & $1,29 \%$ & & $0,00 \%$ \\
\hline Bignoniaceae & & 1 & $0,58 \%$ & & $0,00 \%$ & & $0,00 \%$ \\
\hline \multirow[t]{2}{*}{ Bomobacaceae } & Bomobacopsis & 1 & $0,58 \%$ & & $0,00 \%$ & & $0,00 \%$ \\
\hline & Pseudobombax & 1 & $0,58 \%$ & & $0,00 \%$ & & $0,00 \%$ \\
\hline \multirow[t]{3}{*}{ Boraginaceae } & Cordia & & $0,00 \%$ & 1 & $0,65 \%$ & & $0,00 \%$ \\
\hline & Potagonula americana & & $0,00 \%$ & 1 & $0,65 \%$ & & $0,00 \%$ \\
\hline & Tournefortia membranaceae & & $0,00 \%$ & 3 & $1,94 \%$ & 1 & $0,56 \%$ \\
\hline Cactaceae & Rhipsalis & & $0,00 \%$ & 1 & $0,65 \%$ & 1 & $0,56 \%$ \\
\hline Caryophyllaceae & Spergularia & 1 & $0,58 \%$ & & $0,00 \%$ & 2 & $1,13 \%$ \\
\hline Celastraceae & Maytenus & & $0,00 \%$ & 1 & $0,65 \%$ & & $0,00 \%$ \\
\hline Chloranthaceae & Hedyosmum & & $0,00 \%$ & 2 & $1,29 \%$ & & $0,00 \%$ \\
\hline Commelinaceae & & 1 & $0,58 \%$ & & $0,00 \%$ & & $0,00 \%$ \\
\hline Compositae & tubuliflorae & 1 & $0,58 \%$ & 6 & $3,87 \%$ & 12 & $6,78 \%$ \\
\hline Crassulaceae & Crassula & 13 & $7,51 \%$ & & $0,00 \%$ & 6 & $3,39 \%$ \\
\hline Cyperaceae & & & $0,00 \%$ & 1 & $0,65 \%$ & & $0,00 \%$ \\
\hline Elaeocarpaceae & Sloanea & & $0,00 \%$ & 1 & $0,65 \%$ & & $0,00 \%$ \\
\hline Ericaceae & & & $0,00 \%$ & 1 & $0,65 \%$ & & $0,00 \%$ \\
\hline \multirow[t]{3}{*}{ Euphorbiaceae } & Alchornea & 15 & $8,67 \%$ & 31 & $20,00 \%$ & 23 & $12,99 \%$ \\
\hline & Dalechampia & 1 & $0,58 \%$ & & $0,00 \%$ & & $0,00 \%$ \\
\hline & diversos & 1 & $0,58 \%$ & 1 & $0,65 \%$ & & $0,00 \%$ \\
\hline Flacourtiaceae & & & $0,00 \%$ & 1 & $0,65 \%$ & & $0,00 \%$ \\
\hline Liliaceae & & 1 & $0,58 \%$ & & $0,00 \%$ & & $0,00 \%$ \\
\hline
\end{tabular}




\begin{tabular}{|c|c|c|c|c|c|c|c|}
\hline Loranthaceae & Struthanthus & 1 & $0,58 \%$ & 2 & $1,29 \%$ & 1 & $0,56 \%$ \\
\hline & tipo 1 & 1 & $0,58 \%$ & & $0,00 \%$ & & $0,00 \%$ \\
\hline \multirow[t]{2}{*}{ Malpighiaceae } & Byrsonima & 2 & $1,16 \%$ & 3 & $1,94 \%$ & & $0,00 \%$ \\
\hline & Stigmaphyllon & 2 & $1,16 \%$ & 2 & $1,29 \%$ & 3 & $1,69 \%$ \\
\hline Malvaceae & Sida & & $0,00 \%$ & 1 & $0,65 \%$ & & $0,00 \%$ \\
\hline Marcgraviaceae & Norantea & 2 & $1,16 \%$ & 2 & $1,29 \%$ & 1 & $0,56 \%$ \\
\hline Melastomataceae & & & $0,00 \%$ & 2. & $1,29 \%$ & & $0,00 \%$ \\
\hline \multirow[t]{2}{*}{ Mimosaceae } & Piptadenia & 2 & $1,16 \%$ & 7 & $4,52 \%$ & & $0,00 \%$ \\
\hline & tipo 1 & & $0,00 \%$ & 1 & $0,65 \%$ & & $0,00 \%$ \\
\hline Monociledoneas & Bromeliaceae & 56 & $32,37 \%$ & 15 & $9,68 \%$ & 3 & $1,69 \%$ \\
\hline Moraceae & & 16 & $9,25 \%$ & 1 & $0,65 \%$ & 3 & $1,69 \%$ \\
\hline Myssinaceae & Rapanea & 1 & $0,58 \%$ & 1 & $0,65 \%$ & & $0,00 \%$ \\
\hline \multirow[t]{2}{*}{ Myrtaceae } & Myrceugenia & 18 & $10,40 \%$ & 6 & $3,87 \%$ & 37 & $20,90 \%$ \\
\hline & Myrteola & 5 & $2,89 \%$ & & $0,00 \%$ & 11 & $6,21 \%$ \\
\hline Papilionaceae & & 1 & $0,58 \%$ & 2 & $1,29 \%$ & 1 & $0,56 \%$ \\
\hline Piperaceae & Piper & 2 & $1,16 \%$ & 2 & $1,29 \%$ & 2 & $1,13 \%$ \\
\hline Poaceae & diversos & 4 & $2,31 \%$ & 19 & $12,26 \%$ & 50 & $28,25 \%$ \\
\hline Podocarpaceae & Podocarpus & 1 & $0,58 \%$ & & $0,00 \%$ & & $0,00 \%$ \\
\hline Polemoniaceae & & & $0,00 \%$ & 1 & $0,65 \%$ & & $0,00 \%$ \\
\hline \multirow[t]{2}{*}{ Proteaceae } & Lomacia & & $0,00 \%$ & & $0,00 \%$ & 2 & $1,13 \%$ \\
\hline & tipo 1 & & $0,00 \%$ & & $0,00 \%$ & 1 & $0,56 \%$ \\
\hline \multirow[t]{2}{*}{ Rubiaceae } & tipo 1 & & $0,00 \%$ & 1 & $0,65 \%$ & & $0,00 \%$ \\
\hline & Borreria & 2 & $1,16 \%$ & & $0,00 \%$ & & $0,00 \%$ \\
\hline Sapindaceae & Allophylus & 1 & $0,58 \%$ & 1 & $0,65 \%$ & & $0,00 \%$ \\
\hline Sapotaceae & Pouteria & & $0,00 \%$ & 2 & $1,29 \%$ & & $0,00 \%$ \\
\hline Solanaceae & Nierrembergia & 1 & $0,58 \%$ & & $0,00 \%$ & & $0,00 \%$ \\
\hline Ulmaceae & Trema & 1 & $0,58 \%$ & 1 & $0,65 \%$ & 1 & $0,56 \%$ \\
\hline Umbelliferae & & & $0,00 \%$ & 1 & $0,65 \%$ & & $0,00 \%$ \\
\hline Urticaceae & & 1 & $0,58 \%$ & 1 & $0,65 \%$ & & $0,00 \%$ \\
\hline Briofitas & & & $0,00 \%$ & 1 & $0,65 \%$ & & $0,00 \%$ \\
\hline \multirow[t]{6}{*}{ Pteridofitas } & Monoletes espinhosos & 1 & $0,58 \%$ & 4 & $2,58 \%$ & & $0,00 \%$ \\
\hline & Monoletes lisos & 36 & $20,81 \%$ & 37 & $23,87 \%$ & 8 & $4,52 \%$ \\
\hline & Monoletes pilosos & 1 & $0,58 \%$ & & $0,00 \%$ & & $0,00 \%$ \\
\hline & Monoletes reticulados & 11 & $6,36 \%$ & 1 & $0,65 \%$ & 1 & $0,56 \%$ \\
\hline & Monoletes verrogusos & 7 & $4,05 \%$ & 9 & $5,81 \%$ & 2 & $1,13 \%$ \\
\hline & Monoletes reticulados soltos & 5 & $2,89 \%$ & & $0,00 \%$ & 1 & $.0,56 \%$ \\
\hline \multirow[t]{3}{*}{ Total Monoletes } & & 61 & $35,26 \%$ & 51 & $32,90 \%$ & 12 & $6,78 \%$ \\
\hline & Triletes lisos & 3 & $1,73 \%$ & 18 & $11,61 \%$ & 12 & $6,78 \%$ \\
\hline & Triletes granulados & & $0,00 \%$ & & $0,00 \%$ & 3 & $1,69 \%$ \\
\hline
\end{tabular}




\begin{tabular}{|l|l|r|r|r|r|r|r|}
\hline & Triletes perfurados & & $0,00 \%$ & 2 & $1,29 \%$ & 2 & $1,13 \%$ \\
\hline & Triletes pilados & & $0,00 \%$ & 1 & $0,65 \%$ & 4 & $2,26 \%$ \\
\hline & Triletes tipo Pilularia & 2 & $1,16 \%$ & 1 & $0,65 \%$ & & $0,00 \%$ \\
\hline & Triletes reticulados & 1 & $0,58 \%$ & 3 & $1,94 \%$ & 1 & $0,56 \%$ \\
\hline & Triletes scabrosos & & $0,00 \%$ & 2 & $1,29 \%$ & & $0,00 \%$ \\
\hline & Triletes verrugosos & 4 & $2,31 \%$ & 12 & $7,74 \%$ & 2 & $1,13 \%$ \\
\hline Total Triletes & & 10 & $5,78 \%$ & 39 & $25,16 \%$ & 24 & $13,56 \%$ \\
\hline Total Pteridofitas & & 71 & $41,04 \%$ & 90 & $58,06 \%$ & 36 & $20,34 \%$ \\
\hline Fungi & diversos & 224 & $129,48 \%$ & 3993 & $2576,1 \%$ & 3363 & $1900,0 \%$ \\
\hline Algas & Coelastrum & & $0,00 \%$ & 1 & $0,65 \%$ & & $0,00 \%$ \\
\hline & Spirogyra & & $0,00 \%$ & 1 & $0,65 \%$ & & $0,00 \%$ \\
\hline & Zygnema & & $0,00 \%$ & 1 & $0,65 \%$ & & $0,00 \%$ \\
\hline Plathelminthes & Ovos & & $0,00 \%$ & 2 & $1,29 \%$ & 2 & $1,13 \%$ \\
\hline & & & & & & & \\
\hline Soma polínica & Somente polens & 173 & & 155 & & 177 & \\
\hline
\end{tabular}




\title{
ANEXO 3 - MEDIDAS DE ORIENTAÇÃO E CARACTERÍSTICAS MORFOSCÓPICAS DOS SEIXOS
}

\author{
Abreviação das tabelas: \\ RUMO DE INCL. - rumo de inclinação. \\ ÂNG. DE INCL. - ângulo de inclinação. \\ MED. DOS EIXOS - medidas dos eixos. \\ ARRED. - arredondamento. \\ ESFER. - esfericidade.
}


Tabela 3A: Medidas de orientação e características morfoscópicas dos seixos da Formação Alexandra - Ponto 13.2.92-01)

\begin{tabular}{|c|c|c|c|c|c|c|c|}
\hline \multirow{2}{*}{$\begin{array}{l}\text { RUMO DE INCL. } \\
\text { Eixo longo (graus) }\end{array}$} & \multirow{2}{*}{$\frac{\text { ÂNG. DE INCL. }}{\text { (graus) }}$} & \multicolumn{3}{|c|}{ MED. DOS EIXOS (cm) } & \multirow{2}{*}{ ARRED. } & \multirow{2}{*}{ ESFER. } & \multirow{2}{*}{ LITOLOGIA } \\
\hline & & $\mathbf{a}$ & b & c & & & \\
\hline 145 & 20 & 13 & 8 & 6,5 & 0,6 & 0,77 & quartzo \\
\hline 157 & 15 & 12 & 11 & 3,5 & 0,7 & $0, \overline{91}$ & quartzo \\
\hline 127 & 10 & 10 & 7,5 & 5,3 & 0,6 & 0,83 & quartzo \\
\hline 63 & 20 & 10,5 & 7,3 & 6,6 & 0,5 & 0,81 & quartzo \\
\hline 87 & 10 & 10 & 9 & 3,7 & 0,4 & 0,77 & quartzo \\
\hline 25 & 10 & 10,5 & 7,5 & 5 & 0,5 & 0,83 & quartzo \\
\hline 198 & 5 & 7 & 5,2 & 2,9 & 0,5 & 0,83 & quartzo \\
\hline 114 & 20 & 10,5 & 9 & 5,5 & 0,6 & 0,87 & quartzo \\
\hline 305 & 8 & 7,9 & 6,5 & 3,7 & 0,7 & 0,85 & quartzo \\
\hline 100 & 18 & 9,5 & 5,3 & 2,2 & 0,5 & 0,77 & quartzo \\
\hline 340 & 2 & 7 & 4,5 & 2,8 & 0,7 & 0,75 & quartzo \\
\hline 46 & 12 & 11,2 & 7 & 4,5 & 0,6 & 0,81 & quartzo \\
\hline 242 & 9 & 10,3 & 5,8 & 3,5 & 0,4 & 0,75 & quartzo \\
\hline 7 & 5 & 10,5 & 7,8 & 3,8 & 0,6 & 0,83 & quartzo \\
\hline 254 & 10 & 13,7 & 11 & 5,5 & 0,6 & 0,85 & quartzo \\
\hline 95 & 8 & 8,7 & 7,3 & 4,5 & 0,5 & 0,89 & quartzo \\
\hline 52 & 12 & 10 & 5,7 & 3,4 & 0,6 & 0,75 & quartzo \\
\hline 343 & 17 & 8 & 7 & 3 & 0,6 & 0,89 & quartzo \\
\hline 218 & 40 & 4,3 & 6 & 7,5 & 0,6 & 0,83 & quartzo \\
\hline 306 & 25 & 6,9 & 5,3 & 2,7 & 0,5 & 0,85 & quartzo \\
\hline 245 & 45 & 10 & 5,5 & 3,2 & 0,4 & 0,79 & quartzo \\
\hline 227 & 8 & 9,8 & 4,2 & 2,7 & 0,6 & 0,77 & quartzo \\
\hline 158 & 15 & 12,5 & 8,7 & 7,5 & 0,6 & 0,81 & quartzo \\
\hline 174 & 5 & 8,5 & 6,3 & 4,5 & 0,5 & 0,83 & quartzo \\
\hline
\end{tabular}


(Cont.)

\begin{tabular}{|c|c|c|c|c|c|c|c|}
\hline \multirow{2}{*}{$\frac{\text { RUMO DE INCL. }}{\text { Eixo longo (graus) }}$} & \multirow{2}{*}{$\frac{\text { ÂNG. DE INCL. }}{\text { (graus) }}$} & \multicolumn{3}{|c|}{ MED. DOS EIXOS (cm) } & \multirow{2}{*}{ ARRED. } & \multirow{2}{*}{ ESFER. } & \multirow{2}{*}{ LITOLOGIA } \\
\hline & & $\mathbf{a}$ & b & c & & & \\
\hline 298 & 15 & 5,9 & 3 & 2,5 & 0,7 & 0,75 & quartzo \\
\hline 46 & 17 & 8,2 & 4,5 & 3,8 & 0,6 & 0,73 & quartzo \\
\hline 350 & 5 & 6,4 & 4,4 & 2 & 0,6 & 0,83 & quartzo \\
\hline 343 & 20 & 11 & 5,8 & 4,7 & 0,6 & 0,73 & quartzo \\
\hline 207 & 2 & 5,1 & 4,2 & 2,8 & 0,5 & 0,89 & quartzo \\
\hline 5 & 9 & 5,2 & 4,3 & 2,5 & 0,5 & 0,83 & quartzo \\
\hline 62 & 2 & 8,8 & 5,5 & 3,9 & 0,5 & 0,81 & quartzo \\
\hline 207 & 25 & 6,2 & 3 & 2,5 & 0,5 & 0,75 & quartzo \\
\hline 347 & 10 & 12 & 6,5 & 3,3 & 0,6 & 0,77 & \\
\hline 340 & 12 & 7,9 & 6,1 & 3,4 & 0,6 & 0,87 & \\
\hline 150 & 5 & 4,2 & 2,6 & 1,5 & 0,5 & 0,71 & \\
\hline 126 & 5 & 5,5 & 4,0 & 2,2 & 0,7 & 0,83 & \\
\hline 45 & 10 & 4,4 & 3,5 & 3 & 0,4 & 0,81 & \\
\hline 102 & 5 & 6,7 & 4,6 & 2,2 & 0,6 & 0,77 & \\
\hline 142 & 2 & 7,9 & 6 & 4 & 0,6 & 0,83 & \\
\hline 226 & 10 & 13,5 & 6,2 & 4,6 & 0,7 & 0,77 & \\
\hline 60 & 12 & 5,6 & 3,7 & 3,3 & 0,6 & 0,81 & \\
\hline 194 & 3 & 8,9 & 7,9 & 3,7 & 0,5 & 0,89 & \\
\hline 173 & 10 & 6,6 & 4 & 2,2 & 0,5 & 0,77 & \\
\hline 40 & 8 & 5,7 & 4,5 & 3,2 & 0,4 & 0,85 & \\
\hline 286 & 9 & 9,5 & 5,5 & 4,4 & 0,3 & 0,79 & \\
\hline 333 & 12 & 10 & 5,5 & 3,5 & 0,5 & 0,73 & \\
\hline 262 & 32 & 6,3 & 4 & 3,3 & 0,4 & 0,79 & \\
\hline 355 & 30 & 6,5 & 5,4 & 4,2 & 0,6 & 0,85 & \\
\hline
\end{tabular}


(Cont.)

\begin{tabular}{|c|c|c|c|c|c|c|c|}
\hline \multirow{2}{*}{$\begin{array}{c}\text { RUMO DE INCL. } \\
\text { Eixo longo (graus) }\end{array}$} & \multirow{2}{*}{\begin{tabular}{|c|} 
ÂNG. DE INCL. \\
(graus)
\end{tabular}} & \multicolumn{3}{|c|}{ MED. DOS EIXOS $(\mathrm{cm})$} & \multirow{2}{*}{ ARRED. } & \multirow[b]{2}{*}{ ESFER } & \multirow[b]{2}{*}{ LITOLOGIA } \\
\hline & & $\mathbf{a}$ & b & c & & & \\
\hline 204 & 25 & 8 & 5,2 & 2,3 & 0,6 & 0,79 & \\
\hline 208 & 30 & 6,3 & 5 & 1,5 & 0,6 & 0,83 & \\
\hline 328 & 9 & 7 & 2 & 1,3 & 0,5 & 0,63 & \\
\hline 157 & 20 & 10,3 & 8,1 & 5,9 & 0,6 & 0,83 & \\
\hline 250 & 9 & 7,8 & 5 & 3 & 0,5 & 0,77 & \\
\hline 103 & 25 & 12 & 6,5 & 3,8 & 0,6 & 0,77 & \\
\hline 312 & 20 & 10,9 & 9 & 7 & 0,4 & 0,83 & \\
\hline 290 & 25 & 5,3 & 3,5 & 1,9 & 0,4 & 0,79 & \\
\hline 332 & 20 & 3,8 & 2,9 & 2,4 & 0,6 & 0,83 & \\
\hline 50 & 6 & 8,4 & 4,6 & 4 & 0,5 & 0,73 & \\
\hline 182 & 20 & 6 & 3,9 & 2,5 & 0,6 & 0,75 & \\
\hline 318 & 10 & 8,8 & 5,4 & 3,7 & 0,5 & 0,77 & \\
\hline 45 & 13 & 10,5 & 5,9 & 3 & 0,6 & 0,73 & \\
\hline 65 & 13 & 8 & 5,7 & 3,2 & 0,5 & 0,79 & \\
\hline 220 & 3 & 7,7 & 6,5 & 4,5 & 0,5 & 0,85 & \\
\hline 280 & 10 & 5 & 3,5 & 1,5 & 0,4 & 0,81 & \\
\hline 184 & 9 & 8,5 & 5,5 & 2,3 & 0,5 & 0,83 & \\
\hline 140 & 3 & 10,6 & 8,5 & 5 & 0,5 & 0,83 & \\
\hline 15 & 20 & 8 & 3,5 & 3,2 & 0,6 & 0,71 & \\
\hline 317 & 8 & 6,5 & 5,5 & 4 & 0,5 & 0,87 & \\
\hline 98 & 20 & 10 & 6,2 & 2,6 & 0,4 & 0,79 & \\
\hline 132 & 7 & 9,5 & 5,3 & 4,2 & 0,3 & 0,71 & \\
\hline 133 & 9 & 5,4 & 4 & 2,8 & 0,7 & 0,85 & \\
\hline 43 & 12 & 6,5 & 4,8 & 2 & 0,6 & 0,81 & \\
\hline 280 & 3 & 5,5 & 2,9 & 1,2 & 0,4 & 0,77 & \\
\hline
\end{tabular}


(Cont.)

\begin{tabular}{|c|c|c|c|c|c|c|c|}
\hline \multirow{2}{*}{\begin{tabular}{|l} 
RUMO DE INCL. \\
Eixo longe (graus)
\end{tabular}} & \multirow{2}{*}{$\frac{\hat{A N G} \text {. DE INCL. }}{\text { (graus) }}$} & \multicolumn{3}{|c|}{ MED. DOS EIXOS (cm) } & \multirow{2}{*}{ ARRED. } & \multirow{2}{*}{ ESFER. } & \multirow{2}{*}{ LITOLOGIA } \\
\hline & & $\mathbf{a}$ & b & c & & & \\
\hline 234 & 3 & 6,3 & 4,4 & 3,2 & 0,5 & 0,83 & \\
\hline 286 & 15 & 7,7 & 4,8 & 2,8 & 0,6 & 0,77 & \\
\hline 328 & 25 & 10 & 8 & 4 & 0,4 & 0,83 & \\
\hline 233 & 25 & 5 & 3,9 & 2,7 & 0,5 & 0,81 & \\
\hline 57 & 3 & 11,3 & 9 & 5 & 0,4 & 0,81 & \\
\hline 49 & 9 & 8,2 & 4,3 & 3,8 & 0,4 & 0,73 & \\
\hline 287 & 13 & 4,5 & 3,8 & 2,7 & 0,5 & 0,83 & \\
\hline 265 & 2 & 10,4 & 7,5 & 5,7 & 0,6 & 0,79 & \\
\hline 268 & 20 & 5,2 & 4 & 3,7 & 0,5 & 0,81 & \\
\hline 22 & 18 & 7,7 & 5,7 & 2,9 & 0,4 & 0,79 & \\
\hline 12 & 9 & 7,8 & 6,2 & 3,5 & 0,5 & 0,87 & \\
\hline 83 & 7 & 9 & 5,5 & 4,8 & 0,4 & 0,77 & \\
\hline 10 & 28 & 6,5 & 4,6 & 3,3 & 0,5 & 0,75 & \\
\hline 79 & 12 & 6,5 & 4 & 2,6 & 0,6 & 0,77 & \\
\hline 89 & 19 & 7,2 & 5 & 3,3 & 0,6 & 0,79 & \\
\hline 53 & 13 & 8,3 & 4,4 & 1,9 & 0,4 & 0,75 & \\
\hline 37 & 20 & 6 & 4,7 & 1,9 & 0,5 & 0,83 & \\
\hline 27 & 10 & 6,2 & 3,9 & 3 & 0,6 & 0,73 & \\
\hline 298 & 7 & 5,4 & 4,5 & 3 & 0,5 & 0,81 & \\
\hline 73 & 17 & 4,2 & 3,3 & 3 & 0,6 & 0,77 & \\
\hline 120 & 7 & 6,7 & 5 & 2 & 0,4 & 0,79 & \\
\hline 50 & 20 & 7,7 & 4,7 & 4 & 0,4 & 0,81 & \\
\hline 180 & 30 & 8,2 & 5 & 4 & 0,5 & 0,79 & \\
\hline 43 & 10 & 10,2 & 6,7 & 5,5 & 0,4 & 0,79 & \\
\hline 55 & 10 & 6,7 & 5,8 & 3,5 & 0,6 & 0,85 & \\
\hline
\end{tabular}


(Cont.)

\begin{tabular}{|c|c|c|c|c|c|c|c|}
\hline RUMO DE INCL. & ÂNG. DE INCL. & \multicolumn{2}{|c|}{ MED. DOS EIXOS (cm) } & \multirow{2}{*}{ ARRED. } & ESFER. & \multirow{2}{*}{ LITOLOGIA } \\
\hline Eixo longo (graus) & (graus) & $\mathbf{a}$ & $\mathbf{b}$ & $\mathbf{c}$ & & & \\
\hline 275 & 25 & 9,5 & 6,7 & 4,3 & 0,4 & 0,79 & \\
\hline 232 & 15 & 8,2 & 6,3 & 2,3 & 0,5 & $0,8 \overline{1}$ & \\
\hline
\end{tabular}

Tabela 3B: Medidas de orientação e características morfoscópicas dos seixos da Formação Alexandra - Ponto 26.3.92-03)

\begin{tabular}{|c|c|c|c|c|c|c|c|}
\hline \multirow{2}{*}{$\begin{array}{l}\text { RUMO DE NCL. } \\
\text { Eixo longo (graus) }\end{array}$} & \multirow{2}{*}{$\frac{\text { ÂNG. DE INCL. }}{\text { (graus) }}$} & \multicolumn{3}{|c|}{ MED. DOS EIXOS (cm) } & \multirow{2}{*}{ ARRED. } & \multirow{2}{*}{ ESFER. } & \multirow{2}{*}{ LITOLOGIA } \\
\hline & & $\mathbf{a}$ & $\mathbf{b}$ & c & & & \\
\hline 83 & 5 & 9 & 6,8 & 5 & 0,5 & 0,83 & \\
\hline 84 & 8 & 8,5 & 4,3 & 2,5 & 0,6 & 0,73 & \\
\hline 85 & 20 & 10,3 & 6 & 5,5 & 0,5 & 0,77 & \\
\hline 240 & 25 & 9,2 & 7,9 & 4,2 & 0,4 & 0,75 & \\
\hline 242 & 19 & 7 & 6 & 3,2 & 0,4 & 0,87 & \\
\hline 28 & 2 & 6 & 3,3 & 2,7 & 0,4 & 0,75 & \\
\hline 343 & 10 & 4,3 & 2,7 & 1,5 & 0,4 & 0,81 & \\
\hline 228 & 12 & 9,2 & 6,3 & 2,4 & 0,5 & 0,77 & \\
\hline 254 & 10 & 6,6 & 5,5 & 3 & 0,6 & 0,83 & \\
\hline 215 & 15 & 8,8 & 5,7 & 4,7 & 0,6 & 0,77 & \\
\hline 340 & 8 & 9 & 5 & 3,2 & 0,5 & 0,73 & \\
\hline 185 & 5 & 5,3 & 3,7 & 2,8 & 0,4 & 0,79 & \\
\hline 100 & 12 & 8,5 & 5,3 & 3 & 0,5 & 0,77 & \\
\hline 62 & 9 & 5 & 3,5 & 2,3 & 0,5 & 0,79 & \\
\hline 293 & 12 & 8,6 & 5,6 & 4,3 & 0,4 & 0,79 & \\
\hline 325 & 42 & 6 & 4,2 & 3 & 0,5 & 0,81 & \\
\hline 308 & 43 & 11 & 7 & 3,7 & 0,4 & 0,81 & \\
\hline 220 & 13 & 11,5 & 8 & 6 & 0,6 & 0,81 & \\
\hline
\end{tabular}


(Cont.)

\begin{tabular}{|c|c|c|c|c|c|c|c|}
\hline RUMO DE INCL. & ÂNG. DE INCL. & \multicolumn{2}{|c|}{ MED. DOS EIXOS (cm) } & & \multirow{2}{*}{ ARRED. } & ESFER. & LITOLOGIA \\
\hline Eixo longo (graus) & (graus) & $\mathbf{a}$ & $\mathbf{b}$ & $\mathbf{c}$ & & & \\
\hline 255 & 6 & 6,4 & 5,2 & 2,5 & 0,5 & 0,83 & \\
\hline 353 & 20 & 5 & 3,5 & 3 & 0,6 & 0,79 & \\
\hline 232 & 7 & 6,5 & 5 & 3,5 & 0,5 & 0,81 & \\
\hline 267 & 13 & 8,3 & 6 & 3,5 & 0,5 & 0,83 & \\
\hline 270 & 2 & 6 & 4,2 & 3 & 0,8 & 0,81 & \\
\hline 135 & 40 & 7,2 & 5 & 3 & 0,4 & 0,83 & \\
\hline 252 & 11 & 5,9 & 2,8 & 1,6 & 0,5 & 0,71 & \\
\hline
\end{tabular}

Tabela 3C: Medidas de orientação e características morfoscópicas dos seixos do leque aluvial Morretes - Ponto 21.2.92-01)

\begin{tabular}{|c|c|c|c|c|c|c|c|}
\hline \multirow{2}{*}{ RUMO DE INCL. } & ANG. DE NCL. & \multicolumn{2}{|c|}{ MED. DOS EXXOS (cm) } & \multirow{2}{*}{ ARRED. } & ESFER. & LITOLOGIA \\
\hline Eixo longo (graus) & (graus) & $\mathbf{a}$ & $\mathbf{b}$ & $\mathbf{c}$ & & & \\
\hline 315 & 10 & 11,9 & 9,9 & 6,3 & 0,4 & 0,87 & \\
\hline 315 & 12 & 7,5 & 5 & 3 & 0,4 & 0,77 & \\
\hline 15 & 20 & 7,4 & 3,5 & 2,9 & 0,6 & 0,71 & \\
\hline 43 & 10 & 9,7 & 7,2 & 4,8 & 0,6 & 0,83 & \\
\hline 243 & 5 & 8,4 & 5,2 & 4 & 0,5 & 0,73 & \\
\hline 107 & 2 & 4,7 & 3,6 & 2,8 & 0,7 & 0,77 & \\
\hline 72 & 8 & 7,5 & 3,5 & 3,3 & 0,4 & 0,71 & \\
\hline 204 & 5 & 8,5 & 5,6 & 4,1 & 0,4 & 0,81 & \\
\hline 155 & 12 & 12 & 6,7 & 5,3 & 0,5 & 0,77 & \\
\hline 316 & 23 & 7,2 & 5,8 & 2,1 & 0,5 & 0,83 & \\
\hline 0 & 7 & 6,8 & 4,6 & 3,2 & 0,6 & 0,87 & \\
\hline 133 & 10 & 8,1 & 5 & 2,3 & 0,4 & 0,83 & \\
\hline 27 & 18 & 6,6 & 4,3 & 2,6 & 0,5 & 0,81 & \\
\hline
\end{tabular}


(Cont)

\begin{tabular}{|c|c|c|c|c|c|c|c|}
\hline RUMO DE INCL. & ÂNG. DE INCL. & \multicolumn{2}{|c|}{ MED. DOS EIXOS (cm) } & \multirow{2}{*}{ ARRED. } & ESFER & LTTOLOGIA \\
\hline Eixo longo (graus) & (graus) & $\mathbf{a}$ & $\mathbf{b}$ & $\mathbf{c}$ & & & \\
\hline 333 & 18 & 6,8 & 5,6 & 2,8 & 0,4 & 0,79 & \\
\hline 313 & 9 & 12 & 10,1 & 6,7 & 0,5 & 0,81 & \\
\hline 316 & 13 & 8,9 & 5,2 & 3,5 & 0,4 & 0,77 & \\
\hline 18 & 22 & 7,7 & 4 & 3,2 & 0,6 & 0,71 & \\
\hline 41 & 13 & 10 & 7,1 & 4,5 & 0,4 & 0,81 & \\
\hline 245 & 7 & 8,7 & 5,6 & 4,3 & 0,4 & 0,83 & \\
\hline 335 & 19 & 7,3 & 5,9 & 3,1 & 0,5 & 0,73 & \\
\hline 25 & 21 & 6,4 & 4 & 2,5 & 0,6 & 0,87 & \\
\hline 136 & 9 & 9,1 & 6 & 2,7 & 0,5 & 0,77 & \\
\hline 2 & 12 & 7,3 & 4,9 & 3,5 & 0,5 & 0,81 & \\
\hline 317 & 21 & 7,6 & 6,2 & 2,4 & 0,4 & 0,82 & \\
\hline 168 & 12 & 10,5 & 6,2 & 5 & 0,5 & 0,83 & \\
\hline 217 & 8 & 9,4 & 6,5 & 4,8 & 0,6 & 0,85 & \\
\hline 109 & 12 & 5,3 & 4,2 & 3,7 & 0,5 & 0,75 & \\
\hline
\end{tabular}

